
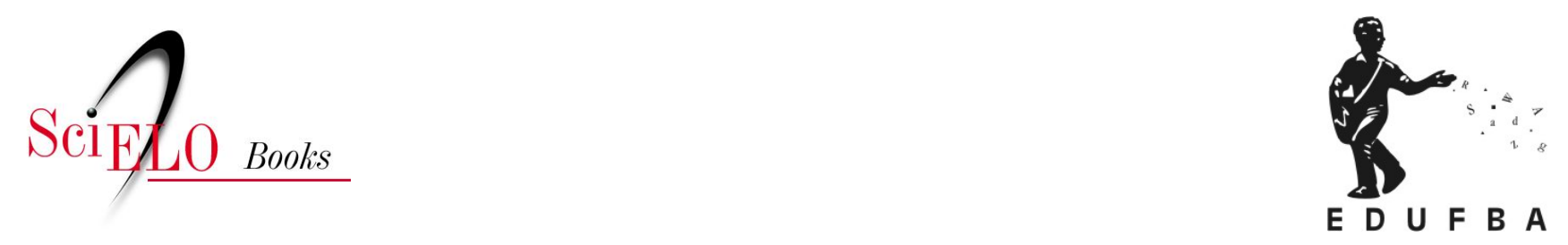

\title{
Gênero televisivo e modos de endereçamento no telejornalismo
}

\author{
Itania Maria Mota Gomes (org.)
}

SciELO Books / SciELO Livros / SciELO Libros

GOMES, IMM., org. Gênero televisivo e modos de endereçamento no telejornalismo [online]. Salvador: EDUFBA, 2011, 284 p. ISBN 978-85-232-1199-8. Available from SciELO Books $<$ http://books.scielo.org $>$.

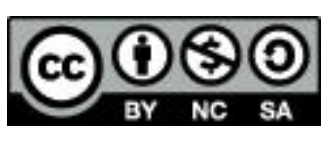

All the contents of this chapter, except where otherwise noted, is licensed under a Creative Commons Attribution-Non Commercial-ShareAlike 3.0 Unported.

Todo o conteúdo deste capítulo, exceto quando houver ressalva, é publicado sob a licença Creative Commons Atribuição - Uso Não Comercial - Partilha nos Mesmos Termos 3.0 Não adaptada.

Todo el contenido de este capítulo, excepto donde se indique lo contrario, está bajo licencia de la licencia Creative Commons Reconocimento-NoComercial-CompartirIgual 3.0 Unported. 
GÊNEROS TELEVISIVOS E MODOS DE ENDEREÇAMENTO NO TELEJORNALISMO 


\section{UNIVERSIDADE FEDERAL DA BAHIA}

\section{REITORA}

Dora Leal Rosa

VICE-REITOR

Luiz Rogério Bastos Leal

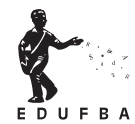

EDITORA DA UNIVERSIDADE FEDERAL DA BAHIA

DIRETORA

Flávia Goullart Mota Garcia Rosa

CONSELHO EDITORIAL

Titulares

Ângelo Szaniecki Perret Serpa

Caiuby Alves da Costa

Charbel Niño El-Hani

Dante Eustachio Lucchesi Ramacciotti

José Teixeira Cavalcante Filho

Alberto Brum Novaes

Suplente

Evelina de Carvalho Sá Hoisel

Cleise Furtado Mendes

Maria Vidal de Negreiros Camargo
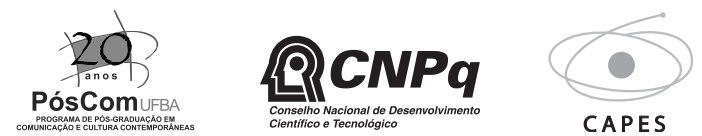
Itania Maria Mota Gomes

ORGANIZADORA

\section{GÊNEROS TELEVISIVOS E MODOS DE ENDEREÇAMENTO NO TELEJORNALISMO}

EDUFBA

Salvador, 2011 
@ 2011 by autor

Direitos para esta edição cedidos à EDUFBA

Feito o depósito legal

PROJETO GRÁFICO E EDITORAÇÃO ELETRÔNICA

Victor França e Matheus Menezes

CAPA

Rodrigo Oyarzábal Schlabitz

REVISÃO

Cida Ferraz

NORMALIZAÇÃO

Adriana Caxiado

Sistema de Bibliotecas - UFBA

Gênero televisivo e modo de endereçamento no telejornalismo / Itania Maria Mota Gomes, organizadora. - Salvador : EDUFBA, 2011.

$284 \mathrm{p}$.

ISBN 978-85-232-0797-7

1. Telejornalismo - Brasil. 2. Jornalismo - Brasil. I. Gomes, Itania Maria Mota.

CDD - 070.1950981

Editora filiada à:

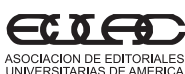

ASOCIACION DE EDITORIALES LATINA Y EL CARIBE
LARI

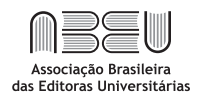

$\mathrm{CBaL}$

\section{EDUFBA}

Rua Barão de Jeremoabo, s/n Campus de Ondina

Salvador - Bahia CEP 40170-115 Tel/fax. 71 3283-6164

www.edufba.ufba.br

edufba@ufba.br 


\section{Sumário}

Apresentação 7

Metodologia de Análise de Telejornalismo 17

Itania Maria Mota Gomes

O Roda Viva e as estratégias de construção de um debate público 49

Fernanda Mauricio da Silva

Estratégias de endereçamento da primeira versão do Jornal da MTV 75 Juliana Freire Gutmann

Globo Rural: ao estilo da cultura do campo 101 Jussara Maia

Cidade Alerta: jornalismo policial, vigilância e violência 121 Dannilo Duarte Oliveira

O modo de endereçamento do Globo Repórter 151

Marília Hughes Guerreiro Costa

Infotainment na TV: as estratégias de endereçamento do Profissão Repórter 173

Thiago Emanoel Ferreira dos Santos

Telejornalismo na TV pública brasileira. Uma análise do Repórter Brasil 197 Valéria Vilas Bôas Araújo

O grito da cidade: Balanço Geral, qualidade e modos de endereçamento 223 Janira Borja

Jornal da Massa: jornalismo ou programa de humor? 243

Mirella Santos Freitas

É Fantástico! Gênero e modos de endereçamento no telejornalismo show 263

Luana Gomes

Sobre os autores 281 



\section{Apresentação}

Este livro é resultado de um esforço conjunto, realizado nos últimos 10 anos, de análise de programas jornalísticos televisivos, no âmbito do Grupo de Pesquisa em Análise de Telejornalismo, do Programa de Pós- Graduação em Comunicação e Cultura Contemporâneas. Ele toma como seu objeto a análise e interpretação de telejornalismo, a partir de dois conceitos metodológicos, o de gênero televisivo e o de modo de endereçamento, a partir de uma metodologia capaz de levar conta a linguagem televisiva em seus elementos textuais, visuais, sonoros; a configuração interna dos programas, de suas formas materiais, dos dispositivos técnicos, visuais e discursivos que organizam sua recepção.

O primeiro capítulo, Metodologia de Análise de Telejornalismo, apresenta os esforços de construção de um método de análise que se pretende válido e abrangente e que permita consolidar a análise e a interpretação de programas jornalísticos televisivos, a partir da perspectiva teórico- metodológica dos cultural studies, em associação com os estudos de linguagem, abordagem que implica a consideração de aspectos ao mesmo tempo históricos, sociais, ideológicos e culturais do telejornalismo. Essa abordagem nos permite articular três elementos fundamentais para a análise do telejornalismo, a saber, o jornalismo, a televisão e a recepção televisiva. Nessa proposta metodológica assumimos como premissa que o telejornalismo é uma forma cultural e uma instituição social, nos termos de Raymond Williams, e a partir dela articulamos os conceitos de estrutura de sentimento, gênero televisivo e modos de endereçamento, que são tomados como conceitos metodológicos, ou seja, como instrumentos para trabalhar materiais empíricos.

Estrutura de sentimento é um conceito que permite ao analista um olhar para o processo, para o modo como o telejornalismo é construído processualmente e, assim, acessar a emergência de novas características que ainda não se cristalizaram em ideologias, convenções, normas, 
fórmulas, g'êneros. O conceito de gênero televisivo permite compreender as regularidades e as especificidades em produtos que se configuram historicamente - ele permite dizer tanto do jornalismo como ideologia, valores, normas quanto das formas culturais historicamente dadas e, sobretudo, vincular nosso objeto de análise ao processo comunicacional - gênero televisivo é uma estratégia de comunicabilidade. Modo de endereçamento deverá permitir ao analista compreender como essas questões são atualizadas em um produto específico, objeto da análise. A partir dessas premissas e conceitos, desenvolvemos alguns operadores de análise dos modos de endereçamento: o mediador, o contexto comunicativo, o pacto sobre o papel do jornalismo e a organização temática.

Os capítulos seguintes constituem-se como exercícios de análise de telejornalismo a partir da aplicação da metodologia do Grupo. No Capítulo 2, O RODA VIVA e as estratégias de construção de um debate público, Fernanda Mauricio da Silva analisa as estratégias através das quais o Roda Viva, programa da TV Cultura, no ar desde 1986, realiza o ideal de fazer "jornalismo público de qualidade, ao oferecer aos telespectadores a possibilidade de conhecer o pensamento e o trabalho de personalidades nacionais e estrangeiras com profundidade". A promessa de um jornalismo de qualidade busca se concretizar por meio da proposta de reflexão e aprofundamento dos assuntos que o programa discute em seus cinco blocos de exibição e da permanente busca de inovação. Como programa de entrevistas há mais tempo em exibição no país, o Roda Viva pressiona o subgênero programa de entrevistas a partir de imbricações constantes com os programas de debates, já que é seu objetivo promover uma troca de ideias, opiniões e argumentos sobre os assuntos que concernem ao entrevistado e à sua área de atuação. O tempo prolongado, a performance dos participantes, o estatuto dos interlocutores em cena, os enquadramentos temáticos e a abertura para a interatividade com o público são marcas que parecem dar a tônica do modo de endereçamento do Roda Viva e justificam seu sucesso e longevidade na história televisiva nacional.

O Jornal da MTV, analisado no capítulo 3 por Juliana Freire Gutmann, é um produto televisivo voltado para uma especialização midiática: o jor- 
nalismo musical, e configura-se, portanto, como um programa de jornalismo temático. Junto com as publicações sobre música, revistas segmentadas, suplementos culturais dos jornais impressos, programas de rádio e sites especializados no assunto, o Jornal desempenharia o papel de publicizar e contextualizar artistas, bandas e cenas tendo em vista o significado cultural de tais produções. Estratégias de endereçamento da primeira versão do Jornal da MTV analisa o modo como a MTV adaptou o jornalismo musical, mais difundido na mídia impressa, às especificidades do ambiente televisivo. O entretenimento é um importante referencial para a relação que o Jornal da MTV busca construir com o espectador, uma vez que se insere no universo da música popular massiva, mas não é o principal elemento que configura seu pacto sobre o papel do jornalismo. No programa, o acordo proposto com o público sobre a função dessa especialização midiática é decisivamente marcado pelo ajuizamento de valor das bandas, cantores e suas manifestações. É esse pacto que assegura ao programa o lugar de formar a opinião dos ouvintes, orientando sobre "o que é bom" e "o que não é bom", contextualizando os artistas, gêneros e cenas.

No capítulo 4, Globo Rural: ao estilo da cultura do campo, Jussara Maia explora como os mediadores cumprem um papel fundamental na construção do modo de endereçamento do Globo Rural de domingo, reproduzindo com maior ou menor intensidade uma posição de proximidade, familiaridade, naturalidade e encantamento com os valores, tradições, procedimentos, processos, traços culturais e modo de vida do campo. A autora mostra como Nelson Araújo e José Hamilton Ribeiro conferem às suas participações, como repórteres e/ou apresentadores, marcas pessoais profundamente sintonizadas com a posição que o programa quer construir para a sua audiência. Nelson Araújo, por exemplo, acentua as marcas do diálogo e da linguagem oral com características marcadamente rurais. Como resultado desta escolha particular, o jornalista desenvolveu o chamado "cordel eletrônico", uma modalidade de texto telejornalístico que traduz, com clareza, suas intenções voltadas para a valorização de aspectos culturais, do modo de falar e de viver dos lugares onde são feitas as reportagens. 
Em Cidade Alerta: jornalismo policial, vigilância e violência, Dannilo Duarte Oliveira acompanha as transformações ocorridas no período de 2004 e 2005 no programa veiculado pela TV Record, buscando compreender como o programa se configura na articulação entre dois subgêneros da programação jornalística, o telejornal e o programa temático. O Cidade Alerta, com sua ênfase na produção de notícias sobre violência urbana, polícia e segurança, com uma cobertura marcadamente sensacionalista, apresenta-se como um telejornal policial. A vinheta, o cenário, as cores, os enquadramentos de câmera, a performance cênica do apresentador e suas estratégias verbais de interpelação da audiência, o bom relacionamento construído com o meio policial, o que lhe garante vários "furos" e a possibilidade de acompanhar e transmitir ao vivo ações policiais, algumas delas programadas para acontecer no horário da transmissão do programa, são aspectos que, articulados no Cidade Alerta, constroem para o programa um lugar de juiz da sociedade: seja substituindo ou tentando substituir as instituições do judiciário, seja assumindo o papel do próprio Estado, que controla e disciplina os desvios sociais, o Cidade Alerta propõe um pacto com a audiência de um jornalismo de vigilância, denúncia e prestação de serviço. A relação que constrói com a audiência diz que ele está ali, vigilante, alerta, pronto a denunciar as falhas dos sistemas públicos e a alertar a sociedade sobre os riscos a que está sujeita.

No capítulo 6, Marília Hughes Guerreiro Costa analisa um dos programas mais emblemáticos do telejornalismo brasileiro e também um dos mais antigos ainda em exibição na grade de oferta televisiva atual. O Globo Repórter, que teve sua primeira transmissão em abril de 1973, só perde, em tempo de duração na grade da TV aberta brasileira para o Jornal Nacional, da mesma emissora, a TV Globo. Para compreender O modo de endereçamento do Globo Repórter, a autora faz uma avaliação histórica do programa, tomando em análise três momentos distintos: os anos iniciais, na década de 70; os anos 80, que marcam uma série de alterações técnicas, econômicas e de linguagem; e o ano de 2008, percorrendo um período de 35 anos de programa. O Globo Repórter tem seus anos iniciais marcados pela colaboração de vários cineastas, a maioria deles vindos de uma experiência com o Cinema Novo, o que represen- 
tou uma aproximação pioneira entre o cinema, o cinema documentário e a televisão, num processo que foi decisivo para a configuração de uma linguagem propriamente televisiva no Brasil. Dez anos depois, em 1983, o suporte é mudado de filme para vídeo, o que altera o processo de trabalho e possibilita um maior controle da Rede Globo, não apenas sobre os conteúdos, mas também sobre a forma. É nesse estágio que os repórteres ganham força, em detrimento dos cineastas. A Rede Globo passa a controlar inteiramente a produção do Globo Repórter, que fica, então, sob a responsabilidade de uma equipe de profissionais contratados pela emissora, em sua maioria, formada por jornalistas. O ano de 1983, portanto, representa uma linha divisória que marca a transição pela qual passou o programa. Mais recentemente, o Globo Repórter é certamente um programa que investe na credibilidade da informação, seja através da presença constante de especialistas ou do repórter, que é valorizado como testemunha do acontecimento. Mas a credibilidade da informação negocia permanentemente com o uso de recursos narrativos e de atração para chamar a atenção do telespectador. Portanto, a informação ganha contornos de algo surpreendente, inédito, fascinante, espetacular. O programa faz uso de estratégias, formas e retóricas para provocar excitação, drama, espetáculo e fascínio, constituindo-se como um dos modos de articular informação e entretenimento.

O Globo Repórter, visto numa perspectiva histórica, substituiu um modelo mais próximo do cinema e caminhou em direção à consolidação de um formato de documentário televisivo e jornalístico, que se tornou padrão na Rede Globo. Esse padrão, por sua vez, permite falar de um modo de tratamento dos temas que independe do diretor ou mesmo do conteúdo do programa. A análise da trajetória do Globo Repórter permite compreender como a televisão brasileira foi configurando um modo específico de fazer jornalismo na TV e, nesse processo, configurando expectativas dos telespectadores em relação ao programa e em relação ao gênero jornalismo televisivo. Nesses 35 anos, o Globo Repórter foi construindo um modo de endereçamento que se consolidou na passagem do 
documentário televisivo ao programa de grande reportagem e, daí, à articulação entre reportagem e entretenimento.

A relação entre jornalismo e entretenimento também é o tema central da análise que Thiago Emanoel Ferreira dos Santos faz do Profissão Repórter, da Rede Globo, mas, nesse caso, o operador de análise dos mediadores é o que mais se destaca na organização do modo de endereçamento do programa. O capítulo 7, Infotainment na TV: as estratégias de endereçamento do Profissão Repórter, mostra como o programa articula três modos de comunicação possíveis no telejornalismo contemporâneo informação, storytelling e atrações. Apresentar "Os bastidores da notícia. Os desafios da reportagem”, no Profissão Repórter, só é possível, para a TV Globo, através de uma estratégia em que um jornalista experiente coordena as atividades de jornalistas jovens. A trajetória profissional de Caco Barcellos é permanentemente convocada pelo programa em contraposição aos chamados jovens repórteres. Barcellos é o editor, apresentador e narrador principal do programa, o jornalista experiente que explica aos repórteres mais novos os elementos das reportagens e edita o que eles fizeram durante o processo de apuração. A posição do jornalista experiente é a posição séria, de condução, de domínio do código do jornalismo, do habitus, cabendo aos jovens jornalistas o espaço da experimentação, da emoção, do erro, da inexperiência, da ousadia, da aprendizagem. Ferreira dos Santos nos mostra que as estratégias utilizadas permitem ao programa construir em torno de si uma função metalinguística do jornalismo, em que os jornalistas explicam as suas práticas profissionais no decorrer da produção das histórias ali relatadas, com Barcellos sendo a figura que assume, retoricamente, a posição do sujeito que explica para os telespectadores os bastidores e os desafios de se fazer uma reportagem na televisão.

A primeira produção jornalística da TV Brasil, a emissora pública criada pelo governo Lula é analisada por Valéria Vilas Bôas Araújo. Telejornalismo na TV pública brasileira. Uma análise do Repórter Brasil, capítulo 8, toma o programa que teve sua primeira transmissão no dia 03 de dezembro de 2007 e busca compreender como "mostrar o país que traz no nome, de um jeito como ele não é visto nas emissoras comerciais", 
objetivo da Empresa Brasil de Comunicação (EBC) para o telejornal, se articula com as noções de cidadania, interesse público e identidade nacional. A autora nos mostra que apesar da proposta declarada de fazer um jornalismo "nacional de fato", o enfoque predominante do noticiário é o do eixo Rio-São Paulo-Brasília, porque a apresentação do telejornal é feita a partir destas três cidades e, sobretudo, porque as matérias de âmbito "nacional" são geralmente elaboradas a partir de um exemplo generalizado original destes centros simbólicos; que o interesse público é construído através do recurso às fontes oficiais, institucionais, especializadas; que política parece construída como algo exterior ao cotidiano das pessoas; que, ainda que busque notícias sobre acontecimentos que tenham influência na vida do cidadão, este é, no mais das vezes, apenas uma ilustração ou exemplo nas matérias, sua participação no programa é quase restrita a espaços bem demarcados dentro do noticiário, como, por exemplo, nas enquetes. No entanto, na tentativa de abrir maior espaço para a participação do cidadão e para cumprir a obrigação, prevista em Lei, de estimular e exibir produção independente no horário noturno, o Repórter Brasil criou o quadro Outro Olhar, que exibe vídeos produzidos pela população e selecionados pela equipe do jornal, uma experiência interessante de jornalismo participativo na televisão e talvez o mais significativo momento de experimentação dentro do telejornal.

A defesa dos interesses do cidadão também é a promessa contida no programa analisado no capítulo 9, O grito da cidade: Balanço Geral, qualidade e modos de endereçamento, de Janira Borja, mas nesse caso, através de um programa de jornalismo local da televisão na Bahia, o Balanço Geral, veiculado pela TV Itapoan (retransmissora da TV Record na Bahia), desde meados dos anos 80 . O programa apresenta um formato tão bem sucedido que a Rede Record decidiu exportá-lo para outras praças a partir de 2003. Borja analisa o programa baiano, tomando como base emissões do mês de setembro de 2006, explorando as potencialidades da análise de modos de endereçamento para análise da qualidade televisiva. Seu intuito é partir de uma avaliação do programa, considerado em suas especificidades como produto telejornalístico, e evitar partir do julgamento ético, moral, político, estético que guia a maior parte das abor- 
dagens sobre programas populares. A análise da qualidade a partir dos modos de endereçamento deverá responderá a perguntas tais como: o telejornal consegue organizar seus elementos internos de modo a estabelecer um clara relação comunicativa com seu telespectador? O modo de endereçamento, que diz dessa relação com a audiência, funciona em acordo, ou seja, ele consegue utilizar corretamente os elementos da linguagem televisiva e do gênero jornalístico a fim de atrair esse telespectador? O mediador foi o principal operador de análise, já que é a partir dele que o programa se estrutura.

Ainda outro programa de jornalismo popular é analisado neste livro, o Jornal da Massa, apresentado por Carlos Massa, o Ratinho, e exibido pelo SBT a partir de janeiro de 2007. O programa substitui o Programa do Ratinho, alvo de críticas pesadas de entidades da sociedade civil. A presença do humor no programa, aliada a alguns depoimentos divulgados na imprensa, bem como ao posicionamento do próprio apresentador Carlos Massa, levaram a autora ao questionamento central do capítulo -Jornal da Massa: jornalismo ou programa de humor?, problematizando o gênero televisivo em que o programa se inscreve. Para Mirella Santos Freitas, o fim do programa, menos de um ano depois da sua estreia, devido, principalmente, à baixa audiência, pode ser explicado, ao menos em parte, como consequência da sua indefinição quanto ao gênero ou ao modo pouco competente de articular jornalismo e humor. O desencontro de opiniões e posicionamentos por parte dos seus produtores acerca do gênero do programa pode ter comprometido a construção de uma relação de credibilidade entre o programa, enquanto telejornal, e a sua audiência.

No último capítulo, É Fantástico! Gênero e modo de endereçamento no telejornalismo show, Luana Gomes avalia como o Fantástico, em exibição desde 1973, realiza sua proposta inovadora, para aquela época, de "misturar jornalismo e entretenimento de forma dinâmica e acessível", e, ao fazê-lo, constitui as marcas do próprio subgênero revista eletrônica. O Fantástico constrói um modo de endereçamento em que a relação comunicativa com os telespectadores é construída, duplamente, através da alimentação da conversação social e do entretenimento. Seu caráter informativo, de relatar os acontecimentos mais importantes da semana, 
é conformado com o objetivo de alimentar a conversação cotidiana, com vistas à formação da opinião pública sobre a realidade social. Por outro lado, em função da variabilidade de formatos de construção televisiva e da variedade do conteúdo apresentado, dentro de um contexto marcado pela descontração e leveza, o compromisso com o entretenimento é constantemente verificado.

Em sua diversidade, os capítulos representam nossos esforços constantes para desenvolver métodos de análise adequados para os produtos televisivos/telejornalísticos, que os considerem em sua especificidade. Este livro não se configura como um manual de telejornalismo. Não há aqui receitas de qualquer espécie, seja para a elaboração de produtos, seja para a análise de telejornalismo. Nosso objetivo foi, efetivamente, testar a metodologia proposta, submetendo-a à análise de diferentes produtos da grade da televisão aberta no Brasil, e, assim, avaliar suas potencialidades.

O projeto de pesquisa Gênero Televisivo e Modo de Endereçamento no Telejornalismo foi realizado com bolsa de Produtividade em Pesquisa do CNPq, no período de março de 2005 a fevereiro de 2008, e permitiu, em suas diversas etapas, a consolidação de uma metodologia de análise de telejornalismo e a consolidação, também, do Grupo de Pesquisa em Análise de Telejornalismo, que completa, em 2011, 10 anos de trabalho. Estão diretamente relacionadas à realização do projeto, a criação e atualização permanente do site do Grupo de Pesquisa em Análise de Telejornalismo (www.telejornalismo.facom.ufba.br), onde estão disponíveis, em acesso livre, toda a produção científica, os cursos e as atividades de extensão realizadas, além de críticas cotidianas de programas telejornalísticos. Agradeço a todos os autores pela colaboração e ao PósCom/UFBA pelo apoio para a publicação deste livro.

Salvador, março de 2011.

Itania Maria Mota Gomes

(Organizadora) 



\title{
Metodologia de Análise de Telejornalismo ${ }^{1}$
}

\author{
Itania Maria Mota Gomes
}

\section{INTRODUÇÃO}

A importância que a televisão assume no Brasil ainda não produziu, como resultado, o desenvolvimento de métodos de análise adequados de seus produtos. O mais frequente é que a televisão seja tomada a partir de abordagens mais gerais, macroeconômicas, históricas ou sociais, e que o programa televisivo, enquanto um produto cultural com certas especificidades, seja deixado de lado. Na maior parte dos casos, os estudos que tomam a televisão como seu objeto de investigação, ainda que considerem seus produtos, tendem a se dispersar em direção a outros objetos de análise, afastando-se da análise dos programas efetivamente produzidos e veiculados. No caso do telejornalismo, a situação parece se agravar. Tais estudos têm o mérito de reconhecer a televisão como objeto de interesse científico e de produzir conhecimento relevante sobre a televisão no Brasil, em especial quanto ao seu caráter histórico, social e econômico, mas a pouca ênfase nos produtos televisivos, tomados eles mesmos como objeto empírico, tem resultado numa certa fragilidade teórica e metodológica, quando se trata de descrever, analisar, interpretar os modos de funcionamento, as especificidades, as características do programa televisivo $^{2}$.

1 Este capítulo é resultado do projeto Gênero Televisivo e Modo de Endereçamento no Telejornalismo, financiado pelo Conselho Nacional de Desenvolvimento Científico e Tecnológico/ CNPq, com bolsa de produtividade em pesquisa, modalidade 2, no período de março de 2005 a fevereiro de 2008. Uma versão resumida foi publicada em Gomes (2007).

2 No Brasil, algumas exceções são os trabalhos de Vera França, Elizabeth Bastos Duarte, Arlindo Machado, Immacolata Lopes, Maria Carmem Jacob de Souza, João Freire. Em texto recente, Arlindo Machado discute as condições de análise da televisão, chamando a atenção para a necessidade do exame concreto dos programas televisivos. (MACHADO; VÉLEZ, 2007) 
Este capítulo tem como ambição apresentar nossas primeiras tentativas de construção de um método de análise válido e abrangente, que permita consolidar a análise e a interpretação de programas jornalísticos televisivos, a partir da perspectiva teórico-metodológica dos cultural studies, em associação com os estudos de linguagem, abordagem que implica a consideração de aspectos ao mesmo tempo históricos, sociais, ideológicos e culturais do telejornalismo. Essa abordagem nos permite articular três elementos fundamentais para a análise do telejornalismo, a saber, o jornalismo, a televisão e a recepção televisiva. Nessa proposta metodológica ainda em desenvolvimento, assumimos como premissa que o telejornalismo é uma forma cultural e uma instituição social, nos termos de Raymond Williams. A partir dessas premissas, articulamos os conceitos de estrutura de sentimento, gênero televisivo e modos de endereçamento, que são aqui tomados como conceitos metodológicos, ou seja, como instrumentos para trabalhar materiais empíricos.

Estrutura de sentimento é um conceito que permite ao analista um olhar para o processo, para o modo como o telejornalismo é construído processualmente e, assim, acessar a emergência de novas características que ainda não se cristalizaram em ideologias, convenções, normas, fórmulas, gêeneros. O conceito de gênero televisivo permite compreender as regularidades e as especificidades em produtos que se configuram historicamente - ele permite dizer tanto do jornalismo como ideologia, valores, normas quanto das formas culturais historicamente dadas e, sobretudo, vincular nosso objeto de análise ao processo comunicacional - gênero televisivo é uma estratégia de comunicabilidade. Modo de endereçamento deverá permitir ao analista compreender como essas questões são atualizadas em um produto específico, objeto da análise. A partir dessas premissas e conceitos, desenvolvemos alguns operadores de análise dos modos de endereçamento.

PREMISSAS: O TELEJORNALISMO COMO INSTITUIÇÃO SOCIAL E COMO FORMA CULTURAL

Considerar o telejornalismo na perspectiva dos estudos culturais deve implicar articular suas dimensões técnica, social e cultural, o que garante 
unidade ao nosso objeto de estudo e um olhar mais atento ao analista. Do nosso ponto de vista, isso significa acompanhar Raymond Williams (1997, p. 22), para quem a televisão é, ao mesmo tempo, uma tecnologia e uma forma cultural, e o jornalismo, uma instituição social ${ }^{3}$. O telejornalismo é, então, uma construção social, no sentido de que se desenvolve numa formação econômica, social, cultural particular e cumpre funções fundamentais nessa formação. A concepção de que o jornalismo tem como função institucional tornar a informação publicamente disponível e de que o faz através das várias organizações jornalísticas é uma construção: é da ordem da cultura o jornalismo ter se desenvolvido deste modo em sociedades específicas. Michael Schudson (1978), numa análise histórica da imprensa norte-americana, e em especial do conceito de objetividade, evidencia como o jornalismo vai se construindo como instituição social específica em relação com o contexto histórico, social, econômico dos Estados Unidos. Por exemplo, antes de 1830 a objetividade não era uma premissa. O mesmo autor dirá, poucos anos mais tarde, que as notícias são convenções:

As convenções ajudam a tornar as mensagens legíveis. Elas fazem- no de uma maneira que se adapta ao mundo social dos leitores e escritores, porque as convenções de uma sociedade ou tempo não são as mesmas de outra altura diferente. (SCHUDSON, 1993, p. 280)

O telejornalismo, como instituição social, não se configura somente a partir das possibilidades tecnológicas oferecidas, mas na conjunção das possibilidades tecnológicas com determinadas condições históricas, so-

3 Para Williams (1971, p. 118), as instituições são um dos três aspectos de todo processo cultural, junto com as tradições e as formações. Ali, os meios de comunicação aparecem, junto com a família, a escola, a igreja, certas comunidades e locais de trabalho, como instituições que exercem poderosas pressões sobre o modo de vida, "ensinam, confirmam e, na maioria dos casos, finalmente impõem significados, valores e atividades". No entanto, não é possível dissociar a análise das instituições da análise das tradições (“a expressão mais evidente das pressões e limites dominantes e hegemônicos”) e das formações (esses movimentos e tendências efetivos que têm significativa influência no desenvolvimento ativo de uma cultura). Nesse sentido, as instituições seriam, então - e no sentido que esses termos adquirem no pensamento de Raymond Williams - constituídas e constituintes e devem ser pensadas na relação com as tradições e formações. 
ciais, econômicas e culturais. Isso de modo algum significa conceber o jornalismo como cristalização, mas, bem ao contrário, afirmar seu caráter de processo histórico e cultural. Para o desenvolvimento de uma metodologia de análise, essa premissa obriga uma atenção às diferenças existentes entre as diversas sociedades e tempos históricos e seus jornalismos - do ponto de vista dos seus valores e convenções; do ponto de vista das formas do gênero.

Afirmar o telejornalismo como uma construção, no entanto, e justamente por esta razão, não nos impede de reconhecer que ele se configura como uma instituição social de certo tipo nas sociedades ocidentais contemporâneas. No Brasil, em que o jornalismo supostamente reproduziria o modelo de jornalismo independente estadunidense, pensar o jornalismo como instituição social requer colocar em causa a relação entre jornalismo e a noção habermasiana de esfera pública ${ }^{4}$, com suas implicações sobre a noção de debate público e vigilância pública; a perspectiva liberal sobre o papel democrático da mídia; a noção de quarto poder, em que está implícita a autonomia da imprensa em relação ao governo, o direito à liberdade de expressão e o compromisso com o interesse público; o caráter público ou privado da empresa jornalística.

Pensando sobre as consequências do "dilúvio comercial" sobre o sistema midiático europeu, Blumler e Gurevitch (1995) partem da teoria da democracia, pensada aos moldes da democracia representativa, para descrever as funções e serviços que os media cumpririam no sistema político. Para esses autores, os media teriam por função: a vigilância sobre o sistema social e político; o estabelecimento de uma agenda pública; a disponibilização de uma plataforma para a defesa esclarecida de causas e interesses de grupos; o diálogo entre diferentes pontos de vista e entre esses pontos de vista e o público massivo; mecanismos de prestação de contas para quem exerce o poder público; incentivos para que os cidadãos aprendam, escolham e se envolvam com o processo político; resistência aos efeitos das forças externas aos media, para subverter sua independência, integridade e capacidade de servir ao interesse público;

4 Ver Itania Gomes e outros (2004); Wilson Gomes (1998, 2009); Jensen, (1986). 
e respeito pelos membros da audiência como preocupados e capazes de compreender seu ambiente político.

Essas funções e serviços implicam também uma específica concepção de notícia ou de informação jornalística. É nesse modelo de jornalismo que as noções de imparcialidade e objetividade fazem sentido. É neste modelo de jornalismo que as distinções entre fato e ficção, informação e entretenimento tornam-se úteis. É claro que, na nossa concepção, a notícia é uma construção e não uma representação "fiel” da realidade. As noções de objetividade e imparcialidade no jornalismo são mais apropriadas a uma concepção empiricista da realidade que está fora do enquadramento da nossa perspectiva teórica. É certo que a objetividade é construída e tem uma hereditariedade comercial (SCHUDSON, 1978; DAYAN, 2005), entretanto, ambas as noções são úteis na análise porque enquadram o modo como o jornalismo é socialmente aceito, e regulam, pelo menos retoricamente, as ações profissionais e as expectativas do público.

Chamamos a atenção de que essas premissas sobre o jornalismo precisam ser analisadas em relação ao contexto profissional e cultural em que a prática jornalística acontece. Embora, em termos gerais, possamos imaginar que certos cânones e expectativas sejam próprios de sociedades ocidentais contemporâneas, há diferenças marcantes em relação à história do jornalismo e dos media em cada contexto específico (por exemplo, para indicar apenas as mais discutidas, as diferenças entre os modelos inglês e estadunidense ou entre os modelos estadunidense e francês de televisão e de jornalismo) e de modo algum concordamos que não haja diferenças - de práticas, de sistema, de ideologia - no jornalismo realizado em distintos períodos históricos e distintas sociedades. Até certo ponto, muitos dos valores e normas profissionais adotados pelos jornalistas em países democráticos são made in the USA. No entanto, devemos nos perguntar como esses valores e normas são efetivamente desenvolvidos nas atividades profissionais específicas e como eles configuram produtos comunicacionais específicos em diferentes contextos ${ }^{5}$.

5 Afonso de Albuquerque (1999, p. 9) analisa a influência do modelo jornalístico estadunidense sobre o jornalismo brasileiro e chama a atenção para o fato de que os diferentes ambientes político e cultural em que os dois jornalismos se configuram deveriam fazer supor que o modelo 
Do nosso ponto de vista, um dos principais desafios da investigação sobre o jornalismo contemporâneo é compreender como duas questões centrais do nosso século, a tecnologia digital e o multiculturalismo ou, se quisermos dizer de outro modo, os largos processos de globalização e os fluxos migratórios, interagem com o jornalismo e que implicações têm sobre o jornalismo enquanto uma atividade social, enquanto ideologia e enquanto campo profissional. Do ponto de vista dos valores que constituem o jornalismo como instituição social, é fundamental interrogar como se dá a conjunção entre jornalismo, sociedade e cultura, como essa conjunção interage com e reconfigura certos valores jornalísticos tomados como universais: interesse público, objetividade, atualidade, credibilidade, independência, legitimidade ${ }^{6}$.

Interesse público, por exemplo, é um dos principais valores jornalísticos. Ele parece regular a prática profissional e a ele se recorre para arg’umentar a favor da própria legitimidade do jornalismo. Não seria o caso de perguntarmos se a diversidade cultural, no modo como ela é vivenciada atualmente no contexto europeu, para falarmos de apenas um exemplo em que essa situação é mais evidente, não implicaria uma modificação na noção de interesse público nessas sociedades? A questão da imigração - a relação com as identidades culturais, mas também com o desemprego e a violência - tem aparecido no centro de várias disputas políticas (na Inglaterra, na França, na Itália, na Alemanha, na Espanha), mas tem implicado também uma redefinição do jornalismo em direção ao reconhecimento da diversidade cultural nesses países ou, quando menos, um recrudescimento da crítica ao modo como os jornalistas e os veículos enquadram a diferença cultural. De todo modo, isso parece demandar um olhar culturalmente mais diversificado, com implicações sobre o proces-

de jornalismo efetivamente praticado também difere. Segundo o autor, é de se supor que a adesão dos jornalistas brasileiros aos princípios do jornalismo estadunidense "é antes de tudo um gesto formal; na prática, os jornalistas brasileiros tendem a interpretar esses princípios e a definir o seu compromisso político de maneira muito diferente dos seus colegas americanos".

6 Mark Deuze (2005) realiza um interessante estudo sobre as implicações das novas tecnologias e da diversidade cultural sobre a configuração da ideologia jornalística, indicando sutis e lentas transformações na concepção dos valores de interesse público, objetividade, imediaticidade, autonomia e ética. 
so de decisão editorial ${ }^{7}$. A importância dos processos de globalização e da diversidade cultural para o jornalismo diz respeito ao conhecimento que os jornalistas têm ou precisarão ter sobre as diferentes culturas e etnias, às questões da representação e, particularmente, à percepção da responsabilidade social dos jornalistas - e do jornalismo como instituição - em sociedades democráticas e multiculturais. (DEUZE, 2005)

Ao mesmo tempo em que a convergência tecnológica implica uma reorganização do processo de produção jornalística, com consequências sobre o que costumamos chamar de cultura jornalística, as tecnologias digitais têm favorecido, senão o surgimento, a consolidação do jornalismo de tipo cidadão, com a proliferação dos recursos de interatividade, dos blogs, chats, do jornalismo open source e de sites de disponibilização de vídeos que tendem a reconfigurar os valores jornalísticos e a relação entre jornalismo e público. No caso específico do telejornalismo, verificamos, por exemplo, que cada vez mais as grandes emissoras têm utilizado imagens de amadores, em particular de filmes produzidos com telefones celulares - imagens, portanto, que não seguem quaisquer dos critérios profissionais de controle e verificação da informação - como modo justamente de ampliar a autenticidade e a veracidade dos programas telejornalísticos.

De modo imbricado com suas configurações como instituição social, o jornalismo se configura também como uma forma cultural. No caso do telejornalismo, acreditamos que, para entendê-lo, é preciso compreender a notícia como uma forma cultural específica de lidar com a informação e o programa jornalístico televisivo como uma forma cultural específica de lidar com a notícia na TV. Em outros termos, cremos que, apesar de ser um gênero fortemente codificado, se sua história tivesse sido outra, o telejornal poderia ter hoje outro formato. (MACHADO, 2000,

7 Berkowitz; Limor e Singer (2004, p. 164) propõem um olhar intercultural sobre a noção de interesse público e estudam como jornalistas estadunidenses e israelenses se comportam em relação a determinadas questões éticas relativas à prática profissional. Segundo os autores, "as diferenças nacionais fortes parecem impossibilitar todas as percepções ou valores jornalísticos universais". 
p. 105) Abordaremos a notícia como um gênero do discurso e o programa jornalístico televisivo como um gênero midiático.

A notícia é discurso e, como tal, um conjunto de convenções que ajudou a configurar o jornalismo como uma instituição socialmente reconhecida e no interior da qual fazem sentido as noções de imparcialidade e objetividade e as distinções entre fato e ficção, informação e entretenimento. Naturalmente, a notícia televisiva é um discurso que é estruturado pelos discursos mais amplos da televisão. A notícia, seja ela ouvida no rádio, lida nos jornais ou vista na televisão, ganha muito de sua configuração das características do próprio meio no qual ela aparece. Daí a importância de analisarmos as configurações da notícia como um gênero discursivo em relação às características que ela ganha quando elaborada para transmissão na televisão.

Ainda nos anos 70, Paul H. Weaver (1993, p. 295) se preocupou com as semelhanças e diferenças entre as notícias de jornal e as notícias de televisão, do ponto de vista da sua natureza, dos seus pressupostos e de suas consequências políticas. Para o autor, "a notícia é um gênero, um modo distinto de escrever e relatar experiências" (WEAVER, 1993, p. 295) ${ }^{8}$, mas esse gênero apresenta "variantes", quer se trate de imprensa ou de televisão. Então, é necessário considerar, ao mesmo tempo, as semelhanças - é preciso reconhecer que se trata de um mesmo fenômeno, a notícia ou o jornalismo - e as diferenças - de natureza, princípios, forma em função dos diferentes suportes e das diferentes linguagens utilizadas.

Fazendo a ressalva de que as suas hipóteses se referem aos jornais e televisão norte-americanos ${ }^{9}$, Weaver (1993, p. 295) considera que as notícias de jornal e de televisão são semelhantes no sentido de que são variedades de jornalismo, “[...] o que significa que ambos consistem num relato actual de acontecimentos actuais"; no sentido de que constroem sua cobertura dos acontecimentos "[...] por meio da reportagem, isto é, a descrição factual daquilo que um observador em cima do acontecimen-

8 O artigo foi originalmente publicado em 1975.

9 Já que, para o autor, “deve-se olhar para o jornalismo num dado lugar e num tempo determinado. As diferenças nacionais e históricas dentro do jornalismo são extremamente grandes”. (WEAVER, 1993, p. 295) 
to em questão viu e ouviu" (WEAVER, 1993, p. 295); no sentido de que os relatos "[...] são vocacionalmente produzidos por organizações com objectivos especiais" (WEAVER, 1993, p. 296); e no sentido de que utilizam os mesmos "temas, fórmulas e símbolos na construção de linhas de acção dramática que dão significado e identidade aos acontecimentos". (WEAVER, 1993, p. 296)

Ao mesmo tempo, as notícias de jornal e as notícias de televisão apresentam distinções elementares do ponto de vista da "estrutura, voz e conteúdo". Quanto à estrutura, a diferença estaria “[...] associada ao facto de a televisão estar organizada e apresentada no tempo, enquanto a edição do jornal está apenas organizada no espaço" (WEAVER, 1993, p. 297), com consequências sobre o modo de organização da oferta das notícias aos leitores e telespectadores, sobre a sua configuração textual (para o autor, a notícia de televisão é uma forma muito mais flexível e intelectualmente moldável do que a do jornal (WEAVER, 1993, p. 299), sobre o modo de interpretar os acontecimentos e sobre as formas de controle do processo de produção jornalístico. As notícias de jornal e as notícias televisivas teriam diferenças também nos seus modos de construção narrativa, consequência do fato de que a notícia de televisão é ao mesmo tempo visual e auditiva, enquanto a de jornal seria apenas visual (WEAVER, 1993, p. 300) - para o autor, isso implicaria um narrador impessoal para o jornal e um narrador pessoal e onisciente no jornalismo de TV (na televisão, ouve-se a voz, vê-se o corpo e a postura da pessoa que fala). Finalmente, “[...] a notícia televisiva difere da notícia do jornal na muito maior importância que a televisão dá ao espetáculo” (WEAVER, 1993, p. 303), consequência de poder usar a imagem e o som e consequência de os jornalistas de televisão americanos se empenharem em enfatizar essa especialidade, empenho que se traduz pelo cuidado com a imagem (em detrimento, segundo o autor, dos aspectos mais propriamente jornalísticos) e com a dramatização.

Um outro autor que se ocupa da caracterização da notícia como um gênero é Klaus Bruhn Jensen (1986, p. 50), que entende que

[...] um gênero é uma forma cultural que apresenta a realidade social em uma perspectiva própria e, ao fazer isso, implica formas es- 
pecíficas de percepção e usos sociais do conteúdo. Assim, o gênero estabelece um modo de comunicação ou, mais especificamente, uma situação comunicativa, entre o emissor e o destinatário.

Seguindo Raymond Williams (1979), Jensen propõe que a definição da notícia como um discurso leve em conta três aspectos, a posição, o assunto adequado e o modo de composição formal ${ }^{10}$.

Com posição do autor em relação ao seu material os autores se referem a um modo de organização básica que determina um tipo particular de apresentação dos conteúdos. A posição tem a ver não apenas com o modo como o autor aborda um tema, mas também com os objetivos retóricos daquela abordagem em relação à audiência. O que o conceito de posição enfatiza é que qualquer texto é sempre uma comunicação socialmente situada.

No caso do gênero notícia, a posição que é projetada enfatiza o papel do jornalista como um observador independente, sua apuração dos fatos sociais, a contraposição de pontos de vista e assim por diante. Simultaneamente, o leitor/telespectador é posicionado como um receptor de informações reais, confiáveis, presumivelmente relevantes num sentido político mais amplo. (JENSEN, 1986, p. 50)

O tema apropriado de diferentes gêneros varia enormemente. O tema do gênero notícia, por exemplo, no modelo de jornalismo anglo-saxônico, deriva da noção de esfera pública e sua implícita separação das esferas sociais. Por outro lado, a notícia tem, também, um modo de composição formal característico. Por exemplo: cabeça - off - passagem - sonoras e nota pé, se pensarmos na organização mais clássica da matéria televisiva no Brasil. De todo modo, o que importa aqui é que a posição, o assunto adequado e o modo de composição formal da notícia como um gênero são configurados historicamente.

10 Williams e Jensen falam em stance, the appropriate subject matter e mode of formal composition. Aqui adotamos os termos tal como apresentados na tradução de Marxismo e literatura, publicado no Brasil pela Zahar. 
No telejornalismo, o componente da imagem faz muita diferença. Jensen coloca ênfase na questão da credibilidade, de como as imagens da cobertura televisiva reforçam a expectativa de objetividade e imparcialidade, e nas convenções jornalísticas que regulam a imagem jornalística. A variedade de imagens oferecidas aparece também como um forte apelo para a audiência e, de modo a manter o telespectador preso no fluxo televisivo, no telejornalismo as imagens são estruturadas de acordo com a estética de produção de mercadoria. Além disso,

[...] em princípio, o gênero notícia televisiva expõe duas narrativas paralelas: a narrativa visual, que se coloca como um documento do que realmente aconteceu, assim demonstrando a pretensão da objetividade, e a narrativa falada que contribui com informação complementar, ainda que permaneça relativamente distinta, sem comprometer o status da narrativa visual como pura informação. Para a audiência, essa convenção de gênero contribui para a potencial heterogeneidade da experiência com o jornalismo. Qualquer que seja sua justificação econômica ou organizacional, a convenção resulta numa estrutura de mensagem que é relativamente aberta a um leque de interpretações. (JENSEN, 1986, p. 65)

OS CONCEITOS: ESTRUTURA DE SENTIMENTO, GÊNERO TELEVISIVO E MODO DE ENDEREÇAMENTO

Estrutura de Sentimento, Gênero Televisivo e Modo de Endereçamento são tomados aqui como conceitos metodológicos, ou seja, eles devem encontrar sua melhor perspectiva através de estudos em que sejam usados como instrumentos para trabalhar materiais empíricos - colocando-lhes questões e organizando sua observação (BRAGA, 1997). Os três conceitos têm em comum sua origem - nasceram do esforço da análise cultural e sua preocupação com o sujeito, com o processo ativo de produção de sentido na cultura. Nesse sentido, em diferentes estágios ou níveis, eles colocam atenção sobre os receptores e os processos de recepção.

Estrutura de sentimento é um conceito que habilita o analista a estar atento aos significados e deslocamentos de significados que as palavras-chave que definem o jornalismo como instituição - objetividade, im- 
parcialidade, verdade, relevância, pertinência, factualidade, interesse público, responsabilidade social, liberdade de expressão, atualidade, quarto poder, para dizer apenas algumas - adquirem. Nesse sentido, ele permite um olhar para o processo, para o modo como o telejornalismo é construído processualmente e, assim, acessar a emergência de novas características que ainda não se cristalizaram em ideologias, convenções, normas, gêneros. A adoção do conceito de gênero televisivo deve possibilitar ao analista o reconhecimento da existência de relações sociais e históricas entre determinadas formas culturais - no nosso caso, os programas jornalísticos televisivos - e as sociedades e períodos nos quais essas formas são praticadas. Ele permite compreender as regularidades e as especificidades em produtos que se configuram historicamente - ele permite dizer tanto do jornalismo como ideologia, valores, normas, quanto das formas culturais historicamente dadas - e, sobretudo, vincular nosso objeto de análise ao processo comunicacional - gênero televisivo é uma estratégia de comunicabilidade. Modo de endereçamento, na medida em que diz do modo como um determinado programa se relaciona com sua audiência a partir da construção de um estilo, deverá permitir ao analista compreender como essas questões são atualizadas em um produto específico, objeto da análise. Em seguida, apresentamos cada um dos conceitos, buscando evidenciar seu potencial metodológico.

\section{ESTRUTURA DE SENTIMENTO}

Metodologicamente, estrutura de sentimento é apresentada por Raymond Williams como uma hipótese cultural que nos permitiria estudar a relação entre os diferentes elementos de um modo de vida ${ }^{11}$. O conceito aparece pela primeira vez em The long revolution, no capítulo dedicado à análise da cultura, e continuará a ser trabalhado por Williams até Marxismo e literatura, no qual aparece como um capítulo autônomo dentro da parte dedicada à teoria cultural. Depois disso, o conceito será

11 O conceito de cultura como modo de vida é desenvolvido por Willliams em Culture and society. Para o autor, a ideia de cultura como um modo inteiro de vida vem mostrar que a mudança social nunca é parcial: a alteração em qualquer elemento de um sistema complexo afeta seriamente o conjunto. 
abandonado pelo autor, apesar de seu potencial teórico-metodológico. Do ponto de vista do que nos interessa aqui, acreditamos que estrutura de sentimento poderá ser útil à compreensão e à abordagem do jornalismo como instituição social: permite olhar para o que é socialmente instituído como normas, valores, convenções do campo e o que é vivido, o que é a prática cotidiana e o que ela contém de características e qualidades que ainda não se cristalizaram em ideologias e convenções.

Estrutura de sentimento é um termo difícil. Com ele Williams (1961, p. 48) quer se referir a algo "[...] tão firme e definido como sugere a palavra 'estrutura', ainda que opere nos espaços mais delicados e menos tangíveis de nossa atividade". "Sentimento" aparece aí para marcar uma distinção em relação aos conceitos mais formais de visão de mundo ou ideologia, para dar conta de significados e valores tais como são vividos e sentidos ativamente, levando em consideração que "[...] as relações entre eles e as crenças formais ou sistemáticas são, na prática, variáveis (inclusive historicamente variáveis), em relação a vários aspectos" (WILLIAMS, 1971, p. 134), enquanto "estrutura" quer chamar a atenção para elementos que se apresentam "[...] como uma série, com relações internas específicas, ao mesmo tempo engrenadas e em tensão”. De todo modo, estrutura de sentimento se refere a uma experiência social que está em processo ou em solução, com frequência ainda não reconhecida como social. Com ele, Williams pensa poder acessar a emergência de novas características que ainda não se cristalizaram em ideologias, convenções, normas, gêneros.

Admitimos que o conceito é difícil, que apresenta problemas na sua formulação e na sua operacionalização, mas acreditamos que ele é um conceito-chave no pensamento de Williams e tem forte potencial metodológico e teórico.

Beatriz Sarlo (1997) propõe articular estrutura de sentimento com as noções de dominante, residual e emergente que Williams utiliza em Marxismo e literatura para descrever elementos de diferentes temporalidades e origens que configuram o processo cultural. Segundo Williams (1997), é claro que a análise cultural deve considerar as características dominantes de um determinado processo ou sistema cultural, mas o analista 
precisa estar atento também a um certo senso de movimento, de processo histórico, e às articulações e inter-relações complexas entre esses elementos dominantes e os residuais, aqueles elementos que foram efetivamente formados no passado, mas ainda estão ativos no processo cultural, não só como elemento do passado, mas como um elemento efetivo do presente, e emergentes, novos significados e valores, novas práticas, novas relações e tipos de relação que são efetivamente criados e que aparecem como substancialmente alternativos ou opostos na cultura dominante. Segundo o autor, é "com as formações emergentes que a estrutura de sentimento, como solução, se relaciona” (WILLIAMS, 1971, p. 136):

[...] o que temos de observar é, com efeito, uma emergência preliminar, atuante e pressionante, mas ainda não perfeitamente articulado... É para compreender melhor essa condição de emergência preliminar, bem como as formas mais evidentes do emergente, do residual e do dominante, que devemos explorar o conceito de estruturas de sentimento. (WILLIAMS, 1971, p. 129, grifo do autor)

Trabalhar com a hipótese cultural da estrutura de sentimento impede olhar o telejornalismo apenas como cristalização, impede também observá-lo como unidimensional, mas, ao contrário, favorece recuperar as fissuras, as ranhuras das práticas jornalísticas culturalmente vividas. Nesse sentido, se acolhemos estrutura de sentimento como um conceito metodológico, o jornalismo não poderá nunca ser considerado, para fins da análise, como uma "escola", como uma instituição claramente e indefinidamente estadunidense ou anglo-saxônica que se espalha pelo mundo global - existirão tantos jornalismos quantas são as culturas, as sociedades e os tempos históricos em que ele é praticado e o trabalho do analista é encontrar as marcas da sua heterogeneidade constitutiva, a copresença, em seus produtos, de elementos dominantes, residuais e emergentes.

Ao longo de todo o seu trabalho de configuração de uma teoria da cultura e de uma história cultural da arte e da comunicação, Williams vai buscar compreender as articulações entre os elementos dominantes, residuais e emergentes através da história das palavras e ideias. 
Williams pensava que, nos deslocamentos e na acumulação de sentidos operados nas palavras-chave, podiam ser lidos, como se a língua fosse o suporte histórico de um mapa cultural, os avatares da mudança nas instituições políticas e sociais bem como os das relações entre elas e as práticas culturais. (SARLO, 1997, p. 93)

Para os fins que nos interessam aqui, de configuração de uma metodologia de análise de programas jornalísticos televisivos, não se trata de ocupar o analista com a historiografia das palavras que constituem o jornalismo. Trata-se, antes, de estar atento ao trabalho dos historiadores do jornalismo e de, na análise de produtos concretos, observar os significados e deslocamentos de significados que as palavras-chave que definem o jornalismo como instituição - objetividade, imparcialidade, interesse público, responsabilidade social, liberdade de expressão, atualidade, quarto poder, para dizer apenas algumas - adquirem.

\section{GÊNERO TELEVISIVO}

Há algum tempo vimos tentando fazer dialogar os estudos culturais e os estudos da linguagem assumindo como ponto de convergência a discussão sobre os gêneros - discursivos, textuais, literários - e a possibilidade de articulação de uma teoria dos gêneros televisivos. (GOMES, 2002) Falando a propósito dos gêneros literários, Raymond Williams afirma que uma discussão sobre o gênero supõe o reconhecimento de dois fatos:

Primeiro, a existência de relações sociais e históricas claras entre determinadas formas literárias e as sociedades e os períodos nos quais foram originadas ou praticadas; segundo, a existência de continuidades indubitáveis nas formas literárias através e além de sociedades e períodos com os quais têm essas relações. Na teoria dos gêneros, tudo depende do caráter e processo dessas continuidades. (WILLIAMS, 1979, p. 182)

Reconhecemos, com Williams, a existência de relações sociais e históricas entre determinadas formas culturais e as sociedades e períodos nos quais essas formas são praticadas. Reconhecemos, igualmente, que um 
gênero é um modo de situar a audiência televisiva, em relação a um programa, em relação ao assunto nele tratado e em relação ao modo como o programa se destina ao seu público. No entanto, acreditamos que podemos avançar numa teoria dos gêneros e na avaliação de programas jornalísticos televisivos se adotarmos a concepção de gênero televisivo ou gênero midiático, concepção sustentada pela ênfase no processo comunicacional instaurado por uma determinada forma cultural:

[...] a análise dos processos midiáticos em sua categorização por gênero repousa sobre a idéia de que tanto os produtos quanto os processos de recepção desses produtos são elementos interdependentes do processo de produção de sentido dos discursos sociais ligados ao fenômeno midiático. (JANOTTI JR, 2005, p. 3)

Nesse sentido, colocar a atenção nos gêneros televisivos implica reconhecer que o receptor orienta sua interação com o programa e com o meio de comunicação de acordo com as expectativas geradas pelo próprio reconhecimento do gênero.

O gênero não é algo que passa ao texto, mas algo que passa pelo texto... O gênero é uma estratégia de comunicação, ligada profundamente aos vários universos culturais...O gênero não é só uma estratégia de produção, de escritura, é tanto ou mais uma estratégia de leitura. (BARBERO, 1995, p. 64)

Os gêneros são formas reconhecidas socialmente a partir das quais se classifica um produto midiático. Em geral, os programas individualmente pertencem a um gênero particular, como a ficção seriada ou o programa jornalístico, na TV, e é a partir desse gênero que ele é socialmente reconhecido. No caso da recepção televisiva, por exemplo, os gêneros permitem relacionar as formas televisivas com a elaboração cultural e discursiva do sentido.

Os programas telejornalísticos são, então, considerados como uma variação específica dentro da programação televisiva, enquanto compondo, no seu conjunto, um gênero - programa jornalístico televisivo, que obedece a formatos e regras próprias do campo jornalístico em negociação com o campo televisivo. Os telejornais, programas de entrevistas, 
documentários televisivos, as várias formas de jornalismo temático (esportivos, rurais, musicais, econômicos) são variações dentro do gênero: podemos chamá-los subgêneros ou formatos. E demandam ser abordados em categorias que impliquem considerá-los, ao mesmo tempo, como um produto de jornalismo televisivo - o que implica uma abordagem que leve em conta a linguagem televisiva e os elementos próprios do campo jornalístico - e como um produto comunicacional - o que implica uma abordagem da interação como os telespectadores.

O gênero televisivo, no entanto, é algo da ordem da virtualidade (DUARTE 2004, p. 67), ou seja, não podemos encontrar por aí um exemplar puro de um gênero. Como virtualidade, entretanto, o gênero encontra sua atualização em programas específicos e, no sentido que adotamos aqui, no modo de endereçamento que cada programa constrói na relação com os receptores.

\section{MODO DE ENDEREÇAMENTO}

O conceito de modo de endereçamento surge na análise fílmica, especialmente aquela vinculada à screen theory e tem sido, desde os anos 80 , adaptado para interpretação do modo como os programas televisivos constroem sua relação com os telespectadores. Modo de endereçamento é aquilo que é característico das formas e práticas comunicativas específicas de um programa, diz respeito ao modo como um programa específico tenta estabelecer uma forma particular de relação com sua audiência. (MORLEY; BRUNSDON, 1978) A análise do modo de endereçamento associada ao conceito de gênero televisivo deve nos possibilitar entender quais são os formatos e as práticas de recepção solicitadas e historicamente construídas pelos programas jornalísticos televisivos. Na nossa perspectiva, o conceito de modo de endereçamento tem sido apropriado para ajudar a pensar como um determinado programa se relaciona com sua audiência a partir da construção de um estilo, que o identifica e que o diferencia dos demais.

Pensando sobre os modos de endereçamento no cinema, Elizabeth Ellsworth (2001, p. 11) resume o conceito na seguinte questão: "quem esse filme pensa que você é?”. O modo de endereçamento é um conceito 
que se refere a algo que está no texto - ou no programa, diríamos nós - e que age, de alguma forma, sobre seus espectadores imaginados ou reais. Há uma certa distinção, entretanto, no modo como o conceito é compreendido pela teoria do cinema e pelos estudiosos da recepção televisiva. Num caso, ele é entendido como o estilo do programa. Noutro, ele se refere a subject positions construídas pelo filme: os semiólogos ligados à Screen sugeriam que a audiência era posicionada pelos textos fílmicos através do uso da câmara, em particular pelos enquadramentos fílmicos, pelas tomadas. Mais recentemente, os autores têm optado por falar de modos de endereçamento - no plural -, na perspectiva de que podem ser várias as posições de sujeito que os espectadores são convocados a ocupar num filme específico.

"O modo de endereçamento não é um momento visual ou falado, mas uma estruturação - que se desenvolve ao longo do tempo - das relações entre o filme e os seus espectadores" (ELLSWORTH, 2001, p.17), é um processo invisível que parece convocar o espectador a uma posição a partir da qual ele deva ler o filme. Alguns investigadores têm pensado esse convocar a partir do conceito de interpelação, tal como desenvolvido por Louis Althusser (1985, p. 93) a partir do psicanalista Jacques Lacan. Nesse caso, o modo de endereçamento deve ser pensado como um posicionamento dos espectadores. Nessa perspectiva, subject position implica uma necessária sujeição ao texto e, como já visto, a ideologia opera através da sujeição.

$\mathrm{Na}$ perspectiva da análise televisiva, o conceito tem sido apropriado para ajudar a pensar como um determinado programa se relaciona com sua audiência a partir da construção de um estilo, que o identifica e que o diferencia dos demais. O conceito vem sendo utilizado em estudos de recepção que se dedicam a uma análise comparativa dos discursos dos produtos televisivos e dos discursos de seus receptores, a exemplo de David Morley e Charlotte Brunsdon (1978, 1999), John Hartley (1997, 2000, 2001) e Daniel Chandler ([20--?]). Esses autores articulam os modos de endereçamento para compreender a relação de interdependência entre emissores e receptores na construção do sentido do texto televisivo. 
Segundo Morley e Brunsdon (1999, p. 262), o modo de endereçamento se caracteriza pela relação que o programa propõe para ou em conjunto com a sua audiência: "O conceito de 'modo de endereçamento' designa as específicas formas e práticas comunicativas que constituem o programa, o que teria referência dentro da crítica literária como o seu ‘tom’ ou o seu "estilo"”.

Daniel Chandler ([20--?]), por sua vez, chama a atenção para o fato de que a relação do nosso olhar com as imagens - pintura, fotografia, cinema, televisão - é social e historicamente construída. O modo de ver é uma construção. Recuperando a história da pintura, o autor nos lembra que a perspectiva linear, no Renascimento, constituiu um novo modo de olhar e, logo, um modo mais socialmente aceito de representar a verdade. A perspectiva é um código pictórico que apenas nos aparece como "natural" em razão de estarmos social e historicamente acostumados a "ler" as imagens de acordo com ele. E esse código nos posiciona fisicamente de um determinado modo em relação às imagens:

[...] o código renascentista de uma perspectiva centralizada em um ponto de vista linear não é simplesmente uma técnica para indicar profundidade e relativa distância num meio bi-dimensional. É um código pictórico que reflete o crescente humanismo daquele período, apresentando imagens de um ponto de vista visual singular, subjetivo, individual e único. CHANDLER ([20--?])

E mais, a perspectiva nos preparou para a câmera fotográfica: como disse McLuhan (1970), a fotografia é a mecanização da pintura em perspectiva.

Sem recusar a perspectiva da subject position, Daniel Chandler destaca a relação que o texto constrói com o espectador e associa ao modo de endereçamento aspectos sociais, ideológicos e textuais. São fatores relacionados ao modo de endereçamento o contexto textual, que inclui as convenções de gênero e a estrutura sintagmática, o contexto social, que diz da presença/ausência do produtor do texto, da composição da audiência, de fatores institucionais e econômicos, e os constrangimentos tecnológicos, que se referem às características de cada meio. 
Assim, entendemos que o modo de endereçamento depende de, se estrutura a partir das características de cada meio, tanto no que se refere ao suporte quanto às formas culturais (WILLIAMS, 1997) adquiridas por cada meio em sociedades particulares. Nessa perspectiva, por exemplo, a televisão difere do cinema em termos de suas possibilidades técnicas, de seus recursos de linguagem, dos gêneros adotados, da relação estabelecida com o público numa perspectiva histórica, das convenções que regulam as expectativas da audiência para cada um dos meios.

Na nossa abordagem, o conceito de modo de endereçamento, quando aplicado aos estudos de jornalismo, nos leva a tomar como pressuposto que quem quer que produza uma notícia deverá ter em conta não apenas uma orientação em relação ao acontecimento, mas também uma orientação em relação ao receptor. Esta “orientação para o receptor” é o modo de endereçamento e é ele que provê grande parte do apelo de um programa para os telespectadores. (HARTLEY, 2001, p. 88) O modo de endereçamento, em Hartley, se refere ao tom de um telejornal, àquilo que o distingue dos demais e nessa perspectiva, portanto, o conceito nos leva não apenas à imagem da audiência, mas ao estilo, às especificidades de um determinado programa.

Aqui, portanto, adotamos o conceito de modo de endereçamento naquilo que ele nos diz, duplamente, da orientação de um programa para o seu receptor e de um modo de dizer específico; da relação de interdependência entre emissores e receptores na construção do sentido de um produto televisivo e do seu estilo. Nessa perspectiva, o conceito de modo de endereçamento se refere ao modo como um determinado programa se relaciona com sua audiência a partir da construção de um estilo, que o identifica e que o diferencia dos demais. Ele permite verificar como instituição social e forma cultural se atualizam num programa específico.

No esforço de construir uma metodologia de análise do telejornalismo, buscamos a articulação entre estrutura de sentimento, gênero televisivo e modo de endereçamento. A associação entre esses conceitos pode se mostrar uma boa base conceitual e metodológica para análise e crítica do telejornalismo porque nos permite considerar o telejornalismo, a um só tempo, uma instituição social e uma forma cultural e, portanto, proceder 
a uma análise que faculte a consideração de um produto midiático a partir da sua vinculação com a história e com o contexto, sem abrir mão da análise concreta dos programas. É nesse sentido que dizemos que esses são conceitos metodológicos: seu potencial deve ser avaliado na medida mesmo em que eles se prestem à análise dos produtos midiáticos concretos.

\section{OS OPERADORES DE ANÁLISE DOS MODOS DE ENDEREÇAMENTO}

A análise de programas jornalísticos televisivos, como parece óbvio, deve considerar os elementos que configuram os dispositivos propriamente semióticos da TV, os elementos da linguagem televisiva - os recursos de filmagem, edição e montagem de imagem e de som empregados pelos programas jornalísticos - e os elementos propriamente verbais. A análise deve nos levar ao que é específico da linguagem televisiva, tal como construída num determinado programa e, consequentemente, tal como socialmente partilhado pela audiência. A gravação ao vivo, as simulações, bem como infográficos, mapas do tempo, vinhetas, telões e cenários virtuais formam o conjunto dos recursos que, para além de credibilidade, dão agilidade e ajudam a construir a identidade dos programas e das emissoras. A análise do texto verbal, por sua vez, deve revelar as estratégias empregadas pelos mediadores para construir as notícias, interpelar diretamente a audiência e construir credibilidade.

Nossos esforços de análise, no entanto, têm nos mostrado que a descrição dos elementos semióticos não é suficiente para compreender as estratégias de configuração do modo de endereçamento e nos colocam diante da necessidade de construção de operadores de análise que favoreçam a articulação dos elementos semióticos aos elementos discursivos, sociais, ideológicos, culturais e propriamente comunicacionais. É nesse sentido que desenvolvemos os operadores de análise do modo de endereçamento, que apresentamos em seguida. Ressaltamos, no entanto, que não se trata de categorias de análise, na medida mesmo em que não são excludentes e não são exaustivos, e nem se organizam a partir de quaisquer regras externas ao programa telejornalístico objeto de análise. É o modo mesmo de configuração dos programas que dirá ao analista a 
partir de quais operadores um programa concreto se constrói. Os operadores se articulam entre si, não devem ser observados nem interpretados isoladamente. Ao mesmo tempo, é importante tomar em conta que o objetivo de análise não deve ser descrever ou interpretar cada um dos operadores isoladamente, mas, através dos operadores, acessar o modo de endereçamento de um programa específico: os operadores são os "lugares" para onde o analista deve olhar, não o fim último do esforço analítico. A seguir, apresentamos os operadores de análise que estamos desenvolvendo.

1. O mediador. Programas jornalísticos televisivos contam com apresentadores ou âncoras, comentaristas, correspondentes e repórteres. Sem dúvida, em qualquer formato de programa jornalístico na televisão, o apresentador é a figura central, aquele que representa a "cara" do programa e que constrói a ligação entre o telespectador, os outros jornalistas que fazem o programa e as fontes. Assim, para compreender o modo de endereçamento, é fundamental analisar quem são os apresentadores, como se posicionam diante das câmeras e, portanto, como se posicionam para o telespectador. Mas o modo de endereçamento diz respeito também aos vínculos que cada um dos mediadores (âncoras, comentaristas, correspondentes, repórteres) estabelece com o telespectador no interior do programa e ao longo da sua história dentro do campo, à familiaridade que constrói através da veiculação diária/semanal do programa, à credibilidade que constrói no interior do campo midiático e que "carrega" para o programa, ao modo como os programas constroem a credibilidade dos seus profissionais e legitimam os papéis por eles desempenhados. A noção de performance, tal como utilizada no teatro, pode se mostrar um importante recurso descritivo para este operador analítico. A noção põe em relevo o caráter interpretativo do desempenho dos atores, dos mediadores televisivos: o ator representa a partir de seu próprio corpo, de suas próprias características, mas ele desempenha um papel. A performance do mediador é um aspecto central dos modos de endereçamento dos programas telejornalísticos - isso se torna mais evidente em programas como Cidade Alerta e Balanço Geral, por exemplo, que se organizam muito claramente a partir da competência performática de seus apresentadores, e em programas de entrevista, mas também 
está presente nos mais discretos telejornais. O mediador é o responsável pela predominância do verbal na televisão e, nesse sentido, adotaremos como ferramenta para observação do texto verbal dos mediadores as estratégias narrativas e argumentativas desenvolvidas, considerando os recursos retóricos e persuasivos empregados.

2. O contexto comunicativo. Este operador de análise se refere ao "contexto comunicativo" em que o programa televisivo atua, contexto que compreende tanto emissor, quanto receptor e mais as circunstâncias espaciais e temporais em que o processo comunicativo se dá. A comunicação tem lugar em um ambiente físico, social e mental partilhado. Isso pode ser melhor explicado pelo recurso à noção de instruções de uso de um texto, ou seja, aqueles princípios reguladores da comunicação os modos como os emissores se apresentam, como representam seus receptores e como situam uns e outros em uma situação comunicativa concreta. Um programa jornalístico sempre apresenta definições dos seus participantes, dos objetivos e dos modos de comunicar, explicitamente ("você, amigo da Rede Globo", "para o amigo que está chegando em casa agora”, "esta é a principal notícia do dia”, "Agilidade, dinamismo e credibilidade é o que queremos trazer para você", "você é meu parceiro, nós vamos juntos onde a notícia está”) - ou implicitamente - através das escolhas técnicas, do cenário, da postura do apresentador.

3. O pacto sobre o papel do jornalismo. A relação entre programa e telespectador é regulada, com uma série de acordos tácitos, por um pacto sobre o papel do jornalismo na sociedade. É esse pacto que dirá ao telespectador o que deve esperar ver no programa. Para compreensão do pacto é fundamental a análise de como o programa atualiza as premissas, valores, normas e convenções que constituem o jornalismo como instituição social de certo tipo, em outras palavras, como lida com as noções de objetividade, imparcialidade, factualidade, interesse público, responsabilidade social, liberdade de expressão e de opinião, atualidade, quarto poder, como lida com as ideias de verdade, pertinência e relevância da notícia, com quais valores-notícia de referência opera. Os recursos técnicos a serviço do jornalismo, ou seja, o modo como as emissoras lidam com as tecnologias de imagem e som colocadas a serviço do jornalismo, o modo como exibem para o telespectador o trabalho 
necessário para fazer a notícia são fortes componentes da credibilidade do programa e também da emissora e importantes dispositivos de atribuição de autenticidade. A exibição das redações como pano de fundo para a bancada dos apresentadores na maior parte dos telejornais atuais é apenas uma dessas estratégias de construção de credibilidade e, ao mesmo tempo, de aproximação do telespectador, que se torna, assim, cúmplice do trabalho de produção jornalística. Mas as transmissões ao vivo ainda são o melhor exemplo do modo como os programas buscam o reconhecimento da autenticidade de sua cobertura por parte da audiência - redes internacionais como a CNN e a BBC são exemplares nesse sentido. Os formatos de apresentação da notícia: nota, reportagem, entrevista, indicador, editorial, comentário, resenha, crônica, caricatura; enquete, perfil, dossiê e cronologia e a relação com as fontes de informação são outros aspectos que devem ser observados, pois dizem das escolhas jornalísticas realizadas. Os conceitos de lugar de fala (BRAGA, 1997) e de frame, aqui entendido como quadros narrativos construídos pelo programa para "emoldurar" suas construções noticiosas, têm se mostrado dispositivos analíticos úteis na identificação do pacto sobre o papel do jornalismo.

4. Organização temática. A arquitetura dessa organização implica, por parte do programa, a aposta em certos interesses e competências do telespectador. No caso dos programas de jornalismo temático, parece quase óbvio dizer que a temática é o operador de maior importância para a análise do modo de endereçamento - programas esportivos, programas culturais, programas ecológicos. Nesses casos, cabe analisar como a temática é abordada e como se articula aos outros operadores de análise. Para os telejornais, entretanto, a análise da organização temática demanda maior atenção e por vezes só pode ser compreendida através da observação do modo específico de organizar e apresentar as diversas editorias e do modo específico de construir a proximidade geográfica com sua audiência.

Do ponto de vista da análise, o pressuposto teórico-metodológico de que o telejornalismo é uma instituição social e uma forma cultural deve ser avaliado em sua encarnação concreta num programa específico. Os conceitos de estrutura de sentimento, de gênero televisivo e de modo de 
endereçamento devem guiar o exame concreto do telejornalismo, considerado, no primeiro caso, com o conceito de estrutura de sentimento, a partir da relação entre elementos dominantes, residuais e emergentes; no segundo, de gênero televisivo, a partir da existência de relações sociais e históricas entre as formas que o telejornalismo assume ao longo do tempo e as sociedades em que essas formas são praticadas; no terceiro, do modo de endereçamento, a partir do modo como um programa específico se relaciona com seus telespectadores a partir da construção de um estilo e, ao fazer isso, configura e reconfigura o próprio gênero.

Ressaltamos, entretanto, que o gênero televisivo é algo da ordem da virtualidade, mas, como virtualidade, ele encontra sua atualização em programas específicos e, no sentido que adotamos aqui, nos modos de endereçamento que cada programa constrói na relação com os receptores. O modo de endereçamento, por sua vez, enquanto atualização do gênero televisivo, contribui para construí-lo. A tarefa do analista, nesse sentido, não é buscar na programação televisiva os exemplos de gênero, nem construir classificações e tipificações, de resto pouco úteis diante da diversificação de formatos dos programas jornalísticos televisivos, com forte hibridização, mas é a de compreender como especificidades e regularidades configuradas pelo gênero televisivo se realizam em cada programa concreto.

Considerar o telejornalismo como instituição social e como forma cultural e tomar estrutura de sentimento, gênero televisivo e modo de endereçamento como conceitos metodológicos demanda que a análise do produto telejornalístico seja fortemente contextualizada: contextualização do programa na grade de programação da emissora, contextualização do programa em relação à emissora, entendida enquanto marca e enquanto organização jornalística, contextualização em relação à concorrência, contextualização em relação à televisão e em relação ao jornalismo, contextualização em relação à sociedade e à cultura. Essa contextualização não deve ser um pretexto para abandonarmos o programa televisivo em prol de uma análise que, embora tome o programa como ponto de partida, rapidamente se volte para outros objetos. A contextualização deve ter como objetivo compreender o programa 
como produto cultural específico, enquanto conjunto de estratégias histórica, econômica, cultural, ideológica e socialmente marcadas. A contextualização, para os fins que nos interessam aqui, não se transforma no objeto de investigação, mas deve nos ajudar a melhor compreender o objeto - o programa. Analisar o contexto em que um programa se insere deve significar, no esforço mesmo de análise, verificar como um programa específico apela, faz referência a, convoca seu contexto. Em outros termos, quando analisamos um programa - por exemplo, o Linha Direta, da Rede Globo ${ }^{12}$ - devemos nos perguntar em que Brasil esse programa é possível, em que jornalismo e em que sociedade podemos tão facilmente passar da factualidade à dramaturgia, em que emissora um programa jornalístico pode incorporar tão naturalmente o uso de atores, os enquadramentos e planos da telenovela, como um programa televisivo se constrói na relação, ao mesmo tempo, com os gêneros televisivos e com o gênero policial, ou seja, como convoca uma certa competência cultural dos seus receptores em relação ao gênero policial - no cinema, na literatura.

Propomos que essa análise deva ser marcadamente histórica, ou seja, que ela se dê na consideração de uma história cultural da televisão - é preciso que a análise de um programa observe como ele se inscreve no contexto histórico, técnico, econômico, social, cultural de formação da televisão em uma determinada sociedade e do momento específico em que o programa em questão é transmitido - e de uma história cultural do jornalismo - nesse caso, é preciso tomar em consideração na análise como valores e normas que configuram o jornalismo e as expectativas sociais sobre o jornalismo tomam corpo em um programa telejornalístico específico, como esse programa atualiza essas normas e valores jornalísticos socialmente reconhecidos. É em relação a esse contexto também que se torna importante considerar como concepções de jornalismo se relacionam com concepções sobre a sociedade e a cultura (sobre sua economia, suas instituições, as relações de poder, suas formas de pensamento).

12 Disponível em: <http://linhadireta.globo.com/>. Ver: Duarte (2007). 


\section{REFERÊNCIAS}

ALBUQUERQUE, Afonso de. A identidade jornalística no Brasil: algumas questões teóricas e metodológicas. E-Compós: Revista da Associação Nacional dos Programas de Pós-Graduação em Comunicação, v. 1, p. 1-14, 2004. . Media criticism à brasileira: o observatório da imprensa. In: ENCONTRO ANUAL DA COMPÓS, 10., 2001, Brasília. [Anais...] Brasília: [s.n.], 2001. . Um outro quarto poder: Imprensa e compromisso político no Brasil. Revista Fronteiras - Estudos Midiáticos, v. 1, n. 1, dez. 1999.

ALTHUSSER, Louis. Aparethos Ideológicos de Estado: nota sobre os aparelhos ideológicos de Estado. 2. ed. Tradução de Walter José Evangelista e Maria Laura Viveiros de Castro. Rio de Janeiro: Edições Graal, 1985, (Biblioteca de Ciências Sociais, v. 25). MARTÍN -BARBERO, Jésus Martín. América Latina e os anos recentes: o estudo da recepção em comunicação social. In: SOUSA, Mauro Wilton de (Org.). Sujeito, o lado oculto do receptor. São Paulo: Brasiliense, 1995. p. 39-68.

BERKOWITZ, Dan; LIMOR, Yehiel; SINGER, Jane. A crosscultural look at serving the public interest. American and Israeli journalists consider ethical scenarios, Journalism, v. 5, n. 2, 159-181, 2004.

BLUMLER, Jay; GUREVITCH, Michael. The crisis of public communication. London: Routledge, 1995.

BRAGA, José Luiz. Lugar de fala' como conceito metodológico no estudo de produtos culturais e outras falas. In: FAUSTO NETO, Antonio; PINTO, Milton (Org.). Mídia e cultura. Rio de Janeiro: Diadorim/Compós, 1997. p. 105-120. 
CHANDLER, Daniel. Semiotics for beginners, [20-- ?]. Disponível em <www.aber.ac.uk/media/Documents/S4B/semiotc.html $>$. cesso em: 15 ago. 2003.

DAYAN, Daniel. Pour une critique des médias Questions de Communication, n. 8, p.195-222, 2005.

. Quand montrer c'est faire. In: DAYAN, Daniel (Org.). La terreur spectacle: terrorisme et télévision. Paris : De Boeck/INA, 2006. 165-184.

DEUZE, Mark. What is journalism? Professional identity and ideology of journalists reconsidered. Journalism, London, v. 6, n. 4, p. 442-464, 2005.

DUARTE, Dannilo de Oliveira. Jornalismo policial na televisão: gênero e modo de endereçamento dos programas Cidade Alerta, Brasil Urgente e Linha Direta. 2007. Dissertação (Mestrado em Comunicação e Cultura Contemporânea), Faculdade de Comunicação, Universidade Federal da Bahia. Salvador.

DUARTE, Elizabeth Bastos. Televisão: ensaios metodológicos, Porto Alegre: Sulina, 2004.

ELLSWORTH, Elizabeth. Modos de endereçamento: uma coisa de cinema; uma coisa de educação também. In: SILVA, Tomaz Tadeu da (Org.). Nunca fomos humanos - nos rastros do sujeito. Belo Horizonte: Autêntica, 2001. p. 7-76.

FRANCISCATO, Carlos Eduardo. A atualidade no jornalismo: bases para sua delimitação teórica. 2003. Tese (Doutorado em Comunicação e Cultura Contemporâneas) - Faculdade de Comunicação, Universidade Federal da Bahia, Salvador. GOMES, Itania Maria Mota. Questões de método na análise do telejornalismo: premissas, conceitos, operadores de análise. Revista E-compos, n. 8, abr. 2007. Disponível em: <http:// www.compos.org.br/seer/index.php/e-compos/article/ view/126/126>. Acesso em: 20 set. 2010. 
GOMES, Itania Maria Mota. A noção de gênero televisivo como estratégia de interação: o diálogo entre os cultural studies e os estudos da linguagem. In: Revista Fronteira, São Leopoldo, v. 4, n. 2, p. 11-28, 2002.

Telejornalismo de qualidade: pressupostos teóricometodológicos para análise. Revista E-compos, n. 6, ago. 2006a.

. Das utilidades do conceito de modo de endereçamento para análise do telejornalismo. In: DUARTE, Elizabeth Bastos; \& CASTRO, Maria Lília Dias (Org.). Televisão: entre o mercado e a academia. Porto Alegre: Sulina, 2006b.

GOMES, Itania Maria Mota et al. Modo de endereçamento no telejornalismo do horário nobre brasileiro: o jornal nacional, da Rede Globo de Televisão. In: CONGRESSO BRASILEIRO DE CIÊNCIAS DA COMUNICAÇÃO - INTERCOM, 28, 2005, Rio de Janeiro. Congresso... Rio de Janeiro: [s.n.], 2005. Trabalho apresentado ao NP 07 - Comunicação Audiovisual.

. Quem o Jornal do SBT pensa que somos? Modos de endereçamento no telejornalismo show. Revista FAMECOS: Mídia, Cultura e Tecnologia, Porto Alegre, n. 25, p. 85-98, dez. 2004. GOMES, Luana. Fantástico, o show da vida: gênero e modos de endereçamento em programas televisivos. 2006. Trabalho de Conclusão de Curso. (Graduação em Jornalismo) - Faculdade de Comunicação, Universidade Federal da Bahia, Salvador. GOMES, Wilson da S. Esfera pública política e media: com Habermas, contra Habermas. In: RUBIM, A.; BENTZ, I.; PINTO, M. J. (Org.). Produção e recepção dos sentidos mediáticos. Petrópolis: Vozes, 1998. p. 155-185. . Jornalismos, fatos e interesses: ensaios de teoria do jornalismo. Florianópolis: Insular, 2009. . Transformações da política na era da comunicação de massa. São Paulo: Paulus, 2004; 
HALL, Stuart. Representation: cultural representation and signifying practices. London: Sage, 1997.

HARTLEY, John. Los usos de la televisión. Tradução de Juan Trejó Álvarez. Barcelona: Paidós, 2000. . Understanding News. London: Routledge, 2001.

HARTLEY, John et al. Conceptos clave en comunicación y estudios culturales. Buenos aires: Amorortu Editores, 1997.

JANOTTI JR, Jeder Silveira. Dos gêneros textuais, dos discursos e das canções: uma proposta de análise da música popular massiva a partir da noção de gênero midiático. In: ENCONTRO ANUAL DA COMPÓS, 14., 2005, Niterói. [Anais...] Nitérói: [s.n.], 2005. Trabalho apresentado no GT de Cultura das Mídias. Disponível em: <http://www.compos.org.br/data/biblioteca_825.pdf > . Acesso em: 21 out. 2010.

JENSEN, Klaus-Bruhn. Making sense of the news: towards a theory and an empirical model of reception for the study of mass communication. Aarhus/Dennmark: Aarhus University Press, 1986.

MACHADO, Arlindo. A televisão levada a sério. São Paulo: Editora Senac, 2000.

MARTIH-BARBERO; VÉLEZ, Marta Lucía. Questões metodológicas relacionadas com a análise da televisão. Revista E-composn. 8, abr. 2007. Disponível em: <http://www.compos. org.br>.

MORLEY, David; BRUNSDON, Charlotte. Everyday television: "nationwide". London: British Film Institute, 1978. . The Nationwide Television Studies. London: Routledge, 1999.

SARLO, Beatriz. Raymond Williams, uma releitura. In:

Paisagens Imaginárias. São Paulo: Edusp, 1997. p. 85-95. 
SCHUDSON, Michael. Discovering the news: a social history of american newspapers. New York: Basic Books Inc. Publishers, 1978.

. A política da forma narrativa: a emergência das convenções noticiosas na imprensa e na televisão. In: TRAQUINA, Nelson (Org.). Jornalismo: questões, teorias e estórias. Lisboa: Vega, 1993, p. 278 -293.

SEMPRINI, Andrea. CNN et la mondialisation de l'imaginaire. Paris: CNRS Editions, 2000.

TRAQUINA, Nelson (Org.). Jornalismo: questões, teorias e estórias. Lisboa: Vega, 1993.

WEAVER, Paul H. As notícias de jornal e as notícias de televisão. In: TRAQUINA, Nelson (Org.). Jornalismo: questões, teorias e estórias. Lisboa: Vega, 1993. p. 294-305.

WILLIAMS, Raymond. Cultura e sociedade: 1780-1950. Trad. de Leônidas H. B. Hegenberg, Octanny Silveira da Mota e Anísio Teixeira. São Paulo: Ed. Nacional, 1969. . The long revolution. Harmondsworth: Penguin, 1961. . Marxismo e literatura. Trad. de Waltensir Dutra. Rio de Janeiro, Jorge Zahar, 1979. . Television: technology and cultural form. 2th. ed. London: Routledge, 1997. 



\title{
O RODA VIVA e as estratégias de construção de um debate público
}

\author{
Fernanda Mauricio da Silva ${ }^{1}$
}

No ar desde setembro de 1986, o programa de entrevistas Roda Viva se estabeleceu como um lugar privilegiado de debate sobre assuntos públicos na televisão brasileira. Estreado um ano após o movimento das Diretas Já no Brasil, alinhado com os ideais de democracia participativa, e transmitido por uma TV pública, a TV Cultura de São Paulo, o Roda Viva, desde suas origens, tem se empenhado em colocar no centro de seu cenário, constituído em forma de arena, as principais personalidades nacionais e internacionais das áreas da política, artes, economia, cultura, esportes, educação e ciência, a fim de construir-se como um locus de discussão social. A revista Veja de 25 de fevereiro de 1987 atribuiu o sucesso do programa ao equilíbrio entre sobriedade e informalidade nos debates, diferentemente do que ocorria nos concorrentes do período, a exemplo do Canal Livre (TV Bandeirantes) e do Programa Ferreira Netto (TV Gazeta de São Paulo), que oscilavam entre "o ambiente de bate-papo entre amigos" e os "debates freqüentemente tumultuados", respectivamente. (DEBATE..., 1987, p. 113)

Exibido desde a estreia todas as segundas-feiras ${ }^{2}$, o Roda Viva assume como ideal "realizar jornalismo público de qualidade ao oferecer aos telespectadores a possibilidade de conhecer o pensamento e o trabalho de personalidades nacionais e estrangeiras com profundidade" ${ }^{3}$. A promes-

1 Este texto é uma adaptação de um dos capítulos da tese intitulada A conversação como estratégia de construção de programas jornalísticos televisivos. Ver SILVA, 2010a.

2 O que variou ao longo do tempo foi o horário de exibição: inicialmente o programa ia ao ar às $21 \mathrm{~h} 20 \mathrm{~min}$. Durante o período analisado, o Roda Viva entrava em cena das $22 \mathrm{~h} 10 \mathrm{~min}$ às 23h40min. Ainda assim, a opção pela faixa horária do fim da noite se mantém estável ao longo do tempo.

3 Informações do site oficial do programa. Disponível em: < http://www.tvcultura.com.br/rodaviva>. Acesso em: 20 abr. 2009. 
sa de um jornalismo de qualidade busca se concretizar por meio da proposta de reflexão e aprofundamento dos assuntos que o programa discute em seus cinco blocos de exibição. Por conta disso, o Roda Viva pressiona o subgênero que o insere - programa de entrevistas - a partir de imbricações constantes com os programas de debates, já que é seu objetivo promover uma troca de ideias, opiniões e argumentos sobre os assuntos que concernem ao entrevistado e sua área de atuação. O tempo prolongado, a performance dos participantes, o estatuto dos interlocutores em cena, os enquadramentos temáticos e a abertura para a interatividade com o público são marcas do programa que parecem dar a tônica do modo de endereçamento do Roda Viva e justificarem seu sucesso e longevidade na história televisiva nacional ${ }^{4}$.

\section{TOMADA DE POSIÇÃO}

A história dos programas de entrevistas e debates no Brasil se inscreve no declínio da ditadura militar, no final da década de setenta e início dos anos oitenta. A morte do jornalista Wladmir Herzog 5 , em 1975, tornou-se um marco histórico para que a sociedade começasse a se manifestar contrariamente à censura, às perseguições e às torturas aos inimigos políticos, aos artistas de esquerda e à imprensa. Aproveitando o clima de tensão e protesto que se instalava no período, a programação televisiva se abriu para o formato da entrevista e do debate, antes limitado a poucos exemplares ${ }^{6}$. Com o governo militar enfraquecido, os programas televisivos se encarregaram de suscitar o debate público e dar visibilidade aos temas e personalidades antes pouco discutidos, ocupando, portanto, a função de porta-voz da sociedade. Nesse rastro, Abertura (TV Tupi), Vox

4 A presente análise leva em conta o período de 2006 a 2008, mas para efeito de exemplificação foram selecionadas randomicamente dez edições referentes a esse momento do Roda Viva. Em 2010, o programa, assim como a própria TV Cultura, passou por diversas reformulações, ainda que mantivesse sua proposta inicial: promover um debate público de qualidade. Para uma breve reflexão sobre as alterações no Roda Viva, ver SILVA, 2010b.

5 Herzog era diretor de A Hora da Notícia, telejornal da TV Cultura que denunciava os problemas da comunidade.

6 Mesa Redonda do Vídeo (1952), Globo Gente (1973) são alguns exemplos de programas no formato de entrevista e debate que fizeram a história da televisão antes da década de oitenta. 
Populi (TV Cultura), Encontro com a Imprensa (TV Bandeirantes), Diário Nacional (TV Record) e Canal Livre (TV Bandeirantes) atuaram como fomentadores da discussão sobre cultura, economia e política. Foi nesse contexto que o programa Roda Viva encontrou seu lugar na grade de programação brasileira e se justificava socialmente pela proposta de um debate de alto nível dos assuntos que concerniam à vida pública. Seguindo a tendência dos programas de sua época, o Roda Viva privilegiava a política, mas não se restringia a ela, abrindo espaço para representantes das artes, cultura, esportes, economia e do próprio campo televisivo.

Esses aspectos, construídos historicamente pelo programa, sofreram pequenas alterações ao longo do tempo, mas não perderam sua essência, de modo que ainda hoje a proposta de oferecer um jornalismo de qualidade por meio da reflexão sobre os assuntos públicos é o elemento central da construção do estilo do Roda Viva e o principal motivo para sua credibilidade entre a audiência e os críticos televisivos. O pacto sobre o papel do jornalismo se mostra ao telespectador na própria estrutura cênica do estúdio: uma arena, no centro da qual o entrevistado da rodada se posiciona e ao seu redor, numa arquibancada um nível acima, seus entrevistadores formam um círculo interrompido por três televisores. Através dessa estrutura, todos podem se entreolhar e o entrevistado pode se dirigir a qualquer lado. Essa constituição do cenário ${ }^{7}$, que o programa carrega desde a sua estreia, efetuando algumas variações, sugere que o centro do programa, ocupado pelo entrevistado, será o foco do debate. É para ele que todas as questões convergem e é ele que deverá responder à sabatina de perguntas formuladas pelo apresentador do programa, pelos demais mediadores convidados e pelos telespectadores que podem participar por e-mail ou por telefone.

Para asseverar o alto nível do programa, o Roda Viva investe, principalmente, no estatuto dos participantes, selecionados rigorosamente pela equipe de produção do programa, e na qualidade das perguntas

7 O cenário do Roda Viva foi concebido pelos jornalistas Marcos Weinstock, que se incumbiu da formatação, Roberto de Oliveira, coordenador da programação e Valdir Zwetsch, diretor de jornalismo da emissora. Quem assina a versão atual do cenário é João Baptista da Costa Aguiar e Célio Inada. 
feitas, elementos que, em seu conjunto, dão um caráter tenso e muitas vezes acirrado à conversa. As múltiplas vozes que o constituem possuem funções bem definidas que se complementam para costurar o estilo do programa. Em primeiro lugar e ocupando uma posição de destaque, o Roda Viva conta com um apresentador que faz a mediação entre a esfera da produção e o interesse público que representa e busca assegurar. Inúmeros jornalistas renomados já passaram por essa função, incluindo Rodolpho Gamberini, apresentador no período inicial do Roda Viva, Augusto Nunes, Matinas Suzuki, Heródoto Barbeiro, Jorge Escosteguy, jornalistas com um perfil vinculado aos cargos de chefia do jornalismo televisivo e impresso. De 1998 até o início de 2008, o jornalista Paulo Markun foi responsável pela mediação do Roda Viva, quando deixou a emissora para se tornar presidente da Fundação Padre José de Anchieta, mantenedora da TV Cultura. Após sua saída, o programa viveu um período de instabilidade contando com diversos apresentadores até chegar a Lílian Witte Fibe, jornalista que construiu sua carreira na TV como apresentadora do Jornal do Globo e do Jornal Nacional (ambos da TV Globo), com uma passagem pelo SBT e, posteriormente, pela apresentação do Jornal da Lílian no portal do Terra e, em seguida, no UOL News ${ }^{8}$.

A passagem da apresentação do Roda Viva de Markun para Lílian Witte Fibe, que se concretizou em abril de 2008, trouxe algumas modificações no próprio papel de apresentação. Paulo Markun evitava expressar algum tipo de emoção nas questões que levantava a seus entrevistados, aproximando-se de uma postura mais objetiva. Tal postura mantinha o apresentador no controle do programa que poderia chegar aos mais altos níveis de tensão, sem que ele se envolvesse de maneira intensa, nem com o conteúdo da conversação, nem com o entrevistado.

Lílian Witte Fibe, por sua vez, assume uma postura mais controladora da cena, determinando a passagem da palavra a fim de assegurar que todos os entrevistadores tenham espaço para suas intervenções. Por conta disso, é comum observar no discurso da apresentadora uma tentativa de

8 Atualmente, Marília Gabriela ocupa o cargo de apresentadora do Roda Viva, no entanto, esta análise irá se referir apenas ao período em que o programa foi comandado por Paulo Markun e Lílian Witte Fibe. 
organizar o debate: "o professor Armando ainda não abriu a boca" , "Nós precisamos fazer mais um intervalo e a gente volta já já com a entrevista do professor e economista Nicholas Stern"10. A apresentadora também não esconde uma afetação emocional quando coloca suas questões. A depender do assunto, Fibe pode se mostrar irritada, indignada, revoltada, variando o tom de voz para dar ênfase àquilo que pretende denunciar:

Lílian Witte Fibe - Ministro, eu confesso [...] A Declaração [dos Diretos Humanos] tem 60 anos, mas a lei da abolição da escravatura tem 120 anos. Eu morro de vergonha de saber, como brasileira, que a gente não conseguiu nem abolir a escravidão. Muito menos conseguir resgatar os diretos humanos. Se ainda tem escravidão no Brasil, e tem, né, o que a gente pode fazer, o que se pode fazer também a curtíssimo prazo, senão para ontem, para acabar com isso? [aumentando o tom de voz]11.

Embora cada apresentador traga sua marca pessoal, alguns atributos são típicos de quem ocupa a função de apresentação do Roda Viva. É o apresentador que se dirige diretamente ao telespectador por meio do eixo olho-a-olho (VERÓN, 1983) a fim de convocá-lo a acompanhar o debate que ali se passa. Além disso, cabe a ele fazer as interrupções para os comerciais (por meio de expressões como "a gente volta já", "nós vamos para um intervalo e voltamos num instante com o Roda Viva"), controlar o tempo do programa ("professor, nosso tempo acabou", "a gente tem trinta segundos para sua pergunta e a resposta dele"), convocar os telespectadores para enviarem perguntas via e-mail ou telefone ("para você participar, ligue para [...]"), vender os produtos do programa ("lembrando que a entrevista desta noite poderá ser encomendada em DVD a partir de amanhã [...]"), apresentar os demais mediadores e o convidado da rodada e, principalmente, direcionar os assuntos a serem debatidos. O apresentador representa uma autoridade institucional, tanto que é a ele que os entrevistados se reportam para pedir direcionamen-

9 Programa Roda Viva, edição de $1^{\circ}$ dez. 2008.

10 Programa Roda Viva, edição de 24 nov. 2008.

11 Programa Roda Viva, edição de 8 dez. 2008. 
tos como: "posso contar uma anedota?"12, "eu posso só complementar a pergunta do Oscar?" 13 .

As distinções entre Lílian e seu antecessor revelam diferenciações não apenas no modo de condução, mas principalmente na construção do tom do programa em relação ao subgênero. Paulo Markun parecia mais comprometido com a função de, por meio das entrevistas, promover um debate dos assuntos a partir da troca de opiniões. Assim, "debate", "discussão", "entrevista" e "conversa" apareciam como termos intercambiáveis no discurso do antigo apresentador do Roda Viva. Lílian Witte Fibe, por sua vez, não possuía tanta desenvoltura da condução do programa nos termos de um debate, procurando sempre encerrá-lo no subgênero das entrevistas, limitando a conversa ao sistema de perguntas e respostas. Tome-se como exemplo as entrevistas com Lula, conduzida por Paulo Markun ${ }^{14}$, e com o economista Nicholas Stern, por Lílian ${ }^{15}$. Paulo Markun, ao apresentar seu convidado esclarece: "em contrapartida aos debates programados, duas entrevistas destinadas a aprofundar a discussão de questões que devem pesar nesta definição eleitoral”, já Lílian refere-se à prática no programa sempre como entrevista: "o Roda Viva está entrevistando Nicholas Stern, consultor do governo inglês para assuntos climáticos". A rigidez da apresentadora para a distribuição dos turnos de fala e para a inclusão de todos os entrevistadores convidados na conversa não correspondeu à proposta de debate que o programa pretende trazer ao telespectador.

Compartilhando a função de mediação, mas a partir de outro lugar de fala, o Roda Viva convida para ocuparem o primeiro andar da arquibancada quatro jornalistas ${ }^{16}$ de veículos de comunicação reconhecidos pela qualidade da cobertura, especialidade dos assuntos ou mesmo pelos ín-

12 Mário Novello, Programa Roda Viva, edição de 4 de set. 2006.

13 Roberto Lameirinhas, edição de 21 ago. 2006.

14 Programa Roda Viva, edição de 16 out. 2006.

15 Programa Roda Viva, edição de 24 nov. 2008.

16 No seu surgimento, eram oito os entrevistadores que compareciam ao programa. Em 2006, esse número já havia caído para seis. Em 2008, o programa reduziu o número de entrevistadores convidados para quatro por edição. 
dices de audiência. É deles o papel de levantarem questões de interesse do telespectador e é por conta de sua performance que muitas vezes o programa adquire um caráter tenso e o debate chega ao acirramento desejado e compactuado com o telespectador. Podem fazer parte, também, do grupo de entrevistadores especialistas, representantes de instituições ou outras pessoas cujo cargo se relacione de algum modo com a área de atuação do entrevistado. Na entrevista com o escritor paquistanês Tariq $\mathrm{Ali}^{17}$, por exemplo, foram seus entrevistadores Demétrio Mag'noli, geógrafo, especialista em relações internacionais e editor do jornal Mundo, Geografia e Política Internacional, e Roberto Lameirinhas, repórter da editoria internacional do jornal O Estado de São Paulo ${ }^{18}$.

Ao abrir as portas do programa para profissionais de fora da TV Cultura, o Roda Viva sustenta a proposta de um jornalismo de qualidade, pois parece dizer à audiência que o debate ali será no nível dos mais importantes jornalistas e especialistas no assunto tratado, ainda que não façam parte do quadro da emissora. Retoricamente, o programa se reveste do discurso do jornalismo público, que desconhece fronteiras empresariais em nome do interesse público. Juntamente com o apresentador, são eles que perscrutam, investigam e tentam extrair do entrevistado a verdade que não é dita nos veículos convencionais do jornalismo diário informativo, efetivando sua função de vigilância e se posicionando como guardiões sociais da democracia.

Do lado oposto, encontra-se o entrevistado, o dono das ideias, opiniões, conhecimentos que devem se tornar públicos na arena do Roda Viva. O programa privilegia personalidades de destaque no cenário nacional ou internacional, seja pelo cargo que ocupam, seja pelas convicções, seja pelas polêmicas em que estão envolvidas, de modo que há nelas um diferencial e algo que as conecte com a atualidade: publicação de um livro, filme recém-lançado, inserção no momento social. Embora não possua

17 Edição de 21 ago. 2006.

18 Além deles, o programa contou com Vicente Adorno, comentarista de internacional da Rádio Cultura FM; Samuel Feldberg, professor de Relações Internacionais das Faculdades Rio Branco e membro do Gacint, Grupo de Análise e Conjuntura Internacional da Universidade de São Paulo; Emir Sader, sociólogo e escritor; Oscar Pilagallo, editor da revista Entrelivros. 
limites nas esferas de abrangência da especialidade do convidado - podendo ir dos esportes à ciência - há limites no status desse personagem para a vida pública, de modo que não é qualquer ator, cineasta ou político, que se senta no centro do Roda Viva, mas é Wagner Moura, aclamado pela crítica após o filme Tropa de Elite; Fernando Meirelles, indicado ao Oscar pelo filme Cidade de Deus e reconhecido pelo trabalho mais recente, a adaptação do romance Ensaio sobre a Cegueira, de José Saramago; e os candidatos à corrida presidencial no ano de 2006. Sua posição solitária no centro da arena o deixa exposto a todo tipo de questionamento que pode vir de qualquer lado, insinuando um lugar de fragilidade e desvantagem em relação aos entrevistadores que se impõem como autoridade, estando um nível acima do convidado. Se, por um lado, a disposição do cenário em dois níveis força o entrevistado a olhar sempre para cima para se dirigir a seus interlocutores, por outro, a situação de submissão é contrabalanceada pelo tempo mais alongado disponível para o desenvolvimento de suas ideias, mantendo-o no lugar central do programa.

É essa dinâmica que envolve entrevistados e entrevistadores que cria um sentido de "roda viva", sugerindo que tudo está mudando, se construindo, se reconfigurando. Desde a vinheta de abertura, o programa convoca o telespectador a "entrar na roda" e acompanhar, pelo Roda Viva, as transformações que acontecem ao seu redor por meio de um "debate vivo", como sugeriu uma reportagem de Veja (25 fev. 1987). Ao som da música de Chico Buarque que lhe empresta o nome ${ }^{19}$, imagens do mapa do mundo em tons de branco e cinza servem de fundo às letras que formam o nome do programa. Ao final de uma sequência de imagens, o quadro finalmente se completa e forma-se, sobre um fundo branco, o nome do programa em cinza e vermelho, sendo que o "O" que forma da palavra "RODA" é o globo terrestre que gira continuamente até se fundir com o globo que está

19 A canção Roda Viva (1967), de Chico Buarque, só passou a constituir a trilha sonora do programa da TV Cultura em 2008, 21 anos após sua estreia, quando o compositor cedeu os direitos da música à emissora. Anteriormente, a vinheta de abertura contava com a assinatura musical de John Naschling. Independentemente dos direitos de uso da música na abertura, o nome do programa convoca o imaginário do telespectador, atualizando a ideia de que "o mundo roda num instante", se transforma, se modifica e, por isso, o programa trata daquilo que é atual, o que é novo. 
no piso do cenário onde o entrevistado se posiciona. O programa sugere, por meio da vinheta, que, ali, os assuntos e as personalidades que "estão no centro do mundo" serão abordados de maneira viva, ativa e vigilante. No centro dessa roda, o convidado se vê acuado, sem ter outra alternativa, senão responder às questões dos entrevistadores.

Além desses enunciadores, o Roda Viva conta ainda com uma repórter da TV Cultura para servir como porta-voz das perguntas enviadas pelos telespectadores, uma plateia disposta no segundo nível da arquibancada, que participa do programa partilhando suas impressões por meio do twitter, ferramenta que permite a troca de mensagens instantâneas pela internet, e o cartunista Paulo Caruso, presente desde a estreia do programa, que faz suas interpretações do debate por meio de charges. A função de Caruso é perceber os momentos mais interessantes, as falas de maior repercussão, as ideias discutidas ressignificando-as para a audiência.

As charges de Caruso são captadas pela câmera durante todo o programa ainda em seu processo de produção, e revelam um olhar individual sobre os assuntos à baila no Roda Viva. São flagrados pelos desenhos de Caruso os entrevistadores, os convidados e personagens externos ao programa que possuem relação com o que está sendo debatido no momento. Segundo Santos (2005, p. 78), as charges de Caruso possuem três funções mais evidentes:

a) ilustram, com carga humorística, o diálogo que se dá diante das câmeras; b) fornecem um determinado enfoque para a análise da cena, sugerindo um viés para a análise das declarações dos convidados; e c) como conseqüência desta última característica, conferem a Paulo Caruso um privilegiado lugar de fala no Roda Viva, uma vez que seus desenhos emitem opinião sobre a entrevista sem contestação.

Os jornalistas empregam, majoritariamente, cinco tipos de pergunta para abordarem os assuntos no Roda Viva: 1) biográfica - "E você teve a infância na cidade de Rodelas. Eu soube que nessa cidade tem muito mármore [...] E você ficou lá os quinze anos, não é?" ${ }^{20}$; 2) confirmação de uma hipótese

20 Jefferson Del Rios a Wagner Moura, edição de 29 set. 2008. 
- [...] o senhor disse, já, que a questão do terrorismo emana muito mais da fraqueza do que propriamente da força. É uma colocação que eu acho que é aceita por muita gente, na verdade. Agora, eu não tenho certeza se é uma definição que possa ser aplicada de maneira geral ao terrorismo ou a um específico tipo de terrorismo que é aquele que vem exatamente de grupos que estão sendo esmagados por poderes maiores. Ou é uma definição que vale de uma maneira mais ampla. Como é que o senhor vê essa questão?21

\section{3) solução de problemas}

- [...] o senhor poderia relacionar algumas medidas simples, além da economia de água, do movimento pelo uso de produtos ecologicamente corretos dentro de casa, domésticos etc. que a população poderia adotar imediatamente para fazer a sua parte também?22

\section{4) informativa}

- [...] a cosmologia não tem uma fronteira com outros ramos do conhecimento, ou - não sei bem se a palavra se aplica -, de um lado, a filosofia e, do outro, a religião... não tem um meio-de-campo aí que é meio embolado?23

5) investigativas

- [...] a gente vive hoje em um Universo, segundo as versões dos próprios cosmólogos, em que 95\% de todo conteúdo do Universo, energia e matéria, a gente não tem a menor idéia do que seja. Por que, na opinião do senhor, alguém aqui deveria acreditar em uma versão cosmológica com base em $5 \%$ do que a gente conhece de todo o Universo? Por que $5 \%$ iriam contar a história inteira? ${ }^{24}$

Por meio desta última é que os jornalistas desempenham melhor o papel de fiscalização, de cães de guarda dos interesses do público e conso-

21 Oscar Pilagallo a Tariq Ali, edição de 21 ago. 2006.

22 Lílian Witte Fibe a Nicholas Stern, edição de 24 nov. 2008.

23 Paulo Markun a Mário Novello, edição de 4 set. 2006.

24 Salvador Nogueira a Mário Novello, edição de 4 set. 2006. 
lidam o pacto sobre o papel do jornalismo de efetivar um debate público a partir de critérios democráticos.

\section{DEBATE PÚBLICO NA DEMOCRACIA}

O Roda Viva se assume, retoricamente, como um espaço aberto a todo tipo de ideia e concepção de mundo ao pôr em diálogo personalidades em lados opostos na vida social. A excitação do momento eleitoral no ano de 2006 e os escândalos que envolviam o governo Lula foram bastante profícuos para a construção de uma arena supostamente neutra em termos de política partidária, uma vez que o programa levou para o centro de seu cenário os principais candidatos à corrida presidencial. Corroborando com essa postura, a edição de 02 out. 2006, que se configurou como uma mesa redonda ${ }^{25}$, promoveu um debate sobre o momento eleitoral com representantes dos principais partidos políticos do país, formando "duas bancadas: uma governista e outra de oposição", como destacou o apresentador Paulo Markun na abertura do programa ${ }^{26}$. Portanto, é na busca pelos múltiplos lados de uma mesma questão que o Roda Viva constrói sua proposta de debate, atualizando aquilo que configura, do modo mais tradicional, o subgênero: o confronto de ideias. Essa postura evoca um papel de vigilância exercido pelo programa, que permite à sociedade formular melhor suas opiniões por meio do tratamento diversificado das questões trazidas ao estúdio. Assim, o binômio pergunta/resposta funciona como alavanca para as trocas de argumentos entre entrevistadores e entrevistados.

Para além da busca pela informação, o Roda Viva propõe à audiência o tratamento de questões relevantes num nível argumentativo, partindo

25 Em certas edições, o Roda Viva muda seu formato de apresentação configurando-se como uma mesa de debates. Nesses casos, não há um entrevistado no centro da arena, mas convidados com diferentes pontos de vista trocam ideias sobre um tema comum.

26 Os convidados do programa nessa edição foram: Arlindo Chinaglia, deputado federal pelo PT de São Paulo, líder do governo na Câmara; Álvaro Dias, senador pelo PSDB no Paraná; Ideli Salvatti, senadora pelo PT de Santa Catarina e líder do partido no Senado; José Carlos Aleluia, deputado federal pelo então PFL da Bahia; Eunício Oliveira, deputado federal pelo PMDB do Ceará, parte da base de apoio do governo, e Osmar Serraglio, deputado federal pelo PMDB do Paraná. 
do pressuposto de que a audiência já possui as informações básicas para se integrar à conversa encenada. O programa, portanto, retoma um papel mais característico do jornalismo opinativo ${ }^{27}$ que consolidou os parâmetros que ainda hoje são tomados como definidores do campo: é opinativo porque permite a troca livre de opiniões que se consolidam em argumentos. Segundo Josenildo Guerra (2003, p. 36), a matriz opinativa do jornalismo está relacionada à política e compreende o jornalismo como "uma grande esfera de debate de ideias". "Nesta modalidade", continua o autor, "não são os fatos o eixo em torno do qual o discurso se estrutura, mas a tese pela qual o autor busca explicá-los". (GUERRA, 2003, p. 36) Guerra explica que foi nos momentos de maior instabilidade política que esse modelo de jornalismo se desenvolveu, atuando no processo de formação e persuasão dos indivíduos para abraçarem as causas liberais ${ }^{28}$. Para Guerra (2003), esse modelo de jornalismo se caracteriza pelo estilo polêmico e argumentativo dos textos, o engajamento político dos atores em um projeto de sociedade e o domínio dos princípios que norteiam as formas de governo e as alternativas desejadas. (GUERRA, 2003, p. 37) Assim, o Roda Viva se apropria de um modelo residual de jornalismo para construir sua legitimidade, efetuando hibridizações no subgênero que o concerne. O cenário político eleitoral do momento e as diversas carências sociais do país, tema da edição de 19 jun. 2006 sobre as dificuldades de acessibilidade dos portadores de deficiência física, tornam-se um ambiente profícuo para a existência desse programa e sua função social.

Se por um lado o programa semanal da TV Cultura se constrói para a audiência como um espaço aberto a qualquer visão de mundo, por ou-

27 Não se pretende efetuar uma análise com base em gêneros jornalísticos, como postulado por José Marques de Melo (1985), mas apenas retomar outra função do jornalismo que se constituiu anteriormente ao paradigma informativo, como aponta Josenildo Guerra (2003). O que está em jogo no Roda Viva não é a dimensão panfletária do jornalismo, mas sua constituição como espaço de troca de opiniões.

28 Segundo Marialva Barbosa (2007, p. 24), o jornalismo brasileiro viveu um período semelhante na passagem do sistema de governo monárquico para a República. A autora aponta o uso de novas tecnologias de comunicação - telégrafo, linotipo, cinematógrafo etc. - como catalisador da transformação do modelo opinativo para o informativo no jornalismo brasileiro: "a opinião é, assim, gradativamente separada de uma ideia de informação isenta e, neste processo, os novos artefatos tecnológicos desempenham papel fundamental”. 
tro, a postura dos entrevistadores não se mostra tão isenta de concepções preestabelecidas. A função que os mediadores assumem no programa é de contradição das ideias apresentadas pelos entrevistados e cobrança por esclarecimentos que ainda não foram prestados. Através de perguntas investigativas ${ }^{29}$ e de confirmação de hipóteses ${ }^{30}$, os jornalistas e, por conseguinte, o Roda Viva se colocam como cães de guarda do interesse público e vigilantes das ações políticas. A entrevista com Luiz Inácio Lula da Silva trouxe situações em que os jornalistas buscavam elucidar os escândalos que ainda envolviam sua administração:

Renata Lo Prete - Presidente, o senhor tem, ao falar dessa questão do dossiê [em setembro de 2006, 'vazou' um DVD com vídeos e fotos do candidato à presidência da República, Geraldo Alckmin, e do candidato ao governo de São Paulo, José Serra, ambos do PSDB, em cerimônias de entrega de ambulâncias vinculadas à Planam, ápice do escândalo dos Sanguessugas, com o objetivo de prejudicar as candidaturas dos opositores ao presidente], tem insistido muito em dizer que o senhor acabou sendo o maior prejudicado com isso, porque o senhor tinha a chance de fechar a eleição no primeiro turno e isso acabou não acontecendo. Agora, o senhor não acha que tem um problema nesse raciocínio, presidente, porque a gente também pode pensar o seguinte: o senhor só acabou sendo prejudicado porque essa operação deu errado, presidente. Porque se essas pessoas não tivessem sido presas, se os vendedores tivessem comparecido com um dossiê de verdade e se os compradores, alguns deles ligados à sua campanha, não tivessem sido presos antes, o senhor não teria sido prejudicado e a oposição sim teria sido bastante prejudicada. O senhor não acha que tem um problema nesse raciocínio, presidente? ${ }^{31}$

29 Denomino pergunta investigativa aquela que tem como objetivo examinar as afirmações do entrevistado por meio de um contra-argumento. Normalmente ela é formulada com a oração adversativa: "mas será que [...]?”. A pergunta investigativa resume o sentido de inquérito e está relacionada especialmente aos debates mais tensos.

30 Denomino "confirmação de hipóteses" as perguntas formuladas pelos jornalistas que têm como finalidade buscar a aprovação de seu ponto de vista pelo entrevistado. Normalmente, essas perguntas são formuladas como "você não acha que...?”, "diante desse quadro é possível afirmar $[\ldots]$ ?..".

31 Programa Roda Viva. 
O debate no Roda Viva muitas vezes assume um caráter tenso, o que confere dinâmica, agilidade e vivacidade ao programa. Um indício de que a conversação atingiu o clímax é que os participantes apresentam um comportamento mais passional - deixando transparecer irritação, desconcerto, revolta - e o ritmo das perguntas aumenta, provocando uma série de interrupções e sobreposições da fala. A sobreposição, portanto, é desejável e faz parte do jogo de poder que o Roda Viva põe em cena, uma vez que quando todos falam ao mesmo tempo estão competindo pelo direito à palavra e, consequentemente, pelo poder do discurso. Expressões como "deixa eu entrar nessa discussão aí", "desculpe um momentinho", "só um pouquinho, senadora" são formas que os enunciadores encontram para invadir o discurso do entrevistado, que se defende dizendo "deixa só eu terminar aqui”, "agora eu quero responder a pergunta de [...]". Entrevistadores e audiência compactuam com uma postura mais controladora do jornalista, o que permite que comportamentos, como aumento do tom de voz, aproximação corporal ao entrevistado, interrupção da resposta e monopólio da palavra, se justifiquem retoricamente e indiquem para o telespectador que o debate é intenso e aprofundado.

Para legitimarem seu papel de vigilância, os jornalistas chegam ao Roda Viva bem preparados, dispondo de dados estatísticos, declarações de fontes oficias divulgadas pela mídia, declarações do próprio entrevistado e informações adicionais a fim de entrarem na arena com argumentos suficientemente convincentes para a batalha discursiva que irá se travar ali. Por isso, muitas vezes os jornalistas se credenciam ao mostrar para a audiência que sua reivindicação diante do entrevistado é embasada numa apuração anterior à cena, por meio de enunciados como "nós conversávamos aqui, antes do programa [...]"32. A TV Cultura corrobora com essa atitude fornecendo previamente aos entrevistadores convidados um material contendo os principais aspectos do assunto e do entrevistado da rodada, o que permite que eles entrem no debate munidos de informações adicionais e com perguntas já elaboradas, o que desequilibra a conversa e põe os entrevistadores em posição de vantagem. O professor

32 Alexandre Machado, programa Roda Viva, edição de 16 out. 2006. 
Valdemar Setzer chamou a atenção para essa desigualdade no ingresso à conversação, ao responder à pergunta do jornalista Caio Túlio Costa: "Caio, você está numa situação de vantagem em relação a mim: eu não li os seus trabalhos e você se baseou nos meus [risos] que, aliás, estão na internet", ao que o jornalista retruca dizendo "sim, eu citei tudo que o senhor falou aqui" ${ }^{33}$, como se o acesso a informações anteriores pusesse os dois em desigualdade. O Roda Viva deixa transparecer o trabalho da equipe de produção do programa, cuja função é fornecer aos entrevistadores informações suficientes para que eles ocupem o lugar de vigilância.

O inquérito é o veículo pelo qual a verdade pode ser trazida à luz e, na "roda viva" da TV Cultura, o apresentador possui um lugar privilegiado no contexto comunicativo do programa para assegurar que as informações trocadas sejam verídicas, o que também reforça o trabalho da equipe de produção que dá sustentação a seu papel. Durante o período analisado, o único momento em que o apresentador prestou algum esclarecimento foi quando o deputado federal José Carlos Aleluia (então PFL, atual Partido Democratas) forneceu informações inverídicas para sustentar suas opiniões, enquanto discutia com a deputada Ideli Salvatti (PT):

José Carlos Aleluia - Imagino o que é que a dona Vilma de Castro está pensando. Ela e os pais daquele eletricista brasileiro que foi metralhado lá em Londres [referindo-se a Jean Charles de Menezes (1978 - 2005), imigrante brasileiro confundido com um homem-bomba e morto no metrô de Londres pela polícia britânica], o eletricista foi para Londres porque não tinha emprego, senadora. Ele foi ser eletricista lá porque aqui não tem emprego.

Imagino o que é que a dona Vilma de Castro está pensando. Ela e os pais daquele eletricista brasileiro que foi metralhado lá em Londres [referindo-se a Jean Charles de Menezes (1978 - 2005), imigrante brasileiro confundido com um homem-bomba e morto no metrô de Londres pela polícia britânica], o eletricista foi para Londres porque não tinha emprego, senadora. Ele foi ser eletricista lá porque aqui não tem emprego. 
Ideli Salvatti - “[interrompendo] Ele foi quando?”

José Carlos Aleluia - "No teu governo".

Ideli Salvatti - "No meu governo?”

José Carlos Aleluia - “Como estão indo os jovens brasileiros. O único lugar em que jovem brasileiro encontra emprego é no aeroporto [...]”.

Paulo Markun - "[No início do quinto bloco] Queria antes de mais nada registrar aqui que Jean Charles de Menezes estava em Londres desde o governo Fernando Henrique Cardoso [... $]^{3} \cdot{ }^{34}$

No Roda Viva, o apresentador concede sua opinião como argumento para a formulação de perguntas. Assim, há uma aparente objetividade que contrasta com o caráter adversativo das questões direcionadas ao entrevistado. Na dinâmica conversacional, o controle da distribuição dos turnos de fala ocorre, apenas, no início e encerramento dos blocos. Sendo assim, cabe ao apresentador abrir e fechar as trocas, deixando o restante do processo de construção da conversa aos entrevistadores e entrevistados que possuem liberdade de tempo para formular seus argumentos. A intervenção dos demais mediadores na conversação do Roda Viva permite a mudança de assuntos e a inclusão de aspectos novos imprevistos pelo apresentador. Assim, o programa distribui o papel de construção do debate entre todos os entrevistadores. Ao apresentador, cabe o papel de enquadrar a temática e a própria entrevista por meio da pergunta de abertura ${ }^{35}$, que visa destacar os aspectos que irão conduzir a conversa naquele bloco, ao menos inicialmente, permitindo que o entrevistado formule ideias a partir de argumentos fornecidos pelo apresentador:

Paulo Markun (a Tariq Ali ) - Eu queria começar pelo seguinte. O senhor acha que é possível conciliar literatura e militância política? Porque é uma longa discussão no mundo. Houve época que era muito valorizado, momentos em que se considerava que não havia

34 Programa Roda Viva, edição de 21 ago. 2006.

35 A formulação da pergunta de abertura cabe, exclusivamente, ao apresentador. Ele só abdica desse papel quando é para introduzir uma pergunta dos telespectadores. 
ligação possível - uma coisa é uma coisa e outra coisa é outra coisa

- e o senhor faz ambas. É possível haver essa conciliação? ${ }^{36}$

A pergunta de Paulo Markun a Tariq Ali não apenas diz sobre o que os participantes devem falar durante a conversa, mas indica o modo como Tariq Ali é inserido no programa: a partir de sua militância política, e não apenas na sua atividade como escritor. Sendo assim, não interessa ao programa o estilo textual de Ali, a construção de narrativas, o processo de distribuição dos livros - embora sua vinda ao Brasil estivesse vinculada à Festa Literária Internacional de Parati -, mas sim as questões que contextualizam suas obras - as contradições entre o mundo ocidental e o oriental - e será esse o assunto abordado durante a conversa. A preferência do programa pela atuação política do convidado demonstra o tom do Roda Viva no cumprimento do papel de vigilante e de formador de opiniões.

\section{POSICIONAMENTO DA AUDIÊNCIA}

O Roda Viva lança mão de um contexto comunicativo que visa colocar o telespectador numa posição de permanente atenção à conversação. Pelo seu horário de exibição, o programa concorre com filmes, programas de auditório e programas jornalísticos, e seu diferencial no fluxo televisivo é se constituir uma alternativa a uma programação voltada majoritariamente ao entretenimento. Para atrair o telespectador e mantê-lo preso durante toda a transmissão do programa sem ceder ao zapping, o Roda Viva exige que o telespectador acompanhe todos os meandros do debate para que não haja prejuízo de sua compreensão e ele possa formular sua própria opinião de maneira mais consistente.

As estratégias de captura da audiência se dão desde o início do programa, quando o apresentador fornece, no primeiro bloco, algumas informações contextuais sobre o convidado do dia:

Paulo Markun - Boa noite. Ela nasceu em Alagoas, num lugar chamado Pão de Açúcar que de doce só tem o nome. Criada no sertão alagoano, foi trabalhadora rural, sindicalista e fez carreira política 
no Partido dos Trabalhadores. Com marca pessoal forte, tornou-se uma das mais aguerridas mulheres a chegarem ao Congresso Nacional. Rompida com o PT há dois anos, agora se lança à corrida presidencial. O Roda Viva, que vem entrevistando os principais pré-candidatos à eleição presidencial deste ano, conversa esta noite com Heloísa Helena, pré-candidata à Presidência da República pelo PSOL, Partido Socialismo e Liberdade. O Roda Viva começa em um instante. ${ }^{37}$

Após a inserção dos patrocinadores do programa, o Roda Viva apresenta novamente o convidado da rodada através de um VT com narração em off, contendo os principais elementos sobre a carreira e a vida pública do entrevistado:

Narrador - Sempre envolvida no movimento sindical, popular, rural e indigenista, Heloísa marcou carreira não só pela postura, como pela disposição para enfrentar qualquer polêmica. Heloísa Helena Lima de Moraes Carvalho, 44 anos, nasceu em Pão de Açúcar, sertão de Alagoas, onde começou a trabalhar como bóia-fria com a família. Mais tarde, na capital, em Maceió, se formou em enfermagem com pós-graduação em epidemiologia. Começou a carreira política em 1990, no Partido dos Trabalhadores. Foi eleita vice-prefeita de Maceió em 1992 e deputada estadual dois anos mais tarde. Em 1998, tornou-se a primeira mulher eleita para o Senado por Alagoas, durante o mandato destacou-se no combate à política neoliberal do presidente Fernando Henrique Cardoso. Manteve a oposição ao governo Lula e acabou sendo expulsa do antigo partido. O primeiro grande confronto aconteceu quando recusou-se a apoiar a indicação de Henrique Meirelles para o Banco Central. Pouco depois, rejeitou o nome de José Sarney para a presidência do Senado, confrontando mais uma vez a direção petista. Fez críticas à política econômica do governo e criou nova crise quando se opôs ao projeto de reforma previdenciária. Foi punida e, finalmente, expulsa do PT em 2003, mas não deixou a política. Em 2004, ao lado de outros parlamentares também

37 Programa Roda Viva, edição de 12 jun. 2006. 
afastados, ajudou a fundar PSOL e é pelo novo partido que Heloísa

Helena disputa a presidência. ${ }^{38}$

No início de cada bloco, o programa recria estratégias para situar o telespectador na emissão, seja pelo texto verbal do apresentador, que relembra quem é o entrevistado do dia, seja por um VT com narração em off ou com imagens dos trabalhos mais significativos do personagem central do programa. Com exceção desses momentos, o Roda Viva pouco fornece informações contextuais sobre os assuntos que surgem na conversação, cabendo ao telespectador completar as lacunas deixadas pelo programa com informações que já possui através do acompanhamento constante da imprensa. Deste modo, o programa requer um amplo repertório cultural, uma vez que pressupõe que o telespectador já conheça os assuntos que surgem nas falas dos participantes. Mesmo as charges de Caruso promovem esse tipo de interpelação da audiência, uma vez que solicita, primeiro, que a audiência esteja atenta ao programa para interpretar os desenhos que capturam momentos específicos do debate. As charges, muitas vezes, tratam de uma situação extramidiática, com personagens que estão fora da cena, mas que se relacionam com os assuntos abordados.

O processo de edição do programa, que utiliza quadros longos, de aproximadamente trinta segundos, podendo chegar a um minuto, sugere que o telespectador assuma uma postura de reflexão e atenção irrestrita à fala dos enunciadores. Enquanto o convidado ou o jornalista desenvolve seu pensamento, as três câmeras do Roda Viva, situadas no nível da arquibancada, o capturam em plano americano, deixando visíveis: as mãos, a fim de mostrar a gesticulação que complementa a fala ${ }^{39}$, e a bancada, que exibe as anotações e documentos dos entrevistadores. O quadro fechado no falante e o corte seco do enunciador para o enunciatário criam um efeito de proximidade entre os interlocutores e o telespectador. Poucas vezes a câmera do Roda Viva não focaliza o enunciador

38 Programa Roda Viva, edição de 12 jun. 2006.

39 A exibição da gesticulação confere maior autenticidade à conversa, pois remete às práticas da vida cotidiana. 
que está com a palavra, mas quando o faz é sempre para mostrar atividades que evoquem uma postura de atenção e reflexão: o interlocutor assentindo com a cabeça enquanto o convidado fala, a plateia registrando a entrevista no twitter, as charges de Paulo Caruso. Através desse jogo de enquadramentos, a equipe de edição e os diretores do Roda Viva criam, por meio dos recursos da linguagem televisiva, um discurso do programa, discurso este que envolve o uso da imagem articulado com o que está sendo dito. Na entrevista com o professor Valdemar Setzer ${ }^{40}$, o Roda Viva intercalou a imagem do entrevistado, que falava sobre a ingenuidade das crianças para discernirem o conteúdo da internet, com imagens de uma charge satírica de Paulo Caruso ilustrando uma criança na frente de um computador como uma marionete. Em seguida, quando Valdemar Setzer fala sobre impedir o acesso juvenil aos sites, a câmera do Roda Viva mostra uma twitteira, em primeiro plano, digitando um texto na internet. A câmera vai abrindo o quadro e fazendo uma pan até que se veja todo o cenário do programa a partir do ponto de vista da participante conectada à internet. A imagem demonstra o lugar privilegiado que ela possui para observar aquela cena e relatá-la aos demais participantes que não estão presentes no programa, o que lhe confere legitimidade para construir suas ideias. Sendo assim, o Roda Viva apresenta, nesse momento, um contradiscurso ao do entrevistado, de que a internet pode ser usada com fins produtivos, como o programa busca fazer.

\section{TRANSFORMAÇÕES NA ARENA}

Em seus mais de vinte anos, o Roda Viva orgulha-se pelas mais de mil entrevistas realizadas que retratam "momentos e fatos importantes das mais diversas áreas do conhecimento: artes, política, economia, cultura, esportes, educação e saúde" ${ }^{41}$. Essa história e a credibilidade alcançada ao longo dos anos não permitiram, porém, que o programa se estabilizasse numa estrutura perene. Ao contrário, o próprio Roda Viva, enquanto espaço midiático, promove modificações com vistas a acompanhar as

$40 \mathrm{Em} 1^{\circ}$ dezembro de 2007.

41 Informações do site da TV Cultura, capturado em 20 abr. 2009. 
transformações sociais e as expectativas do público. Nesse sentido, duas mudanças significativas têm implicações na construção do programa e merecem ser enfatizadas: a exploração dos aspectos pessoais do entrevistado e a ênfase na interatividade por meio das novas tecnologias.

O Roda Viva se construiu com base nos aspectos relacionados à vida pública de seus entrevistados, rechaçando uma construção de sua credibilidade por meio de um vínculo íntimo entre os participantes da conversação posta em cena. No entanto, quando o centro da arena é ocupado por um personagem que tem boa aceitação popular, o Roda Viva explora certos elementos de sua vida pessoal que não necessariamente têm a ver com a carreira e a atuação social que o levou para o programa. Contrariamente ao que acontece com a esfera política, a qual o programa trata com desconfiança, quando os personagens que ocupam o centro da roda são agentes promotores da cultura e da cidadania, agentes que fazem o país ser melhor, que promovem uma projeção positiva do Brasil no mundo, estes são tomados como parâmetro de conduta e de ação social, e sua biografia é usada como exemplo para os telespectadores. $\mathrm{Na}$ entrevista concedida pelo ator Wagner Moura ${ }^{42}$, a apresentadora Lílian Witte Fibe enquadrou boa parte do último bloco nos aspectos pessoais do entrevistado, por meio de perguntas como

- [...] falando em família, um assunto que a gente acabou não abordando aqui é a tua admiração pelo teu pai. Queria que você contasse a história dele. Você fez um filme por causa dele e, para minha surpresa, lendo aqui sobre tua vida, o teu pai, uma pessoa simples como é, fez questão de se formar em direito e ficou preocupado com a educação. Você tem uma irmã médica? [...] Os dois são formados em curso superior? Conta isso? ${ }^{43}$

A insistência da apresentadora para que o ator fale sobre sua biografia revela uma mudança no enfoque do programa, que passa a usar a vida pessoal dos entrevistados para estreitar laços de proximidade com a audiência. Por outro lado, enfraquece o programa do ponto de vista da

42 Programa Roda Viva, edição de 29 set. 2008.

43 Programa Roda Viva, edição de 29 set. 2008. 
promoção de um debate, pois a vinculação com a biografia do ator não pretende a formulação de um argumento, ela entra como dado curioso. Embora o emprego de perguntas intimistas ${ }^{44}$ possa direcionar o programa ao tratamento de questões sociais mais amplas ${ }^{45}$, no caso da biografia de Wagner Moura, ela se esgota em si mesma, não servindo nem mesmo para levar o público a compreender suas opções como ator.

Segundo Mark Deuze (2005), dois aspectos emergentes do jornalismo contemporâneo podem modificar sua forma de produção: o multiculturalismo e a multimidialidade. Segundo o autor,

[...] a combinação das técnicas de controle do conjunto de notícias e transmissão das histórias em todos os formatos mediáticos [...], assim como a integração de tecnologias digitais de transmissão combinadas com a reconcepção da relação entre produtor e consumidor das notícias tende a ser um dos maiores desafios encontrados pelos estudos do jornalismo e seu ensino no século XXI. (DEUZE, 2005, p. 451)

É notável contemporaneamente que boa parte dos programas televisivos possui um site na internet que fornece informações básicas sobre pauta e programação, permite a recuperação de vídeos e, em alguns casos, possibilita a interação com a audiência. Assim, o ato de assistir a um programa não se restringe à recepção televisiva, mas envolve a relação com outras mídias que o complementam. No Roda Viva, o uso de tecnologias tem ampliado as possibilidades receptivas para, cada vez mais, incluir o público na conversa.

44 Perguntas intimistas são as que procuram levar o convidado à confissão de segredos, à partilha de emoções. Por meio de formulações como "foi difícil passar por isso?”, "o que você sentiu quando $[\ldots]$ ?.", "vocêtem medo?".

45 Um exemplo disso foi a pergunta de Luiz Carlos Azedo a Heloísa Helena: - "durante, praticamente, toda sua vida política, a senhora apostou num projeto do PT, e na candidatura do presidente Lula, na eleição do presidente Lula como, vamos dizer assim, forma de viabilizar tudo isso que a senhora está defendendo hoje. E, há dois anos, houve este rompimento. Eu não acredito que tenha sido unilateral, quer dizer, a senhora não saiu, foi expulsa, mas não foi unilateral, foi expulsa porque se insubordinou à orientação do PT. Mas esse processo deve ter sido uma coisa longa, dolorosa. A senhora poderia falar um pouco disso, como foi esse rompimento, essa decepção?”. Programa Roda Viva, edição de 12 jun. 2006. 
Uma das características mais marcantes do Roda Viva, desde seu surgimento, foi a possibilidade de constituir-se num fórum público dos assuntos, permitindo que a audiência tivesse voz no interior do programa. Segundo a revista Veja de 25 fev. 1987, além de perguntas gravadas previamente, o Roda Viva permitia que os telespectadores fizessem perguntas ao vivo por telefone. Assim, o semanário da TV Cultura sempre possibilitou que os telespectadores também tivessem acesso aos atores sociais presentes em sua arena por meio de telefone, fax e e-mail, à medida que as tecnologias de comunicação progrediam. Na versão anterior a 2008, o público era representado no programa por meio da plateia, formada por estudantes universitários, jornalistas, advogados, representantes de partidos e de sindicatos que assistiam ao debate, sem direito à palavra. Ao final de cada bloco, a plateia era apresentada e exibida à audiência. Além disso, o programa gravava um VT com perguntas de pessoas comuns em locais públicos, de modo que a audiência, de fato, tivesse voz e lançasse suas preocupações aos convidados do programa. A representação do povo incluía taxistas, cabeleireiras, professores, representantes comunitários que apareciam creditados durante a transmissão do Roda Viva. Essa tentativa de representação popular no interior do contexto discursivo do programa visava sustentar a proposta de um jornalismo público que a emissora que o transmite carrega, mas também obedecia a uma seleção por parte da produção do programa. Sendo assim, não era qualquer pessoa que entrava na plateia do Roda Viva, mas aquelas que possuíam alguma relação com o convidado. Na entrevista com Heloísa Helena, um dos participantes da plateia foi o deputado federal pelo PSOL de São Paulo, e um dos entrevistados que falavam do exterior do programa era o líder comunitário de São Paulo, Vanildo Moreti. Embora não tenha visibilidade midiática, os interesses do líder comunitário convergem para as propostas da entrevistada do dia. Sendo assim, há um processo seletivo de quem participa e quem não tem direito a voz no Roda Viva. Os membros da plateia não se engajam no debate, cabendo-lhes o papel de espectadores da conversa.

Em 2008, as formas de inserção da audiência no programa sofreram modificações que, se por um lado foram otimizadas, por outro ampliaram 
a lacuna existente entre a emissão e seu público. Ao invés de exibir as próprias pessoas fazendo suas perguntas, o Roda Viva adicionou à bancada de mediadores uma repórter da TV Cultura responsável por ler as perguntas que os telespectadores enviam por e-mail ou fax. Sendo assim, o programa midiatiza a voz da audiência, que não possui acesso direto à conversa. Na edição de $1^{\circ} / 12 / 08$, a jornalista Carmem Amorim foi responsável pelo contato do público com o programa:

- [...] eu tenho uma pergunta aqui, aliás duas, do C.H., de Anápolis, Goiás, que pede para o senhor fazer um comentário sobre o impacto da lan house na vida das crianças e adolescentes, né. E o que o senhor acha das redes sociais: orkut, por exemplo, qual é o impacto que essas redes podem ter na vida dessas crianças e adolescentes. ${ }^{46}$

Assim, não é a pessoa comum que se engaja no debate promovido pelo programa, mas um representante do campo jornalístico que lhe dá voz.

Por outro lado, o site do Roda Viva na internet permite aos usuários acessarem os bastidores do programa - reportagens feitas com os entrevistadores sobre suas expectativas do debate -, assistir ao programa na web, enviar perguntas, participar de um bate-papo durante a transmissão e acompanhar a produção das charges. Assim, o próprio telespectador do programa pode obter mais informações sobre os assuntos e o convidado, o que o coloca numa posição mais autorizada no debate, buscando informação para formar sua opinião por vários canais. As mensagens partilhadas via twitter pelos participantes na plateia do estúdio corroboram para promover um debate no âmbito social, fora dos limites televisivos, embora fomentado por eles. Sendo assim, o Roda Viva amplia sua atuação e permite que se crie uma comunidade de interesses aduzida pela conversação que o programa põe em cena.

Desta maneira, o Roda Viva aposta na convergência para alcançar uma audiência mais vasta e confirmar o lugar de debate público que reivindica na construção de seu estilo. Os ideais de participação e inclusão do público, que reforçam aspectos democráticos, são lançados para o espaço 
virtual, que permite liberdade de acesso para participantes diversos, mas com alcance reduzido.

Essas mudanças na arena apontam para transformações que o programa efetua no subgênero. O Roda Viva é o programa de entrevistas há mais tempo em exibição no país. Por conta disso, ele preserva certos elementos ao mesmo tempo que inova outros, efetuando um avanço no subgênero. A conservação do cenário nos mesmos moldes, a proposta de um "debate vivo", como salientou a revista Veja de 25 fev. 1987, são elementos que criam familiaridade entre o programa e a audiência e, de certo modo, dão um sentido de estabilidade, conservando os aspectos que asseguram a qualidade do programa em todos esses anos. Por outro lado, o Roda Viva não deve ser compreendido como se estivesse estático, mas, pelo contrário, ele se adapta para incorporar o novo: a nova tecnologia, as novas formas de incluir a audiência, os novos personagens da cena pública. Essas inovações promovem um retorno ao nome do programa, à vivacidade da roda, que permanece ativa, se reconfigurando em torno do novo.

\section{REFERÊNCIAS}

BRAGA, José Luiz. Roda Vida - uma encenação da esfera pública. In: ENCONTRO ANUAL DE NÚCLEOS DE PESQUISA DA INTERCOM, PJO - NÚCLEO DE JORNALISMO, 2006, Brasília, DF. [Anais...] Brasília: [s.n.], 2006.

BARBOSA, Marialva. História cultural da imprensa: Brasil, 19002000. Rio de Janeiro: Mauad, 2007, 262p.

DEBATE vivo: inovações nas entrevistas do programa Roda Viva. Veja, Rio de Janeiro, n. 964, , p. 113, 25 fev. 1987.

DEUZE, Mark. What is journalism? Professional identity and ideology of journalists reconsidered. Journalism, London, v. 6, n. 4, p. 442-464, 2005.

EKSTRÖM, Mats. Information, storytelling and attractions: TV journalism in three modes of communication. Media, Culture $\mathbb{E}$ Society, 2000, Vol. 22, 465-492. 
GUERRA, Josenildo Luiz. O percurso interpretativo na produção da notícia. 2003. 258f. Tese (Doutorado em Comunicação) - Programa de Pós-graduação em Comunicação e Cultura Contemporâneas, Universidade Federal da Bahia, Salvador. MELO, José Marques de. A opinião no jornalismo brasileiro. Petrópolis: Vozes. 1985.

RODA VIVA. Disponível em:_ http://www2.tvcultura.com.br/ rodaviva/sobreoprograma.asp>. Acesso em 20 abr. 2009.

SANTOS, Jair Fernandes de Melo. Modos de endereçamento em dois programas de entrevista brasileiros: um estudo do Roda Viva e do Gordo a Go-Go. 2005. 101 f. Monografia (Trabalho de conclusão de curso para obtenção de grau de bacharel em Comunicação Social) - Faculdade de Comunicação Social da Universidade Federal da Bahia, Salvador.

SILVA, Fernanda Mauricio. A conversação com estratégia de construção de programas jornalísticos televisivos. 2010a. 293f. Tese. (Doutorado em comunicação) - Programa de Pós-graduação em Comunicação e Cultura Contemporâneas, Univesidade Federal da Bahia, Salvador.

SILVA, Fernanda Mauricio. Do debate público ao cara-a-cara: Marília Gabriela comanda o Roda Viva. Disponível em: <http:// telejornalismo.facom.ufba.br.> Acesso em 15 nov. 2010b.

TRAPANOFF, Fabíola. Roda Viva: a arena da notícia. Revista Imprensa, 19 out. 2004. Disponível em: <http://portalimprensa. uol.com.br/portal/ultimas_noticias/2004/10/19/imprensa5243. shtml>. Acesso em 02 maio 2009.

VERÓN, Eliseo. Esta ahí lo veo, me habla. Tradução Maria Rosa Del Coto. Enunciacion et cinema, Revista Comunicativa, Paris, n. 38, 1983. 


\title{
Estratégias de endereçamento da primeira versão do Jornal da MTV
}

\author{
Juliana Freire Gutmann
}

\section{INTRODUÇÃO}

O Jornal da MTV estreou no dia 08 de março de 2002 como um programa semanal com uma hora de duração, o que lhe garantia tempo para um maior aprofundamento dos temas abordados, tendo espaço para dois ou mais entrevistados por edição․ Exibido sexta-feira às $21 \mathrm{~h}$, faixa de horário nobre da emissora, o programa era apresentado pelo radialista Fábio Massari, figura conhecida no cenário fonográfico pelo seu perfil crítico e amplo conhecimento musical, fatos que lhe renderam o apelido de Reverendo ${ }^{2}$. No âmbito desta análise, o Jornal da MTV é identificado como um programa de jornalismo temático, isto é, trata-se de um produto televisivo voltado para uma especialização midiática: o jornalismo musical. Junto com as publicações sobre música, revistas segmentadas, suplementos culturais dos jornais impressos, programas de rádio e sites

1 Apesar de preservar o nome, Jornal da MTV, o programa é reconfigurado a cada ano. Em 2003, passou a ser veiculado de segunda a quinta à oh e investiu na atuação de dois apresentadores, Edgard Picolli e Rafael Losso. Uma terceira mudança ocorre em 2005, quando Sarah Oliveira assume, ao lado de Rafael, a apresentação do programa, que permaneceu no mesmo local na grade de programação, mas ganhou uma edição dominical intitulada Jornal da MTV Semana Rock, apresentada por Edgard. No ano de 2006, o programa muda novamente de apresentadores e começa a ser comandado por Leo Madeira e Carla Lamarca. Em 2007, Carla Lamarca é substituída por Luisa Micheletti, que passa a apresentar o Jornal, agora diário e ao vivo, ao lado de Leo Madeira. A presente análise, no entanto, refere-se apenas à primeira versão do programa, exibida em 2002. A observação levou em conta sete edições do jornal: o programa de estreia, que foi ao ar no dia 08 de março de 2002, e mais seis edições mensais: três exibidas no primeiro semestre de 2002 (12 de abril de 2002, 24 de maio de 2002 e 07 de junho de 2002), e três veiculadas no segundo semestre (13 de setembro de 2002, 25 de outubro de 2002 e 08 de novembro de 2002).

2 Nome dado, normalmente, a líderes religiosos que merecem "reverência”. Dessa forma, a denominação se refere ao reconhecimento de uma hierarquia, a uma forma respeitosa de se dirigir àquele que merece ou deve ser honrado. 
especializados no assunto, o Jornal desempenharia o papel de publicizar e contextualizar artistas, bandas e cenas tendo em vista o significado cultural de tais produções. Coube, portanto, à MTV encontrar um modo de adaptar tal função, mais difundida na mídia impressa, às especificidades do ambiente televisivo, numa tentativa de encontrar um modo de fazer o que se poderia chamar de telejornalismo musical.

\section{PRIMEIRA ESTROFE - AS PISTAS DO PROGRAMA DE ESTREIA}

"Vamos lá, merda para a gente. Começa neste exato momento o Jornal da MTV. Uma hora de informação com um bilhão na sua emissora musical". A frase de estreia do programa, pronunciada no ritmo frenético da locução de Fábio Massari, antecipa pistas sobre o clima que se pretende instaurar. O tom da enunciação é introduzido pela vinheta do programa. Um robô formado por 15 monitores de TV, preenchidos por diferentes imagens de videoclipes, corre sobre uma estrutura côncava branca que remete ao globo terrestre, tendo ao fundo um céu azul estrelado. O compasso do efeito sonoro, desenvolvido de modo acelerado, dita a velocidade do robô, que aumenta junto com o tempo da trilha até invadir a lateral da tela e congelar. A imagem de parte da estrutura desse boneco congelado no lado esquerdo da TV revela uma de suas asas que coincide com as asas das extremidades da logomarca do Jornal da MTV, agora inscrita no centro do quadro. Como estratégia de legitimação do pretendido cunho jornalístico do programa, o conceito da vinheta se ancora no binômio: informação e agilidade. O robô recheado de imag’ens corre, voa em direção ao telespectador. Assim como os dispositivos gráficos e sonoros criados para a vinheta, os enquadramentos, movimentos de câmera e o ritmo da narração do apresentador antecipam parte do acordo que se pretende estabelecer com a audiência. A atmosfera de velocidade proposta, portanto, é uma das estratégias de credibilidade do programa que se autointitula "jornal da televisão musical".

A temática do Jornal da MTV é, a princípio, materializada pelo ambiente onde se dá a enunciação: um cenário em forma de toca-discos. A "cápsula musical" - como o apresentador costuma caracterizar o estúdio - é projetada sobre um piso em formato de disco de vinil, supostamente acio- 
nado por uma "agulha" que funciona como bancada. A visualização completa deste ambiente marcado por figurativizações sonoras se faz por uma câmera posicionada no alto e em plongê (angulação de cima para baixo). A intenção aqui é reforçar o assunto em questão, como se a rotação do disco e a sucessiva emissão musical coincidissem com os 60 minutos do programa. Em contraposição a essa referência nostálgica ao LP de vinil, os outros elementos dessa espécie de fachada do Jornal conferem um ar de modernidade ao ambiente. O cenário é construído em camadas e tem fundo azul marinho. A lateral direita é composta por um painel vermelho com a logomarca do Jornal em azul e a bancada em forma de agulha, onde ficam as "recomendações do dia", CDs, DVDs, revistas de música e livros. No lado esquerdo do cenário, há um monitor de televisão, através do qual o apresentador conversa com seus convidados. Na parte frontal, um painel em tom azul claro é preenchido por discretas inscrições em branco dos protagonistas das notícias veiculadas: Planet Hemp, Racionais, Marisa Monte, Chemical Brothers, Jane's Addiction, Red Hot Chili Peppers etc.

O modo como os recursos da linguagem televisiva são utilizados para a ambientação do cenário sentencia parte de suas apostas hierárquicas e valorativas. O Jornal da MTV contempla determinados gêneros da música popular massiva, aqueles que transitam entre as referências clássicas do rock e as experimentações mais modernas da música eletrônica. O cenário ilustra esta dicotomia através da representação do LP, numa referência à sintaxe fundadora da música pop, em contraste com o telão e as estruturas metálicas do projeto arquitetônico. As produções fonográficas noticiadas, representadas no estúdio pelas inscrições no painel frontal, contemplam artistas nacionais e internacionais que dialogam com marcas genéricas do rock (Planet Hemp, Jane's Addiction, Red Hot Chili Peppers), mas também flertam com a MPB (Marisa Monte), com a música eletrônica (Chemical Brothers) e o Rap (Racionais). Os dispositivos discursivos presentes na fachada principal do Jornal, portanto, dizem sobre o que é pautado pelo programa e sobre o contexto comunicativo no qual se dará a mediação. 


\section{ENTRE A SALA DE AULA E O BACK STAGE}

As configurações discursivas através das quais se operacionaliza a interação do programa com o público se valem da construção de lugares de fala específicos para o sujeito enunciador (o Jornal da MTV representado pela figura de Fábio Massari) e enunciatário (o público-alvo personalizado pela audiência). As posições de fala que o apresentador e o telespectador ocupam no texto televisivo configuram o contexto comunicativo através do qual se dá a mediação e indicam o modo como o público deve se relacionar com o Jornal.

O Jornal da MTV representa a sua audiência a partir de uma posição hierárquica bastante definida. É como se os sujeitos enunciadores e enunciatários participassem de uma mesma "comunidade de conhecimento" (FRITH, 1998), aquela cujas referências se apoiam em traços genéricos da música popular massiva, mas tivessem graus de instrução distintos. A proximidade reivindicada com a audiência se ancora no recorte temático e na consequente partilha de gostos, hábitos e valores. Contudo, apesar desses interesses comuns, há uma forte marcação dos níveis de conhecimento entre texto e leitor, o que reforça a autoridade do mediador.

Essa marca do Jornal pode ser ilustrada pelos diversos momentos ao longo de uma mesma edição em que o apresentador recomenda para a audiência um determinado $\mathrm{CD}$, filme ou publicação sobre música. Massari mostra e indica o produto escolhido em tom de catequese, como se estivesse formando a audiência para o universo dos aficionados por música. Ele costuma introduzir as indicações de modo imperativo com frases do tipo: "Tem que ouvir", "Tem que ler" ou ainda "Tem que assistir”, que denunciam a autoridade do $\mathrm{VJ}^{3}$. No dia 07 de junho de 2002, Massari mostra a capa do disco da banda Unkle, após anunciar os "discos que saíram recentemente do forno" e diz: "Tem que ouvir Unkle, um dos projetos de um cara que a gente recomendou aí, o DJ Shadow" 4 (o artista estava entre os lançamentos citados na matéria anterior). Ao buscar

3 Video-jockeys. Os apresentadores da MTV são denominados VJs em referência aos DJs (Disc-jockeys), que são os responsáveis pela execução de músicas em clubes, festas e emissoras de rádio.

4 Jornal apresentado no dia 07 de junho de 2002. 
a legitimação da sua informação, também atesta o posicionamento dado aos seus interlocutores: "E você deve estar se perguntando, mas afinal de contas como é esse DJ Shadow? Eu mostro para vocês o sujeito na capa mais recente da revista inglesa The Wire" 5 (mostra a capa da revista, que é focalizada em close pela câmera). "DJ Shadow, um cara cultuadíssimo, e se tratando de bons sons eletrônicos, é com ele mesmo" ${ }^{\circ}$.

Essa situação, recorrente em todas as edições analisadas, coloca o apresentador em uma posição de mestre que tem legitimidade para dizer o que tem de ser feito porque "sabe mais" e tem o que "ensinar" à audiência. Em 25 de outubro de 2002, ao falar sobre o novo disco da $\mathrm{Na}$ ção Zumbi, refere-se ao produto como "verdadeiro clássico" e sentencia: "Nação Zumbi é o nome da banda, é nome do disco, saiu do forno e você tem que ter. Se você for comprar só três discos de música brasileira nesse ano, tem de faturar a Nação Zumbi" 7 . Em cenas como esta, o VJ costuma aparecer encostado na bancada, onde se encontram as suas indicações do dia. O efeito do zoom é utilizado para aproximar o produto do telespectador. Portanto, não é Massari que chega perto do consumidor para recomendar, mas este que se desloca em direção ao Reverendo.

A questão da autoridade do jornalista, daquele que tem legitimidade para falar sobre música, é fundamental para o entendimento dos processos enunciativos de um programa projetado na representatividade de um único condutor. Se, como sustenta Frith (1998), o crítico musical, juntamente com os fãs, é uma das principais vozes do jogo valorativo que dá conta da produção de sentido da música pop, o Jornal da MTV recorre à figura de Massari para preencher essa expectativa. Contudo, diferentemente do meio impresso, espaço por excelência do gênero denominado crítica, a mediação proposta se ancora em dispositivos discursivos próprios da linguagem audiovisual. Nessa perspectiva, a estratégia encontrada pelo programa é apostar em um mediador que faça as vezes do âncora, daquele que não apenas apresenta as notícias, mas também se

5 Jornal apresentado no dia 07 de junho de 2002.

6 Jornal apresentado no dia 07 de junho de 2002.

7 Jornal apresentado no dia 25 de outubro de 2002. 
comporta como comentarista, influenciando diretamente na linha editorial.

Através de Fábio Massari, o Jornal evoca uma proximidade com a audiência, mas não de modo a simular uma situação íntima. A cena criada, apesar de recorrer a certo grau de cumplicidade, aproxima-se mais de uma situação de "sala de aula", onde a troca comunicativa está sujeita a diferentes posições hierárquicas. A voz legitimada para relatar os assuntos é a do apresentador que, na tela, assume o papel de Reverendo, daquele que sabe sobre o que fala e, por isso, é autorizado a emitir juízos de valor sobre as produções, construir relações entre os temas, contextualizar bandas e cenas.

O amplo cenário oferece ao VJ maior mobilidade, permitindo que ele transite no espaço de um lado para o outro ou vá ao encontro de uma das câmeras. O plano mais utilizado é o americano (PA), que distancia o apresentador da tela de modo a ratificar os lugares de fala dos sujeitos da enunciação. O primeiro plano (PP) denota uma maior proximidade do apresentador em relação à audiência e é usado, geralmente, nas situações em que o VJ interpela o público. O close-up, que sugere uma intimidade ainda maior com o telespectador, é raro no programa. Esses posicionamentos corporais ajudam a modalizar o que é dito verbalmente e configuram um meio de aproximação ou distanciamento com o telespectador.

Massari também explora um maior contato com a audiência através de modalizações verbais que interferem de forma enfática na produção de sentido do programa. Nos programas jornalísticos mais convencionais, como o telejornal, mesmo olhando diretamente para a audiência, o mediador não se apropria do que fala, pelo contrário, esforça-se para não demonstrar envolvimento pessoal com o relato. Legitimado pelas especificidades da mediação musical e pelo consequente tom valorativo das coberturas, o Jornal da MTV recorre a um explícito posicionamento discursivo. Ora, se a produção de sentido no âmbito musical se ancora nos juízos de valor, e esses estão subjugados aos contextos discursivos dos quais fazem parte os seus atores, o investimento do programa é no sentido de se colocar frente aos fatos reportados. A mediação amparada no jogo valorativo origina um interessante efeito de imbricamento de 
papéis entre a fonte de enunciação (o programa ou a emissora) e sua figurativização (o apresentador). Ao invés de se apoiar em um não eu para atuar como um representante imparcial, o apresentador da Music Televison se dirige ao público através de um eu que fala por si ou pela emissora.

O investimento no eu individual é recorrente em todas as edições analisadas: "Eu tenho que recomendar $[\ldots]$ ", “[...] eu investiguei porque $[\ldots]$ ”, “[...] levou um papo comigo", "daqui a pouco eu quero falar de crítica $[\ldots]$ ”, "senta aí que eu vou contar [...]”. Nessa perspectiva, o delegado do discurso se faz confundir com as suas representações pessoais, esforçando-se para imprimir uma marca individual no processo comunicativo, ainda que esta esteja sempre vinculada não só a um macrodiscurso coletivo, o da MTV, mas, e principalmente, aos valores da comunidade de conhecimento na qual se sustenta a mediação. A segunda situação recorrente é o imbricamento entre as duas instâncias do sujeito enunciatário (o programa e sua figurativização). Assim, ao mesmo tempo em que o apresentador, retoricamente, coloca-se no texto verbal como sujeito individual, também apela para o eu coletivo, em referência à equipe do programa e à emissora: "a gente acha a banda muito bacana", "eles conversaram com a gente [...]", "a gente recomenda bastante esse disquinho [...]", "a gente apresenta agora para vocês $[\ldots]$ ".. etc.

O uso retórico de um eu individual ou coletivo é localizado, isto é, o programa e o VJ se posicionam explicitamente, mas a partir da comunidade de conhecimento da qual fazem parte junto com os telespectadores. O ritual de "gostos" e "desacordos" próprio da mediação musical, portanto, não é algo puramente subjetivo, mas reflete uma partilha valorativa. Nesse sentido, o nós também pode ser usado para evocar proximidades entre os interlocutores, incluindo a voz do enunciatário na do enunciador ("eu" + "tu”) e colocando os sujeitos no mesmo local enunciativo. O resultado desse novo imbricamento é uma sensação de parceria: "vamos conferir juntos aqui no Jornal da MTV", "a gente confere um aperitivo de I’m my do [...]", "vamos escutar o som do [...]", "para começar, vamos a Fortaleza $[\ldots]$ " etc. 
Para Simon Frith (1998), a legitimidade do jornalista especializado em música requer conhecimento técnico e histórico, mas também conhecimento sobre sua audiência, suas necessidades e valores. A autoridade de Massari depende da adesão do seu público, uma vez que é necessário estar minimamente iniciado para fazer parte do jogo comunicativo proposto e se incluir no nós (enunciador + enunciatário) proposto pelo programa. Esse engajamento requer um ouvinte que dialogue com o texto a partir de certos hábitos de consumo musical e televisivo. Além de um conhecimento prévio sobre o que se fala, a participação da audiência pressupõe partilha de valores. É a partir dessa adesão que o público se coloca como sujeito enunciatário do programa: aquele que divide interesses e gostos e está ávido por novas informações e referências sobre o significado cultural das produções musicais.

Mas, ainda que a interação com o Jornal se sustente em uma situação de partilha, os lugares dos sujeitos discursivos não se confundem no texto. Ou seja, apesar de o jornalista atuar no âmbito de uma comunidade de conhecimento, comportando-se também como um ouvinte, sua missão como crítico, aqui visto como âncora, é qualificar as obras e definir a experiência ideal para o seu público. (FRITH, 1998, p.67) No Jornal da MTV, tais expectativas são forjadas na figura de Fábio Massari, que é credenciado pelo programa e, supostamente, pela audiência para indicar e legitimar as produções. Assim, é também a partir desse lugar proposto para o enunciatário (de aficionado por música), que se configura o papel do mediador central do programa. O "Reverendo Massari" é autorizado pelos seus "companheiros" (os espectadores) a dissertar sobre os assuntos em pauta e também a discernir sobre o que "é bom" e o que "não é bom". Se, como sustenta Frith (1998), a produção de sentido da música pop passa pelos julgamentos ancorados em certas comunidades de sentido, aqui a mediação é sustentada pela mesma estratégia.

Esse status conferido ao apresentador também se vale da questão do acesso às fontes. A credibilidade conferida a Fábio Massari é sustentada pelo fato dele se colocar, no texto, como aquele que conhece os artistas e produtores do meio musical. Nesse sentido, o programa também simu- 
la uma situação de back stage $e^{8}$ partilhada por aqueles que transitam pelo mainstream e, por terem acesso aos bastidores do show business, conhecem as ingerências dos sistemas de produção e a intimidade dos artistas. No dia 24 de maio de 2002, para relacionar a entrevista com Jorge Ben Jor ao VT seguinte, uma das matérias da série de reportagens sobre a produção musical dos países com seleções na Copa do Mundo de 2002, Massari diz:

- Jorge Ben Jor é um amante do futebol e toda segunda-feira ele bate uma bolinha no Rio de Janeiro. Aliás, Ben Jor nem jogou no Rock Gol porque estava machucado. Segundo ele, depois de fazer um gol numa dessas peladinhas, pintou a contusão. Mas vamos girar o mundo da bola. Mais quatro sons de seleções que estarão na copa. ${ }^{9}$

O texto denuncia um grau de intimidade que o programa procura ter com suas fontes, também conferida em diversas passagens: “[...] vai tocar na intimidade do violão só para a gente aqui da casa" ${ }^{10}$, "e a gente cruzou com o Ricardinho [em uma referência informal ao cantor conhecido pelo grande público como Ritchie] no estúdio para saber mais sobre esse disco novo"11, "num momento bastante família, o baixista conversou com o Jornal da MTV no Rio de Janeiro"12. Nas respectivas matérias, o tom de intimidade é mantido: Jim Capaldi aparece muito à vontade com um violão na mão para mostrar trechos de uma canção inédita que compôs com George Harrison, Ritchie fala que a sua filha pequena foi o principal incentivo da sua volta aos estúdios e o baixista Canisso aparece junto aos seus três filhos e esposa para explicar a sua saída do grupo Raimundos.

O clima de intimidade entre mediador e fonte se torna explícito durante as entrevistas no estúdio, em que os interlocutores se comportam como pessoas próximas e simulam uma situação informal. Os entrevis-

8 Em seu sentido literal, o termo back stage significa "atrás do palco". No meio musical, é o jargão usado para o espaço onde, durante os concertos, circulam os artistas, produtores, equipes técnicas, empresários de gravadoras e jornalistas.

9 Jornal exibido em 25 de maio de 2002.

10 Jornal apresentado em 08 de março de 2002.

11 Jornal apresentado em 07 de junho de 2002.

12 Jornal apresentado em 08 de novembro de 2002. 
tados vão ao programa não apenas para falar sobre seu trabalho, mas, e principalmente, para se colocar, junto com Fábio Massari, como comentaristas dos fatos relatados. A intenção aqui é simular uma conversa cotidiana apoiada no ritual valorativo. Entrevistado e entrevistador não olham para a câmara, dirigem-se um ao outro, o que provoca distanciamento por parte da audiência. Nesse tipo de situação, o espectador não se coloca na posição de aluno, mas de alguém que tem o privilégio de flagrar uma conversa que parece se desenrolar independentemente da câmera.

Durante as entrevistas e debates, os interlocutores costumam se dirigir um ao outro de modo íntimo e cordial, por isso expressões como "meu amigo", "meu velho", "grande Massari” são recorrentes. O tom de cordialidade pode ser ilustrado pela entrevista com o crítico Luis Antônio Giron, na edição do dia 25 de outubro de 2002, assim anunciada pelo apresentador: "Na grande tela do Jornal da MTV, nós recebemos um verdadeiro ícone da crítica musical, Luis Antonio Giron. Salve Giron!”. O entrevistado responde: "Salve Reverendo!”. Giron, assim como os demais convidados presentes nas edições analisadas, funciona como o principal interlocutor de Massari, ao repercutir parte dos temas retratados durante o programa. Ao ser questionado sobre a crítica musical ("Você, há alguns anos, nos anos 90, era o cara que arrumava confusão, polêmicas, é mais ou menos por aí?"), o convidado recorre à identificação com o entrevistador: "[...] as polêmicas vêm por causa do debate de opiniões, né? E o crítico tem que opinar, não tem? Eu gosto de opinar, você gosta de opinar. A gente é viciada nessa cachaça de opinar [...]". O apresentador interfere:

Exatamente [...] eu me lembro de uma clássica, eu vou ter que lançar porque eu peguei aí nos meus arquivos, que é um título de uma matéria tirada do seu texto: 'Carlinhos Brown enfeitiça a platéia e ela dorme'. Esse é um clássico, heim? Sensacional! ${ }^{13}$

Nessas situações, os planos reforçam a presença dos interlocutores no mesmo quadro.

13 Jornal exibido em 25 de outubro de 2002. 


\section{A INSCRIÇÃO NA DIFERENÇA}

De modo sintomático com o fluxo audiovisual do qual faz parte, o Jornal da MTV se apropria de referências plásticas da cultura pop para construir seus relatos, especialmente, do caráter efêmero e dinâmico do videoclipe. É dessa maneira, atribuindo aos formatos visuais características dos textos sonoros, que o programa busca construir uma marca de reconhecimento na configuração formal das suas histórias. As matérias são editadas conforme a essência do videoclipe: a fusão entre música e imagem. Os cortes de edição dos VTs são feitos no beat ${ }^{14}$ de uma determinada música, buscando uma visualidade de natureza mais rítmica. A trilha sonora é abundantemente explorada nas edições, funcionando inclusive como pano de fundo para as sonoras. Nesse mesmo sentido, os sobe-sons são utilizados de modo deliberado entre os depoimentos das fontes de informação. A intenção é utilizar essa forma visual da canção como uma espécie de frame estético para noticiar a música.

Em seu aspecto visual, o videoclipe constitui uma convergência de recursos e linguagens que se apropria de elementos do cinema, da fotografia, da publicidade etc. Há clipes cujas imagens foram produzidas em película e que, por isso, possuem granulação e luminosidade específicas do cinema, outros utilizam imagens infográficas, animações, fotografias ou ainda são produções híbridas que passeiam por diversas linguagens. O Jornal da MTV leva em conta essa tendência plástica: brinca com o grafismo, com a inserção de fotografias, usa diferentes texturas e cores na construção de seus relatos.

Segundo Goodwin (1992, p. 76), a quebra do sistema realista de endereçamento no videoclipe, que costuma se apresentar como uma narrativa sintética e fragmentada, é uma convenção de performance da música pop, o que significa que o formato é autorizado, pelas especificidades de certos estilos musicais, a investir em subversões estruturais, ainda que essas estejam ancoradas em convenções e marcas genéricas. O autor des-

14 Batida. De acordo com Roy Shuker (1999), o ritmo é o padrão de batida presente na maior parte das formas de comunicação e se refere a suas variações de tempo, o qual é identificado como o "andamento da batida" (1999, p. 34). O autor afirma que, na música, os ritmos costumam ser repetitivos e seguir um padrão constante. 
taca que as canções são formas breves com duração de cerca de três minutos, sustentam-se no alto grau de repetição nos espaços midiáticos, na reiteração de elementos na estrutura formal (versos, pontes, refrões e solo) e nas referências a outras obras. Nesse sentido, Goodwin (1992, p. 84) defende que:

Os videoclipes desafiam o debate sobre o texto clássico e realista derivado dos estudos de cinema em dois sentidos. Primeiro, a música arquiva resoluções a partir da repetição de modo mais intenso do que um desenvolvimento linear. Segundo, as letras das canções geralmente operam sem comprometimento com um desenvolvimento temporal - e mesmo que uma história seja contada do começo ao fim através da letra, o método de contá-las é completamente diferente dos encontrados na televisão ou no cinema.

Assim como os vídeos musicais, as estruturas e recursos técnicos utilizados nas matérias do Jornal da MTV se espelham nos apelos das canções, investindo na reiteração de elementos na estrutura (sobe som/ sonora/ sobe som / sonora/ sobe som), nos expedientes estéticos (texturas, efeitos gráficos) e na fragmentação da edição no lugar de um desenvolvimento linear do relato.

Goodwin (1992, p. 109) também sustenta que grande parte do investimento emocional dos ouvintes com os videoclipes se dá via identificação com as personalidades televisionadas. Nesse caso, a centralidade da voz na música pop é expressa visualmente através do close-up, utilizado como uma adequação das convenções da gramática televisiva. Portanto, ainda que resguarde o seu caráter jornalístico, o programa, assim como o videoclipe, favorece a publicização da imagem do artista, seu estilo, suas influências, seu modo de vestir, sua performance. Os enquadramentos geralmente aproximam o personagem retratado do espectador e as imagens em que o artista aparece atuando são usadas exaustivamente.

O Jornal da MTV utiliza tipos de planos e angulações que borram as convenções televisivas dos telejornais. Ao mesmo tempo em que foca o personagem em primeiro plano, a partir de um quadro parado sem angulação, o programa pode recorrer a um subversivo olhar que coloca o sujeito de fala fora de enquadramento ou de perfil. As angulações de câmera 
também são bastante exploradas, o que possibilita que a fonte seja focada a partir de diversos pontos de vista.

\section{O POP EM PAUTA}

Considerando o jornalismo como uma esfera de mediação simbólica que põe em relação determinados acontecimentos, selecionados a partir de critérios de verdade e relevância (GUERRA, 2004), e um público para quem esses eventos possam ser considerados importantes, é possível afirmar que, como programa temático de cunho jornalístico, o Jornal da MTV tem a função de informar sobre aquilo que considera relevante em uma determinada esfera da realidade, o campo musical. Ao informar sobre as manifestações musicais, o Jornal também responde por um processo valorativo. O ato de noticiar o lançamento de um disco e valorá-lo não significa, no entanto, apenas um modo de expressar preferências pessoais, mas uma adequação a uma determinada comunidade de conhecimento. O apresentador está ali para manter o telespectador informado, mas sempre a partir de uma determinada ótica, que não é a sua no sentido subjetivo, mas é nossa porque diz respeito à comunidade de conhecimento da qual os sujeitos da enunciação fazem parte. Fazendo referência à aposta temática hegemônica do programa, o rock ${ }^{15}$, que muito diz sobre a comunidade afetiva na qual o texto se ancora, Massari costuma convocar, via texto verbal, a audiência: "rock clássico da me-

15 O rock é a denominação dada à variedade de estilos ou subgêneros desenvolvidos a partir do rock'n roll, definido como "gênero da música popular que surgiu quando as canções do rhythm'n blues negro começaram a ser difundidas pelas emissoras de rádio em busca de maior audiência, predominantemente branca, e quando os artistas brancos começaram a gravar canções do rhythm'n blues". (SHUKER, 1999, p. 247) Mais que uma prática musical, Grossberg (1997) descreve o rock como uma cultura, um conjunto de práticas discursivas que se materializam em diferentes textos partilhados. O rock inclui não apenas práticas e textos musicais, mas determinações econômicas, possibilidades tecnológicas, imagens, relações sociais, convenções estéticas, estilos de linguagem, aparência e dança, comprometimentos ideológicos e representações midiáticas (1997, p. 41). 
lhor qualidade" ${ }^{16}$, “fica aí a dica para você que gosta de rock'n roll”"17, “Muito rock'n roll no Jornal da MTV de hoje"18.

O consumo musical envolve formas de gostar e não gostar, hábitos de audição e outras práticas musicais que configuram um senso de comunidade entre os ouvintes. Assim, a música pop, em especial o rock, é entendida como um processo partilhado. Esse senso de grupo se funda em um processo de diferenciação em que a ideia do rock configura relações entre o que é considerado autêntico para uns e cooptado para outros. Como sustenta Frith (1998), é esse processo de diferenciação, entre o que é "original" e "falso", que marca as fronteiras identitárias de cada comunidade de conhecimento. As produções de sentido da música popular massiva, portanto, são marcadas pela tensão que envolve relações mercadológicas, afetivas e valorativas ancoradas na noção de autenticidade, assim identificada por Roy Shuker (1999, p. 28-29):

Durante a década de 1960, críticos norte-americanos - Landau, Marsh e Christgau - elaboraram uma visão do rock relacionando- o à autenticidade e aos movimentos de protestos daquele período ligados à contracultura. Associada a essa concepção de autenticidade, surge a revista Rolling Stone, em 1967. Essa autenticidade era sustentada por uma série de oposições: mainstream e independência, pop e rock, comercialismo e criatividade, arte e comércio. [...] A autenticidade exerce função ideológica ao ajudar na identificação de formas particulares de capital cultural musical.

A afirmação de autenticidade, fundamental para o entendimento de como se instaura o processo de construção dos relatos que dão conta dos acontecimentos do âmbito da música popular massiva, foi incorporada pelo Jornal da MTV veiculado no ano de 2002. As apostas genéricas do programa evidenciam conotações relacionadas à noção de integridade $\mathrm{e}$ originalidade de modo a conferir aos gêneros pautados lugares específicos em uma hierarquia musical. O ato de excluir certos gêneros musi-

16 Jornal apresentado em 08 de março de 2002.

17 Jornal apresentado em 24 de maio de 2002.

18 Jornal apresentado em 07 de junho de 2002. 
cais e legitimar outros reflete esse processo, que também remete à antiga discussão entre baixa e alta cultura. No texto audiovisual analisado, a autenticidade possui um grande valor simbólico como critério básico de avaliação.

Essa tensão entre autêntico e não autêntico responde por aquilo que é pautado pelo programa, o que significa que a mediação operada através do Jornal se vale de um explícito processo de diferenciação. Frith (1998), ao refletir sobre os argumentos da imprensa a respeito da música popular massiva, destaca duas posições familiares: 1. A música é julgada no contexto ou através da referência à critica da produção em massa (música boa seria original em oposição à música estandardizada); e 2. A música ruim é relacionada à ideia de cópia, o que reflete novamente um contraste com o que seria puro. O Jornal da MTV recorre a essas duas estratégias para explicitar os seus desacordos. Estes dizem respeito tanto a determinados gêneros musicais, quanto a produções que, mesmo fazendo parte de tipos musicais pautados (como o rock), não são consideradas autênticas pelo Jornal. Nessa perspectiva, os fatos que se revezam como notícia estariam, em sua maioria, no campo das marcações genéricas identificadas como originais. É nesse sentido de autenticidade que se funda o principal valor-notícia do programa.

Artistas supostamente identificados com as expressões musicais relacionadas ao termo pop, que, em sentido restrito, corresponde à adequação a demandas de mercado e é comumente associado à ideia de cooptação, raramente aparecem no programa. Quando mencionados, são relacionados à estandardização e ao comprometimento com os índices de vendagem. Na edição do dia 08 de março de 2002, gêneros relacionados a essa ideia de música de mercado, como o sertanejo, o axé music, o pagode e o funk carioca, foram veiculados, mas a partir de um enquadramento muito específico. A doença da dengue, que em 2002 registrou recordes de casos no Brasil, foi usada como gancho para a construção noticiosa sobre as "epidemias que atacam os nossos ouvidos". A reportagem abordou cenas e gêneros musicais que se tornaram "febres", jargão usado no âmbito musical para designar os estilos que apresentaram altos índices de vendagem e grande popularidade. Entre as manifestações 
musicais consideradas "epidêmicas", aparecem o grunge, o sertanejo, a música romântica, o axé, o pagode, o funk carioca e o new metal. O relato é construído a partir de um explícito processo de diferenciação, conforme off descrito abaixo:

- No início dos anos 90, Seattle nos apresentava o grunge. O grande transmissor dessa febre foi o Nirvana que provocou uma contaminação em larga escala. Na época, ninguém escapou dos quatro acordes de Smels Like Teen Spirit e nem daquelas camisas de flanela. Até hoje, tem gente apresentando sequelas. [Sobe-som do videoclipe da canção citada].

Outra epidemia que não vai dar para esquecer: a síndrome do sertanejo. Aquela modinha de viola que pôs o Brasil em polvorosa. Quem fosse picado pelos pequeninos mosquitos Zezé, Chitão e Xororó estaria condenado a sentimentos de traição, amores impossíveis e choromingos pelos cantos. [Sobe-som de videoclipe de Zezé de Camargo e Luciano].

Anos mais tarde, uma segunda geração desse vírus ganhou força. Para muita gente, basta ouvir os nomes: Sandy, Junior ou Wanessa Camargo para os sintomas aparecerem. Euforias, gritos histéricos e vontade incontrolável de dançar e comprar CDs. Ainda não há notícia de cura. [Sobe-som de videoclipe de Sandy e Junior] Já doenças como axé, pagode e funk carioca parecem ser rápidas como um resfriado. Do jeito que vem, vão. [Sobe-som do videoclipe da música Só as Cachorras].

Bom, uma coisa é certa, essa turma do Limp Bizkit, Linkin Park e Creed são uma espécie de recaída, independentemente da doença. $\mathrm{Na}$ verdade, o que eles mais atingem é a memória de quem escuta os seus CDs. Noves entre dez pacientes juram já ter escutado essa música antes. [Videoclipe da música Só as Cachorras]. ${ }^{19}$

O texto verbal do VT é coberto por imagens referentes aos artistas (trechos de videoclipes, capas de CD, fotografias) e cenas ilustrativas que remetem ao que está sendo dito em off (imagens de uma mulher tossindo,

19 Jornal exibido em 08 de março de 2002. 
gritos de fãs histéricas, pessoas atendidas por enfermeiras). O BG (background) e os sobe-sons são explorados durante todo o relato. O áudio aqui é um importante expediente informativo, pois faz referência ao que é narrado. Assim, por exemplo, a última frase do off 2 ("sentimentos de traição, amores impossíveis e choramingos pelos cantos") é seguida pelo áudio das vozes de Zezé de Camargo e Luciano em falsete pronunciando o verso: "é a sua indiferença que me mata".

O fundamental neste relato é entender o processo de diferenciação estabelecido, ainda que a partir de um mesmo quadro narrativo: "os modismos musicais". O primeiro off da reportagem coloca o movimento grunge, que inclui diversas bandas de rock agendadas pelo Jornal (Nirvana, Pearl Jam, Soundgarden etc.), dentro do frame "epidemia", mas de modo diferenciado dos outros estilos reportados. A primeira frase desse trecho revela que a cidade de Seattle "nos apresentou" o grunge. Aqui, o programa se coloca no mesmo local de fala do telespectador para dizer que "nós" fomos influenciados pelos "quatro acordes de Smels Like Teen Spirit". Essa cumplicidade não é observada nos demais trechos da reportagem. A narrativa agora distancia os estilos musicais reportados do local de fala dos sujeitos da enunciação: "aquela modinha", "quem fosse picado [...] estaria condenado", "para muita gente".

Nesse mesmo VT, o critério de autenticidade é usado para diferenciar música boa da música ruim, dentro de um dos gêneros agendados, o rock. Nesse trecho, é possível identificar o segundo argumento crítico destacado por Frith: a diferenciação estabelecida a partir da ideia de cópia, o que refletiria um contraste com o que seria original. As bandas de new metal aparecem como "epidemias" porque são tidas como cópias: "uma espécie de recaída”, "o que elas mais atingem é a memória de quem escuta os seus CDs", "pacientes juram já ter escutado essa música antes”. O relato é potencializado por um efeito de edição no final do VT, que retarda o sobe-som junto com a imagem, como se estivesse voltando a cena para trás, em referência ao tempo passado.

Esse processo valorativo também é ancorado em um hábito comparativo em que as bandas desconhecidas do grande público e noticiadas 
no Jornal são caracterizadas via diferenciação com outras já consagradas. A estratégia explicita que a mediação musical se vale de um exaustivo processo comparativo. O investimento em situar o novo artista a partir de uma referência, tanto em relação aos aspectos musicais, quanto performáticos, é um modo de organizar o próprio processo de audição. Em 24 de maio de 2002, na matéria sobre o grupo pernambucano Cabruêra, apresentado como "banda nova", o vocalista Arthur parte de referências a outros artistas para situar o seu possível ouvinte: "o nosso trabalho é semi-instrumental e experimental também, então viva Nana Vasconcelos, Uakti, Hermeto Pascoal".

A necessidade de diferenciação se ampara também em referências de gênero, que contemplam um conjunto de marcas reconhecidas socialmente nas quais se funda um determinado produto. Como estratégias de interação, os gêneros musicais funcionam para situar o ouvinte em relação a uma obra e ao modo de consumi-la. (JANOTTI JR., 2003) No Jornal da MTV, as marcas genéricas são a principal referência para o processo de mediação musical; o que significa que as notícias ou comentários sobre os produtos e concertos passam necessariamente por esta localização. Em 24 de maio de 2002, a entrevista feita pela VJ Penélope Nova com os integrantes da banda Agnostic Front, apresentados na cabeça do VT como "mestres do hardcore", foi marcada por questionamentos sobre o gênero musical do grupo: "hardcore para vocês não é só um estilo de música, mas um estilo de vida. Como veem o uso que o mercado faz disso?", "Hoje em dia o rap tem sido associado ao hardcore. Vocês não veem relação entre os estilos?”, "O que sabem da cena hardcore brasileira?".

O jogo valorativo proposto pelo programa também se vale de uma explícita adjetivação via texto verbal: "rock clássico da melhor qualidade" 20 , "bela melodia" 21, "banda muito bacana" 22 , "belíssimo disco do Hole" ${ }^{23}$,

20 Jornal apresentado em 08 de março de 2002.

21 Jornal apresentado em 08 de março de 2002.

22 Jornal apresentado em 24 de maio de 2002.

23 Jornal apresentado no dia 24 de maio de 2002. 
"título sensacional para um disco" 24 , "barulheira da boa" 25 , "o resultado é explosivo, inacreditável" 26 etc. De acordo com Simon Frith (1998, p. 68), no jornalismo musical, os adjetivos são utilizados para relacionar a música aos seus possíveis usos, "o rock fica melhor ainda quando acompanhado de uma bela dose de sensualidade" (08 de março de 2002), e para localizá-la a partir de marcas genéricas, "melódicos, sossegadas e baruThentinhos" (24 de maio de 2002).

\section{AS CONSTRUÇÕES NOTICIOSAS}

As coberturas do Jornal da MTV se concentram de forma acentuada no eixo São Paulo-Rio de Janeiro (território simbólico da produção fonográfica brasileira) e conferem expressivo espaço para reportagens da MTV de outros países (principalmente EUA e Reino Unido). No período de observação, os assuntos noticiosos circularam entre lançamentos de discos, clipes e publicações sobre música, bandas e artistas em estúdio, notas e coberturas de shows e festivais, novos grupos musicais, gravação de videoclipe, artistas em turnê, temas relacionados ao mercado fonográfico, como a pirataria, e repercussão de assuntos polêmicos, como a conversão religiosa de um artista de rock. As edições semanais também incluem matérias que dão voz à opinião dos artistas, produtores musicais ou demais VJs sobre determinado assunto, como "o que a banda The Hives acha da popularidade" 27 ou "quais videoclipes os VJs consideram como mais representativos" 28 .

Uma estratégia recorrente são as construções noticiosas baseadas em acontecimentos atuais da vida política, econômica ou cotidiana. A parada gay ocorrida em São Paulo, por exemplo, foi pautada pelo Jornal.

24 Jornal apresentado no dia 13 de setembro de 2002.

25 Jornal apresentado no dia 13 de setembro de 2002.

26 Jornal apresentado em 08 de novembro de 2002.

27 Jornal apresentado em 13 de setembro de 2002.

28 Jornal apresentado em 12 de abril de 2002. Ainda no âmbito da cultura pop, a cobertura temática do Jornal contempla assuntos da esfera cinematográfica. Neste caso, tais abordagens são construídas a partir dos aspectos musicais das produções, utilizados como critério de enquadramento: trilha sonora dos filmes, enredos sobre música, gêneros musicais preferidos dos atores. 
Mas para justificar a entrada do fato, ocorrido uma semana antes da veiculação do programa e já amplamente noticiado pela imprensa, foi preciso construir um enquadramento específico. Este é antecipado pela cabeça da matéria:

- No último domingo, cerca de 500 mil pessoas saíram em passeata pela cidade de São Paulo para declarar o orgulho de não ter preconceito contra os gays. O Jornal da MTV estava lá para lembrar alguns nomes da música que estavam nessa luta ${ }^{29}$.

O VT foi composto por sonoras de manifestantes sobre artistas e bandas que "lembraram a causa", por imagens do evento e trechos de videoclipes dos nomes citados.

A construção de enquadramento, que se relaciona ao ângulo de abordagem, ao quadro narrativo dado ao assunto pautado por um meio de comunicação (GUTMANN, 2006), é um modo encontrado pelo programa para legitimar o distanciamento temporal ou temático do acontecimento. No exemplo mencionado, o ângulo "artistas que defenderam a causa gay" foi usado para aproximar um acontecimento (a parada gay) do campo temático do Jornal. O investimento nesse expediente significante, a construção de quadros narrativos para emoldurar uma cobertura ou um assunto que se pretende destacar no programa, também funciona para autorizar uma espécie de distensão de uma das categorias que mais precisamente demarcam a atividade jornalística: a atualidade.

No Jornal da MTV, o critério de atualidade não se relaciona ao sentido de instantaneidade, como categoria de relação temporal que o jornalismo desencadeia para o tratamento dos eventos. Isso significa que um fato já ocorrido e já noticiado por outros veículos pode fazer parte da pauta semanal do programa. Esse aspecto é aqui explicado por dois fatores complementares: 1 . a periodicidade semanal do Jornal justificaria o não comprometimento com a ideia do aqui e agora da cobertura dos fatos; e 2. a relevância de fatos do universo musical pode se apoiar em critérios atemporais que dizem mais sobre o seu significado cultural do que pro-

29 Jornal apresentado em 07 de junho de 2002. 
priamente sua ocorrência no tempo presente. Este segundo fator, fundamental para o entendimento do pacto proposto sobre o papel do jornalismo, é caracterizado por uma espécie de distensão temporal: a atualidade não se aproxima da ideia de diminuição da distância temporal entre o fato e a mediação, mas da importância de determinado acontecimento para o universo musical. Assim, retomar a trajetória de uma banda que não existe mais ou colocá-la como parte do cenário do programa (através das inscrições no painel frontal) adquire um sentido de atualidade cultural apoiada na representatividade desses músicos para uma determinada cena ou na influência exercida sobre produções mais recentes.

Como programa de cunho jornalístico, o Jornal da MTV desenvolve estratégias próprias, articuladas às especificidades do assunto tratado, para colocar o telespectador no tempo presente, ainda que este sentido de atualidade não esteja ligado ao fato em si, mas a sua importância, valor significado para o universo musical. A estratégia se volta, mais uma vez, para a construção de enquadramentos que deem conta desse distanciamento temporal dos fatos e de sua transmissão.

O descolamento entre o tempo real do acontecimento e o tempo de veiculação pode ser observado com frequência nas coberturas de shows e festivais. Nesse caso, a inclusão da vivência cotidiana do espectador no mesmo tempo e espaço em que acontecem os fatos no universo musical é realizada pela construção de quadros narrativos atemporais responsáveis por aproximar o evento do público. O sentido do quando nesse tipo de cobertura perde força para a valorização do como, que irá direcionar o fato em si (o que), os personagens envolvidos na história (quem) e sua localização espacial (onde). Um exemplo dessa transgressão temporal pode ser visto na cobertura no Festival de rock Ceará Music, veiculada no dia 25 de outubro de 2002. Na matéria, apaga-se a localização do tempo, ao telespectador não é informado quando o evento aconteceu. A estratégia é dar conta do fato a partir de um determinado quadro narrativo: "por que os músicos gostam de festivais?". Essa moldura tem como objetivo presentificar o evento via identificação do telespectador com a história contada e não com o evento em si. A cabeça da matéria diz o seguinte: 
- Para começar, vamos a Fortaleza, no Ceará, que abrigou um festival lotado de grandes bandas do rock nacional e algumas independentes também. Foi lá que eu investiguei por que os músicos gostam tanto dos festivais. Nenhuma novidade, é claro, apenas teorias divertidas sobre o mundo do rock'n roll ${ }^{30}$.

O VT foi construído a partir de entrevistas com os músicos sobre a importância dos festivais e imagens dos shows e dos bastidores do evento.

A cobertura do Ceará Music ilustra um tipo específico de construção noticiosa, muito comum no programa, apoiada em traços atemporais e em critérios de relevância. É como se o Jornal fosse ao acontecimento a partir de uma história anterior criada para aproximar a construção noticiosa do cotidiano do telespectador/ouvinte. Nesse caso, a moldura construída para a matéria parece ser mais importante do que o fato propriamente dito.

Nessa mesma direção, também foram identificados relatos atemporais que potencializam uma perspectiva lúdica e divertida para o tema abordado através das construções de quadros narrativos: "bandas que entraram em casos diabólicos"31, "música versus religião"32, "peladões no palco" 33 . Desse modo, o programa procura oferecer ao telespectador informações e valorações a partir de um enfoque leve, descontraído, divertido, lúdico, de modo sintomático com o tema tratado.

Além do caráter lúdico que caracteriza os enquadramentos do programa, o texto verbal utilizado para a construção dos relatos se apoia em construções gramaticais marcadas pela informalidade e pela utilização de gírias ("sacar alguns discos", "a caretada de plantão", "mostrar para a rapaziada", "fiquem de olho nos caras"). Na mesma direção, os recursos da linguagem televisiva apostam numa plasticidade imagética própria do videoclipe, o que significa que não apenas o objeto mediado, mas também o modo de mediar se aproxima da noção de entretenimento.

\footnotetext{
30 Jornal apresentado em 25 de outubro de 2002.

31 Jornal apresentado em 08 de março de 2002.

32 Jornal apresentado em 08 de março de 2002.

33 Jornal apresentado em 12 de abril de 2002.
} 
Mas, ainda que o Jornal da MTV tenha no entretenimento um referencial para a relação proposta com o espectador, uma vez que se insere no universo da música popular massiva, não é este aspecto que responde pelo pacto sobre o papel do jornalismo. Aqui, o acordo proposto com o público sobre a função dessa especialização midiática é decisivamente marcado pelo ajuizamento de valor das bandas, cantores e suas manifestações. É esse pacto que assegura ao programa o lugar de formar a opinião dos ouvintes, orientando sobre "o que é bom" e "o que não é bom", contextualizando artistas, gêneros e cenas. Portanto, a maior demanda em relação ao jornalismo especializado em música praticado por esta primeira versão do Jornal da MTV se refere à formação de opinião.

Essa relação do telespectador com o programa também diz respeito à função de vigilância do jornalismo. O fato de o apresentador se comportar como Reverendo, como aquele que detém o conhecimento necessário para informar a audiência e discernir o que deve e o que não deve ser consumido, coloca-o como uma espécie de vigilante das produções da música popular. Nesse sentido, o programa credita ao jornalismo especializado em música um papel de difusor e, ao mesmo tempo, guardião das produções musicais. Esse aspecto também se relaciona à capacidade do Jornal de informar sobre o que é novo, sobre o que está surgindo no cenário musical. Assim, o fato de estar bem informado sobre música popular massiva legitima o pacto da formação proposto pelo programa ao seu interlocutor.

\section{REFERÊNCIAS}

BEDAQUE, Mauro. Mauro Bedaque: depoimento. Entrevistadora: Juliana Freire Gutmann. São Paulo:[s.n., janeiro 2005]. 1 fita cassete.

FABRI, Paolo. El giro semiótico. Barcelona: Gedisa, 1999.

FECHINE, Yvana. Estratégias de personalização dos apresentadores do SPTV: uma aproximação semiótica do problema. In: ENCONTRO ANUAL DA COMPOS, 9., 2000, Porto 
Alegre. [Anais eletrônicos...]. Porto Alegre: [s.n.], 2000. GT Mídia e Produção de sentido. 1 CD.

FRANCISCATO, Carlos Eduardo. A atualidade no jornalismo: bases para sua delimitação teórica. 2003. Tese (Doutorado em Comunicação) - Faculdade de Comunicação, Universidade Federal da Bahia, Salvador.

FRITH, Simon. Performing rites: on the value of popular music. Cambridge; Massachusset: Havard University, 1998.

GOMES, Itania Maria Mota. A noção de gênero televisivo como estratégia de interação: o diálogo entre os cultural studies e os estudos da linguagem. Revista Fronteiras, São Leopoldo, v. 4, n. 2, dez. 2002.

GOMES, Itania Maria Mota. Questões de método na análise do telejornalismo: premissas, conceitos, operadores de análise. E-Compos - Revista da Associação Nacional dos Programas de PósGraduação em Comunicação, v. 8, abr. 2007.

GOODWIN, Andrew. Dancing in the distraction factory: music television and popular culture. Minessota: University of Minessota Press, 1992.

GROSSBERG, Lawrence. Another boring day in paradise: rock and roll and the empowerment of everyday life. In:

Dancing in Spite of Myself: essays on popular culture. Durham/ London: Duke University, 1997. p. 29- 63.

GUERRA, Josenildo Luiz. O percurso interpretativo na produção da notícia. 2004. Tese (Doutorado em Comunicação) - Faculdade de Comunicação, Universidade Federal da Bahia. Salvador.

GUIMARÃES, Luciano. As cores na mídia: a organização da corinformação no jornalismo. São Paulo: Annablume, 2003.

GUTMANN, Juliana Freire. O contexto comunicativo como estratégia de mediação musical: considerações sobre o Jornal da 
MTV. E-Compós-Revista da Associação Nacional dos Programas de Pós-Graduação em Comunicação, v. 6, 2006.

Quadros narrativos pautados pela mídia: framing como segundo nível do agenda-setting? Contemporanea, Salvador, v. 4, n.1, jun. 2006.

JANOTTI JR., Jeder. Dos gêneros textuais, dos discursos e das canções: uma proposta de análise da música popular massiva a partir da noção de gênero midiático. In: ENCONTRO ANUAL DA COMPÓS, 14., 2005, Rio de Janeiro. Anais... Rio de Janeiro : Universidade Federal Fluminense, 2005.

. À procura da batida perfeita: a importância do gênero musical para a análise da música popular massiva. Eco-Pós, Rio de Janeiro, v. 6, n. 2, 2003.

SCHEUFELE, D. A. Framing as a theory of media effects. Journal of Communication, v. 49, n. 1, p. 101-120, 1999.

SHUKER, Roy. Vocabulário de música pop. Tradução de Carlos Szlak. São Paulo: Hedra, 1999. Título original: Key concepts in popular music.

VERON, Eliseo. Il est là, je lê vois, il me parle. Revue Communications, Paris, Seuil, n. 38, 1983. . La semiosis sociale. Barcelona: Gedisa, 1998. 



\section{Globo Rural: ao estilo da cultura do campo}

Jussara Maia

\section{INTRODUÇÃO}

Em meio ao contexto teórico-metodológico conformado pelos Estudos Culturais, esta pesquisa volta-se para a análise do modo de endereçamento do Globo Rural, de domingo ${ }^{1}$. A proposta, na dissertação, foi utilizar aspectos relativos ao gênero e ao modo de endereçamento para identificar as marcas que apontam para a definição do subgênero telejornal e do jornalismo temático. A amostra foi colhida no período de 23 de maio de 2004 a 22 de junho de 2004, reunindo cinco edições de domingo e 22 edições do Globo Rural semanal, exibido de segunda a sexta-feira.

Apresentado desde janeiro de 1980, o Globo Rural está entre os mais antigos programas jornalísticos temáticos da televisão brasileira, indicando a utilização de uma receita que está conseguindo conquistar e manter estável um bom nível de audiência. Significa que, além de construir e firmar no fluxo televisivo um espaço reservado ao jornalismo especializado, está conseguindo, com sucesso, atualizar o seu formato ${ }^{2}$, em meio às transformações por que passaram a televisão e a sociedade brasileira, nos últimos 25 anos. A partir de 2000, o Globo Rural passou a ser exibido também em edições diárias, às 6h15min, entre o Telecurso e o Jornal da Manhã (telejornal local). Mas, apesar do mesmo nome, os programas têm modos de endereçamento diferenciados.

1 Extraído da dissertação que analisa o Globo Rural em sua totalidade, as edições de domingo e as diárias, este texto limitou-se a apontar os principais aspectos relativos ao modo de endereçamento do programa dominical por considerá-lo o mais representativo da definição da identidade da produção. Como têm endereçamentos diversos, os programas mereceriam um aprofundamento de análise, cuja extensão não se aplica aos limites do presente artigo. Mais informações em Jussara Peixoto Maia (2005).

2 Sem uma precisão, o termo formato remete ao jargão usual das redações e diz, aqui, da arquitetura interna do programa. 
O nome do programa já esclarece quanto a sua inscrição na chamada comunicação rural, definida como

[...] conjunto de fluxos de informação, de diálogo e de influência recíproca, existente entre os componentes do setor rural e entre eles e os demais setores da nação afetados pelo funcionamento da agricultura ou interessados no melhoramento da vida rural. (BORDENAVE, 1983, p. 7)

As notícias e abordagens das reportagens se sucedem sem fugir do conteúdo esperado para um noticiário especializado, mantendo, claro, peculiaridades como marcas da identidade do programa. A terra que é a base da identificação, da raiz, da atividade rural, é também a principal referência do programa e elemento de conexão que vai possibilitar a criação de territórios simbólicos específicos, que ora se aproximam e ora se afastam das demarcações reais das cidades, estados e países. Depois da vinheta, já na escalada, na apresentação das principais notícias na abertura do programa, feita através de teasers, há um jogo de oposição entre a afirmação/declaração da localidade onde foi gerada a notícia e a negação/silenciamento desses locais onde foram feitas as gravações, atendendo a objetivos diversos. Na edição de 30 de maio de 2004, o programa utiliza uma estratégia que se repete ao destacar a localização das reportagens em cinco dos seis teasers da escalada:

- Loc 1: Na Paraíba, a gente mostra o gado Sindi, uma raça que veio do Paquistão para aumentar a rusticidade e melhorar a produção leiteira do rebanho do Nordeste.

- Loc 2: A suspeita de contaminação do grão de soja exportado para a China paralisa o comércio da safra gaúcha.

- Loc 3: Um jeito de combater o cupim sem aplicar o veneno, usando apenas um produto biológico.

- Loc 4: Você sabe como fazer o plantio do cupuaçu? No Amazonas a gente mostra como evitar o apodrecimento da semente.

- Loc 5: Em Mato Grosso do Sul, aumenta a diferença do preço do boi rastreado para o boi comum na hora da venda para o abate. 
- Loc 6: No Rio Grande do Sul, o assunto é rastreamento de maçã. Você vai conhecer o trabalho dos agricultores que não deixam a produção sair do campo sem o código de barra, com todas as informações sobre as frutas.

Além do texto em Loc 3 chamar a atenção para a tecnologia de combate ao cupim, em detrimento do local onde foi feita a gravação, a pergunta em Loc 4 se sobrepõe à demarcação do lugar ou se mistura a ela porque o cupuaçu é conhecido como fruto da Amazônia. Neste caso, vale também explicitar, de maneira discreta, a capacidade do programa de ir tão longe buscar a resposta (nos programas seguintes, o receptor com hábito de audiência vai perceber que o repórter/apresentador, Vico Iasi, estava na Amazônia para uma cobertura mais ampla sobre a atividade rural e o sistema de monitoramento da região). A reportagem destacada em Loc 1, que no teaser acentua a localização na Paraíba, é logo chamada pelo apresentador (Vico Iasi) na abertura do primeiro bloco. Antes de apresentar a primeira notícia do primeiro bloco, a de Loc 6 , o programa destaca mais uma vez a chamada da notícia de Loc 1 que só será apresentada no último bloco. O texto reconstrói a trajetória histórica do rebanho brasileiro, fazendo referência à chegada das várias raças e, dessa forma, torna o assunto não apenas relativo à Paraíba ou ao Nordeste, mas a todo o país:

Loc - Bom Dia, o extraordinário rebanho bovino brasileiro é o fruto de duas contribuições estrangeiras. Os bois da Europa e da Ásia e os capins originários da África. Aqui nós juntamos literalmente a fome com a vontade de comer. Os primeiros capins chegaram da África no enchimento dos colchões dos navios negreiros. Já as primeiras raças de bois vieram com os europeus, sendo que o grande salto aconteceu na passagem do século XIX para o XX com a chegada do gado indiano, as raças zebuínas: Nelore, Gir, Guzerá, principalmente. Hoje você vai conhecer uma raça zebuína do Paquistão que vive também no Afeganistão: o Sindi. É um gado de leite bom para o sertão do Nordeste ${ }^{3}$.

Com essa alternância, entre construção e desconstrução dos limites geográficos dos assuntos, o Globo Rural produz um novo mapa que per-

3 Programa exibido em 30 de maio de 2004. 
mite a aproximação com um "Brasil Rural”, acentuando a localização ou não. O mundo rural, aqui, está representado, de maneira determinante, pelo modo de vida das personagens e tudo que é colocado como parte do universo de seu interesse. Consideramos como modo de vida a referência trazida por Stuart Hall (1997, p. 3, tradução nossa), inspirada nos estudos de Raymond Williams.

Nos anos recentes e dentro de um contexto mais da 'ciência social', a palavra 'cultura' é usada para referir-se a tudo que é caracterizado como o 'modo de vida' das pessoas, comunidade, nação ou grupo social. Isto tem sido conhecido como a definição 'antropológica'. De maneira alternativa, a palavra pode ser usada para descrever o 'valor compartilhado' de um grupo ou sociedade - que é semelhante à definição antropológica, somente com uma ênfase mais sociológica ${ }^{4}$.

Longe da ostentação da capacidade técnica que já é uma marca da Rede Globo, o programa voltado para a temática rural, exibido aos domingos, fez escolhas que revelam a preferência por uma discrição que não está restrita apenas à tecnologia relativa ao aparato de equipamentos disponíveis à emissora. Essa é a tônica também do posicionamento adotado pelos mediadores, repórteres e, em especial, os apresentadores que "[...] personificam as características que são apropriadas para serem típicas da audiência-alvo" ${ }^{5}$, como destaca John Hartley (2001, p. 50).

\section{A VOZ DA EXPERIÊNCIA}

Não é casual que, além de serem os apresentadores mais frequentes no programa, Nelson Araújo, Helen Martins e Vico Iasi são também repórteres e, muitas vezes, apresentam suas próprias matérias. Mas, se por um

4 'In recent years, and in a more 'social science' context, the word 'culture' is used to refer to whatever is distinctive about the 'way of life' of a people, community, nation or social group. This has come to be known as the 'anthropological' definition. Alternatively, the word can be used to describe the 'shared values' of a group of societh - which is like the anthropological definition, only with a more sociological emphasis." (HALL, 1997, p. 2)

5 "[...] 'figures who personify characteristics which are taken to be typical of the 'targ'et'audience'[...]” (transcrição literal, em inglês, do trecho da definição do mediador). 
lado, há uma proximidade ao ser afirmada a credibilidade tanto do apresentador quanto do repórter para "contar a história”, por outro, há um afastamento no posicionamento diferenciado do apresentador que ocupa um patamar de autoridade mais elevada para ser, acentuadamente, pedagógico ao se dirigir à audiência. Ao lado dos apresentadores/repórteres citados, é possível identificar uma posição diferenciada de outros três repórteres que cumprem uma função estratégica no endereçamento do programa. Ivaci Matias, Ana Dalla Pria e José Hamilton Ribeiro são, assim como os apresentadores, reconhecidos por uma autoridade diferenciada em relação aos outros repórteres, mesmo não acumulando a função de apresentadores. Juntos, eles formam um grupo de repórteres especiais, responsáveis pela principal marca do programa, inclusive, na diferenciação em relação às edições diárias, durante a semana. São eles que fazem, quase invariavelmente, as reportagens especiais, mais longas, com efeitos especiais e sonorização, destacadas nos teasers, na abertura do primeiro bloco e na chamada para o programa de domingo, feita na edição da sexta-feira. Quase sempre, quando aparecem no vídeo (em abertura, passagem ou encerramento), não utilizam o microfone direcional, predominante nos telejornais, que, por serem visíveis, destacam o papel mediador da tecnologia empregada na televisão. Mais frequentemente, utilizam o microfone boom (usual nas gravações para o cinema) que fica preso a uma haste móvel acima da cabeça das pessoas que participam da entrevista, sem ficar exposto. No enquadramento, é oferecida para o telespectador uma terceira posição entre o repórter e o entrevistado na "conversa" encenada, a de um participante pressuposto.

Os seis repórteres têm uma identidade profissional estritamente vinculada ao Globo Rural e reconhecida pelos telespectadores, na perspectiva do saber compartilhado pelo hábito de audiência na televisão brasileira. Nenhum desses profissionais aparece em outros programas da Rede Globo, exceto quando são vinculados à sua participação na equipe do Globo Rural. Bem diferente do que ocorre com apresentadores e repórteres da edição diária do programa. As marcas do diálogo e da participação são exploradas intensamente nas reportagens feitas por eles. Todos possuem, com mais ou menos intensidade, uma locução marcadamente pausada 
para acentuar o tom dialógico da reportagem e do programa. Com trajes ajustados ao ambiente em que gravam as imagens e entrevistas, eles se vestem de modo despojado, simples, com calças jeans e camisas em tons claros com as mangas dobradas, bem distintos dos paletós e blazers usados pelos repórteres dos telejornais. Muitas vezes, recorrem ao uso de botas para se adequarem ao local, quando estão em mata fechada ou regiões alagadas.

O posicionamento assumido pelos apresentadores, mesmo no caso de Nelson Araújo, não permite identificá-los com o modelo do "apresentador-ventríloco" descrito por Eliseo Véron (1983), em que o apresentador é considerado como um mero ponto de passagem do discurso informativo, um suporte neutro que não utiliza qualquer operador de modalização. Os apresentadores do Globo Rural exploram, ainda que de modo restrito, o espaço físico do estúdio com a exibição de cartas, folhas, sementes e produtos do campo, ao lado da movimentação corporal provocada pelo manuseio desses itens. Utilizam, também, uma expressão fisionômica que oscila entre o distanciamento e a proximidade e o emprego frequente de um texto que simula um diálogo, sempre com um sentido de interpretação. É o que autor considera um sistema gestual complexo do corpo midiatizado de um "meta-enunciador", que é construído a partir do encontro dos olhares entre público e apresentador, como uma dimensão do contato, numa operação denominada de eixo $0-0^{6}$. Mas aqui, a intensidade da expressão desse sistema, o olhar e o corpo significante que Véron (1983) denomina de rede metonímica, é ajustada a um nível de equilíbrio e suavidade que conferem ao Globo Rural uma das marcas do seu modo de endereçamento. A notícia é interpretada pela entonação da voz e pela expressão fisionômica dos apresentadores que, ao tempo em que informam, também orientam, construindo um modelo que o grupo de pesquisa Análise de Telejornalismo define como do "apresentador intérprete". Semelhante ao ator, o apresentador produz um

6 “[...] el noticiero televisivo ha elegido constituirse alrededor de esta operación fundamental que, en tanto índice del régimen de real que le es proprio: los ojos en los ojos, se convierte en una de las marcas del género. Denominamos a esta operación el eje 0-0”. (VÉRON, 1983, grifo do autor). 
sentido ao interpretar o que diz o texto verbal através da modulação do tom da voz, da movimentação da musculatura do rosto e da expressão corporal. O "apresentador intérprete" não chega a explorar tanto o espaço da apresentação do programa jornalístico, como o modelo do "meta-enunciador" de Véron (1983) define, mas utiliza, também, um sistema gestual que constrói, ao mesmo tempo, uma modalização do que é dito e uma esfera de contato com o público. Uma das características do "meta-enunciador”, segundo Véron (1983), é a de dominar os especialistas, introduzindo todos os acontecimentos importantes, fazendo a conexão entre os blocos e assuntos do telejornal e encerrando a apresentação das informações com uma reflexão que, veremos à frente, não é, no caso do programa analisado, exatamente uma reflexão.

No objeto em análise, os especialistas são referências permanentes, reiterando o tom de orientação do programa. Eles estão presentes com um destaque especial em reportagens na seção de cartas que, em algumas edições, pode ocupar dois dos quatro blocos. Na maioria das vezes, cabe ao repórter ir até os profissionais especializados para formular as questões levantadas pela audiência através de carta. Mas, além de normalmente um dos apresentadores protagonizar também uma reportagem que responde à dúvida de um telespectador, ao exibir as cartas, quase sempre manuscritas, nas mãos do apresentador no estúdio, o programa mostra que ele, o Globo Rural, é o endereçado da correspondência. É com esta autoridade, daquele que personifica o perfil da audiência visada, que o apresentador comprova que é capaz de mobilizar as vozes especializadas, transferindo a tarefa de buscar respostas ao repórter. Na maioria das vezes, a carta é levada, também, nas mãos pelo repórter, enquanto este realiza a entrevista fazendo, quase sempre, uma abertura no início da reportagem. A utilização desse padrão revela a sustentação do eixo 0-0 iniciado pelo apresentador que convida o público a acompanhar e seguir o repórter também ao nível da cobertura do fato, mantendo uma das características da comunicação rural fortemente marcada pela tradição da oralidade.

Os meios visuais e audiovisuais são particularmente indicados para a comunicação rural, por diversas razões. Uma delas é que a cultura 
rural é eminentemente oral e outra o fato de que as imagens atraem e mantêm a atenção de maneira poderosa. (BORDENAVE, 1983, p. 67)

\section{CONVITE AO DIÁLOGO}

As pessoas que vivem neste mundo rural ou que reconhecem vínculos com esta esfera de abordagem da temática são convidadas a um diálogo que o programa pressupõe e configura com a sua audiência. O enquadramento nas entrevistas reserva espaço para a presença de uma terceira pessoa que, desse modo, é convocada para conversar e desvendar o universo das atividades e do modo de vida do campo, ao lado do repórter, do especialista e/ou produtor que não têm um microfone direcional à frente. O tratamento de "doutor" na entrevista com especialistas, independente da sua formação na área médica, traduz o respeito à figura do profissional com formação de nível superior, típico da cultura do campo. Assim, o Globo Rural destina para si uma posição próxima daquela ocupada pelo homem do campo, ratificando a credibilidade que o especialista tem no meio rural. De modo implícito, assegura a credibilidade de suas informações pelo acesso aos “doutores”. São combinadas personagens e histórias reais numa cena construída para traduzir um mundo que ganha significado pela interpretação implícita de uma natureza pujante, sedutora e parte do sucesso com a vitória sobre os desafios, embalado nos sons tradicionais e elementos de apelo cultural.

O telespectador é representado como aquele que partilha interesses pelas referências rurais expressas em procedimentos técnicos e/ou aspectos das múltiplas raízes culturais brasileiras inscritas no modo de conduzir as matérias jornalísticas. Com este posicionamento, o Globo Rural de domingo assume, através da estratégia comunicativa do diálogo, o papel de conselheiro e pressupõe um público que não é composto apenas pelo homem do campo, mas, também, aqueles que vivem em centros urbanos e têm em comum o traço cultural que aqui assume o papel de um idioma. A vertente cultural que modula a formatação serve de senha no endereçamento ao produtor que se sente incluído, ao reconhecer-se pela familiaridade, e ao citadino, que é convidado e seduzido a desvelar o, ainda pouco conhecido por ele, universo rural. 


\section{AUTORIDADE DE CONSELHEIRO}

Os apresentadores são constantemente reafirmados, através de diversos expedientes, como conhecedores daquilo sobre o que estão falando. É esta, na realidade, a finalidade da nota pé, que não tem no programa a função que normalmente lhe é atribuída nos telejornais. A nota pé corresponderia à reflexão a que se refere Véron (1983), citada anteriormente, que, aqui, ocupa a posição traduzida pela metáfora do conselheiro e tem uma informação colhida junto aos especialistas, não divulgada na reportagem, para que tenha sempre a palavra, a recomendação final. É o conselheiro que incorpora, de forma comedida e circunspecta, a autoridade, o conhecimento e a familiaridade que, combinados, modulam todos os apresentadores, mas, especialmente, o posicionamento de Nelson Araújo diante do telespectador.

A utilização do pé é um padrão do Globo Rural, que o coloca após, absolutamente, todas as reportagens. Só para exemplificar vamos citar a reportagem mais longa da amostra, que foi a exibida nos terceiro e quarto blocos da edição de 13 de junho de 2004, sobre o Instituto Butantã. Após 21 minutos de reportagem, o apresentador Nelson Araújo complementou:

Loc - O pessoal do Instituto Butantã pede para que não mate as cobras, que podem ser muito mais úteis para a pesquisa do que mortas. E quem quiser mais informações é só escrever para lá. O endereço é $[\ldots]^{7}$.

Na segunda reportagem mais longa da amostra, que foi exibida no dia 06 de junho 2004, sobre o papel das abelhas na produção da própolis verde, no terceiro e no quarto blocos, com um total de 19 minutos, o exemplo é ainda mais rico e muito significativo. Incomum no formato do programa, o repórter Ivaci Matias foi para o estúdio, sentar-se ao lado dos apresentadores, mas não apenas para apresentar a matéria. A presença do repórter foi uma estratégia que visou a dois objetivos. O repórter sentou-se à direita de Nelson Araújo, que dividia a apresentação com Priscilla Brandão, que normalmente apresenta as edições diárias, para complementar as explicações sobre o assunto e atuar como elemento de

7 Programa exibido em 13 de junho de 2004. 
conexão entre os trechos da cobertura feita por ele e aqueles realizados por um profissional estranho ao programa. Antes de iniciar a primeira parte da reportagem os dois apresentadores, sob a condução de Nelson Araújo, fizeram perguntas sobre a própolis verde que foi colocada sobre a bancada, ao lado da própolis comum. Ivaci Matias começou, inicialmente, a responder e solicitou que fossem exibidas as imagens "enquanto nós continuamos o papo". Em seguida, foi apresentada a primeira parte da reportagem e, no quarto bloco, o último trecho com o material feito por um repórter japonês que tem seu nome revelado no texto sobre a gravação no Japão, para depois retornar ao estúdio, onde mais uma vez o repórter foi questionado pelos apresentadores da mesma maneira anterior.

A reportagem foi feita em várias localidades de Minas Gerais, São Paulo e, excepcionalmente, no Japão, onde as imagens e entrevistas foram realizadas por um repórter daquele país. Foram empregados dois modos de orientação para o telespectador perceber a mudança de localização da gravação. A matéria mostra o modo mais usual do programa, e bastante pedagógico, de interligação entre gravações feitas em locais diversos, com a exibição de imagens do carro, uma pick-up com a logomarca do Globo Rural, chegando à nova localidade que o texto indica. Foi utilizado, também, o mapa do mundo, com o globo terrestre fazendo um giro de 180 graus numa animação gráfica para explicar que o Japão fica do outro lado do mundo, em relação ao Brasil. Assim constituída, esta formatação reitera a valorização do trabalho do repórter, mas acentua ainda mais a posição do apresentador que fez, antes e depois, no estúdio, as perguntas que não estavam na reportagem. Por que foi necessário levar Ivaci Matias para o estúdio? Por que o repórter não poderia fazer essa condução do local onde foi feita a cobertura?

No estúdio do Globo Rural, Ivaci Matias utilizou a sua posição de repórter somada à do apresentador conselheiro que no Globo Rural é legitimado e credenciado para cumprir uma função de orientação cuidadosa, de familiaridade e, ao mesmo tempo, de autoridade, para explicar a presença do repórter japonês, colocar e perguntar mais detalhadamente acerca da complexidade dos elementos científicos da notícia. Fora da reportagem, a presença do repórter foi mais marcada por estar ali no pa- 
tamar dos apresentadores e não no espaço da cobertura jornalística. Aos apresentadores coube fazer as questões que não estavam na reportagem e representar os interesses do país, portanto, de todos os brasileiros, agricultores ou não, ao perguntar sobre como adquirir a própolis verde. E ao saber que todo o produto é exportado e patenteado no Japão, traduzir o desejo comum de que seja possível trazer de volta as patentes para o Brasil.

\section{MODO DE FALAR COMO ESTRATÉGIA DE FAMILIARIDADE}

Assim como o repórter José Hamilton Ribeiro, Nelson Araújo constrói no programa uma posição diferenciada mesmo na equipe que, como foi destacado antes, confere as principais marcas do Globo Rural dominical. Há posições, no entanto, distintas no desempenho das funções de repórter e de apresentador, que possuem suaves diferenças e se complementam. Como repórter, Nelson Araújo, também acentua as marcas do diálogo e da linguagem oral com características marcadamente rurais. Como resultado desta escolha particular, desenvolveu o chamado "cordel eletrônico", uma modalidade de texto telejornalístico que traduz, com clareza, suas intenções voltadas para a valorização de aspectos culturais, do modo de falar e de viver dos lugares onde são feitas as reportagens. Semelhante ao texto de cordel, tradicional no interior nordestino, a matéria é apresentada através de rimas, com a inclusão de regionalismos e uma narração mais ritmada que fica mais compassada e é acompanhada de sonorização. Mais à frente, sintetizando o papel assumido por Araújo, será apresentado um trecho de uma reportagem no formato de trovas, no "cordel eletrônico", que ganha uma conotação bastante especial e diferenciada.

Do mesmo modo que José Hamilton Ribeiro, Nelson Araújo atesta a familiaridade com a vida do campo, também com o uso da montaria típica do local que está sendo foco da reportagem, seja cavalo, burro ou jumento. Apesar dos óculos, ele não possui uma aparência de intelectual distante do mundo natural do campo e, ao contrário, inclui, quase sempre, o uso de um colete sobre a camisa de manga quando aparece nas gravações. Mesmo sendo de tecido e não de couro, como aquele que tra- 
dicionalmente é utilizado pelos trabalhadores que lidam com os animais, o colete compõe um figurino que auxilia na configuração da posição de naturalidade com o mundo do homem do campo, suas tarefas, modo de vestir, de falar, preocupações, sonhos e valores.

Nelson Araújo acentua a marca de diálogo participativo, de naturalidade, que é reforçada pelo ritmo da locução. Como um ator, ele parece encenar uma conversa com um telespectador que procura presentificar através de suas falas. Em resposta a uma carta, na edição de 23 de maio de 2004, como repórter, ele vai a uma plantação de milho responder à curiosidade do remetente. Na cabeça, lê o seguinte texto:

Loc - O Valdir Rassi, de Moreira Sales, Paraná, está coçando a cabeça de tanta curiosidade. Ele quer saber: pé de milho dá flor? Onde fica a flor do milho? E pergunta, também, sobre o cabelo do milho ${ }^{8}$.

Aqui, Nelson Araújo, assume o papel de representante da audiência, valoriza e reproduz suas questões, preocupações, dúvidas e anseios e até seu modo de falar ("está coçando a cabeça”), mas mantém um distanciamento, em comparação com a posição que ocupa na função de repórter. Durante a gravação, o apresentador, com autoridade de conselheiro, abdica desse patamar mais elevado e reconfigura sua posição para dialogar, no mesmo nível, com o seu telespectador que pode ser um homem do campo que já tem conhecimentos básicos, mas constrói o espaço, também para o público, que sequer conhece o cabelo do milho. O texto abaixo é narrado, enquanto o repórter anda em um milharal, aponta, com o milho na mão, para os cabelinhos da espiga (enquadrada em detalhe) e vai até o especialista para iniciar o diálogo, referindo-se diretamente ao telespectador. O enquadramento mantém o padrão do "plano médio", que mostra as pessoas até a altura das pernas ou de corpo inteiro, com o recorte do repórter posicionado na diagonal, deixando o espaço para um terceiro interlocutor: a audiência.

Loc - O cabelo do milho é esta parte aqui, esses fiozinhos que aparecem na ponta da boneca. Waldir diz que no Paraná costumam

8 Programa exibido em 23 de maio de 2004. 
dizer que cada grão tem seu próprio cabelo, quer saber se isso é verdade e pergunta também se o cabelo do milho é a flor do milho. Quem vai esclarecer essas dúvidas é o Manoel Xavier dos Santos, agrônomo do Departamento de Genética e Melhoramento da Embrapa de Sete Lagoas. Xavier é verdade isso? Cada grão tem seu próprio cabelo? ${ }^{9}$

Mais do que qualquer outro mediador, Nelson Araújo acentua na apresentação e nas reportag'ens o entusiasmo e o encantamento com o mundo rural, mantendo uma expressão sorridente, de contentamento, que só é quebrada com a apresentação de notícias negativas, pouco comuns no programa. Com uma posição diferenciada, cabe a ele, quando divide a apresentação com outro mediador, apresentar as principais matérias do dia, destacar aspectos da proximidade do programa com a esfera rural (a exemplo do plantio de uma semente de pau-brasil no jardim da área que cerca o estúdio da Rede Globo, onde são feitas as gravações, para comemorar um marco de exibição de edições), assumindo com mais intensidade o tom de conselheiro, utilizado pelo programa. Foi com esta posição destacada que Araújo apresentou a reportagem, em 30 de março de 2003, sobre o casamento da filha mais nova de um produtor rural que o convidou para ser o padrinho. Na realidade, foi uma série de reportagens (12 de maio de 2002, 04 de junho de 2002, 06 de outubro de2002 e 20 de março de 2003) produzidas por ele sobre a vida de "seu” Zé Izá, após a primeira, apresentada em 1997. O motivo do convite foi justificado pelo fato de que as filhas do agricultor casaram-se após a exibição de uma reportagem sobre a atividade agrícola desenvolvida pela família. Como é marca do Globo Rural incluir informações detalhadas sobre a família, Nelson Araújo havia informado que todas as filhas eram trabalhadoras e prendadas, mas ainda eram solteiras e esperavam fazer um bom casamento. Durante a matéria, apresentada em duas partes, além de aparecer como participante da cerimônia e da comemoração, foram mostradas imagens antigas que, enquanto reafirmava a fidelidade do programa ao compromisso com a esfera rural e cada produtor, individualmente,

9 Programa exibido em 23 de maio de 2004. 
fortalecia a identidade do apresentador/repórter com o programa e sua principal inspiração. Com este formato de notícia e o próprio conteúdo familiar da notícia sobre o casamento, são reafirmadas interfaces dos aspectos pessoal, subjetivo e familiar que são construídos em todas as outras características na abordagem dos temas rurais. É com esta marca de familiaridade que Nelson Araújo, também, experimenta todas as iguarias que são produzidas nas reportagens, algumas vezes, sem esperar até o final do preparo e, com desenvoltura, ele prova diretamente da panela, expressando sua satisfação, enquanto saboreia. No âmbito da experiência, atesta uma convivência natural com o universo rural.

Os mediadores cumprem, assim, um papel fundamental para conferir o modo de endereçamento do Globo Rural, reproduzindo com maior ou menor intensidade uma posição de proximidade, familiaridade, naturalidade e encantamento com os valores, tradições, procedimentos, processos, traços culturais e modo de vida do campo. Vale destacar, no entanto, as posições de Nelson Araújo e José Hamilton Ribeiro que circunscrevem uma configuração bastante específica, cada um, conferindo as suas participações, como repórter e/ou apresentador, marcas pessoais, mas profundamente sintonizadas com a posição que o programa quer construir para a sua audiência.

\section{NOTÍCIA HUMANIZADA}

Apesar da valorização da informação pela sua utilidade para a lucratividade dos negócios do homem do campo, o programa não possui uma abordagem marcadamente mercadológica graças à chamada humanização do relato. É o critério de noticiabilidade denominado de Interesse Humano $^{10}$, que aborda os acontecimentos a partir de uma ótica particular, do modo como uma ou várias personagens enfrentam uma determinada situação, largamente utilizado no Globo Rural, na estrutura das matérias desenvolvidas a partir da história de um indivíduo ligado ao campo. Na seção de cartas, o "interesse humano" é substituído pelo "interesse

10 "A frialdade das estatísticas, a descrição de uma obra pública que será inaugurada, bem como o discurso de um governador ou um debate na ONU, devem ser entremeados com notícias que falem do próprio homem, que participa desses acontecimentos [...]." (ERBOLATO, 2002, p. 62) 
pessoal", também incluído nos critérios de noticiabilidade enumerados por Erbolato (2002, p. 62), que considera que “[...] os jornais não podem deixar de divulgar notícias que, de certo modo, afetam pessoalmente cada um dos que os lêem".

Um exemplo da humanização do relato é a reportagem, exibida no dia 23 de maio de 2004, com o caso de dois produtores de leite para contar as dificuldades enfrentadas pelo setor que busca mais rendimento através da formação de cooperativas, mas tem problemas com a falta de higiene e de cuidados com a conservação. O fato noticioso que está por trás da notícia é a nova exigência que faria parte do regulamento técnico do Ministério da Agricultura, no ano seguinte, tornando obrigatório outro teste no leite, o da contagem total de bactérias. Mas esta informação só é dada no trecho final da matéria que começa com o exemplo negativo do produtor Luís Antônio em comparação com a experiência mais profissional e cuidadosa do criador Osvaldo de Paula para, em seguida, destacar as orientações de técnicos especialistas sobre os cuidados necessários.

Loc -Todo mundo sabe o quanto o leite é importante na alimentação humana, principalmente das crianças, por isso, a higiene na ordenha e a conservação do leite são cuidados fundamentais. É o que você vai ver na reportagem do Ivaci Matias ${ }^{11}$.

Vale destacar aqui que a utilização da humanização do relato precedida de um texto como este acima, na cabeça, permite que, ao mesmo tempo, o programa desperte o interesse do homem do campo, ligado à produção ou ao consumo do leite, e o homem da cidade que tem a oportunidade de conhecer a trajetória percorrida pelo produto. Há no Globo Rural a valorização da autoridade jornalística, representada pelos que estão em posição de comando, por isso, logo após os teasers, durante a exibição da abertura do programa com belas imagens de paisagens, plantações, fauna e flora diversas, antes da nota de abertura, são apresentados os créditos do editor-chefe, chefe de redação, chefe de reportagem, editores, produtores e consultores (um agrônomo e um veterinário). É bem dife-

11 Programa exibido em 23 de maio de 2004. 
rente dos telejornais e mesmo de outros produtos também especializados em que os nomes dos produtores são hierarquicamente dispostos no final da apresentação, iniciando da equipe de produção até a chefia do departamento.

No Globo Rural a esfera do campo é identificada e contextualizada a partir de um olhar que, apesar de romântico, inclui, também, as dificuldades, mas sempre contrapostas com as soluções. Desse modo, nenhuma das reportagens é encerrada de modo negativo, desanimador, sem esperanças de superação dos desafios, sem apontar os caminhos ou exemplos positivos. Não há uma abordagem que traduza um impasse, uma situação de interpretação dúbia, sem o desenlace favorável ou otimista, ainda que tenha deixado para trás as personagens que encenam o lado sombrio da realidade, minimizadas pela acentuada valorização dos referenciais mais produtivos. É assim que o "mundo do Globo Rural” extrai de seu universo os inúmeros e sangrentos conflitos pela terra, exibidos nos telejornais, e a realidade de um país ainda marcado pela miséria e pela presença dos latifúndios e dos coronéis. No lugar dessas feridas sociais, os mesmos protagonistas destas cenas reais do interior brasileiro são reconfigurados para compor um mundo encantado, repleto dos mais diversos e ricos recursos naturais e traços culturais.

Os media definem para a maioria da população os acontecimentos significativos que estão a ter lugar, mas também oferecem interpretações poderosas acerca da forma de compreender estes acontecimentos. Implícitas nessas interpretações estão as orientações relativas aos acontecimentos e pessoas ou grupos nelas envolvidos. (HALL et al, 1993, p. 228)

A união dos elementos, antes enumerados, firma, de modo tácito, o compromisso jornalístico na perspectiva da conversação social e do jornalismo utilitário ou de serviço, mas o Globo Rural constrói um olhar que amplia a noção do que é este 'mundo do campo'. O modelo pedagógico, detalhista, explicativo, é empregado, mas sem a superioridade daquele que pretende ensinar a quem nada sabe. Ao contrário, é um caráter de orientação, daquele que se propõe a dar instruções sobre um 
procedimento, técnica, cultura ou agronegócio. Enquanto nas matérias de cunho, predominantemente, cultural o enfoque jornalístico é na missão assumida pelo programa de desvelar o universo rural com sua variedade e riqueza de cenários, regionalismos, valores, tradição e diversidade cultural, de modo a estimular a formação da opinião pública para a conversação social.

\section{O ESTILO DO GLOBO RURAL DE DOMINGO}

O caminho escolhido pelo programa para explorar o seu eixo temático traduz uma expectativa quanto ao seu público, ao voltar-se para a valorização da terra como referencial não apenas dos procedimentos técnicos locais. Mas, mais intensamente, o Globo Rural constrói com seu telespectador uma afinidade com os aspectos relativos aos caracteres culturais de cada espaço geográfico, enaltecendo implicitamente, o papel transformador do homem no campo. Posicionado como uma espécie de modelo, o receptor endereçado pelo programa não é o que, necessariamente, vive no campo, mas aquele que detém competências culturais para reconhecer a importância dos recursos naturais, da preservação das tradições da cultura local e, também, no caso dos telespectadores com experiência rural, para aqueles que buscam crescimento pessoal e dos negócios. Uma audiência com referenciais urbanos e rurais, com múltiplos interesses, pode ser capturada através dos temas e formas de abordagem que convidam, continuamente, à conversa sobre estas afinidades.

O posicionamento discreto dos apresentadores num cenário simples e um apagamento dos recursos tecnológicos, acessíveis à Rede Globo, mostram a opção pela identificação do Globo Rural com os valores e um modo de vida baseados na relação humana, na conversa face a face, sem pressa, que tem sua força na palavra. A marca acentuada do diálogo reivindica traços próprios da cultura popular, marcada pela oralidade, pelo tom despojado dos contatos absolutamente informais, interpretados como autênticos e verdadeiros. O programa utiliza a metáfora do diálogo para tentar ocultar o seu caráter midiatizado, modelando-se para um público que não é seduzido por apelos visuais de efeitos especiais, cores e brilhos, explorados num mundo virtual e fantástico, seduzido 
pela transmissão em tempo real. É um telespectador pouco atraído pela entonação espetacular e bombástica, largamente utilizada na locução rápida das notícias de maior relevância nos noticiários do horário nobre, e resistente aos excessos de maquiagem e enfeites nas mulheres. No lugar dessas opções, são bem-vindos a voz compassiva, segura e no ritmo de uma boa conversa, o traje cuidado, mas sem sofisticação ou exagero de cores fortes e formalidades. Nessa perspectiva o programa se endereça à cultura própria do homem do campo de qualquer parte do país e, dessa forma, modela suas escolhas nos mínimos detalhes.

Mas o mundo reconfigurado pelas escolhas de abordagem dos assuntos revela nuances que favorecem a identificação do homem do campo mais restrito às regiões do país onde o desenvolvimento tecnológico, que foi apagado lá do aspecto visual do programa, foi empregado para industrializar os sistemas de plantio, colheita e comercialização. É para este perfil de audiência que o programa se destina de modo especial, ao abordar as modernas tecnologias de manejo e de cultivo, atenta às inovações que colaborem com a produtividade do campo. É um olhar que se volta para a perspectiva de grandes produtores que há duas décadas se localizavam mais especificamente no Sudeste, Sul e parte do Centro-Oeste e, através das exportações e a partir das exigências do mercado internacional, inscreveram as inovações tecnológicas na sobrevivência de seu negócio. Nos últimos anos, com a crescente profissionalização do campo e a ampliação das fronteiras agrícolas, a atuação dos agricultores vem se estendendo, gradativamente, para o resto do país. Por isso, o referencial de homem do campo endereçado pelo Globo Rural não é, preferencialmente, aquele típico do interior do Norte e Nordeste, sozinho, adepto da agricultura familiar, distante da estrutura organizada das cooperativas, desprovido de escolaridade e cheio de dificuldades para desenvolver sua produção. Este, quando aparece, é para exemplificar os desacertos em contraposição com os casos de outros agricultores, mais bem-sucedidos, que souberam buscar o apoio dos especialistas em institutos de pesquisa, universidades e órgãos públicos.

O homem do campo endereçado é aquele que se envolve com uma atuação mais profissional e participativa, que está aberto às ferramentas 
tecnológicas modernas e à gestão coletiva da produção em cooperativas e associações, de olho nas oportunidades oferecidas pelo mercado, dentro e fora do país. Por isso, o programa não limita a cobertura jornalística à atividade realizada só na terra e nos centros de armazenagem, mas acompanha todas as etapas até a industrialização, preços e, em alguns casos, a operação das empresas envolvidas na comercialização. Mas, ao contrário do que parece numa avaliação precipitada, o Globo Rural não se endereça ao homem do campo apenas geograficamente situado na esfera rural. Utilizando o viés das expressões da cultura popular, o programa utiliza estratégias que visam a atrair a atenção de um público formado não apenas pelas pessoas que nasceram ou vivem no campo. Também aquelas que possuem referências simbólicas, através de familiares ou amigos, ou que se reconhecem nas semelhanças com os múltiplos elementos culturais, originários dos quatro cantos do Brasil, fortemente explorados, se sentem incluídas no cenário construído. Ou ainda, aqueles telespectadores que desconhecem, mas possuem um interesse pela identidade cultural das regiões, cada vez mais presente no momento em que as fronteiras se dissolvem no processo de globalização. Com as abordagens marcadas pelos valores culturais, da história de cada lugar e as imagens que traduzem a amplitude de ricas e múltiplas paisagens, o Globo Rural oferece um largo espaço para quem busca informações, movido por interesse turístico, na perspectiva do turismo cultural. Conhecer o modo de vida de cada povo, expresso em sua culinária, suas histórias, trajes, danças, lendas, músicas, rituais, linguagem, construções arquitetônicas, é considerado, hoje, uma grande fonte de atração.

A ausência proposital de uma diferenciação, um destaque especial, entre as reportagens produzidas em zonas rurais daquelas gravadas nas zonas urbanas de cidades do interior do país, dissolve os limites geográficos e interpela o telespectador que valoriza as referências culturais do país. É o perfil do brasileiro que se reconhece em meio aos múltiplos cenários produzidos pela ampla diversidade dos recursos naturais e culturais do Brasil. O discurso cultural oferece a lente que transforma e traduz todos os assuntos, constituindo, assim, a principal marca do estilo do programa. 


\section{REFERENNCIAS}

BORDENAVE, Juan E. Diaz. O que é comunicação rural. São Paulo: Brasiliense, 1983.

ERBOLATO, Mário L. Técnicas de codificação em jornalismo. São Paulo: Ática, 2002.

HALL, Stuart. The Work of representation In:

Representation: cultural representations and signifying practices. London: Sage; The Open University, 1997. 400 p.

HALL, Stuart et al. A produção social das notícias: o 'mugging' nos media In: TRAQUINA, Nelson (Org.). Jornalismo: questões, teorias e <<estórias〉>. Tradução de Luís Manuel Dionísio. Lisboa: Vega, 1993, p. 224-248.

HARTLEY, John. Understanding news. London: Routledge, 2001. 203p.

MAIA, Jussara Peixoto. Jornal Nacional e Globo Rural: sob o olhar das relações entre gênero e modo de endereçamento. 2005. Dissertação. (Mestrado em Comunicação e Cultura Contemporâneas) - Faculdade de Comunicação, Universidade Federal da Bahia, Salvador.

TRAQUINA, Nelson (Org.). Jornalismo: questões, teorias e <<estórias〉>. Tradução Luís Manuel Dionísio. Lisboa: Vega, 1993. VÉRON, Éliséo. Esta ahí, lo veo, me habla. Tradução Maria Rosa Del Coto. Enunciacion et cinema, Revista Comunicativa, Seul, Paris, n. 38, 1983. 


\title{
Cidade Alerta: jornalismo policial, vigilância e violência
}

\author{
Dannilo Duarte Oliveira
}

INTRODUÇÃO

O telejornal Cidade Alerta foi ao ar pela primeira vez no final de 1995, exibido pela Rede Record de Televisão e deixou de ser transmitido para todo o Brasil no dia 03 de junho de $2005^{1}$. O Cidade Alerta é um telejornal do subgênero jornalismo policial, considerado um programa temático de teor sensacionalista e espetacular nas notícias, em que a violência urbana está sempre em primeiro plano. Embora o telejornal apresente uma pauta flexível, a predominância das notícias sobre polícia/segurança é o que confere o tom ao telejornal, pois o foco do programa está na violência urbana.

Em função de ter permanecido mais de dez anos em exibição, o telejornal já possuía uma grande estrutura, dispondo de dois helicópteros chamados de Águia Dourada I e II, equipados com o que há de mais moderno em tecnologia para a geração e a transmissão de imagem e som. Os helicópteros carregam cerca de $300 \mathrm{~kg}$ de instalações, entre transmissores, câmeras e consoles de controle e manutenção. O Cidade Alerta contava ainda com cinco motolinks a sua disposição, sendo pioneiro no uso deste equipamento no Brasil. O objetivo maior era o de facilitar o acesso aos locais dos acontecimentos, com maior rapidez, pois motocicletas equipadas com câmeras, microfones e links de transmissão possibilitavam aos repórteres e cinegrafistas fugirem dos engarrafamentos².

1 Devido à queda de audiência do telejornal Cidade Alerta, outro programa entrou em rede nacional no seu lugar, a revista eletrônica Tudo a Ver, sob a liderança do jornalista Paulo Henrique Amorim.

2 A necessidade dos equipamentos de motolinks, para fugir dos engarrafamentos, justifica-se pelo fato de que a maior parte da cobertura jornalística ficava restrita à cidade de São Paulo, 
O primeiro conjunto de edições selecionadas para a análise foi exibido a partir das 18h e é referente aos meses de abril, maio e junho de 2004. Cada edição teve a duração de 1 hora e foi rodada no cenário original do programa.

O segundo conjunto de edições foi mostrado no mês de maio de 2005, com uma duração de apenas 30 minutos, que ia ao ar das 18h às $18 \mathrm{~h}$ 30min. Nesse período, o cenário do Cidade Alerta foi completamente reformulado seguindo as alterações realizadas também no Jornal da Record.

A escolha destes períodos justifica-se por dois motivos: primeiro, por que foi a época em que iniciamos a pesquisa sobre o telejornalismo policial e conseguimos gravar uma grande quantidade de edições do programa, totalizando 40 horas; segundo, por que a outra fase do programa serviu para fazer uma comparação entre as edições exibidas na primeira versão do programa, com duração de 1 hora, e na nova versão, com duração de 30 minutos e cenário reformulado. A partir daí, buscamos observar se houve alteração na programação do telejornal, além do tempo de duração e do novo formato do cenário.

\section{ESTRATÉGIAS DE ENDEREÇAMENTO DO CIDADE ALERTA}

Para uma análise aprofundada do Cidade Alerta nos apoiaremos numa abordagem dos aspectos comunicacionais, semióticos, ideológicos, históricos e culturais. O nosso estudo leva em conta todos os elementos que fazem parte do telejornal, desde a emissora em que é exibido, a linguagem televisiva utilizada, até a sua vinheta de abertura.

A vinheta de abertura do telejornal na versão de 2004 sugere e antecipa que tipo de programação o telespectador vai encontrar. Com uma duração de 10 segundos, ela começa com um voo rasante do helicóptero Águia Dourada sobre a cidade de São Paulo, para dar o tom de agilidade do programa; em seguida, é mostrada a imagem por terra da metrópole, com um trânsito denso, engarrafado. Nesse momento, aparece a imagem de uma motolink com uma equipe do programa, reforçando o caráter de agilidade na cobertura das notícias, pois o equipamento está apto para fugir dos engarrafamentos e chegar ao local das notícias com rapidez. Um tom de alerta, tensão e emergência, é acrescentado à vinheta com 
o som de uma sirene de polícia, e na sequência das imagens, aparece uma viatura da polícia em operação, mostrando ao lado uma motolink, sugerindo que o telejornal estará onde a polícia estiver, perseguindo os “criminosos". Novamente aparece o helicóptero Águia Dourada sobrevoando a cidade de São Paulo, mostrando uma imagem panorâmica da metrópole. Os movimentos da aeronave são rápidos para causar excitação no espectador, além de criar um ar de vigilância e perseguição. $\mathrm{O}$ Águia Dourada vai se aproximando ainda mais no vídeo, com uma imagem em close, parece que o bico da aeronave quer romper a tela da TV e, de repente, há um corte da imagem em close da aeronave para fechar no nome do programa. Este por sua vez vai aparecendo em perspectiva, de letra em letra, com escritura em caixa alta e em duas linhas. As duas palavras que intitulam o telejornal são separadas por um contorno, no formato de edifícios sombreados, remetendo, mais uma vez, a uma grande cidade que é vigiada. As cores da vinheta em tons de azul, prata, vermelho e lilás são as mesmas que compõem o cenário original do programa. Ao fundo da escritura, em segundo plano, temos um recorte da cidade de São Paulo. A vinheta de abertura manteve-se inalterada na versão mais atual do programa.

A vinheta de abertura do programa instaura as estratégias de legitimação do telejornal: vigilância, perseguição e agilidade na construção da notícia. Estas estratégias, além de anteciparem parte da promessa (JOST, 2004b) ${ }^{3}$ que o programa pretende realizar com o telespectador, servem para produzir um efeito de credibilidade e de realismo em suas narrativas.

No primeiro período de gravação, em 2004, o telejornal era formado por três blocos, sendo o primeiro com aproximadamente 30 minutos e o segundo e terceiro blocos com uma duração média de 20 minutos. Durante a apresentação do programa só são mostrados três intervalos comerciais, geralmente com um único anunciante, a loja Casas Bahia ou a loja Insinuante, o que indica o perfil da audiência, um público telespectador composto principalmente pelas classes C, D e E, haja vista que os

3 Para melhor entender como o "modelo da promessa" de Jost (2004b) é utilizado nesta análise, ver Dannilo Duarte Oliveira (2007). 
anunciantes são reconhecidos como lojas populares e de crediários longos.

O cenário do programa coloca-se como um recurso a serviço da linguagem televisiva, pois ele serve para determinar os lugares de fala com a audiência e o contexto comunicativo que vai ser manifestado a partir desta premissa. Na versão original do programa, o cenário é um espaço limpo, em tons de azul, prata, vermelho e lilás, com a disposição de poucos objetos.

Szpacenkopf (2003) afirma que na apresentação das notícias está incluído o cenário, que não deve ser esquecido e muito menos negligenciado. Do cenário fazem parte os apresentadores, suas roupas, o décor, o horário, as vinhetas, a hierarquização das notícias em relação às outras, além da própria cena da informação. Geralmente são cenários frios, do tipo clean, assépticos e neutros, auxiliados por tons das cores cinza e azul, que destacam o apresentador e fazem uma diferenciação entre estúdio e informação com imag’ens externas.

Vale ressaltar que as cores do cenário são importantes mediadores sígnicos. Segundo Luciano Guimarães (2003, p. 21), a cor é um dos mediadores sígnicos de recepção mais instantânea na comunicação jornalística e, mesmo assim, sua expressão não vem sendo utilizada com muita eficiência e respeito aos critérios que definem o jornalismo de qualidade. Ele defende que a expressão das cores é construída sobre a estrutura de códigos culturais, pois

[...] a recepção eficiente da informação cromática em veículos jornalísticos depende das informações externas à própria cor, como a contextualização da informação, o estudo do ambiente cultural, as diretrizes e os paradigmas que direcionam consciente ou inconsciente a utilização das cores nas informações veiculadas. (GUIMARÃES, 2003, p. 21)

Desta forma, é comum o uso de cores recorrentes nos programas jornalísticos, a exemplo da cor azul, que faz parte da maioria dos cenários dos programas jornalísticos, por se tratar de uma marca culturalmente reconhecida pela audiência. Portanto, cabe lembrar que "a própria ex- 
pressão das cores deve ser pensada como uma estrutura que se adapta ao veículo/suporte da comunicação, aos objetivos e às intenções dos meios de comunicação e ao meio cultural no qual é gerada e no qual atua". (GUIMARÃES, p. 21)

Podemos perceber a utilização de cores mais quentes, como a vermelha, no Cidade Alerta, por se tratar de um programa com a temática policial e, consequentemente com a associação da cor vermelha com a violência, a urgência e o perigo. A utilização de cores dentro deste programa vai desde os tons e texturas do cenário, do figurino do apresentador, às cores e formas das vinhetas de abertura e encerramento do programa ou de seus blocos, do uso de gráficos, infográficos, legendas etc. Portanto, Guimarães (2003, p. 31) considera a cor como informação todas as vezes em que sua aplicação desempenha uma função responsável por organizar e hierarquizar informações ou lhes atribuir significado.

Ainda com relação ao cenário do Cidade Alerta, aparece ao fundo uma grande tela retangular, que é composta por quatro telas menores, nas quais são projetadas as matérias exibidas durante o programa, e duas telas menores que pouco são mostradas nos enquadramentos, uma à direita e outra à esquerda do apresentador. Além das telas menores, o espaço apresenta várias barras metálicas tubulares ao lado das laterais do grande telão e das telas menores, o que proporciona ao cenário um ar de modernidade.

Outro ponto interessante no cenário é a ausência da bancada, uma tendência que se apresentava em programas mais antigos e consagrados como, por exemplo, Aqui Agora e Globo Repórter. Este modelo de cenário permite que o âncora obtenha uma performance corporal maior, permitindo que desempenhe um papel de apresentador de um jornalismo show. A visão que o telespectador tem do cenário no vídeo é de um espaço compacto, isso porque os movimentos de câmera dentro do programa são bem tradicionais, ancorados basicamente no plano americano (PA) e no primeiro plano (PP).

As equivalências entre os planos da câmara e a distância interpessoal vão desde a distância íntima - que corresponde ao primeiro plano - até a social. O plano americano (enquadramento até a cintura) representa a 
distância pessoal, a da comunicação cara a cara, que implica uma distância maior que a íntima, mas que admite, por exemplo, o contato de mãos entre os interlocutores. A distância social - que é a imposta por um objeto qualquer entre os interlocutores - teria seu equivalente no plano médio (os personagens aparecem de corpo inteiro). E a maior das distâncias - entre o público e o apresentador - é a distância pública que corresponde ao plano geral (em que se podem visualizar o cenário e os personagens por completo), mas, sem dúvida, os enquadramentos em plano americano são os mais utilizados no jornalismo televisivo, pois detêm a chamada distância pessoal em relação ao telespectador. (MACHADO, 1996, p. 105-106)

Como ressalta Szpacenkopf (2003), os cenários são feitos para destacar o apresentador, como o que ocorre com Marcelo Rezende, âncora do Cidade Alerta, que mantém uma postura de destaque no vídeo. As notícias são apresentadas por ele de pé, uma forma de ganhar um poder maior de expressão diante das câmeras, o que o coloca numa condição de ser mais teatral na sua performance cênica no momento em que expõe as notícias e que tece seus comentários. Além disso, o fato de estar de pé permite que o apresentador tenha maior mobilidade no cenário e maiores possibilidades de enquadramento, aproximando-se e afastando-se da câmera durante todo o programa.

Este comportamento de Rezende só é possível graças aos códigos televisivos que são constituídos a partir dos códigos sociais e culturais preexistentes que de alguma forma foram internalizados pelos programas jornalísticos deste tipo e pela audiência. Esses códigos da linguagem televisiva são redes de relações entre os produtores, os textos e as audiências, que funcionam como agentes de intertextualidade através dos quais os textos se inter-relacionam e produzem significados que constituem um processo próprio do gênero televisivo, que se atualiza constantemente.

Essas mudanças e atualizações podem ser percebidas na versão reformulada do programa, com um cenário um pouco mais moderno, também compacto, mas com uma característica de maior limpeza. Ao fundo, o grande telão foi substituído por quatro modernas telas de plasma, penduradas em duas colunas metálicas em tons de prata. O programa 
apresenta um cenário ainda mais clean, com tons em azul, cinza, prata e, levemente avermelhado, próximo ao nome do programa. Na parte superior, ficam penduradas duas telas que exibem sempre o nome e o layout do programa. Já na parte inferior das colunas, ficam penduradas as outras duas telas, nas quais são rodados os VTs que são acompanhados pelo apresentador. Na parte inferior do canto esquerdo do vídeo, fica novamente a inscrição do nome do programa.

Fora os elementos físicos que compõem o cenário, há um pequeno caractere na parte superior direita do vídeo: uma pequena vinheta em que está escrito "Exclusivo", que fica piscando com o objetivo de chamar a atenção dos telespectadores, uma forma de dar às notícias a ideia de que são em primeira mão ou de última hora, ou simplesmente de que só o programa Cidade Alerta dispõe daquelas imagens naquele momento. Outro caractere aparece na parte inferior do vídeo, de forma centralizada, com a inscrição do layout do programa e as manchetes que vão sendo apresentadas. Por sua vez, as manchetes geralmente são textos curtos e de impacto que conduzem interpretações e demonstram parcialidade, apresentando um resumo sensacionalista das notícias que são chamadas pelo apresentador. Por fim, ainda na parte inferior do canto direito do vídeo aparece o logotipo da emissora, atestando a credibilidade do conteúdo por meio do veículo mediador.

De fato, as únicas mudanças substanciais nas versões de 2004 e 2005 do Cidade Alerta foram no cenário e no tempo de exibição do programa, que foi reduzido. As estratégias de endereçamento e a linguagem televisiva adotadas pelo telejornal continuaram as mesmas em ambas as versões.

\section{A PERFORMANCE CÊNICA DO MEDIADOR E O TEXTO VERBAL}

Idealizador e ex-apresentador do programa Linha Direta da Rede Globo, Marcelo Rezende perdeu interesse pelo dito programa, quando se viu limitado à função de apenas apresentador, sem poder comentar ou fazer reportagens de rua. Ao mesmo tempo em que acalentava o sonho de se tornar âncora de um telejornal, ele admitiu que sua vocação para 
a reportagem não podia ser exercida no Linha Direta, programa em que trabalhou por mais de dois anos.

Gostava do programa quando eu podia entrevistar os suspeitos na delegacia. Depois disso, minha atuação ficou restrita à apresentação. Acabei perdendo o interesse [...]. Em muito pouco tempo, o jornalismo ancorado vai imperar na tevê. Afinal, o âncora leva para o telejornal toda sua credibilidade como repórter [...]. Já fiz muita coisa na vida. Mas reportagem de rua é o melhor que tenho a oferecer. Não posso abrir mão disso ${ }^{4}$.

Estes motivos expressados parecem convincentes para justificar a sua saída da Rede Globo e do comando do Linha Direta. No entanto, no prefácio do livro de Kleber Mendonça sobre o programa, o escritor Nilo Batista atribui outros motivos que apressaram a saída de Marcelo Rezende da Rede Globo:

Pouca gente sabe por que Marcelo Rezende foi substituído por Domingos Meirelles. É que, em 25 de novembro de 1999, a juíza da $12^{a}$ Vara de Família do Rio determinara a intimação de Marcelo Rezende, por edital, para submeter-se a exame de DNA numa ação de reconhecimento de paternidade, que aliás seria julgada procedente em primeira instância: estava ele na situação de 'residência incerta e não sabida', como rezava o edital, tal e qual suas vítimas. O implacável perseguidor de foragidos também era, de certa forma, um homem procurado pela justiça (MENDONÇA, 2002, p.15)

De perseguidor e inquisidor de bandidos, Marcelo Rezende tornou-se, inacreditavelmente, um procurado pela justiça para dar explicações sobre um reconhecimento de paternidade. Tal ocorrência pode ter sido, de fato, o real motivo do ex-apresentador do Linha Direta ter deixado o cargo e a Globo.

Em fevereiro de 2004, após rescindir contrato com a Rede TV!, Rezende fecha contrato com a Rede Record e passa a apresentar o programa Cidade Alerta, que anteriormente era comandado por José Luis Datena. Como âncora do Cidade Alerta, Marcelo Rezende emplacou um estilo de

4 Entrevista de Marcelo Rezende para o jornal Correio Brasiliense, em 23 de junho de 2002. 
caça aos bandidos, adotando uma postura firme e com comentários veementes sobre o mundo do crime. Rezende não economizava nas palavras, na oratória e muito menos na expressão corporal, para manter a audiência do programa. Desta forma, a voz-guia do apresentador torna-se, como sugerem Itania Gomes e colaboradores (2003, p. 8), “[...] onipresente e ofegante, em tom elevado e com pouca pausa entre as palavras é, sem sombra de dúvida, uma das marcas fortes do programa, tornando relevante o aspecto sonoro do Cidade Alerta".

O apresentador costuma encenar gestos agressivos diante das câmeras, mostrando-se irritado com alguns fatos, uma maneira de dar ênfase a determinadas notícias ou a comentários emitidos por ele, além de tentar mostrar aos telespectadores que ele também se indigna com os problemas sociais. No entanto, o seu comportamento agressivo é parte da estratégia retórica do programa, uma maneira de endereçamento comum do Cidade Alerta. O âncora explora o corpo como modalizador discursivo que contribui no texto verbal, e também a maneira de olhar do apresentador, como tática para o estabelecimento do pacto entre ele e a sua audiência.

Quando o mediador mira os olhos no espectador, é um olhar direto, incisivo, persuasivo que combina com sua expressão facial indig'nada e coerciva, auxilia na identificação do tom do programa que busca uma postura de vigilância para com sua temática: a questão da violência física contra o cidadão de bem, especificando a luta diária 'maniqueísta' entre policiais (mocinhos) e assaltantes/ assassinos/ traficantes (bandidos) nas grandes metrópoles. (GOMES et al., 2003, p. 7)

Eliseo Verón (1983), ao tratar da gestualidade e do posicionamento diante das câmeras pelos apresentadores de programas televisivos, estabelece duas classificações: o "apresentador ventríloquo", que funciona apenas como um ponto de passagem para o discurso factual e descritivo; e o "apresentador moderno" ou "meta-enunciador" que se expande por meio da dimensão corporal. Neste caso, todo o corpo do apresentador é midiatizado como estratégia de interpelar e aproximar ainda mais o telespectador. Segundo Verón (1983, p. 13), o apresentador, por meio do 
corpo midiatizado, vem acompanhado de uma expansão do cenário, que ganha profundidade e arquitetura e uma maior variedade de movimentos de câmera. À primeira vista, o apresentador do Cidade Alerta se comporta como "apresentador moderno", porém, no programa, a complementação do desempenho do apresentador não é acrescida pelo cenário, pois o mesmo é muito compacto e os movimentos de câmera são restritos basicamente ao plano americano e ao primeiro plano. Esta característica também é válida, por exemplo, para o telejornal Brasil Urgente da Rede Bandeirantes de Televisão. O modelo de "apresentador moderno" ou "meta-enunciador" verifica-se melhor em programas como o Linha Direta, Globo Repórter e Fantástico, por exemplo, em que os cenários são amplos e os variados movimentos de câmera complementam o desempenho dos mediadores, que andam de um lado para o outro e são mostrados de corpo inteiro, com aproximações em close.

Portanto, os modelos de apresentadores propostos por Verón ajudam a compreender as características do mediador nos programas jornalísticos, no entanto, não são suficientes para dar conta da corporalidade do apresentador do Cidade Alerta. Isto posto, recorreremos a outra instância de modelo de análise do mediador, para verificar o desempenho do apresentador no programa, que supera as limitações do cenário compacto e dos poucos enquadramentos de câmera. Denominaremos o modelo de "mediador performático" ou "performance cênica do mediador". O que consideramos por performance cênica refere-se ao modo do apresentador se comportar, como expressões faciais, modalização da voz de forma eloquente, uma performance corporal com movimentos mais expansivos e agitados, sem precisar ser auxiliado, necessariamente, como indicava Verón (1983) por cenários amplos que dão profundidade às ações do mediador e variados enquadramentos de câmera, como é o caso da performance de Marcelo Rezende no compacto cenário do Cidade Alerta.

Boa parte da comunicação interpessoal não se dá apenas pela fala, mas, sobretudo, por meio dos gestos. Desta forma, os movimentos corporais configuram-se como uma estratégia discursiva que transforma o objeto corpo em linguagem. Assim, no jornalismo como na publicidade, a figurativização do corpo é um elemento central devido à importância 
que a imagem possui na linguagem televisiva. Os processos de manifestação do corpo, especialmente na televisão, trabalham como elementos de persuasão e de estímulo, estrategicamente sobre o público-alvo como modo de agregar valor ao produto (discurso jornalístico) ou marca, daí a necessidade de analisar mais detidamente a expressão corporal do mediador do Cidade Alerta por meio de sua performance.

De acordo com Garcia (2005), toda atividade humana com o corpo requer uma performance, já que esta ocorre com base na ação do homem. A performance corporal deve ser percebida como (experiment)ação cênica que pode ser conciliatória e/ou provocativa. Uma atitude performática apresenta-se como ação (inter)mediadora, sendo assim:

[...] a construção da performance e sua inscrição (dis)juntiva, fica evidente que a ação performática se estrutura pelas superposições de escrituras flexíveis e polissêmicas, caracterizadas como: o modo de falar e de agir, a participação do ator e/ou do público, que deve ser socialmente construída; o deslocamento das narrativas abordadas entre performer e público, bem como o uso de locais alternativos, que favorecem o improviso advindo de uma rápida preparação - o ensaio. Em outras palavras, as variantes que estabelecem uma performance compõem-se de valor poético, próprio de sua intenção transideológica, invocando a cômoda participação do público. Estímulos, provocações e inquietações são ingredientes estratégicos da performance para ativar a participação do público. (GARCIA, 2005, p.127)

Portanto, é a partir desta noção de performance que buscamos compreender a capacidade cênica desempenhada pelo mediador do Cidade Alerta, enquanto uma estratégia de interação e mediação por meio do corpo. Com o auxílio da performance corporal, o apresentador vai se valer, também, de um texto verbal adequado à sua postura corporal no vídeo.

O mundo da televisão é por si só um ambiente flexível e polissêmico, especialmente na forma de falar e agir, seja dos atores, apresentadores e jornalistas. É comum Marcelo Rezende utilizar-se de um discurso provocativo e demonstrar-se inquieto com a realidade social, elementos que 
fazem parte da sua estratégia de interpelação da audiência. A linguagem verbal utilizada por Marcelo Rezende expressa para quem o programa é endereçado, pois ela é corriqueira, direta, incitante, provocativa, com o uso de muitas gírias e também com o uso do apelo emocional nos textos. O uso de expressões g’eneralizadas e carregadas de adjetivação é uma constante, pois Marcelo Rezende costuma se referir aos acusados dos crimes nas matérias como bandido, assassino, estuprador, criminoso, cretino, cara de pau, monstro, drogado, pervertido, entre outros adjetivos.

O mediador, no momento em que apresenta um dos acusados no seu telejornal, mostra-o já como culpado, mesmo antes dele ter sido julgado. Este tipo de relação se coloca como um problema entre o telejornal e a justiça, pois o programa realiza um julgamento virtual que, certamente, poderá interferir nos resultados dos julgamentos nos tribunais reais.

O âncora, ao adjetivar os acusados e se colocar como uma autoridade no assunto tratado, posiciona-se no lugar de juiz da sociedade, substituindo ou tentando substituir as instituições do judiciário, ou assumindo o papel do próprio Estado, que controla e disciplina os desvios sociais. O Cidade Alerta propõe um pacto com a audiência de um jornalismo de vigilância, denúncia e prestação de serviço social. Desta forma oferece ao repórter o papel do vigilante da sociedade: está ali para acompanhar e denunciar as falhas dos sistemas sociais públicos e privados, alertando a sociedade sobre os riscos que corre e chamando-a para a ação social. O Cidade Alerta assume essas características, deixando transparecer a noção de quarto poder tão requerida pelo jornalismo. Esta relação de quarto poder vai sendo estabelecida à medida que o programa vai se desenvolvendo e está na maneira como o programa se relaciona com a sua audiência.

Marcelo Rezende está posicionado como o representante do telejornal, ele age com um tom doutrinal e de autoridade que é produzido pela situação comunicativa estabelecida pelo telejornal. Fica evidente a noção hierárquica ocupada pelo apresentador (enunciador) e pelos telespectadores (enunciatários) no contexto comunicativo do programa. Para demonstrar o ar de autoridade que julga e sentencia os criminosos e a postura de doutrina do apresentador, apresentamos os julgamentos 
que Rezende faz dos acusados e as recomendações que faz para o público acerca dos problemas sociais.

Cabeça de matéria - Um homem, um criminoso, saiu da cadeia por causa do indulto de Páscoa, na rua ele encontra um grupo de bandidos, que ele conhecia, antes eles eram amigos. Ele foi cercado e assassinado com vários tiros nas costas ${ }^{5}$.

Comentário - O que parecia inofensivo numa cadeira de rodas $[. .$. Ele tem que ser execrado e banido de uma vez por todas da vida em comum com a gente. Deus não dá asa a cobra, já o marcou e o deixou numa cadeira de rodas depois de um acidente, por que boa coisa ele não tinha. Eu na verdade queria que os dois fossem pro inferno $^{6}$.

Comentário - Aí tem um monte de assassino, eu não posso dizer que é assassino. Mas o Percival tem o dado exato [...] Quer dizer que $12 \%$ são assassinos, de cada 100 doze já mataram, doze, doze já mataram a faca, de revolver, ou a paulada. Este é o retrato de uma instituição falida de um Governo do Estado fraco e sem autoridade. Porque são vinte e oito rebeliões e você não escuta o governador do Estado dizer: eu vou mudar e mudar com disciplina. É só desculpa, conversa e não se tem nenhuma mudança ${ }^{7}$.

Nota-se nos trechos das falas do apresentador o uso de expressões comuns e o uso de adjetivação e incriminação dos acusados. O uso de adjetivação reforça o caráter inquisidor tomado por ele: antes dos supostos culpados serem julgados, Marcelo Rezende sentencia e adjetiva os envolvidos. Outra característica de seus comentários é a crítica às autoridades e à Justiça, por abusos ou por negligência, ou seja, o programa assume o lugar de prestador de serviço para a sociedade de forma alerta e vigilante. De acordo com Guilherme Jorge de Rezende (2000), o comentário é um gênero jornalístico opinativo e que é evidenciado pela interpretação que um jornalista ou especialista faz sobre um determinado assunto.

5 Programa Cidade Alerta, exibido em 22 abr. 2004.

6 Programa Cidade Alerta, exibido em 27 abr. 2004.

7 Programa Cidade Alerta, exibido em 20 mai. 2005. 
"Em sua apreciação, o comentarista muitas vezes orienta o público, que pode conferir ao seu trabalho uma conotação de jornalismo de serviço". (REZENDE, 2000, p.158) Esta noção de prestação de serviço à sociedade é um dos pactos sobre o papel do jornalismo firmado entre o programa e a sua audiência.

Sempre que chama alguma matéria ou faz algum comentário, Marcelo Rezende convoca o telespectador e diz: "agora vem para mim”, "agora pensa numa situação", "quero dizer o seguinte", "eu vou contar uma coisa para você", "vem aqui por favor", o âncora interpela o telespectador a prestar atenção em suas palavras. Simultaneamente, as câmeras do estúdio fecham a imagem em primeiro plano no apresentador, para criar um grau maior de intimidade e ratificar a promessa e o pacto com a audiência. Outra característica do texto do programa e dos comentários de Marcelo Rezende é o apelo emocional, mostrando o sofrimento das vítimas ou dos parentes, a construção dramática da narrativa, e a busca sensacionalista da humanização do relato.

Cabeça de matéria - Vou falar de um assunto agora que se eu chorar paciência. Porque sempre que eu falo nesse assunto eu acabo chorando pelo grau de amizade que eu tinha. Eu já comecei a desmoronar. Dois de junho de 2002. O repórter Tim Lopes sobe um dos morros do Complexo do Alemão. Ele sobe um dos três morro [...]. Nesse momento, em que ele está sentado em um bar, era a terceira vez que ele ia ao local, passa um sujeito chamado Ratinho, que tinha sido preso na primeira reportagem. Ratinho, tinha sido preso, ele que era traficante, quando ele passa encontra Tim Lopes. E diz: eu não te conheço?... A primeira coisa que aconteceu com ele foi o seguinte: Ratinho não lhe deu 30 segundos para responder. Pegou e disparou uma arma no joelho dele. Imediatamente levaram ele para cima do morro e este débil mental (mostra imagem de Elias Maluco no telão) Elias Maluco, pegou uma tacuma, que é um sabre japonês, com essa cara de infeliz e fez a seguinte coisa: com o sabre japonês, Tim Lopes vivo com a perna sangrando pelo tiro, enfiou a espada nele e começou a rodar e todos eles começaram a debochar e dizer: agora você vai pagar, você vai pagar pela matéria que você fez... Mas não bastava para esse débil mental, me dá o débil 
mental por favor (pede a imagem de Elias Maluco no telão). Não bastava para Elias Maluco só isso. Ele pegou uma pilha de pneus, colocou o Tim Lopes ainda vivo e atirou fogo. Sentaram e ficaram assistindo sob o comando de Elias Maluco. O repórter Tim Lopes morrendo devagar. Hoje começou por que o Estado de Direito determina o julgamento do traficante Elias Maluco, que pode pegar só 39 anos de cadeia apenas, com todos esses recursos possíveis pode pegar 6 anos, depois do que fez a um profissional, a um chefe de família [...]. Sabe como eles atiraram fogo no corpo, pois eu deixei para o final. Ratinho pegou acendeu o cigarro e jogou na gasolina que estava dentro do que eles chamam de micro-ondas. Eu pergunto é preciso ou não ter uma pena definitiva no nosso pobre e corrupto Brasil, não é? ${ }^{8}$

Após mais de dois anos do assassinato de Tim Lopes, Marcelo Rezende atualiza o tema com a convocação da Justiça para o julgamento de Elias Maluco. A cabeça da matéria se parece mais com uma história de ficção policial devido aos detalhes apresentados pelo âncora do Cidade Alerta. O apresentador interpela o telespectador, inicialmente por meio de um texto emotivo e carregado de dramaticidade, como estratégia para prender a sua atenção. Ao longo do texto, Marcelo Rezende vai costurando retoricamente argumentos para que possam dar a ele subsídios capazes de, ao final de sua fala, defender a pena de morte no Brasil, penas mais duras, as quais ele não esclarece. Fica evidente, por meio do discurso do âncora, quais são os seus posicionamentos ideológicos e políticos, a exemplo da defesa da pena de morte, que, segundo ele, resolveria todos os problemas da violência.

Cabeça de matéria - Vem aqui por favor, pensa numa questão. São duas irmãs, uma está desempregada. Ela está desempregada e as duas tem uma amiga. Uma amiga que é chegada nesse negócio de Vodu, magia negra, uma novela do tamanho de um bonde. De repente, uma irmã convida a outra para um ritual de magia negra para conseguir um emprego para ela. Mas ali estava preparada uma armadilha. A irmã atraiu a outra e aí quando começa o ritual de

8 Programa Cidade Alerta, exibido em 23 mai. 2005. 
magia negra ela dá vinho para irmã tomar, o vinho tinha veneno.

Era apenas o início de um ritual de magia negra que levaria a irmã

Cláudia a morte. Põe no ar! ${ }^{9}$

Como apoio às opiniões emitidas pelo apresentador, existe outro personagem que faz parte do telejornal Cidade Alerta, o jornalista policial e advogado Percival de Souza, que aparece no vídeo em poucos momentos, apenas quando é chamado para servir de consultor jurídico a Marcelo Rezende, para tirar dúvidas a respeito de crimes, punições, artigos judiciais, ou até mesmo para emitir juízo de valor sobre determinado assunto. Uma informação importante é que Percival de Souza lançou em 2002 o livro Narcoditadura: o caso Tim Lopes, crime organizado e jornalismo investigativo no Brasil. Provavelmente, os detalhes apresentados por Marcelo Rezende na edição do dia 23 de maio de 2005 sobre o caso Tim Lopes foram baseados no livro. Desta forma, percebe-se que o apresentador "juiz" recorre a um jornalista e advogado especializado em denúncias, crimes e investigação, para legitimar seu discurso e o seu papel de benemérito da sociedade. O fato de Marcelo Rezende recorrer a um especialista em criminalística está ligado a uma estratégia do programa em dar credibilidade e autenticidade às informações trazidas ao público pelo telejornal e, especialmente, dar sustentação, ancoragem ao papel desempenhado por Rezende.

O programa, ao buscar fazer o papel de benemérito da sociedade, de paladino da justiça, ou de quem presta um serviço social de denúncia e vigilância, tenta se colocar acima do papel que caberia ao Estado, e é nesse momento que a noção de pacto sobre o papel do jornalismo fica mais evidente no telejornal. Portanto, o Cidade Alerta vai propor um pacto de que está vigilante, de olho no mundo do crime e nos tribunais para cobrar a condenação dos "criminosos" ou, simplesmente, para dizer ao telespectador que se o Estado não cumpre o seu papel, o Cidade Alerta está ali para cobrar explicações e exigir que algo seja feito.

Parte da credibilidade atribuída pela audiência a Marcelo Rezende está na sua capacidade retórica, por meio de uma argumentação, geralmen-

9 Programa Cidade Alerta, exibido em 20 mai. 2005. 
te ancorada em posicionamentos moralistas e reacionários, ao longo dos programas. Para exemplificar o desempenho retórico utilizado por Rezende, temos uma matéria que foi ao ar no dia 27 de abril de 2004, a manchete da matéria dizia: "Vizinho é acusado de violentar e matar garota". A matéria era sobre um deficiente físico, o Zé Aleijadinho, como era conhecido no bairro, que cometeu um estupro juntamente com o colega que cuidava dele. A vítima, Rita de Cássia Pontes, de 8 anos de idade, segundo o telejornal, foi violentada, estuprada e morta com oito facadas na cabeça. Ao final da matéria, Rezende faz o seguinte comentário:

Comentário - O que parecia inofensivo numa cadeira de rodas $[\ldots]$ Ele tem que ser execrado e banido de uma vez por todas da vida em comum com a gente. Deus não dá asa a cobra, já o marcou e o deixou numa cadeira de rodas depois de um acidente, por que boa coisa ele não tinha. Eu na verdade queria que os dois fossem pro inferno ${ }^{10}$.

Nota-se no comentário do apresentador que tipo de julgamento ele é capaz de fazer sobre os acusados, além do uso de uma linguagem popular e sensacionalista, coloca-se como um doutrinador. Para deixar a reportag’em ainda mais dramática, o apresentador chama um VT com imagens do pai da garota frente a frente com o "assassino" na cadeira de rodas. O pai pergunta ao acusado por que ele cometeu o crime. Em seguida o apresentador faz mais um comentário sobre o enterro da garota e diz: "o caixão da menina teve que ser enterrado lacrado, porque nem eu não consigo descrever como ficou o rosto da vítima”.

A edição da matéria procurou explorar as imagens do local do crime onde havia ainda muito sangue, na entrada da casa. Imagens do sofrimento da família no velório e no enterro e fotografias da menina também foram utilizadas para criar um clima de desespero e de revolta. A matéria termina com a imagem do chinelo ensanguentado que a garota usava no momento do crime, encontrado dentro da casa do Zé Aleijadinho. Este caso fica no ar por mais de 20 minutos, sendo a matéria repetida três vezes durante a edição, seguida de comentários de Rezende. A repetição

10 Programa Cidade Alerta, exibido em 27 abr. 2004. 
das matérias várias vezes dentro de uma mesma edição é uma marca do Cidade Alerta e auxilia no reforço da informação para a audiência, além disso, possibilita que o apresentador opine ainda mais sobre os casos mostrados.

Outra questão importante no dia a dia de produção do Cidade Alerta é a relação com as fontes de informação. Como esclarecem Itania Gomes e colaboradores (2003, p. 4)

[...] o Cidade Alerta se beneficia de um bom relacionamento construído com o meio policial, o que lhe garante vários 'furos' e a possibilidade de acompanhar e transmitir ao vivo as ações policiais, algumas programadas para acontecer no horário da transmissão do programa.

A não existência de formato e duração padrão para as matérias, que podem durar 2, 10, 15 ou até 30 minutos, a depender do grau de sensacionalismo dado ao enquadramento da notícia e, especialmente, do poder retórico que Marcelo Rezende emprega sobre determinadas notícias, principalmente, quando se trata de coberturas "ao vivo", é outro aspecto relevante no programa. A duração das matérias é importante para pensar na capacidade performática e cênica do apresentador, que é quem vai segurar por mais ou menos tempo no ar determinadas notícias e fazer com que os telespectadores também continuem acompanhando a transmissão.

As entradas "ao vivo" no programa são muito comuns, aliás, o uso do "ao vivo" é uma das chaves do endereçamento do programa para a sua audiência. As transmissões "ao vivo", além de demonstrarem o poderio técnico da emissora e do telejornal, trazem consigo maior credibilidade e confiabilidade nas informações exibidas.

Desta forma, o "ao vivo" é uma das características essenciais do Cidade Alerta. Boa parte da programação diária do telejornal é permeada por tomadas "ao vivo" pelos repórteres. No período examinado, Eleonora Pascoal destacou-se, ao acompanhar o dia a dia da cidade de São Paulo, do helicóptero Águia Dourada. Ao mesmo tempo, uma equipe por terra vasculha a cidade com as motolinks que, geralmente, ficam acompa- 
nhando viaturas da polícia em rondas. A maior parte da cobertura "ao vivo" é de reportagens como acidentes de trânsito, perseguições de fugitivos da polícia, incêndios e deslocamentos de presos. Quando a repórter Eleonora Pascoal é chamada por Marcelo Rezende, ele a anuncia como se estivesse trazendo para a tela do telespectador grandes acontecimentos e notícias. No entanto, apesar da dimensão sensacional dada pelo apresentador, o "ao vivo" durante o programa cobre, frequentemente, procedimentos de rotina, como pontos engarrafados na cidade, chuvas e pequenos acidentes e rondas policiais à procura de fugitivos.

Podemos olhar esse formato de apresentação da notícia como uma estratégia retórica escolhida pelo jornal. Como vimos anteriormente, o Cidade Alerta não possui uma estrutura fixa de formato nas matérias, sendo o "ao vivo" a predileção do programa. A notícia no programa não segue uma linearidade, em muitos casos não apresenta uma conclusão, devido à entrada e à saída de câmeras, quando Marcelo Rezende diz, por exemplo, "me dê a Eleonora Pascoal que está ao vivo neste momento". Portanto, o formato "ao vivo" de transmissão da notícia parece consolidar um pacto implícito entre o programa e o público. No entanto, não é raro o programa mostrar uma matéria pré-gravada sobre um fato que ocorreu em um intervalo de tempo considerável, mas que na edição da matéria é dado um tom, uma sensação de atualidade e instantaneidade, como se o acontecimento se desenrolasse naquele momento.

Entendemos que a instantaneidade marca um ato comunicativo que não possui um dispêndio de tempo relevante na sua realização para descolá-lo do tempo da experiência presente em que a comunicação estiver ocorrendo. Mais especificamente, no jornalismo o caráter de instantâneo pode não ser real (pode haver um intervalo mínimo de tempo ocorrido), mas esta duração ínfima pode não ser significativa para interferir negativamente na construção que o jornalismo faz de conteúdos baseados e voltados para experiências no presente. (FRANCISCATO, 2003, p. 148-149)

Como exemplo, há uma matéria exibida no dia 14 de junho de 2004, com a seguinte manchete "Trabalhador corre perigo em andaime quebrado". A cobertura "ao vivo" foi da repórter Eleonora Pascoal, a bordo 
do helicóptero Águia Dourada e também com imagens terrestres geradas por uma motolink sobre a notícia de um homem que ficou pendurado num prédio no centro de São Paulo. Esta foi a última matéria do programa daquele dia e o apresentador ficou 44 minutos no ar, desses, 30 minutos sem cortes, até o momento em que os bombeiros resgataram o trabalhador.

Comentário - Repara olha o drama do cidadão porque, porque ele não consegue, fica aí paradinho, ele não consegue, repara, ele tá sentado aí esperando o Corpo de Bombeiro chegar, porque tá fechado o prédio. Ele entrou pela parte de cima, fui descendo na corda e num determinado momento, foi limpando janela por janela e agora ele não consegue voltar e também não consegue descer. E olha aí, você vê o tamanho da altura em que ele está. Nós estamos também mandando uma ULJ, olha o tamanho da altura. Os Bombeiros já estão no local e vai tentar entrar, não chegou escada magiros. O bombeiro vai tentar entrar pelo prédio e quebrar uma vidraça ou se não tiver cadeado pra resgatar o pobre do trabalhador nesse momento que está ali na angústia, se uma corda arrebentou, imagina que ele está pensando, outra corda pode arrebentar, eu tenho informações com Eleonora Pascoal $[\ldots]^{11}$.

Nota-se durante todas as falas de Marcelo Rezende que ele não dispõe de nenhuma informação bem apurada. O próprio comentário dele sobre o tipo de vidro utilizado no prédio é baseado nas imagens que ele está vendo no estúdio, a mesma imagem que chega para todos os telespectadores. Durante mais de 40 minutos, a estratégia utilizada por Rezende foi a de especular sobre as imagens e as poucas informações que chegavam para a produção do programa. É neste momento que a capacidade retórica do apresentador é evidenciada e consegue manter informada a audiência do programa.

As transmissões "ao vivo", por meio de equipes móveis formadas por jornalistas e cinegrafistas, possibilitam o aumento do valor da notícia em função do tempo economizado e da autenticidade com que a informação

11 Programa Cidade Alerta, exibido em 14 jun. 2004. 
é transmitida. Daí, portanto, o fato de Rezende ter ficado tanto tempo no ar com a matéria, explorando uma das premissas do jornalismo, a veracidade da notícia. A exibição da notícia mostra ainda a capacidade técnica de cobertura "ao vivo", as ações dos bombeiros ou, em outros casos, as ações da polícia na cidade de São Paulo.

O texto verbal dos repórteres acompanha o estilo do texto do âncora do programa, com o uso de adjetivos, de expressões comuns, apelo dramático e uma linguagem sensacionalista, o que ratifica a promessa expressada pelo telejornal. O tom sensacionalista é dado pelo repórter que prepara as matérias com uma estrutura narrativa dramática e envolvente, estando presentes nos textos das matérias elementos como a curva dramática, o clímax e os desdobramentos da notícia. (MARFUZ, 1996)

Todos esses repórteres têm características em comum, como o uso de uma linguagem simples e de palavras sensacionalistas, e o costume de fazer as passagens ${ }^{12}$ no local em que foram praticados os delitos, mostrando muito sangue, imagem de corpos pelo chão ou sendo carregados pela polícia. Além disso, há a busca de apelo emocional nos textos e a humanização do relato por meio de entrevistas com parentes das vítimas ou com as próprias vítimas. A matéria exibida no dia 23 de abril de 2004, uma sexta-feira, começa mostrando o sangue da vítima que escorre pelo chão. O texto diz que a jovem de 17 anos levou um tiro no ouvido, que partiu o brinco que a mesma usava. O repórter faz a passagem no local em que a vítima foi assassinada.

Off $1^{13}$ - Um tiro no ouvido dividiu o brinco em duas partes, e matou Érica. Outros sete tiros foram só para aliviar a raiva. O assassino queria cobrar uma dívida, mas preferiu se apossar de uma vida [...].

Passagem - Ela desce apressada, pulando os degraus, sem saber que está sendo esperada. Bem aqui, encontra-se com a morte, sem nenhum grito, nenhuma discussão o assassino começou a atirar.

12 O termo passagem, na linguagem jornalística, é o momento em que o repórter aparece no vídeo para assinar a matéria.

13 O termo off significa, na linguagem jornalística, a gravação do texto (voz) da matéria pelo repórter em estúdio. 
Ele descarregou o revolver, pegou mais munição, recarregou a arma e continuou atirando à queima-roupa. Três tiros na cabeça, dois no abdome, dois nas nádegas e um na perna ${ }^{14}$.

Em meio ao texto, as imagens mostram o local do crime, marcado por uma poça de sangue em uma escada. Imagens do sofrimento da família são enfatizadas no vídeo, auxiliado por uma música de suspense, com vinhetas de tiros e gritos. Esse efeito sonoro conhecido como BG é um recurso largamente utilizado na edição das matérias do Cidade Alerta, pois os sons de tiros, sirenes, gritos e música de suspense dão um tom de realismo e de dramaticidade às matérias, buscando atrair ainda mais a atenção dos telespectadores. A imagem de uma região periférica e pobre da cidade de São Paulo ajuda a compor o clima de suspense, medo e violência.

Os espetáculos do sofrimento, morte, catástrofes e violência têm presença marcante nos telejornais. Atuais, ainda que repetitivos, habitam excessivamente noticiários, o que em nossa opinião fala mais do que uma questão de banalização. O excesso de violência na mídia deve-se ao fato não só de ela já fazer parte de um de seus agendamentos, mas porque constitui um dos temas que mais interessam ao espectador. (SZPACENKOPF, 2003, p. 253)

Em outras duas matérias, o recurso da simulação é fundamental para o telejornal explorar mais um elemento retórico. O uso da simulação torna-se uma ferramenta importante para o programa, pois este possui apenas o inquérito policial disponibilizado pelo Ministério Público. A reconstituição cumpre o papel de legitimação da verdade, cabendo a ela representar certa realidade. No entanto, a simulação no Cidade Alerta é feita de maneira muito rudimentar, sem preocupação com a forma (plasticidade) e com a narrativa.

O jornal faz a reconstituição inteira do crime por meio de uma simulação que mistura imagens reais do local do crime com imagens reconstituídas em estúdio. A simulação dentro do programa é a forma do tele-

14 Programa Cidade Alerta, exibido em 23 abr. 2004. Reportagem: Gustavo Gonçalves. 
jornal atualizar os conteúdos que vão ao ar, procurando dar a eles uma dimensão de factualidade, pois, em geral, os crimes aconteceram em um intervalo de tempo considerável e a produção do programa não dispõe de imagens sobre o caso, que é atualizado no momento em que o acusado é preso ou está sendo julgado.

Off 1 - reconstituição - Parece apenas um passeio. Éric e a mulher chegam em um local deserto. Ele está armado e Ana Paula vai ser assassinada com quatro tiros. Éric é metido a conquistador, não trabalha e ainda gasta com mulheres e bebidas o pouco dinheiro que a mulher Ana Paula ganha. Ela é garçonete em uma rede de lanchonetes [...] Éric vai embora e no caminho começa a planejar a morte de Ana Paula. [...] Ele a leva para um lugar deserto, saca a arma e mata Ana Paula com quatro tiros na cabeça. Cava um buraco e joga o corpo ${ }^{15}$.

Off 2 - "Este é o olhar de um assassino, de um criminoso frio que não demonstra arrependimento" 16 .

Entrevista - "Repórter: Você pensou em sua filha na hora de executar sua companheira com quatro tiros? Éric: permanece calado" ${ }^{17}$.

Off 4 - A ossada da garçonete só foi encontrada cinco meses depois do desaparecimento. Para a polícia a garçonete foi assassinada porque queria a separação do marido, que tinha outras mulheres e não trabalhava. Ana Paula era quem sustentava a casa. Aos 84 anos, dona Josefina quer agora criar a bisneta, que ficou sem a mãe assassinada e sem o pai, que agora está preso ${ }^{18}$.

O desenvolvimento de uma narrativa dramática e ao mesmo tempo emotiva, que busca a humanização do relato por meio do texto verbal, é

15 Marcelo Rezende. Programa Cidade Alerta, exibido em 19 mai. 2005. Matéria: Exame de DNA resolve crime.

16 Marcelo Rezende. Programa Cidade Alerta, exibido em 19 mai. 2005. Matéria: Exame de DNA resolve crime.

17 Programa Cidade Alerta, exibido em 19 mai. 2005. Matéria: Exame de DNA resolve crime.

18 Repórter. Programa Cidade Alerta, exibido em 19 mai. 2005. Matéria: Exame de DNA resolve crime. 
o que predomina no Cidade Alerta. Este apelo se confirma no comentário de Marcelo Rezende, após a exibição da matéria.

Comentário - Isso é que é a força de uma mulher. Na verdade a gente vê um sujeito preso, com uma cara de ironia, com direito de não falar nada. Enquanto isso essa senhora vai ficar, criou a filha, perde a filha, perde a filha e busca na netinha a força para continuar uma família. Isso é um exemplo que, infelizmente, temos tantos maus exemplos no país, isso é um bom exemplo ${ }^{19}$.

Além do texto verbal, dramático e apelativo, Marcelo Rezende novamente vai se valer da retórica e da performance cênica que o acompanham nos seus comentários.

Off 1 - Um pacto com o diabo, o sacrifício de uma mulher num ritual de magia negra, a vítima, Claudete Aparecida da Rosa, 43 anos, conhecida como Cláudia. Quem oferece a vida da doméstica como oferenda é a irmã mais velha dela, Rosa Bicudo, 53 anos $^{20}$.

Off 2 - Poucos passos separam Cláudia da morte. De um lado está Rosa, a sua irmã, do outro Ilda, uma das melhores amigas. Cláudia não imagina, mas a morte já está decretada. Quando chegar próximo ao rio será morta de maneira cruel. Sexta-feira 13, o dia escolhido por Rosa para matar a própria irmã. Cláudia que trabalha como empregada doméstica vai ser sacrificada num ritual de magia. Rosa, como gosta de ser chamada, e Ilda, a mulher que mexe com magia negra, vão ao encontro de Cláudia [...]. Elas amarram a vítima e começam a golpeá-la com um punhal. Cláudia recebe várias facadas no pescoço e nas costas. A doméstica não consegue se defender, depois de morta é jogada no rio. Rosa e Ilda jogam no rio o punhal que matou Cláudia $[\ldots]^{21}$.

19 Marcelo Resende. Programa Cidade Alerta, exibido em 19 mai. 2005.

20 Repórter: Vladimir Gama. Programa Cidade Alerta, exibido em 20 mai. 2005. Matéria: Vodu: irmã mata irmã.

21 Marcelo Resende. Programa Cidade Alerta, exibido em 20 mai. 2005. Matéria: Vodu: irmã mata irmã. 
É recorrente no programa a associação da prática de determinados crimes a eventos misteriosos, sobrenaturais, ou simplesmente a coisas "demoníacas". Esta relação proposta no enquadramento da notícia visa, também, associar a imag’em do "criminoso" a alg’o maligno, diabólico, como é o caso da matéria supracitada. Este tipo de associação se deve também ao próprio perfil editorial da emissora, visto que a Rede Record é de propriedade de um grupo evangélico neopentecostal, a Igreja Universal do Reino de Deus.

Segundo Belarmino Guimarães Costa (2002), a estética da barbárie, exteriorizada nas manchetes e nos títulos emblemáticos, na exclusão de temas socialmente necessários, na exploração do grotesco e do incomum, próprios da cobertura jornalística, difunde-se imperceptivelmente nas técnicas de produção da notícia, em sua conformação aos meios de comunicação e suas linguagens. O programa Cidade Alerta explicita isso em boa parte de suas notícias, ao selecionar os casos que ele considera mais dramáticos, os depoimentos mais marcantes, para mostrar à sua audiência.

Na edição do dia 30 de abril de 2005, Marcelo Rezende chama um VT em que aparece dentro do presídio para entrevistar, pela segunda vez, o homem que ficou famoso como "o maníaco do parque". Marcelo Rezende enfatiza o fato de estar mostrando a entrevista no telejornal Cidade Alerta, em primeira mão, após dois anos da prisão do maníaco, já que essa entrevista só seria exibida no domingo, no programa Domingo Espetacular, da emissora Record.

Marcelo Rezende afirma ter passado quatro horas com o detento, quando explorou todo o caso e pediu para que Francisco contasse como foi que ele matou, estuprou e violentou cada mulher. Como se não bastasse, Rezende diz ter ido à casa da senhora que está casada com o suposto maníaco do Parque. O apresentador chamou a entrevista com o "maníaco", finalizando o programa com a referida entrevista.

Cabeça da matéria - Chico Estrela agora é um homem casado, o Maníaco do Parque, põe a carinha desse maníaco aqui pra mim. Nós tivemos hoje, eu fui ao presídio, fiquei com Francisco de Assis Pereira por mais de quatro horas, e ficamos falando, ele reconta os 
crimes. Passado todo esse tempo, o que o Maníaco do Parque tem pra contar? Ele conta como matou cada mulher, hoje, distanciado do crime. E quem é a mulher dele? Você vai ver, uma mulher na altura mais ou menos de sessenta anos de idade, e ele disse assim pra mim: ela me dá tudo. E eu disse, como assim te dá tudo? Ele disse, ela me dá, tudo. Aí eu perguntei, mas ô maníaco deixa eu te dizer, eu não chamei de maníaco não, eu o chamei de Francisco. O que é que ela te dá tudo? Ele disse: material ou sentimental, o que é que você quer saber? Eu disse sentimental, aí ele contou uma história, e material? Ela me dá sabonete, me dá perfume, me dá tênis. E eu disse, como você matou e você seria capaz de matar de novo? Você vai ver a resposta do Maníaco do Parque, o que ele tem a dizer depois de seis anos de cadeia, eu vou para um rápido intervalo $[\ldots]^{22}$.

Este trecho é bastante ilustrativo para demonstrar a capacidade retórica de Marcelo Rezende. É por meio deste tipo de argumentação que o apresentador consegue ficar por muito tempo falando da mesma matéria durante o telejornal.

\section{CONSIDERAÇÕES FINAIS}

O programa temático Cidade Alerta pauta-se nas principais ocorrências do mundo do crime - acontecimentos violentos, grotescos ou esdrúxulos são mostrados diariamente no telejornal. Uma das principais estratégias de endereçamento do programa está no enquadramento dado às matérias, que procura mostrar os acontecimentos por um viés sensacionalista, por meio de cenas chocantes e com alto grau de apelo emocional. Seja por meio de imagens factuais ou por meio de reconstituição, o Cidade Alerta não hesita em mostrar corpos dilacerados por acidentes, perfurados por tiros, esfaqueados, ou entrevistas sensacionalistas com "criminosos".

Outro elemento central no endereçamento do Cidade Alerta é a cobertura dos fatos “ao vivo". Esta prática está intimamente ligada a dois fatores: primeiro as boas relações do programa com as polícias Civil e Militar que mantém a produção do programa sempre informada das ocorrências

22 Marcelo Resende. Programa Cidade Alerta, exibido em 30 abr. 2005. 
policiais; segundo, a capacidade e competência técnica do programa que está equipado com instrumentos capazes de levar informação "ao vivo" com o helicóptero Águia Dourada e as motolinks. Além disso, o formato de apresentação das notícias não segue um modelo padrão, mas, sim, um modelo narrativo com a utilização das transmissões "ao vivo" e contribui para a compreensão do endereçamento do programa. Parte do estilo do programa advém destas características, a exemplo do tom radiofônico, da liberdade verbal dos mediadores e da noção de um pacto de vigilância e de caça à criminalidade.

A performance cênica do mediador é outro elemento central de endereçamento do Cidade Alerta, juntamente com a articulação do texto verbal por meio do seu poder de retórica. Marcelo Rezende posiciona-se como um juiz que, ali mesmo, no tribunal midiático do Cidade Alerta, dá a sentença aos "criminosos". Como vimos, seus argumentos estão sempre atrelados a posições moralistas e conservadoras, como a defesa da pena de morte ou prisão perpétua para os transgressores da lei. Desta forma, o apresentador "juiz" deixa de ser um mero mediador para se tornar contraventor, pois, no momento em que defende e sugere punições que não estão previstas no Código Penal Brasileiro, ele também está sendo arbitrário e contraditório.

A noção de pacto sobre o papel do jornalismo é bastante requisitada pelo Cidade Alerta. O programa procura estabelecer um pacto com o telespectador de constante vigilância social, de jornalismo investigativo. A noção de prestação de serviço é pactuada na medida em que ele busca, teoricamente, defender os interesses dos cidadãos.

Outro elemento presente no programa é a noção de quarto poder, que fica mais evidente quando o mediador passa a questionar o papel dos poderes públicos. Em boa medida, este papel desempenhado pelo apresentador e repórteres estimula um ambiente social repressivo e autoritário, como ressalta Gerbner (2006), ao afirmar que a exposição excessiva da violência pela televisão cultiva nos receptores um exagerado senso de insegurança, de desconfiança social e de medo.

Portanto, as principais estratégias de endereçamento do Cidade Alerta estão na articulação da performance cênica dos mediadores, no formato 
de apresentação das notícias "ao vivo" e no pacto sobre o papel do jornalismo. Com a análise do telejornal Cidade Alerta procuramos demonstrar, por meio do uso do conceito de modo de endereçamento, articulado com o conceito de gênero televisivo e com a noção de promessa, como o programa se relaciona com a sua audiência, como ele inscreve as suas práticas comunicativas, especialmente, a partir da noção de pacto sobre o papel do jornalismo, e como o telejornal se posiciona mostrando as suas particularidades, definidas melhor como o seu tom ou estilo.

\section{REFERENNCIAS}

ALBUQUERQUE, Afonso de. Um outro quarto poder: imprensa e compromisso político no Brasil. Revista Fronteiras - Estudos Midiáticos, v.1. n. 1, p.07-37, dez. 1999.

BEK, Mine Gencel. Research note: tabloidization of news media: na Analysis of Television news in Turkey. European Journal of Communication, v. 19, n. 3, p. 371-386, 2004.

COBEN, David. Classical rhetoric and modern theories of discourse. In: WORTHINGTON, Ian (Org.). Persuasion: greek rhetoric in action. Routledge: London and New York, 1994. COSTA, Belarmino Guimarães. Estética da violência: jornalismo e produção de sentidos. Campinas, SP: Autores Associados; Piracicaba, SP: Editora UNIMEP, 2002.

FOUCAULT, Michel. Vigiar e punir: nascimento da prisão. Petrópolis: Vozes, 1987.

FRANCISCATO, Carlos Eduardo. A atualidade no jornalismo: bases para sua delimitação teórica. 2003. Tese (Doutorado Comunicação e Cultura Contemporâneas) - Faculdade de Comunicação, Universidade Federal da Bahia, Salvador.

GARCIA, Wilton. Corpo, mídia e representação: estudos contemporâneos. São Paulo: Pioneira Thomson Learning, 2005. GERBNER, George. Television violence and the art of asking the wrong question. Disponível em: <www.mediaed.org/videos/ 
CommercialismPoliticsAndMedia/ TheElectronicStoryTeller/ studyguide/html>. Acesso em: 20 nov. 2006.

GERBNER, George et al. Why so much violence? Disponível em: $<$ http://www.mediaed.org/videos/ CommercialismPoliticsAndMedia/TheElectronicStoryTeller/ studyguide/html>. Acesso em: 20 nov. 2006

GOMES, Itania Maria Mota et al. Brincadeira de bandido e mocinho: um exercício de análise do programa Cidade Alerta. Salvador: Programa de Pós-Graduação em Comunicação e Cultura Contemporâneas, 2003. Artigo desenvolvido na disciplina COM511 - Linguagens da Comunicação e da Cultura.

GOMES, Wilson da Silva. Jornalismo e esfera civil: o interesse público como princípio moral do jornalismo. In: PERUZZO, Célia M. K.; ALMEIDA, Fernando F. (Org.). Comunicação para a cidadania. São Paulo: Intercom; Salvador: UNEB, 2003. p.28-51. GUERRA, Josenildo Luiz. O percurso interpretativo na produção da notícia. 2004. Tese (Doutorado em Comunicação e Cultura Contemporâneas) - Faculdade de Comunicação, , Universidade Federal da Bahia, Salvador.

GUIMARÃES, Luciano. As cores na Mídia: a organização da corinformação no jornalismo. São Paulo: Annablume, 2003.

GUTTMAN, Juliana Freire. Jornal da MTV em três versões: gênero e modo de endereçamento como estratégia de mediação musical. 2005. Dissertação (Mestrado em Comunicação e Cultura Contemporâneas) - Faculdade de Comunicação, Universidade Federal da Bahia, Salvador.

JORON, Philippe. Fenomenologia da televivência. Revista Famecos, Porto Alegre, n. 25, 2004.

JOST, François. Introduction à l'Analyse de la télévison. París: Ellipses Marketing, 2004a. 
JOST, François. Seis lições sobre televisão. Porto Alegre: Sulina, 2004b.

MACHADO, Ida Lúcia. Análise discursiva de um gênero televisual: a entrevista no Talk show Jô Soares 11 e Meia. In: . O discurso da mídia. São Paulo: Oficina do Autor, 1996.

MARFUZ, Luiz César Alves. A curva e a pirâmide: a construção dramática e (tele)jornalística do acontecimento. 1996. Dissertação (Mestrado em Comunicação e Cultura Contemporâneas) Faculdade de Comunicação, Universidade Federal da Bahia, Salvador.

MENDONÇA, Kleber. A punição pela audiência: um estudo do Linha Direta. São Paulo: Quartet, 2002.

REZENDE, Guilherme Jorge. Telejornalismo no Brasil: um perfil editorial. São Paulo: Summus, 2000.

SOURIAU, Etienne. As duzentas mil situações dramáticas. São Paulo: Editora Ática, 1993.

SOUZA, Percival. Narcoditadura: o caso Tim Lopes, crime organizado e jornalismo investigativo no Brasil. São Paulo: Labortexto Editorial, 2002.

SPACENKOPF, Maria Izabel Oliveira. O olhar do poder: a montagem branca e a violência no espetáculo telejornal. Rio de Janeiro: Civilização Brasileira, 2003. VERÓN, Eliseo. Il est là, je le vois, il me parle. Revue Communications, Paris, n. 38, 1983. 


\title{
O modo de endereçamento do Globo Repórter
}

\author{
Marília Hughes Guerreiro Costa
}

\section{INTRODUÇÃO}

O Globo Repórter, depois do Jornal Nacional, é o mais antigo programa de telejornalismo da Rede Globo. A primeira exibição do Globo Repórter foi ao ar em abril de 1973 e, desde lá, o programa se mantém na grade de programação da emissora. São mais de 30 anos de Globo Repórter na televisão brasileira. Atualmente, o programa é exibido em horário nobre, numa frequência semanal, sempre às sextas-feiras, às 21hs 45min. (MEMÓRIA GLOBO, [2008]) A cada semana, o Globo Repórter aborda um tema diferente, que é desenvolvido em cinco blocos divididos por intervalos comerciais.

Velho conhecido da audiência, o Globo Repórter, de acordo com o site oficial do programa, é um dos produtos jornalísticos mais assistidos da televisão brasileira, com cerca de 30 milhões de telespectadores por programa. (MEMÓRIA GLOBO, [2008]) Segundo informações do IBOPE, o Globo Repórter, entre os programas jornalísticos da TV aberta, perde apenas para o Jornal Nacional, considerado o líder absoluto da audiência. Entre os dias 06 e 12 de agosto de 2007, por exemplo, o IBOPE registrou $32 \%$ de audiência para o Globo Repórter e $37 \%$ para o Jornal Nacional. Entre os dias 27 de agosto e 02 de setembro de 2007, o Globo Repórter alcançou $33 \%$ dos domicílios pesquisados e o Jornal Nacional se manteve com $37 \%{ }^{1}$. Ainda de acordo com o site oficial do programa (MEMÓRIA GLOBO, [2008]), o Globo Repórter foi feito para suprir uma carência do público por assuntos polêmicos ou de interesse geral, tratados em profundidade. Portanto, o programa promete jornalismo com profundidade. A proposta do presente artigo é analisar o modo de endereçamento do Globo Repórter, além de discutir a noção de profundidade colocada em prática no interior do programa.

1 Dados retirados do site <www.ibope.com.br> Acesso em: 21 dez. 2007. 


\section{GLOBO REPÓRTER: UM BREVE HISTÓRICO}

O Globo Repórter teve origem numa série de documentários feita para ser exibida na TV. A série estreou em 1971 e era chamada de Globo Shell Especial, em função do nome do patrocinador. Em 1973, a série torna-se um programa e recebe o nome de Globo Repórter.

Apesar do telejornalismo no Brasil ter, na sua origem, uma forte ligação com o rádio, não é essa a referência primeira do Globo Repórter, que apresentou, nos seus dez primeiros anos, um vínculo muito maior com o cinema. Nesse período, muitos cineastas colaboraram para o programa. A maioria deles vinha de uma experiência com o Cinema Novo e o Globo Repórter representou para eles um primeiro contato com a televisão. A presença de cineastas na equipe do Globo Repórter foi responsável por uma aproximação pioneira entre o cinema e a televisão no Brasil. Passaram pelo programa diretores como Eduardo Coutinho, Maurice Capovilla, Hermano Penna, João Batista de Andrade, entre outros. Muitos deles trabalharam no Globo Repórter através de uma produtora independente, a Blimp Filmes, responsável por realizar alguns documentários. Outros, como Eduardo Coutinho, eram contratados da própria emissora.

Apesar do preconceito que sofria a televisão por parte dos intelectuais de esquerda, principalmente em relação à TV Globo, símbolo da opressão na ditadura, os cineastas que se aventuraram no novo meio estavam motivados pela possibilidade de alcançar um número de espectadores impensável através do cinema, além de ter recursos para filmar com regularidade. Paulo Gil Soares, que dirigia a série Globo Shell Especial, declarou para o jornal O Globo, em três de julho de 1972 (SACRAMENTO, 2008): "Não estou interessado em fazer filme para meia dúzia de pessoas. Eu tenho a preocupação de informar e quero que minha informação chegue ao público. Para isso, uso a televisão".

No início, observa-se certa experimentação de linguagem, o que resulta em uma diversidade de abordagens de representação do "real". No entanto, havia algumas regras impostas pela emissora, e a principal delas era a presença de Sérgio Chapelin como o narrador oficial do programa. Segundo Hermano Penna (2002), em depoimento no site do É Tudo 
Verdade 2 , Festival Internacional de Documentários, “o que se conseguiu de expressão pessoal numa TV daquela, num momento como aquele, foi um milagre. Mas havia regras - e uma delas é que tinha que botar o Sérgio Chapelin. Como superar isto?"

Sérgio Chapelin foi uma presença marcante em quase todas as edições do Globo Repórter. Nos dez primeiros anos do programa, quando ainda não havia a presença de um apresentador em estúdio, cabia ao Sérgio Chapelin a narração. Em Mulheres do Cangaço (1976), dirigido por Hermano Penna, a voz over de Chapelin, que narra todo o programa, cede apenas à voz dos entrevistados. No entanto, a participação dele foi reduzida ou mesmo eliminada em alguns programas, uma vez que os diretores buscavam experimentar novas possibilidades de representação no documentário. O exemplo mais marcante é o de Teodorico, o Imperador do Sertão, realizado por Eduardo Coutinho em 1978. Neste programa, o diretor inova ao utilizar o protagonista como o narrador de sua própria história. Sobre o filme, em depoimento no site do É Tudo Verdade, Coutinho (2002) declara: "Meu sonho era realizar um filme sem locutor. O documentário começa com o Coronel dizendo: 'Estamos aqui fazendo um filme'. E ele vai narrando tudo, faz inclusive as entrevistas, 90\% delas."

O Globo Repórter foi lançado em plena ditadura militar. A presença de Sérgio Chapelin também foi a maneira encontrada pela Rede Globo de exercer controle sobre os conteúdos dos programas, no caso, o texto em over, já que o uso de película dificultava a revisão do material filmado pela emissora. Dez anos depois, em 1983, o suporte é mudado de filme para vídeo, o que altera o processo de trabalho e possibilita um maior controle, não apenas sobre os conteúdos, mas também sobre a forma. Nesse estágio, os repórteres ganham força, em detrimento dos cineastas. A Rede Globo passa a controlar inteiramente a produção do Globo Repórter, que fica, então, sob a responsabilidade de uma equipe interna de profissionais contratados pela emissora, em sua maioria, formada por

2 No ano de 2002, o Festival de Documentários É Tudo Verdade fez a retrospectiva Cinema na TV: Globo Shell Especial e Globo Repórter 1971-1979, com a presença de cineastas que trabalharam no programa na época. 
jornalistas. O ano de 1983, portanto, representa uma linha divisória que marca a transição pela qual passou o programa.

O Globo Repórter, numa perspectiva histórica, substituiu um modelo mais próximo do cinema e caminhou em direção à consolidação de um formato de documentário televisivo e jornalístico, que se tornou padrão na Rede Globo. Esse padrão, por sua vez, permite falar de um modo de tratamento dos temas, que independe do diretor ou mesmo do conteúdo do programa. O que é muito diferente dos produtos que marcaram os primeiros anos do Globo Repórter. A análise da trajetória do Globo Repórter nos permite compreender como a televisão brasileira, no caso específico, a Rede Globo, foi configurando um modo de fazer jornalismo na TV, cada vez mais distante de outros campos, como o cinema e o rádio, em direção a uma linguagem (ainda em formação) que fosse mais apropriada ao meio televisivo. Esse histórico do Globo Repórter reflete mudanças nos modos de endereçamento do programa, que, por sua vez, foram consolidando formas específicas do fazer jornalístico na televisão e moldando as expectativas dos telespectadores em relação ao programa.

\section{O GLOBO REPÓRTER HOJE}

Em 2008, o Globo Repórter completou 35 anos de exibição. Na edição de aniversário, exibida no dia 04 de abril, Sérgio Chapelin destaca a sua longa participação no programa:

Sérgio Chapelin - Boa noite! Estamos de volta às noites de sexta num dia muito especial para o nosso programa ${ }^{3}$. Em abril de 1973, o som agudo de uma guitarra elétrica anunciou pela primeira vez (no telão é exibida a vinheta de estréia do programa, em 1973). Globo Repórter, 35 anos no ar! Para celebrar o aniversário, o tema que você nos ajudou a escolher. Saúde e qualidade de vida. O assunto mais votado pelas milhares de pessoas que acessaram o nosso site. Quando apresentei o nosso programa pela primeira vez, não imaginava que passaríamos por mudanças tão radicais. E se nós

3 Durante os meses de janeiro, fevereiro e março de 2008, o Globo Repórter cedeu lugar à programação de férias da Rede Globo e foi substituído pela versão 8 do reality show, Big Brother Brasil. 
pudéssemos viajar no tempo, encontraríamos um Brasil muito diferente.

Sérgio Chapelin atua no Globo Repórter desde a estreia, o que nos permite dizer que ele confere um rosto ao programa. Inicialmente, sua função era apenas de narrador, na década de 80, ele se torna o primeiro apresentador do Globo Repórter, papel que exerce até os dias de hoje. Sérgio Chapelin começou a carreira como locutor de rádio, passando pela Rádio Nacional e pela Rádio Jornal do Brasil. Em 1972, estreou na Rede Globo como apresentador do Jornal Hoje, substituindo Ronaldo Rosas. No mesmo ano, passou a dividir com Cid Moreira a apresentação do Jornal Nacional, o noticiário de maior audiência no país. Juntos, eles formaram a dupla que por mais tempo esteve à frente de um telejornal. Sérgio Chapelin e Cid Moreira apresentaram o Jornal Nacional até 1996, quando houve uma reestruturação do noticiário e a dupla foi substituída por William Boner e Lília Witte Fibe. Com esse histórico, Sérgio Chapelin tornou-se um antigo conhecido da audiência e ganhou uma credibilidade que é transferida ao programa e reconhecida pelo público.

O Globo Repórter abre com uma vinheta de 10 segundos. A primeira imagem é da logomarca do programa, vista de longe, de forma tridimensional, apoiada sobre uma superfície curva, que simula um planeta. A cor segue uma gradação que vai do azul ao preto. Um deslocamento rápido nos leva para dentro da marca, percorremos o interior das letras, circulamos o globo posicionado no centro da figura. O globo se movimenta em torno de seu próprio eixo e numa direção ascendente. Ele é ao mesmo tempo o símbolo da emissora e parte do nome do programa. Após uma volta completa no globo, o movimento nos leva para o alto, onde podemos ler Globo Repórter. Toda a parte visual é acompanhada pela música-tema do programa, Freedom of Expression, que foi gravada originalmente pelo grupo J. B. Pickers. A música, que também é parte da trilha sonora do filme Vanishing Point (Corrida contra o Destino, 1971), se tornou uma marca do Globo Repórter. O som, agudo e de alto impacto, funciona como um sinal de alerta. Estratégia pertinente ao meio televisivo, cuja recepção, em geral, acontece no ambiente doméstico, marcadamen- 
te dispersivo. Através da vinheta, o programa fecha e inicia os blocos, anuncia o fim e o início dos intervalos comerciais. O programa é exibido há 35 anos e a concepção da vinheta (que é pensada a partir do nome do programa) e a música de abertura se mantiveram as mesmas, apesar de terem se modernizado a partir de avanços técnicos ao longo dos anos.

Logo após a vinheta, aparece Sérgio Chapelin em um plano médio, no estúdio do programa. Na parte inferior do quadro surge o nome do apresentador. O primeiro bloco é o maior de todos no que diz respeito ao tempo de apresentação de Sérgio Chapelin. Ele está vestido seriamente, com terno e gravata. Como um mestre de cerimônias, saúda o telespectador com um "Boa Noite" formal, que é acompanhado por um leve aceno de cabeça. Essa expressão é repetida em todas as aberturas do programa. Em seguida, ele informa o tema e seus desdobramentos, isto é, tudo aquilo que o público vai conhecer naquela noite. Ao final de cada bloco, Sérgio Chapelin faz uma chamada para o próximo, ou seja, ele reaparece brevemente para anunciar aquilo que o programa vai exibir "a seguir" ou "daqui a pouco", após o intervalo comercial.

Durante toda a apresentação do Globo Repórter, Sérgio Chapelin estabelece com o telespectador uma relação olho no olho. Em pé, no estúdio, ele fala de frente à câmera, portanto, para o público. Por vezes, ele aponta o dedo indicador em direção à audiência, como se dissesse "você que está me assistindo". Esse gesto cria uma aproximação ainda maior entre o apresentador e o telespectador. De modo análogo à fala, que é pausada, sóbria e sem mudanças bruscas de entonação, os gestos do apresentador são curtos e contidos. Apesar do estúdio do programa ser amplo, o apresentador se movimenta muito pouco pelo espaço. Todo o deslocamento de Sérgio Chapelin é ensaiado e controlado pelo posicionamento das câmeras. Muitas vezes, não é necessário nem que ele saia do lugar, basta uma virada de corpo e sua imagem passa a ser veiculada por outra câmera, com consequente mudança de enquadramento. Os movimentos também são planejados de acordo com o tamanho do quadro, num plano fechado, Sérgio Chapelin permanece parado, num plano mais aberto, podemos vê-lo avançar alguns passos em direção ao telespectador. Ele é sempre filmado 
de frente para a câmera, numa relação olho no olho com a audiência. A câmera também se movimenta, mas de modo suave e lento. A partir de um plano geral, a câmera avança em um travelling em direção ao apresentador. Esse movimento de câmera também é acompanhado por um deslocamento dele, que caminha alguns passos em direção à câmera. O conjunto dos movimentos, da câmera e do apresentador, cria o efeito de aproximação entre telespectador e programa. Com todas essas preocupações e marcações de cena, não há espaço para o improviso por parte de Sérgio Chapelin. As apresentações são sempre gravadas com antecedência e nunca há transmissão ao vivo, seja no estúdio ou na reportagem.

É através dos enquadramentos que o cenário é explorado visualmente. Através de um plano geral, vemos que no chão, no centro do estúdio, um círculo azul simula o globo terrestre. Azul é a cor do cenário do programa, também a cor usada na representação do planeta terra. A imagem do globo terrestre ganha tridimensionalidade a partir de uma parede côncava posicionada ao fundo. Essa parede possui linhas que simulam as marcações latitudinais e longitudinais da Terra. A partir delas formam-se telas onde são exibidas imagens do programa. A edição dessas imagens é feita a partir do texto verbal de Sérgio Chapelin e serve para ilustrar aquilo que o apresentador anuncia que iremos ver, naquela edição ou no próximo bloco. $\mathrm{Na}$ extremidade oposta à parede, há uma espécie de bancada, com uma forma convexa, que difere das tradicionalmente vistas em telejornais diários. Ela serve menos ao apresentador e mais à composição do cenário, pois sua presença reforça a ideia do globo terrestre. Na criação do cenário, percebe-se um minucioso trabalho de criação, assim como uma inegável complexidade tecnológica. Os recursos mobilizados dão importantes pistas do poderio da emissora, que investe na produção do programa e no telejornalismo. A impressão que temos do cenário, além da relação óbvia com o nome do programa, é a de que o apresentador está no centro do globo terrestre, no meio do mundo, que não há fronteiras para o Globo Repórter.

Para acessar os assuntos priorizados pelo Globo Repórter, que escolhe um único tema para a construção do programa como um todo, foi feito 
um levantamento de todas as edições exibidas entre janeiro e setembro de $2008^{4}$. Segundo o site oficial do programa (MEMÓRIA GLOBO, [2008]), os assuntos pertinentes ao Globo Repórter dividem-se em quatro categorias ou selos, que são estabelecidos a priori e definem a linha editorial do programa. São eles: aventura, comportamento, ciência e atualidades. Sobre a frequência, eles são abordados num esquema de rotatividade, com pequenas variações. A repetição de enfoques temáticos a cada mês é uma estratégia que, se, por um lado, influi na logística de produção, por outro, familiariza a audiência com o menu ofertado pelo programa. As escolhas temáticas do Globo Repórter também nos dizem sobre diferenças entre o programa e outros jornalísticos, como os telejornais diários, no que diz respeito à escolha da informação. O Globo Repórter, diferentemente dos noticiários, não está ligado ao factual do dia ou da semana. Não faz parte de sua promessa atualizar o telespectador com o quê de mais recente e relevante aconteceu no país e/ou no mundo, nem aprofundar notícias que receberam destaque em telejornais diários. Além disso, o Globo Repórter dedica-se a apenas um tema por edição, enquanto os noticiários são divididos em editoriais e abordam assuntos distintos. Algumas vezes, existem correspondências entre eles. É comum o Globo Repórter tratar de questões do dia a dia que estão em pauta na sociedade e que dizem respeito ao tempo presente do telespectador. É possível encontrar em matérias veiculadas em telejornais diários as mesmas categorias temáticas do Globo Repórter, como ciência e atualidades. Mas, qualquer que seja o tema da semana, no Globo Repórter ele é tratado ou como uma descoberta, uma grande novidade, ou como uma exclusividade do programa.

Sérgio Chapelin - "Uma nova descoberta médica: quem tem amigos corre menos risco de ficar doente" ${ }^{5}$.

4 Os temas que foram pautados pelo Globo Repórter nos últimos anos podem ser acessados através do site oficial do programa, onde estão listadas as edições do programa, por dia, mês e ano de exibição.

5 Globo Repórter, programa exibido em 19 de setembro de 2008. Selo Comportamento. 
Sérgio Chapelin - "O Globo Repórter revela com exclusividade o resultado assustador de uma pesquisa nacional: dois em cada três brasileiros têm problemas para dormir" .

Sérgio Chapelin - "Pela primeira vez, uma equipe de TV brasileira chega às pequenas aldeias das montanhas mais altas do planeta"7.

Sérgio Chapelin - "Quantas revelações! A ciência derrubou um mito que durou séculos. As células nervosas podem sim se regenerar" 8 .

A informação também é frequentemente oferecida como uma atração, como algo sensacional ou fora do comum. É comum o Globo Repórter prometer histórias e personagens que escapam ao ordinário.

Ségio Chapelin - "No programa dessa noite você vai conhecer o homem que sabe demais. O milagre da música! Como ela mudou a vida de uma diarista e de seus dois filhos".

A partir de expressões como essas, o programa busca despertar a curiosidade do público, atrair a sua atenção, que se vê diante de algo novo e inusitado.

Em programas classificados com o selo aventura, o telespectador é frequentemente convidado a conhecer um país estrangeiro, tratado como desconhecido por ele. Em 2008, foram exibidos os programas Japão: o país dos mistérios ${ }^{10}$, Os Mistérios da Turquia ${ }^{11}$, África: o berço da vida ${ }^{12}$, entre outros. Na abertura de cada um desses programas, Sérgio Chapelin promete ao telespectador uma viagem espetacular. No programa sobre a Turquia, por exemplo, o público é convidado a conhecer "as belezas e os mistérios da região em uma viagem fascinante". Já ao repórter

\footnotetext{
6 Globo Repórter, programa exibido em 22 de agosto de 2008. Selo Ciência.

7 Globo Repórter, programa exibido em 19 de setembro de 2008. Selo Aventura.

8 Globo Repórter, programa exibido em 26 de agosto de 2008. Selo Ciência.

9 Globo Repórter, programa exibido em 26 de agosto de 2008. Selo Ciência.

10 Globo Repórter, programa exibido em 13 de junho de 2008. Selo Aventura.

11 Globo Repórter, programa exibido em 11 de julho de 2008. Selo Aventura.

12 Globo Repórter, programa exibido em 1 de agosto de 2008. Selo Aventura.
} 
cabe nos guiar nessa viagem. O telespectador é tratado como um turista que comprou um pacote pronto. O programa define todas as atrações. Os lugares visitados, na maioria das vezes, são conhecidos pontos turísticos dos países, mas para torná-los mais atraentes e especiais aos olhos do telespectador, são tratados a partir de adjetivos como fascinante, surpreendente, incrível, entre outros. Estes são termos empregados pelos mediadores, apresentador e repórter, na atração/sedução do telespectador para que ele embarque nessa viagem através do programa. Como indica o selo, a narrativa é construída a partir de um forte diálogo com os relatos de aventura. Os recursos audiovisuais e retóricos, mais do que informar, buscam produzir efeitos sensoriais no telespectador. Nessas edições do programa, o objetivo é colocar o telespectador na situação, fazer com que ele se sinta capaz de compartilhar as sensações de quem está pessoalmente no local. No programa Mistérios da Turquia, um grupo de turistas passeia de balão pela Capadócia. O programa exibe imagens aéreas da região. Dessa forma, o telespectador tem acesso ao lugar como se estivesse ali, dentro do balão, voando com o grupo e compartilhando com ele o deslumbramento diante da paisagem exuberante do lugar. O repórter passeia pelas cidades subterrâneas da Turquia. Através de uma câmera subjetiva, o receptor fica colado à percepção do repórter. O clima é de suspense e mistério. A música também cumpre uma importante função nesse sentido. Além disso, há o texto verbal do mediador, ou seja, há todo um conjunto de aspectos audiovisuais utilizados a fim de se alcançar o resultado desejado. Esses recursos servem aos propósitos do programa, que além de seu caráter informativo, apela aos aspectos sensoriais do telespectador. Na maioria das vezes, edições desse tipo são produzidas por uma equipe de reportagem do Globo Repórter, mas o programa também pode veicular uma produção estrangeira, principalmente da BBC ou do Discovery Channel. Neste caso, cabe ao programa inserir a narração de Sérgio Chapelin e remontar o material para uma melhor adaptação ao formato desejado. Só em produções estrangeiras, o Sérgio Chapelin reaparece como narrador, função hoje exercida pelo repórter, mas que quase sempre coube ao Sérgio Chapelin nos programas dos anos 70 e início dos anos 80 . Sob o selo aventura também se encontram pro- 
gramas que abordam a natureza (o que inclui animais, vegetação, rios etc.) a partir de regiões brasileiras, como a Amazônia e o Pantanal, tratadas como exóticas e exuberantes. Nesses casos, a ênfase é colocada no perigo, nos desafios e obstáculos para se alcançar o objetivo desejado, filmar a onça-pintada, por exemplo. O repórter aparece como um aventureiro, um desbravador. O que foi observado no programa Diferentes Pantanais, descrito como "[...] uma aventura no território selvagem mais exuberante do Brasil"'13, e no programa Rainha das Matas Brasileiras, assim descrito: “[...] o Globo Repórter segue os passos da onça-pintada pelas mais belas florestas do país"14.

No Globo Repórter, grande valor é dado ao saber científico, que aparece numa relação estreita com qualidade de vida. A informação ganha os contornos de uma descoberta que trará consequências positivas à vida do telespectador. Com o selo ciência aparecem, principalmente, programas sobre saúde, um tema muito recorrente no Globo Repórter e assunto escolhido pelo público, através de votação pela internet, para celebrar os 35 anos do programa. No programa Novos Velhos, exibido no dia 27 de junho de 2008, o Globo Repórter estava preocupado em informar sobre as últimas descobertas para uma vida longa e saudável. No dia 10 de agosto de 2007, o Globo Repórter exibiu o programa Campeões da Nutrição e apresentou os alimentos mais saudáveis para os brasileiro através de uma lista exclusiva preparada pelas principais universidades do país. No Globo Repórter exibido no dia 23 de maio de 2008 sobre o humor, o sorriso é considerado um atestado de saúde. O exercício também é tratado como fundamental para uma vida saudável. No programa Mexa-se, do dia 18 de julho de 2008, o Globo Repórter buscou informar sobre o melhor exercício para quem não gosta de se mexer.

Em programas exibidos com o selo ciência, o Globo Repórter toma para si o lugar de mediar as informações entre os especialistas (fontes) e as pessoas comuns (leigas), como anuncia o apresentador no programa Novos Vethos, exibido no dia 27 de junho de 2008: "E o conselho dos especia-

13 Globo Repórter, programa exibido em 3 de agosto de 2007. Selo Aventura.

14 Globo Repórter, programa exibido em 2 de maio de 2008. Selo Aventura. 
listas: o que fazer para chegar bem à velhice?" Nessa edição, foi consultado Roberto Lourenço, professor de geriatria da Universidade Estadual do Rio de Janeiro (UERJ). Os especialistas, principalmente médicos e pesquisadores, detêm o saber e oferecem credibilidade à informação. No programa, cabe a eles apresentar soluções para problemas que afetam os brasileiros (a audiência). Em geral, elas vêm em forma de receitas: "no Globo Repórter de hoje receita de vida longa e saudável”. Portanto, para alcançar os resultados anunciados no programa, Vida longa e saudável, basta seguir passo a passo as instruções. Sobre as agruras da idade, o repórter informa: "o tempo passa para todos e provoca mudanças inevitáveis no nosso corpo. Dificuldade para ver e ouvir, perda de equilíbrio e força nos músculos, falta de atenção. E aí, um passo em falso pode ser um perigo." A partir da exposição do problema, o Globo Repórter aponta uma saída: a aula de prevenção de quedas, criada pela Universidade Federal Fluminense (UFF) e adotada pelo Programa Viva Idoso, da prefeitura de Niterói. Além da consulta a especialistas, o Globo Repórter usa dados oficiais e estatísticos para dar sustentação e relevância à informação. Segundo uma passagem do repórter, “[...] o Ministério da Saúde considera que as quedas e suas conseqüências já estão assumindo as dimensões de uma epidemia. Por ano, 93 mil idosos são internados no Brasil por causa de tombos". Entrevistas com idosos reforçam os dados estatísticos e humanizam a informação: "Eu caí umas sete vezes", nos conta a dona de casa Juraci Alice Lobo, de 71 anos. "Eu perdi o equilíbrio e fui de cara no chão. Abri a testa, o nariz todo, os dentes da frente e o joelho", revela a aposentada Maria Ercília Baronto Flores, de 85 anos.

As entrevistas com os idosos, logo após uma informação estatística fria, estão de acordo com uma tendência do telejornalismo praticado pelo programa de humanizar o relato através da construção de personagens, isto é, da apresentação de pessoas com nomes próprios e histórias de vida que servem para exemplificar a situação de muitas outras. No Globo Repórter sobre Novos Velhos, conhecemos a dona de casa Acyr Magalhães, de 84 anos. Ela é filmada andando pela cidade do Rio de Janeiro. Sua imagem é exibida com o seguinte off: 
Off - Ela vive do outro lado da Baía de Guanabara, no centro de Niterói, uma das cidades com o maior percentual de idosos do estado do Rio de Janeiro. Sofre as agruras que toda pessoa de idade enfrenta nas grandes cidades, como São Paulo ou Rio de Janeiro, em plena Praia de Copacabana.

Portanto, Dona Acyr Magalhães serve como exemplo de um grupo muito maior, os idosos que vivem em grandes cidades brasileiras. A humanização do relato provoca uma aproximação entre o programa e a audiência, mas essa aproximação, como sinaliza Gomes (2005), não significa simplesmente se reconhecer na tela, mas reconhecer aquela história que é contada como humana, verdadeira, real. Ao apresentar os personagens, o programa encena pequenos acontecimentos da vida cotidiana, outra forma de humanização do relato. Acyr é filmada caminhando pelas ruas da cidade. As pequenas encenações são bastante exploradas pelo Globo Repórter, que possui um tempo muito maior do que outros jornalísticos da emissora para abordar cada personagem e sua história.

Além dos especialistas, outra forma do Globo Repórter dar credibilidade à informação é dando destaque ao modo de produção da notícia a partir de palavras como o programa pesquisou, testou, provou, isto é, foi atrás e apurou a informação. No Globo Repórter sobre Crédito Fácil, por exemplo, após interpelar três vezes o público - "Vale a pena comprar a prazo? Fazer empréstimos no banco? Apelar para o famoso crédito?" - Sérgio Chapelin nos informa: "O Globo Repórter investiga os negócios à prestação". Também faz referência ao repórter, valorizando o trabalho desse profissional, que vai atrás da informação, que tanto investiga como testemunha os acontecimentos: "mas por que afinal as financeiras brigam tanto por um cliente? Nosso repórter entra na fila do dinheiro fácil e descobre o motivo." Outra forma encontrada pelo programa de enfatizar a verdade de uma informação é pela interpelação direta feita pelo apresentador em relação à audiência. No programa sobre os Mistérios do Cérebro, Sérgio Chapelin pede, logo no início da frase, que o público acredite no que vai ser dito em sequência. Ele diz: “Acredite... sol faz muito bem à nossa cabeça." Dessa forma, ele também magnifica a notícia, aumenta a sua im- 
portância, transforma uma informação banal, quase senso comum, em algo novo e surpreendente.

Com o selo comportamento, o Globo Repórter exibiu no dia 14 de dezembro de 2007 o programa Paixão, que se propôs a revelar "histórias inacreditáveis". No dia 25 de abril de 2008, foi exibido o programa Vida de Gari, que contou "histórias curiosas e emocionantes de brasileiros que cuidam da limpeza das grandes cidades". O programa do dia 09 de maio de 2008 falou das "Novas Famílias" a partir do modo "como pais e filhos se relacionam atualmente". Esses programas partem de histórias individuais para demonstrar tendências de comportamento e modos de vida do brasileiro nos dias de hoje. Com o selo atualidades, aparece uma maior diversidade de assuntos. É aqui que se encaixam as reportagens de serviço, como a exibida no dia 25 de julho de 2008 sobre Crédito Fácil. Nesses casos, o programa aconselha, orienta o telespectador/consumidor sobre o melhor modo de proceder numa determinada situação ou como evitar problemas futuros. No programa em questão, o Globo Repórter denunciou o mercado fácil de crediário, que fornece empréstimos a juros altíssimos, e alertou a população para negócios desse tipo. Ao mesmo tempo, com a ajuda de um especialista, um professor de economia da USP, ensinou o consumidor a calcular os juros de compras à prestação, escolher o melhor crediário, evitar dívidas e se livrar daquelas que já foram adquiridas.

Como o Globo Repórter é exibido em rede, o telespectador pretendido pelo programa encontra-se em qualquer parte do território nacional. Em qualquer edição do Globo Repórter, a fala dos mediadores é direcionada aos brasileiros. Dessa forma, o programa constrói entre as pessoas uma proximidade geográfica, uma identidade comum. Trata os telespectadores por aquilo que os une, a nacionalidade, e ignora as diferenças dos diversos estados e regiões brasileiras. Da mesma forma, aqueles que aparecem no programa são representações do povo brasileiro, o que fica evidente no texto de Sérgio Chapelin, logo na abertura do programa Educar para Mudar, exibido no dia 22 de julho de 2005.

Sérgio Chapelin - É preciso dar uma chance a milhões de brasi-

leirinhos que ainda trabalham na hora de brincar, como Matheus. 
Acredite, com cinco anos, ele quebra coco com porrete e machado para ajudar a família.

Outros exemplos apontam para essa preocupação do Globo Repórter de abranger o território nacional. No programa sobre os "Mistérios do Cérebro", exibido no dia 26 de agosto de 2006, falando da relação entre os alimentos e o funcionamento do cérebro, o repórter, em off, toma como exemplo o feijão e o arroz, nas suas palavras: "o prato típico do brasileiro."

Sérgio Chapelin - A ciência já estuda a relação entre os alimentos e o funcionamento do cérebro. Duas universidades gaúchas, a Federal e a Unisinos, estão pesquisando juntas quanto a nossa dieta pode oferecer nutrientes essenciais para melhorar a comunicação entre as células do cérebro. É o caso por exemplo do arroz com feijão, o prato típico do brasileiro, que ajuda a manter o cérebro funcionando bem.

Nos programas de viagem, o Globo Repórter fala do estrangeiro, preferencialmente, a partir de brasileiros que vivem ou passeiam por lá. Na edição sobre a Turquia, conhecemos Clara Süssekind, uma carioca de Copacabana, que é bailarina e vive há mais de um ano no país. Em lugares turísticos, como a casa de Maria, mãe de Jesus, o repórter Edney Silvestre entrevista duas brasileiras que estão a passeio na Turquia. Elas relatam a emoção que sentem ali. Ao final, despedem-se do repórter com um abraço caloroso. Além dos brasileiros que viajam como turistas, o repórter entrevista um casal formado por uma brasileira e um brasileiro descendente de turco, que vive há 24 anos no país. O programa, portanto, oferece diferentes exemplos de trajetórias de brasileiros na Turquia.

De modo a abarcar uma diversidade de telespectadores, o Globo Repórter optou por endereçar-se de maneira bastante didática. O Globo Repórter quer ser compreendido pelo público mais diverso, telespectadores com maior ou menor capacidade interpretativa e bagagem cultural. Por isso o programa investe no didatismo. As falas pausadas e bem articuladas do apresentador e do repórter demonstram cuidado com a clareza da informação, que deve ser acessível a todos, pessoas de diferen- 
tes níveis: social, econômico e cultural. Para isso, o programa também faz uso de recursos audiovisuais diversos, como gráficos, tabelas, trilha sonora, diagramações visuais, tudo isso para deixar os assuntos mais acessíveis aos telespectadores. O Globo Repórter que tratou de aspectos neurológicos (portanto, não visíveis a olho nu), recorreu à computação gráfica para facilitar a compreensão dos telespectadores em relação à anatomia do cérebro e de seu funcionamento. Na medida em que a voz off explicava o lugar responsável por determinadas emoções, essa parte do órgão era identificada por uma mudança de cor e por uma aproximação na imagem. Além disso, certas palavras-chave apareciam escritas na tela, à medida que eram ditas pelo narrador: "O cérebro tem menos de $5 \%$ da massa total do corpo" (aparece escrito na tela - menos de 5\% da massa total), "mas gasta mais de $20 \%$ de todo o oxigênio que a gente respira" (aparece escrito na tela - 20\% de oxigênio). "Com tanto oxigênio concentrado num espaço tão pequeno" (é dado um zoom na imagem do cérebro e aparecem vários símbolos de O2), "pode acontecer com o cérebro o que acontece com um pedaço de metal em contato com o ar, a oxidação" (aparece a palavra oxidação na tela), "é como se ele enferrujasse". Esse texto serve também para ilustrar o uso de analogias, tais como "pode acontecer com o cérebro o que acontece com um pedaço de metal”, a fim de facilitar a compreensão do que está sendo explicado, o que reforça o didatismo do programa.

Além disso, é comum o uso de perguntas como recurso didático. No programa do dia 25 de julho de 2008, sobre crédito fácil, Sérgio Chapelin faz as seguintes indagações: "Vale a pena comprar a prazo? Fazer empréstimos no banco? Apelar para o famoso crédito?” O apresentador, ao lançar perguntas ao telespectador, não espera que as respostas venham do público. O programa nem mesmo oferece meios para isso. As perguntas funcionam como estratégias retóricas que traduzem aquilo que o Globo Repórter acredita ser de interesse do telespectador, aquilo que o público quer saber. Ao formulá-las, o programa já possui as respostas. São as respostas que guiam a formulação das perguntas e não o contrário. Portanto, só valem perguntas para as quais as respostas estão prontas. É o programa, através de fontes autorizadas, que deve oferecer 
as respostas. As perguntas também indicam a direção (enquadramento) escolhida pelo programa ao abordar um assunto específico. Além disso, as perguntas não servem a um debate, crítica ou reflexão, mesmo quando os assuntos são polêmicos ou tratam de problemas crônicos da sociedade civil, como a questão educacional ou a questão ambiental. "Conhecemos uma escola sem paredes, alunos curiosos, professores dispostos a novas experiências. É uma receita tentadora. Como o ensino público pode ficar mais atraente"? Como resposta a essa pergunta, o programa nos oferece uma receita, ou seja, algo que pode ser seguido passo a passo pela audiência. Ou ainda: "A nossa equipe percorreu os lugares mais pobres do nosso país, como os jovens desses bairros encontram a profissão?” Aqui, já está dito que a equipe do programa percorreu esses bairros, portanto, encontrou a resposta para a pergunta proposta. Chapelin nos diz: "São Paulo. O que aconteceu no dia em que em uma hora, a chuva de um mês e meio despencou pela cidade?" Para essa pergunta já está preparada uma reportagem que acompanhou o tal dia de chuva. Nesses casos, as respostas simplificam questões complexas, que estão longe de serem aprofundadas no programa.

No Globo Repórter, a narração feita pelo repórter no interior da reportagem cumpre diversas funções. É através da voz em off que temos acesso às informações adicionais, complementares à fala dos especialistas, e que são validadas por eles, as fontes da informação. "Hoje, 80 milhões de brasileiros, quase metade da população do país, têm algum dívida”, nos informa o repórter Paulo Renato Soares. Também cabe ao narrador apresentar os personagens e fazer a costura de momentos distintos da reportagem, de ligar diferentes pessoas e lugares de modo a dar unidade ao programa e manter o seu foco temático. A passagem de um momento a outro da reportagem, isto é, de um desdobramento a outro do tema, também é feita pelos intervalos comerciais.

O programa trata as mais diferentes questões a partir de um enfoque positivo. Os exemplos escolhidos são de sucesso e superação. No programa sobre os Novos Velhos, o Globo Repórter construiu uma visão otimista da velhice. O programa utiliza diversos exemplos para defender a tese de que considerar idade sinônimo de limitação está ficando cada vez 
mais antigo, totalmente fora de moda. Portanto, os idosos apresentados no programa são ativos e dinâmicos. O clima é de alegria, os idosos fazem aulas de dança, são independentes, moram sozinhos. Há também histórias de maior apelo emocional, seja porque os idosos passaram pela superação de alguma doença ou por perdas afetivas. Nesses casos, o programa ressalta o apoio recebido por profissionais e principalmente pela família. O objetivo do programa é que essas histórias sirvam de exemplo para pessoas que vivem ou viveram situações semelhantes. Mostrar que, apesar de tudo, é possível ser feliz. Portanto, as dificuldades são mostradas como desafio e superação. No final, o que fica do Globo Repórter são mensagens positivas, de otimismo e esperança. No Globo Repórter sobre educação, por exemplo, o narrador, ao finalizar a reportagem sobre um menino que vive numa casa de adoção, nos diz a seguinte frase, em tom emotivo e nacionalista: "por destino ou por coincidência, nossas cores estão com ele, o menino que sente saudade. O calção verde, a blusa amarela e o céu azul e branco. Mas para a criança sempre há um toque de esperança, nas muitas cores do arco-íris" (congela a imagem do menino que brinca sozinho no parque da instituição, na sequência, surge no céu, por computação gráfica, a imagem de um arco-íris). Tudo isso é acompanhado por uma trilha musical melódica e sentimental, que continua enquanto surgem os créditos finais, de toda a equipe do Globo Repórter, sobre a imagem do garoto. Pode-se dizer que o programa se coloca como um lugar de soluções e de positividade para um telespectador que busca saídas para os seus problemas a partir de iniciativas individuais.

\section{CONCLUSÃO}

O Globo Repórter é um programa que trata os temas a partir de um mesmo formato, que se encaixa em qualquer assunto, apesar de algumas especificidades surgirem em função do enfoque temático. Sobre as regularidades, elas nos dizem do modo de endereçamento do programa, daquilo que lhe dá unidade e cria um modo específico deste se relacionar com a audiência. O Globo Repórter escolhe um tema por edição. É um programa que investe na credibilidade da informação, seja através da presença de especialistas ou do repórter, que é valorizado como testemu- 
nha do acontecimento. As pessoas comuns e suas histórias servem para ilustrar uma situação ou provar uma determinada tese. Ao disponibilizar a informação, o programa investe em diferentes recursos narrativos e de atração para chamar a atenção do telespectador. Portanto, a informação nunca é dada pura e simplesmente, mas ganha contornos de algo surpreendente, inédito, fascinante, espetacular. O programa faz uso de estratégias, formas e retóricas para provocar excitação, drama, espetáculo e fascínio, o que não é exclusividade do Globo Repórter. É comum nos dias de hoje que programas tradicionalmente destinados à informação utilizem estratégias narrativas mais associadas ao entretenimento. Por isso, a discussão sobre a relação entre a informação e o entretenimento está na ordem do dia nos debates acadêmicos, o que tem sido traduzido pela expressão infotainment. Há os que defendem e os que abominam essa aproximação. Mas, em qualquer caso, não há como negar essa dimensão do telejornalismo hoje, que nos diz do modo como o jornalismo de informação tem se desenvolvido na disputa pela audiência. E o Globo Repórter, como vimos, escapa e muito à dimensão meramente informativa. Nos dias de hoje, as pessoas têm fontes diversas para buscar a informação. O programa oferece algo a mais para seduzir a audiência. O Globo Repórter investe em elementos narrativos e de atração que acessam outras dimensões humanas, que não as cognitivas, apenas. Trata-se das dimensões afetivas, sensoriais e de prazer dos telespectadores. Mas isso não implica, necessariamente, num enfraquecimento da função informativa do programa. Aliás, uma forte preocupação do programa é em ser claro e acessível para qualquer um. Por isso, a opção do Globo Repórter é por um endereçamento didático. O programa formula perguntas para as quais as respostas já estão prontas. Para qualquer problema, o programa fornece soluções, ou melhor, receitas. Portanto, basta seguir as instruções. A postura de Sérgio Chapelin assemelha-se a de um consultor, que fala de maneira pausada a fim de ser compreendido por todos. Dessa forma, o Globo Repórter evita a reflexão, a discussão e o debate, mesmo quando se trata de problemas complexos e crônicos da sociedade. Assim, evita-se o conflito e opta-se pelo consenso. O telespectador não é convidado ao pensamento, ele é o receptor daquilo que o programa foi buscar e inves- 
tigar para ele e que é oferecido de forma mastigada, didática, mesmo que com uma roupagem narrativa ou espetacular. Essas estratégias revelam muito do modo como o Globo Repórter se relaciona com a sua audiência e como traduz a promessa de profundidade feita pelo programa.

\section{REFERENNCIAS}

COUTINHO, Eduardo. Retrospectiva brasileira: depoimentos. FESTIVAL INTERNACIONAL DE DOCUMENTÁRIOS “É TUDO VERDADE”, 7., 2002. Disponível em: <http://www. bdetudoverdade.com.br/2002/>. Acesso em: 07 jan. 2008. GOMES, Itania Maria Mota. Modo de endereçamento no telejornalismo do horário nobre brasileiro: o Jornal Nacional, da Rede Globo de Televisão, In: CONGRESSO BRASILEIRO DE CIÊNCIAS DA COMUNICAÇÃO - INTERCOM, 28., 2005, Rio de Janeiro. Congresso... Rio de Janeiro: [s.n.], 2005. Trabalho apresentado ao NP 07 - Comunicação Audiovisual.

LINS, Consuelo. O documentário de Eduardo Coutinho: televisão, cinema e vídeo. Rio de Janeiro: Jorge Zahar, 2004.

MATTOS, Carlos Alberto. Walter Lima Júnior: viver cinema. São Paulo: Casa da Palavra, 2002.

MATTOS, Sérgio. Um perfil da TV brasileira - 40 anos de história: 1950 -1990. Salvador: ABAP/A Tarde, 1990.

MEMÓRIA GLOBO. Globo Repórter. [2008]. Disponível em: <http://memoriaglobo.globo.com/Memoriaglobo/0,27723,G YN0-5273-238604,00.html>. Acesso em: 04 jun. 2009.

PENNA, Hermano. Retrospectiva brasileira: depoimentos. FESTIVAL INTERNACIONAL DE DOCUMENTÁRIOS “É TUDO VERDADE”, 7., 2002. Disponível em: <http://www. bdetudoverdade.com.br/2002/>. Acesso em: 07 jan. 2008. REDE GLOBO. Jornal Nacional: a notícia faz história. Rio de Janeiro: Jorge Zahar, 2004. 
SACRAMENTO, Igor. Depois da revolução, a televisão: cineastas de esquerda no jornalismo televisivo dos anos 1970. 2008. Dissertação (Mestrado em Comunicação) - Escola de Comunicação, Universidade federal do Rio de Janeiro, Rio de Janeiro. 



\section{Infotainment na TV: As estratégias de endereçamento do Profissão Repórter}

Thiago Emanoel Ferreira dos Santos

INTRODUÇÃO

O jornalismo é um campo em debate e os discursos em torno dele estão em disputa. Como todo campo social, ele apresenta embates entre os seus agentes. De um lado, estão aqueles que defendem um modelo de jornalismo que pode ser aplicado em diferentes contextos sociais, culturais e econômicos e, do outro, aqueles que acreditam existir tantos jornalismos quanto são estes contextos. Os primeiros, acadêmicos vinculados à teoria crítica e à tradição que estuda as relações existentes entre a comunicação e a política, veem com apreensão a relação do jornalismo com outras áreas, como o entretenimento. Os outros, alguns vinculados aos estudos culturais, propõem que esta articulação entre informação e entretenimento não seja vista necessariamente como um problema ou distorção para nenhuma das duas áreas.

A articulação existente entre o campo da informação e a área do entretenimento no telejornalismo brasileiro já foi objeto de análise em outros artigos formulados por mim. O primeiro foi resultado da disciplina Comunicação e Cultura Contemporâneas, em que, em grupo, analisei como os dois campos se articulavam no interior do programa Custe o Que Custar (CQC) da Rede Bandeirantes. Na análise do mesmo programa, escrevi em conjunto com a doutora Itania Maria Mota Gomes e a mestre em Comunicação Juliana Gutmann, o artigo Eles estão à solta, mas nós estamos correndo atrás. Jornalismo e Entretenimento no Custe o que Custar (2008), publicado na revista eletrônica E-Compós. A observação deste programa, nas duas oportunidades anteriormente citadas, mostrou ser possível a articulação entre a informação e o entretenimento em programas televisivos, sem acarretar em um problema nem na sua função de informar, nem na de entreter. 
Este presente artigo retoma a discussão sobre a relação destes dois elementos, mas agora, no interior de outro programa: o Profissão Repórter da Rede Globo. Este produto televisivo já foi analisado por mim em minha monografia ${ }^{1}$ Para este fim, utilizo como metodologia de análise os operadores formulados por Itania Maria Mota Gomes (2007) - mediador, contexto comunicativo, organização temática e pacto sobre o papel do jornalismo, articulando-os ao conceito de trajetória formulado pelo sociólogo Pierre Bourdieu (1997), em que ele diz que a trajetória dos agentes de determinados campos ajudam a analisar a atuação destes agentes. Utilizo este conceito articulado ao de mediador, formulado por Itania Gomes (2007), para pensar como a atuação dos mediadores do Profissão Repórter à frente do programa está vinculada à trajetória profissional deles. Neste artigo, articulo ainda aos operadores os três modos de comunicação propostos por Mats Ekström (2000), em que ele afirma que o telejornalismo contemporâneo se comunica através de três modos possíveis, sem que haja exclusividade de apenas um deles, mas que, no endereçamento dos programas, um destes se sobressai. Os três modos são informação, storytelling e de atrações.

Ekström (2000) afirma que no modo de comunicação de informação, a intenção da produção é oferecer informação que pareça ser suficientemente relevante, suficientemente interessante e suficientemente necessária para apreender a possível audiência. No modo de comunicação storytelling, os produtores almejam contar uma história que seja excitante ou suficientemente dramática para apreender os possíveis telespectadores. Já no modo de comunicação de atrações, a produção quer oferecer atrações que sejam espetaculares, chocantes ou extraordinárias para fascinar aqueles que estejam assistindo a um dado programa.

\section{PROFISSÃO REPÓRTER}

A primeira edição do programa Profissão Repórter da Rede Globo foi ao ar no dia 29 de maio de 2008, com a decisão da rede de televisão em constituir uma terceira linha de atrações noturnas, como é chamada

1 Infotainment e telejornalismo: as estratégias de endereçamento do Profissão Repórter. Ver SANTOS, 2009. 
a faixa de programação das 23 horas. Na descrição do programa no site Memória Globo da Rede Globo, a concepção do mesmo é atribuída ao jornalista Caco Barcellos, que também é apresentador, repórter e editor do Profissão Repórter. Na terça-feira, vai ao ar logo após o programa humorístico Toma Lá Dá Cá e antes do Jornal da Globo, aproximadamente às 23 horas e 15 minutos. O programa é dividido em dois blocos, totalizando aproximadamente 25 minutos, tendo a primeira parte da atração, em média, 18 minutos e a segunda, sete minutos. O Profissão Repórter é líder no horário, atingindo uma média de 21 pontos, considerado por jornalistas especializados em televisão, como a colunista do jornal o Globo Patrícia Kogut, um bom número para a sua hora de exibição. Nesta faixa de horário, a principal concorrência vem da Rede Record que leva ao ar uma telenovela e os reality shows - nos períodos analisados, estava no ar o reality $O$ Aprendiz.

O programa surgiu como um especial do Globo Repórter, em abril de 2006, depois, ainda no mesmo ano, começou a ser exibido como um quadro do Fantástico. Da data de estreia até o lançamento na grade semanal da Rede Globo foram 48 reportagens no Fantástico e cinco especiais na programação da Globo. O primeiro especial de fim de ano, chamado Vida do mar, foi exibido em 14 de dezembro de 2006 e abordou as aventuras dos trabalhadores do mar nas plataformas de petróleo e submarinos da Marinha. Os outros especiais foram O Brasil sobre duas rodas, exibido no dia 30 de agosto de 2007; O Brasil da hora-extra, que foi ao ar no dia 18 de outubro daquele mesmo ano; e Em busca do sucesso, apresentado no dia 13 de dezembro, também em 2007.

O primeiro programa ocupando o atual espaço na grade da Rede Globo teve como tema o transplante de órgãos. Neste artigo, foram analisados os dez últimos programas de 2008, da edição do dia 14 de outubro, cujo tema foi o Círio de Nazaré, até o dia 16 de dezembro, em que as equipes de reportagem retornaram ao Estado de Santa Catarina que havia sido devastado por enchentes duas semanas antes. Foram analisadas ainda dez

2 O programa Toma Lá Dá Cá saiu da grade da Rede Globo em 2009, após o período analisado no presente artigo. 
edições exibidas em 2009, do dia 14 de abril, cujo tema foi transtornos alimentares, até o dia 15 de junho, em que foi realizada uma reportagem sobre o primeiro ano da lei seca.

\section{O CONTEXTO DO PROGRAMA NA TV GLOBO}

Achamos necessário, para falar da articulação sobre a informação e o entretenimento no programa Profissão Repórter, fazer uma breve retomada da relação da Rede Globo com as áreas da informação e do entretenimento e destacar os dois programas que, na nossa visão, têm articulado estes dois campos em seu interior, há alguns anos, e com os quais o programa analisado neste artigo tem maior vinculação. Falamos aqui do Globo Repórter e do Fantástico.

O Fantástico é visto pela Rede Globo como um "espaço para a experimentação de novas ideias e formatos”. (MEMÓRIA GLOBO, [2008]) A primeira edição do programa foi ao ar no dia 5 de agosto de 1973, apresentado pelo jornalista Sérgio Chapelin. Já na primeira edição, tanto o campo da informação quanto o do entretenimento estavam inseridos, com reportagens, quadros de dança e uma apresentação das notícias da semana feita por Chapelin. José Itamar de Freitas, diretor-geral do programa, a partir de 1977, definia as reportagens que eram apresentadas no Fantástico como "um meio-termo entre o Globo Repórter e os telejornais diários”. (MEMÓRIA GLOBO, [2008])

Em 2006, este "espaço de experimentação" começou a exibir como um dos seus quadros o Profissão Repórter. No programa, as reportagens duravam 12 minutos e, além disto, mostrava-se o processo de produção da matéria que estava sendo transmitida. O uso de recursos gráficos, atrelados ao elemento entretenimento da TV, que, historicamente marcou o programa dominical, foi também apropriado pelo quadro que havia surgido em abril daquele mesmo ano no Globo Repórter.

O Globo Repórter é um dos programas jornalísticos de vida mais longa na história da televisão brasileira. Ele estreou em abril de 1973, mesmo ano que o dominical Fantástico. O programa foi criado para ser uma versão da Rede Globo do 60 minutes da rede americana CBS, mas limitações do corpo técnico fizeram a direção da rede mudar de ideia. Tendo como 
referência o programa Globo Shell Especial, a direção da Globo, naquela época, decidiu adotar narrativas conduzidas a partir das imagens, dos depoimentos dos entrevistados e da esporádica locução em off do apresentador. O repórter não aparecia no vídeo.

A mestre em Comunicação Marília Hughes (2009) apresentou em sua dissertação de mestrado o modo de endereçamento do Globo Repórter, em que ela identificou três modos de endereçamento em três períodos distintos do programa. No primeiro período, citado no parágrafo anterior, documentaristas dirigiam o programa. No segundo período, identificado por Hughes (2009) como um período de transição, situado entre os anos de 1983 e 1984, assumiu a direção do programa Robert Feith. Houve uma substituição dos documentaristas por jornalistas, mas a direção manteve como ponto fundamental a manutenção do entretenimento na produção das reportagens. O Globo Repórter passa a querer emocionar, sem perder a função de informar.

No terceiro período, Hughes (2009) agrupou as edições mais recentes do programa, mais especificamente, aquelas exibidas em 2008. O Globo Repórter, desde 1995, passou a apresentar apenas um tema por edição. Os temas foram classificados, pela mestre em comunicação, em quatro categorias, sendo elas ciência, atualidade, aventura e comportamento. Segundo Hughes (2009), os selos estão indicados no site do Globo Repórter, mas não aparecem durante a sua exibição na TV. Hughes afirma que o Globo Repórter, diferentemente dos outros telejornais, não se preocupa com o factual.

Do ponto de vista do formato, o Profissão Repórter, dentro da grade da Rede Globo, aproxima-se mais do Globo Repórter. Ambos não possuem bancadas e apresentam, semanalmente, um tema em cada edição e, além disto, não fazem cobertura das notícias classificadas como hard news. Do Fantástico, acredito ter ficado no programa a aposta de articular, de forma evidente, a informação com o entretenimento.

Neste artigo, utilizamos o conceito de entretenimento, apresentado por Itania Gomes em seu artigo O embaralhamento de fronteiras entre informação e entretenimento e a consideração do jornalismo como processo cultural e histórico, compreendendo-o como um valor social contemporâ- 
neo, organizado como indústria e que se vale de determinadas estratégias de atração.

\section{BASTIDORES DA NOTÍCIA E O TELEJORNALISMO DE ATRAÇÕES}

Iniciamos a análise problematizando as reiteradas afirmações por parte dos produtores do programa, através de entrevistas e na definição do programa na internet, de que se trata de um programa jornalístico que apresenta os bastidores da notícia. Esta condição do programa é reforçada não apenas pelos discursos utilizados por quem faz o Profissão Repórter, mas também, através de recursos imagéticos como os dispostos na vinheta de abertura.

A vinheta é constituída por imagens da ilha de edição, pessoas na redação, pessoas digitando em computadores, ao mesmo tempo em que aparecem caracteres na tela como se fossem resultado destas digitações, aparece um cinegrafista com uma câmera na mão, telas de computadores com softwares de edição abertos, sucedidos por um símbolo da Globo em um carro de reportagem e terminando com o nome "Profissão Repórter", na cor amarela, e um microfone com o símbolo da Globo atrás, além disto, uma mão no teclado e no mouse. Todas estas imagens citadas anteriormente vão se sucedendo e sendo mostradas com efeitos de edição, com cor azul, e reproduzindo o enquadramento visual da lente da câmera. A música de abertura e esta sucessão de imagens se articulam em uma vinheta de abertura que se assemelha a um pequeno videoclipe, mostrando mais uma vez a relação do programa com recursos audiovisuais típicos do entretenimento, mostrando e informando sobre etapas do processo de construção de uma reportagem.

Outra ação que reforça esta ideia do programa em mostrar a atividade dos jornalistas durante a produção da notícia é a afirmação feita pelo apresentador Caco Barcellos, após apresentar as frentes de reportagem que compõem o programa do dia. "Os bastidores da notícia. Os desafios da reportagem", afirma Barcellos, antes da sucessão de imagens citada acima, indicando que estes são os objetivos do programa. Utilizar este discurso serve ainda para que seja atribuída uma noção de veracidade sobre aquilo que está sendo dito, através da construção da credibilida- 
de, que vai sendo construída pelo programa em relação à audiência, ao permitir que ela acompanhe o processo de produção da notícia. Mostrar os bastidores, mais a presença de Caco Barcellos, como será dito mais detalhadamente no tópico a seguir, são elementos-chave para o entendimento do modo de endereçamento do programa.

Ainda em relação aos bastidores, duas estratégias foram anunciadas por Caco Barcellos durante o programa Vídeo Show, exibido às tardes na Globo, para o ano de 2009. Na edição do dia 14 de abril do programa vespertino, que mostra os bastidores da produção televisiva da Rede Globo, Barcellos anunciou o que ele chamou de "duas grandes novidades": a nova redação e um processo seletivo para a escolha do novo repórter integrante do programa. Sobre a redação, disse Barcellos:

A temporada 2009 do Profissão Repórter começa com uma novidade que eu mostro pra vocês agora. A nossa nova redação: a redação- estúdio. Daqui, a gente vai gravar os bastidores do nosso trabalho, principalmente, o trabalho da edição das matérias. A redação não está completamente cheia, porque aqui, a gente segue a regra básica de reportagem: lugar de repórter é na rua ${ }^{3}$.

Precisamos fazer duas considerações em torno do discurso adotado pelo principal mediador do Profissão Repórter. A primeira consideração sobre a redação estar vazia, porque lugar de repórter é na rua, mostra que o programa quer se endereçar ao telespectador como realizador de um jornalismo que apura as informações que ali estão sendo mostradas, conferindo autenticidade ao papel desempenhado pelos jornalistas. A outra consideração é sobre a novidade anunciada por Barcellos em relação à redação-estúdio. Este ambiente foi realmente incorporado aos programas exibidos em 2009. A audiência pôde assistir trechos de discussão da edição do programa em seis edições das dez que compõem o corpus de análise do programa no ano anteriormente citado. Em uma destas seis, na intitulada Riscos da Vaidade, exibida no dia 02 de junho de 2009, pudemos ver Caco Barcellos discutindo com os repórteres Gabriela Lian e Felipe Gutierrez a exibição de imagens de uma vítima de cirurgia malsucedida.

\footnotetext{
3 Entrevista ao programa Video Show.
} 
Na discussão, podemos ver algumas indicações sobre o pacto construído pelo programa em relação ao jornalismo. Mesmo com o trauma causado a uma das personagens pela exibição recorrente da imagem de sua cicatriz ocasionada por um erro médico, Caco Barcellos vota por, mais uma vez, mostrá-la, defendendo a necessidade de exibir a imagem, sabendo a comoção que ela pode causar. Barcellos aposta na estratégia defendida por Ekström (2000), como telejornalismo de atrações, em que algo que desvia da normalidade é mostrado por um programa a fim de causar o choque a quem assiste. A intenção de Barcellos e do Profissão Repórter, neste momento, foi, além de informar, chocar, mostrando consequências físicas de uma cirurgia plástica malsucedida. Esta informação foi reforçada no decorrer do programa, utilizando uma fonte especializada, o psiquiatra Taki Cordas, que falou das consequências psicológicas dos transtornos alimentares. Ao utilizar o modo de comunicação de informação através de Cordas, o programa relaciona-se com os valores jornalísticos: interesse público, relevância e responsabilidade social, ao problematizar as histórias que estão ali sendo apresentadas. No corpus observado, compõem o rol de fontes especializadas e/ ou oficiais ouvidas durante o programa: delegados, promotores, médicos e bombeiros.

\section{STORYTELLING DO PROFISSÃO REPÓRTER}

$\mathrm{Na}$ abertura de todas as edições do programa, o Profissão Repórter já mostra várias das estratégias do storytelling utilizadas por ele. Através de uma narrativa, mostrando mais um elo de ligação com o entretenimento, ele apresenta os personagens, e introduz partes das histórias daqueles personagens. O texto é acompanhado por determinados enquadramentos de câmera que ressaltam a emoção dos personagens. O programa foi iniciado desta maneira em todas as edições que integraram o corpus de análise e não é o único momento que esta estratégia é empregada. Em seu interior, os repórteres adotam esta mesma estratégia ao contar as histórias das pessoas ali envolvidas nas frentes de reportagem e eles mesmos são colocados na posição de personagens, seja pelos discursos utilizados por Caco Barcellos, seja por situações em que eles mesmos contam o que aconteceu com eles no decorrer da produção da matéria. 
Outra estratégia que pode ser depreendida do trecho que relata a entrevista de Caco Barcellos ao Vídeo Show é a serialização, exibida quando Barcellos trata da temporada 2009. Este é um recurso discursivo mais comum a programas vinculados ao entretenimento e aqui é empregado na identificação de um programa jornalístico. Além disto, todas as edições foram disponibilizadas na internet com um nome - a edição citada no trecho acima foi intitulada Desafios da Balança - como se fosse o título daquela história, reforçando se tratar de um programa que emprega estratégias oriundas das narrativas ficcionais.

Sobre a abertura do programa, é necessário dizer que, em todas as edições, quem apresenta os repórteres é Caco Barcellos. Ele é o único jornalista cuja apresentação é feita através de legenda. Em todas as edições analisadas, é empregada a mesma estratégia de edição em que Barcellos fala o nome dos repórteres, estes aparecerem destacados através do recurso visual de deixar a imagem nas cores azul e laranja e logo depois mostrar a primeira parte da reportagem deles - ou mesmo sem aparecem, como no caso acima, surgem através da voz off.

Através da utilização deste recurso, Barcellos assume, no esquema narrativo, o papel do narrador onisciente, sabe o que vai ser mostrado, apesar de não estar naquela cena. Os outros repórteres são os narradores-personagem. Incluem-se nas histórias, choram, se emocionam. Mostrar os bastidores, na retórica do programa, serve para mostrar o desenvolvimento das histórias, colocando os jornalistas como personagens delas. O programa aproxima o jornalismo da sensibilidade, alterando a imagem defendida por certa tradição teórica que pensa que o jornalista tem que ser observador imparcial da realidade. É uma mudança na concepção do que é jornalismo, aproximando-se muito mais à concepção defendida por autores dos estudos culturais.

Em relação às características utilizadas pelo Profissão Repórter, que se referem ao modo de comunicação storytelling, achamos essencial abordar mais uma, encontrada na edição do programa exibido no dia 02 de junho de 2009, em que o título foi Riscos da Vaidade. Nesta edição, vemos o Profissão Repórter colocando um dos personagens envolvidos na reportagem no papel de vilão e acompanhamos a reconstrução da histó- 
ria tendo como objetivo manter o suspense para apresentar o desfecho da história e apresentando o momento do clímax. Uma das frentes de reportagem, sob a responsabilidade de Gabriela Lian e Felipe Gutierrez, citada no início deste tópico, ficou responsável por acompanhar as histórias das vítimas do médico Marcelo Caron, ex-médico cirurgião, acusado de falsificar o diploma desta especialidade e julgado pela mutilação e morte de diversas mulheres.

O programa enquadrou Marcelo Caron como vilão, perseguiu-o, e justificou a ida a outro Estado, diferente daquele em que a reportagem estava sendo feita, pela necessidade de ouvir os dois lados. Desta maneira, o Profissão Repórter quis passar a sensação de imparcialidade para o telespectador, ao mesmo tempo em que exibe as reações e respostas de Caron, reforçando a posição do médico naquela narrativa. No entanto, quando Caco Barcellos pergunta à repórter se foi emocionante, ele expõe a estratégia do programa de querer colocar na tela a emoção causada pelo confronto entre os dois. A última fala de Barcellos, apresentada no fim do programa - em que ele reiterou as condenações de Caron -, reforça esta disposição do programa de colocar o médico como culpado.

Nesta edição, pode-se perceber ainda a importância que o jornalista Caco Barcellos recebe no endereçamento do programa. Além de todas as funções já elencadas neste artigo, podemos observar nesta perseguição realizada pela repórter Gabriela Lian uma influência da trajetória profissional de Barcellos no jornalismo investigativo. A todo o momento, ela utiliza elementos deste tipo de jornalismo para configurar a reportagem: foi atrás do endereço do médico no tribunal de Goiânia, depois foi até o condomínio do médico e só encerrou a sua busca após encontrá-lo. A própria terminologia frente de reportagem utilizada pelo programa e adotada por este artigo retrata a ideia da busca incessante pela apuração da reportagem típica do jornalismo investigativo.

\section{CACO BARCELLOS E AS DIVERSAS POSIÇÕES NO}

PROFISSÃO REPÓRTER

Como temos demonstrado nesta análise, o jornalista Caco Barcellos assume diversas posições no interior do Profissão Repórter. Ele foi o criador 
do programa, é editor, aquele a quem, por diversas vezes, os outros repórteres recorrem no desenvolvimento das reportagens, é apresentador, assumindo nesta condição uma posição de narrador onisciente e chefe, como no trecho em que retratamos a perseguição ao médico Marcelo Caron. Estas diversas posições de Caco Barcellos no interior do programa devem-se, em boa medida, à sua trajetória dentro do campo jornalístico. Barcellos possui reconhecimento dentro do campo e notoriedade perante o público e outros campos.

Uma mostra desta notoriedade, pelo menos em relação à audiência do programa, foi exposta na edição do dia 04 de novembro de 2008, em que eles abordaram a Vida no Porto. Um motorista de caminhão que estava descarregando no porto falou para Caco Barcellos que gosta dele e que assiste ao programa, numa clara estratégia do programa de também mostrar que tem reconhecimento por parte de quem o assiste. A possibilidade de mostrar este telespectador do programa somente foi possível em um programa que afirma mostrar os bastidores, não sendo possível em outro programa que faça um jornalismo tradicional.

Além das estratégias explícitas no programa, como esta, a própria aposta do Profissão Repórter em edições como a do médico Caron mostra uma influência da trajetória do jornalista no perfil do programa. Barcellos é reconhecido como um jornalista que faz boas reportagens investigativas. Ele começou a se destacar realizando reportagens com temáticas relacionadas à violação dos Direitos Humanos na Ditadura Militar. No ano de 1995, o Globo Repórter exibiu uma reportagem em que Caco Barcellos identificou, num cemitério clandestino em São Paulo, os corpos de oito vítimas do regime militar, que haviam sido consideradas "desaparecidas". A reportagem foi feita pelo jornalista dois anos antes junto com o editor Ernesto Rodrigues. A matéria ganhou um prêmio relacionado à defesa dos Direitos Humanos.

Ainda durante a sua passagem pelo Globo Repórter, Barcellos recebeu o prêmio Vladmir Herzog, oferecido pelo Sindicato dos Jornalistas de São Paulo, por uma reportagem exibida ainda durante a sua passagem pelo Globo Repórter. Na matéria, Barcellos investigou o atentado ao Riocentro, ocorrido em 1981. Ouviu mais de 50 pessoas, inclusive testemunhas 
ignoradas pelas autoridades militares. Em 2001, mais um prêmio, agora o Líbero Badaró, promovido pela Revista Imprensa, pela série de reportagens sobre a guerra civil angolana exibida no Fantástico.

Além destas duas reportagens, Barcellos foi autor de dois livros ainda na linha de reportagem investigativa, o primeiro foi Rota 66, em que ele investigou, durante cinco anos, o esquadrão da morte que age na cidade de São Paulo. Ele mostra como é o sistema de extermínio e seus métodos de atuação e como o sistema incentiva esse tipo de ação. O outro foi o livro-reportagem Abusado, em que ele conta a vida de um traficante do Morro Dona Marta no Rio de Janeiro e fala sobre o tráfico de drogas nos morros cariocas. Cada livro rendeu a Barcellos um prêmio Jabuti, a principal premiação de literatura do Brasil. O segundo livro deu mais um prêmio Vladmir Herzog de Anistia e Direitos Humanos a Barcellos.

Estas premiações, principalmente os dois Vladmir Herzog, concedidos pelo Sindicato de Jornalistas de São Paulo, demonstram o reconhecimento que Barcellos tem no interior do campo jornalístico, colocando- o como um agente importante no meio jornalístico e também no meio televisivo. Já o prêmio Jabuti concedido na categoria de não-reportagem denotam a notoriedade do jornalista citado. Barcellos é "a cara" do programa, ou seja, é o principal mediador daquele programa, assumindo as diversas posições citadas anteriormente.

Ainda sobre Barcellos, temos que afirmar que ele é o único mediador do programa que se direciona olhando diretamente para a câmera, como se estivesse, ao olhar para ela, estabelecendo um diálogo com os telespectadores. Os outros repórteres colocam a audiência como testemunha da ação. Ela está sempre acompanhando as suas ações ou dúvidas em relação ao processo de produção das reportagens; as passagens são feitas, na maioria das vezes, em movimento, reforçando esta condição dada à audiência de observadores da construção da reportagem.

Podemos já dizer, após retratar aqui a trajetória do jornalista Caco Barcellos e como ela é articulada pelo programa, que o endereçamento do programa como um local onde serão mostrados os bastidores da notícia se dá através da convocação desta trajetória e da posição conferida a ele no Profissão Repórter. No entanto, este lugar de Caco Barcellos à frente 
do programa e na construção do endereçamento não estaria completo se não fosse a contraposição que ele recebe em relação aos chamados jovens repórteres. A todo o momento, Barcellos é posto como editor, apresentador e narrador principal do programa, o jornalista experiente que explica aos repórteres mais novos os elementos das reportagens e edita o que eles fizeram durante o processo de apuração. A posição do jornalista experiente é a posição séria, de condução, de domínio do código do jornalismo, do habitus - para utilizar um termo cunhado por Bourdieu - cabendo aos jovens jornalistas o espaço da experimentação, da emoção.

\section{OS JOVENS REPÓRTERES}

Um elo fundamental, como foi dito, para a construção dos discursos existentes no Profissão Repórter - o de mostrar os "bastidores da notícia e os desafios da reportagem” -, são os jovens repórteres, como são denominados os repórteres mais novos do programa pelo apresentador Caco Barcellos. Compõem a equipe de reportagem, nove repórteres: Caio $\mathrm{Ca}-$ vechini, Caroline Kleinubing, Felipe Gutierrez, Gabriela Lian, Júlia Bandeira, Mariane Salerno, Nathália Fernandes - que saiu na segunda temporada do programa -, Thaís Itaqui e Thiago Jock. Faz-se aqui necessária a utilização novamente do conceito de trajetória formulado por Bourdieu (1997), para entender qual a posição que estes mediadores ocupam na apresentação do programa.

Caio Cavechini é jornalista e documentarista. Foi convidado para participar do Profissão Repórter por seus documentários e se divide entre as duas atividades. Com os documentários, participou de vários festivais de cinema no Brasil e no exterior. No site do programa, Cavechini é definido como uma pessoa que gosta de incertezas referentes às matérias, às entrevistas que podem ser respondidas de forma inesperada, sobre sua preferência pela atividade na redação ou na rua, fazendo as reportagens. Felipe Gutierrez é formado em Administração Pública pela Fundação Getúlio Vargas (FGV) e Jornalismo na Universidade de São Paulo (USP). De acordo com o site do programa, Gutierrez ainda está se acostumando com a presença de câmeras em sua vida, preferindo ficar nos bastidores, analisando gráficos e estatísticas. 
Gabriela Lian formou-se em jornalismo pela Faculdade Cásper Líbero e também cursa Letras na Universidade de São Paulo, em português e árabe. A repórter já fez parte das equipes de Galvão Bueno, do Jornal Hoje e da Globo News, possuindo, portanto, uma trajetória considerável dentro da Rede Globo. Júlia Bandeira é formada em jornalismo pela PUC-SP e continua seus estudos na área da comunicação. Já produziu e dirigiu um documentário sobre Chico Buarque e, durante dois anos, apresentou um programa na TV PUC. A repórter, entre outras atividades, fez teatro e dança.

Mariane Sarleno é jornalista formada pela Universidade Metodista. Trabalha na TV Globo desde 2002. Já produziu, editou e coordenou reportagens. Nathália Fernandes é formada em jornalismo na USP. Há três anos, é editora de texto da TV Globo. Estava na equipe do Profissão Repórter desde o primeiro programa, em que também foi repórter em algumas matérias, mas saiu antes do início da segunda temporada do programa.

Thaís Itaqui é formada em jornalismo pela Universidade Anhembi Morumbi. É definida pelo site do Profissão Repórter como alguém cuja vontade de ser jornalista surgiu da sua necessidade de justiça. Itaqui é voluntária de uma ONG e, ainda de acordo com o site, sempre pensou que, através do jornalismo, muitas realidades ainda pouco conhecidas pudessem ser contadas e desveladas para a sociedade. Thiago Jock, assim como Caio Cavechini, também é jornalista e documentarista.

Os dois repórteres que entraram mais recentemente no programa são Felipe Suhre, que é formado em jornalismo pela UniverCidade do Rio de Janeiro, e Caroline Kleinubing, recém-formada em jornalismo pelo Centro Universitário Franciscano. Segundo o site Memória Globo, Suhre possui pouca experiência em TV, mas sempre quis ser repórter, por acreditar na importância de ouvir e contar histórias. Além disso, é formado como ator.

A maioria dos repórteres do programa é de São Paulo e entrou no Profissão Repórter após participarem do programa de estágio da TV Globo. A exceção a esta etapa do processo de escolha fica a cargo de Cavechini e Bandeira. Isto mostra um vínculo institucional do programa com a Rede Globo. Não é qualquer jovem repórter que participa do programa, mas aqueles que passaram pelo programa de estágio da TV. Cavechini e Bandeira foram selecionados depois dos responsáveis pela formulação do 
programa terem visto documentários feitos por eles. Nas edições do dia 14 de outubro e 17 de novembro de 2008, os repórteres Gabriela Lian, Caio Cavechini e Júlia Bandeira, além das reportagens, assumiram a posição de edição e produção executiva.

Uma informação que precisa ser extraída da observação destas trajetórias é que nem todos os jovens repórteres são tão jovens quanto a ideia que o programa quer passar. A repórter Mariane Salerno já trabalha, na Globo, há sete anos, um tempo grande de experiência, tendo produzido, editado e coordenado reportagens naquela rede de televisão. Conforme será demonstrado no tópico a seguir, Salerno foi escolhida para acompanhar os candidatos a uma vaga no processo seletivo realizado pelo Profissão Repórter em 2009.

$\mathrm{Na}$ entrevista concedida ao jornal $\mathrm{O} G l o b 0^{4}$, o diretor do programa, Marcel Souto Maior, afirmou que um dos objetivos do programa é buscar gente nova, supostamente, com um olhar mais curioso do que um jornalista experiente. Este discurso serve para atribuir aos jovens repórteres uma posição de maior liberdade em relação à atividade desempenhada no programa. Além disto, são mostradas todas as reações dos jovens repórteres como se eles fossem mais um dos personagens, cuja história é de envolvimento na produção das reportagens. Sobre o discurso de uma visão mais curiosa, a análise do programa nos permitiu ver outra coisa. Esta condição de pretensa liberdade e experimentação é contraposta ao papel desempenhado pelo jornalista Caco Barcellos, de jornalista experiente. É ele, por exemplo, que tem a palavra final.

Esta busca por gente nova justificaria a presença de uma repórter convidada por Marcel Souto Maior, na edição do dia 18 de novembro, cujo tema foi "Comida". Naquela edição, a repórter Inara Chayamiti foi anunciada como a "convidada da semana" por Caco Barcellos e ficou a cargo dela a frente de reportagem que cobriu a realização de um jantar que reuniu chefs de cozinha de todas as partes do mundo. Nas vinte edições analisadas neste artigo, houve apenas dois convidados. Uma foi Chaya-

4 Disponível em: <http://oglobo.globo.com/cultura/revistadatv/mat/2008/11/14/conheca_os_bastidores_dos_bastidores_da_noticia_profissao_reporter_-586406138.asp $>$. Acesso em: 27 out. 2009. 
miti e ficou nítido na tela que ela estava na posição de novata. Ela chegou a dizer que estava perdida diante das câmeras.

As cenas de bastidor que mostram a repórter convidada serviram para demonstrar que ela não domina a linguagem de TV, não está acostumada com o ambiente do evento e esquece, inclusive, de perguntar o nome de uma fonte, sendo este mais um recurso para a construção do discurso do programa sobre o telespectador acompanhar o processo de produção da notícia. E, além disto, é utilizado para reforçar o discurso de que aquele é um espaço que serve de experimentação e de oportunidade para os repórteres mais novos.

O outro foi Renan Pinheiro, jornalista da TV Bahia, e convidado na edição do dia 12 de maio de 2009, em que foi ao ar a edição sobre "Artistas da Noite". Pinheiro foi responsável por uma das frentes de reportagem em Salvador, onde teria como desafio mostrar artistas interessantes que ele encontra na rua da capital baiana, conjuntamente com o repórter Felipe Gutierrez, um dos responsáveis por uma das câmeras naquele dia. Diferentemente de Inara Chayamiti, a participação de Renan Pinheiro no programa não foi centrada em suas dificuldades em se posicionar perante a câmera. O discurso utilizado para ele, por Caco Barcellos, foi de que ele conhece bem a cidade. No entanto, mais uma vez, não foi explicado o porquê de eles terem sido os jovens repórteres daquelas edições e nem o motivo de terem sido apenas dois em 20 programas analisados.

\section{OS JOVENS REPÓRTERES MAIS JOVENS}

Dentre os nove repórteres que compõem a equipe do Profissão Repórter, há dois deles que são os mais jovens de todos: Felipe Suhre e Caroline Kleinubing. Os dois entraram no programa na temporada 2009. Suhre entrou logo na primeira edição do programa, tendo sido anunciado por Caco Barcellos durante a entrevista ao programa Vídeo Show. Kleinubing foi a ganhadora do processo seletivo empreendido pelo programa nesse ano. A condição de novatos dos dois é reforçada pelo programa. No primeiro programa que foi ao ar, "Desafios da Balança”, Suhre é apresentado como novato desde o primeiro momento em que entrou na redação. 
Com a entrada em cena dos novatos, podemos ver ainda que é criada uma hierarquização entre os jovens repórteres. Suhre precisa da ajuda de Thaís Itaqui e esta ajuda é enunciada no programa, mostrando a sua condição de novato e a dela não tão novata, possuindo mais experiência do que ele, o que confere a ela uma posição intermediária entre o repórter experiente - Caco Barcellos - e o completamente novato. Afirmamos isto, porque todos eles realizam as suas frentes de reportagem em dupla, ou seja, também precisam de auxílio, mas isto não fica demarcado discursivamente na tela, como no caso dos novatos. Além disto, o fato de alguns deles como Júlia Bandeira assumirem, frequentemente, a posição de produção executiva do programa aponta para esta hierarquização.

A realização das frentes de reportagem em dupla como foi citado no parágrafo anterior permite que seja repensado o papel dos mediadores na construção de um programa telejornalístico. Quando Caco Barcellos anuncia os repórteres, ele cita os que estarão na frente das câmeras e os que estarão manuseando as câmeras, conferindo, discursivamente, às duas atividades o mesmo peso na construção das reportagens, chamando a ambos de repórteres. Além disto, constantemente, os repórteres que estão com a câmera aparecem na tela portando uma câmera menor, tendo sido filmados por outro cinegrafista que não é anunciado por Barcellos.

A aparição dos repórteres com as câmeras, que são do tipo mini-DV, não se tratando, portanto, de uma câmera profissional - a distinção entre o cinegrafista com a câmera profissional e o outro fica evidente na qualidade da imagem mostrada -, destaca neste programa o papel que os cinegrafistas possuem nos bastidores da produção das reportagens televisivas. Além disto, as diferentes qualidades de imagem são uma estratégia utilizada pelo programa para ressaltar a condição de bastidores, de apresentar o making of, e estabelece como pacto do programa sobre o papel do jornalismo uma relação com a transparência, ao mostrar aquilo que está sendo feito para a audiência; com a autenticidade do trabalho dos repórteres e com a construção da veracidade daquilo que está sendo mostrado.

A outra novata só apareceu no Profissão Repórter na sétima edição do programa, na temporada 2009, com título de "Vida de Bombeiro". Caro- 
line Kleinubing foi a ganhadora de um processo seletivo que teve início no primeiro programa do ano. A seleção foi anunciada durante a entrevista concedida por Caco Barcellos ao Vídeo Show, anteriormente citada nesta análise. Marcel Souto Maior, diretor do programa, afirmou que as inscrições seriam abertas naquele dia e que eles dariam oportunidade para repórteres formados em 2007 e 2008.

Em todas as edições, antes de chegar à edição citada acima, Barcellos antes de encerrar o programa chamava a atenção da audiência para o processo seletivo. No primeiro programa, anunciou que as inscrições estavam abertas na internet. No segundo programa, informou que os interessados tinham até a outra semana para se inscrever. No programa de número quatro, disse que 30 candidatos haviam sido classificados, após a avaliação dos vídeos que haviam sido enviados. No quinto programa, Barcellos afirmou que eles já tinham os semifinalistas. No sexto, ele disse que os três teriam que gravar uma reportagem nas ruas de São Paulo. Reportagem esta exibida na edição de número sete. Estas reiteradas falas de Barcellos serviram para atualizar a audiência sobre o processo seletivo que estava em curso no programa e também para ir criando uma expectativa em relação ao desfecho. Além disto, conferiu relativa transparência ao processo seletivo, permitindo que os telespectadores assistissem às diferentes etapas do processo de seleção.

Acreditamos ainda que esta ideia de mostrar a escolha de um repórter no programa o aproxima de alguns realities shows, cujo prêmio é um emprego. O Aprendiz, reality exibido pela Rede Record no mesmo horário do Profissão Repórter é um exemplo de programa que dá uma vaga em uma das empresas do publicitário Roberto Justus, propiciando o contexto televisivo ideal para que esta ideia fosse colocada em prática. O fato dos dois ocuparem o mesmo horário da grade televisiva, um na Rede Record de Televisão e outro na Rede Globo, fortalece esta noção da relação entre um produto e outro. E, assim como em O Aprendiz, a escolha coube à produção do programa. Assim, um programa jornalístico, no caso aqui analisado, o Profissão Repórter utiliza mais um recurso encontrado facilmente em um programa do campo do entretenimento, articulando-o à necessidade de informar sobre o processo seletivo. 
Outro ponto que aproxima os dois programas é o fato de que os candidatos a uma vaga tanto em um quanto no outro são jovens, permitindo inferir, junto com o fato da abertura se assemelhar a um videoclipe, o quadro de repórteres ser formado por jovens oriundos do programa trainee da rede de televisão, a utilização recorrente de termos coloquiais, tais como "vamo lá", e ainda ter o apresentador Caco Barcellos como uma espécie de editor-professor, que o programa quer se endereçar a uma audiência formada prioritariamente por jovens.

Agora, explicaremos como foi a edição que mostrou o processo seletivo. Os candidatos a uma vaga de repórter integrante do Profissão Repórter, para não fugir ao esquema formulado pelo programa, foram anunciados por Caco Barcellos. Eles foram sendo mostrados um a um entrando na redação do programa. Barcellos explicou as regras do jogo, dizendo o que o programa espera daquele que vai ganhar o processo seletivo. No decorrer desta edição, foram sendo mostrados trechos das reportagens de todos os candidatos, os três agrupados na mesma frente de reportagem. O resultado só veio no segundo bloco. Mais uma vez, o programa utilizou o modo de comunicação do storytelling, desta vez para relatar o processo seletivo do mais novo repórter integrante do produto televisivo aqui analisado. O telespectador acompanhou todo o desenvolvimento da realização das reportagens pelos repórteres-candidatos - as histórias contadas pelos três foram sendo mostradas compondo uma das frentes do programa -, teve a atenção retida quando foi dado o clímax - antes do intervalo comercial - e assistiu ao desfecho: a escolha de Caroline Kleinubing.

\section{CONSIDERAÇÕES FINAIS}

Após a observação dos modos de comunicação do programa e as trajetórias dos mediadores, acreditamos ser necessário sintetizar todas estas características a fim de definir o modo de endereçamento do programa. Em primeiro lugar, há que se destacar que, no Profissão Repórter, os jornalistas são repórteres e personagens. Eles cumprem o papel de repórter, na frente de reportagem, ao mostrarem o processo seletivo dos guarda-vidas, informando como ele acontece, mas também, se mostram como personagem ao chorar. 
Além disto, acreditamos que, ao colocar Caco Barcellos como narrador principal das histórias, o repórter experiente que tem o voto final, o programa convoca toda a trajetória de reconhecimento e notoriedade deste jornalista no interior do campo profissional ao qual está vinculado e, na relação deste com a sociedade, para estabelecer o pacto sobre o papel do jornalismo ali executado através do reforço de um dos valores configuradores deste campo que é a veracidade estabelecida através da credibilidade do mesmo. Outros valores do pacto como objetividade e imparcialidade também são requisitados pelo programa, sendo reforçados estrategicamente através de dispositivos discursivos e audiovisuais, como na edição em que a repórter Gabriela Lian foi atrás do médico Marcelo Caron. O programa ainda, através das suas escolhas temáticas, relaciona-se com os valores do interesse público e de jornalismo como serviço quando apresenta, no encadeamento das histórias, médicos e especialistas, como na edição sobre transtornos alimentares.

Por fim, acreditamos que mais um elemento necessário para o entendimento da forma em que se dá o modo de endereçamento do Profissão Repórter está no contexto comunicativo em que o telespectador é inserido. Neste quesito em especial, achamos importante mostrar que a audiência do programa assume, principalmente, duas posições no contexto comunicativo. Em um dado momento, ela é a testemunha das histórias que ali estão sendo mostradas, mesmo que, em nenhum momento, os repórteres falem diretamente para os telespectadores, utilizando pronomes pessoais, tais como "você". Ao mostrar os bastidores do processo de produção das reportagens, as reações dos repórteres e das fontes, a audiência é convidada a assistir todas aquelas etapas, a compartilhar as emoções com os repórteres e com os personagens ali mostrados. Em outro momento, os telespectadores são convidados diretamente para participar do programa, nem que seja em outro meio, no caso a internet. Em todas as edições analisadas, o principal mediador do programa, Caco Barcellos, faz esta convocação dizendo que o programa não termina naquele momento e que ele continua na internet. Nesta hora, Barcellos se direciona diretamente para a audiência olhando para a câmera e utilizando o pronome "você". Na internet, os telespectadores podem co- 
mentar as edições dos programas, participar com sugestões de personagens, acompanhar o desenvolvimento de algumas histórias contadas no programa, participar de chats com especialistas, saber de mais bastidores das reportagens que não foram mostrados durante a edição exibida na TV. É como se, naquele espaço, para além da função de testemunhas das histórias, eles fossem posicionados como participantes daquelas histórias.

Através da observação dos operadores de análise, dos modos de comunicação e do uso da internet pelo Profissão Repórter, entendemos que o programa se endereça aos seus telespectadores como um programa que fala sobre jornalismo, tendo em Caco Barcellos o seu principal elemento configurador e cuja posição, construída em contraposição aos jovens repórteres, é utilizada para explicar o processo de construção das reportagens. O argumento de que ali são mostrados os bastidores da notícia e os desafios da reportagem se articula com esta função adotada por Barcellos e a equipe de reportagem do programa. A sua trajetória no jornalismo investigativo influencia o programa através da utilização do termo "frentes de reportagem", a busca dos dois lados da história mesmo quando elas não querem depor, e o fato dele ser o jornalista experiente o credencia a assumir todas as funções diversas que ele possui no programa: apresentador, editor, professor, repórter e narrador principal.

Aos jovens repórteres, é dado o lugar do inexperiente, aquele que ousa, que quer aprender, que não possui ainda a perícia técnica do experiente. Todas as estratégias utilizadas, para além das histórias contadas, têm como objetivo possibilitar ao telespectador acessar o processo de construção das reportagens. Podemos afirmar, após todas as considerações feitas no percurso desta análise, que o programa estabelece em torno de si uma função metalinguística do jornalismo, em que os jornalistas explicam as suas práticas profissionais no decorrer da produção das histórias ali relatadas, com Barcellos sendo a figura que assume, retoricamente, a posição do sujeito que explica para os telespectadores os bastidores e os desafios de se fazer uma reportagem na televisão. 


\section{REFERÊNCIAS}

BAIÃO, Júlia. Caco Barcellos fala sobre a evolução do Profissão Repórter. 13 maio 2009. Disponível em <http://oglobo.globo. com/cultura/kogut/posts/2008/07/20/caco-barcellos-falasobre-evolucao-do-profissao-reporter-114701.asp>. Acesso em: 12 abr. 2009.

BORELLI, Silvia H. S.; PRIOLLI, Gabriel (Coord.). A deusa ferida: por que a Rede Globo não é mais a campeã absolta de audiência. São Paulo: Summus, 2000.

BOURDIEU, Pierre. The political field, the social science field, and the journalistic field. In: BENSON, Rodney; NEVEU, Erik. Bourdieu and the journalistic field. Londres: Polity Press, 2005. P. 29-47.

Razones prácticas: sobre la teoria de la acción. Barcelona: Letra E, 1997. . On Television. Nova York: The New Press, 1998;

BRAVO, Zean. Caco Barcellos fala sobre o 'Profissão Repórter' e faz revelações. O Globo, Rio de Janeiro, 11 ago. 2008. Revista da TV. Disponível em: <http://oglobo.globo.com/cultura/ revistadatv/mat/2008/08/08/caco_barcellos_fala_sobre_ profissao_reporter_faz_revelacoes-547639864.asp>. Acesso em: 12 abr. 2009.

DAHLGREN, Peter. Introduction In: DAHLGREN, Peter; SPARKS, Colin. Journalism and Popular Culture. London: Sage, 2000. p. 1-23.

EKSTRÖM, Mats. Information, Storytelling and attraction: TV journalism in three modes of communication. Media, Culture $\mathbb{E}$ Society, London, SAGE, v.22, p. 465-492, 2000.

GOMES, Itania Maria Mota. O embaralhamento de fronteiras entre informação e entretenimento e a consideração do jornalismo como processo cultural e histórico. In: DUARTE, 
Elizabeth Bastos; CASTRO, Maria Lília Dias de (Org.). Em torno das mídias. Porto Alegre: Sulinas, 2008.

. O infotainment na televisão. In: ENCONTRO ANUAL DA COMPÓS, 18., 2009, Belo Horizonte. [Anais...] Belo Horizonte: PUC, 2009. GT de Mídia e Entretenimento.

. O que é o popular no jornalismo popular. In: FREIRE FILHO, João; GRANJA COUTINHO, Eduardo; PAIVA, Raquel (Org.). Mídia e poder: ideologia, discurso e subjetividade. Rio de Janeiro: Mauad X, 2008.

Questões de método na análise do telejornalismo: premissas, conceitos, operadores de análise. E-Compós, v. 8, 2007.

; GUTTMAN, Juliana; SANTOS, Thiago. Eles estão à solta, mas nós estamos correndo atrás: jornalismo e entretenimento no custe o que custar. E-Compós, v.11, n. 2, 2008.

HUGHES, Marília. O modo de endereçamento do Globo Repórter: uma análise a partir de três períodos historicamente distintos. 2009. Dissertação (Comunicação) -Faculdade de Comunicação da Universidade Federal da Bahia. Salvador.

MEMÓRIA GLOBO. Profissão Repórter. [2008]. Disponível em: <http://memoriaglobo.globo.com/Memoriaglobo/0,27723,G YN0-5273-268972,00.html >. Acesso em: 12 abr. 2009.

MENDONÇA, Olívia. Conheça os bastidores dos bastidores da notícia, o 'Profissão Repórter'. O Globo, Rio de Janeiro, 17 nov. 2008. Revista da TV. Disponível em: <http://oglobo.globo.com/ cultura/revistadatv/mat/2008/11/14/conheca_os_bastidores_ dos_bastidores_da_noticia_profissao_reporter_-586406138. asp>. Acesso em: 12 abr. 2009.

ORTIZ, Renato. A moderna tradição brasileira: cultura brasileira e indústria cultural. São Paulo: Brasiliense, 1988. 
PORTO, Mauro. TV news and political change in Brazil: the impact of democratization on TV Globo's journalism. Journalism, v.8, n. 4, London: Sage, p. 381-402, 2007.

PROFISSÃO REPÓRTER. Disponível em <http:/ / profissaoreporter.globo.com>. Acesso em: 12 abr. 2009.

SANTOS, Thiago Emanuel Ferreira dos. Infotainment e Telejornalismo: as estratégias de endereçamento do Profissão Repórter. 2009. 94f. Trabalho de Conclusão de Curso (Bacharelado em Comunicação) Faculdade de Comunicação, Universidade Federal da Bahia. Salvador 


\title{
Telejornalismo na TV pública brasileira. Uma análise do Repórter Brasil
}

\author{
Valéria Vilas Bôas Araújo
}

INTRODUÇÃO

O Repórter Brasil é a primeira produção jornalística da TV Brasil, a emissora pública instituída pelo governo Lula. Foi ao ar pela primeira vez no dia 03 de dezembro de 2007, uma segunda-feira, um dia depois da estreia da nova emissora. Sendo a Empresa Brasil de Comunicação (EBC) e, portanto, a TV Brasil produto da união entre a Radiobrás e a TVE Rio, o Repórter Brasil veio substituir os antigos telejornais das duas emissoras, o Repórter Nacional e o Edição Nacional ${ }^{1}$, respectivamente.

A missão do Repórter Brasil, contudo, vai além da simples substituição. Por ocasião do seu lançamento, o gerente de jornalismo da EBC, Eduardo Castro, declarou que era um desejo antigo das direções de emissoras públicas no Brasil criar um telejornal unificado, em que Estados distantes dos grandes centros pudessem ter a mesma possibilidade de estar no ar. Para Helena Chagas, diretora de jornalismo da emissora, "[...] a idéia é que o Repórter Brasil seja, de fato, um jornal nacional, como acho que não temos hoje em dia". (MACEDO, 2007) Ela reconhece, entretanto, que as condições técnicas para que esse objetivo seja cumprido não são muito favoráveis. (MACEDO, 2007) A maior aposta do Repórter Brasil é mostrar o país que traz no nome, de um jeito como ele não é visto nas emissoras comerciais, como assegura Eduardo Castro:

A gente vai mostrar o Brasil numa perspectiva que a gente hoje, na tevê comercial, poucas vezes vê. A gente vai mostrar o Brasil a partir daquilo que faz o próprio cidadão por meio das suas inicia-

1 Repórter Brasil inaugura o jornalismo unificado da TV pública da EBC. Disponível em: <http:// www.agenciabrasil.gov.br/noticias/2007/11/30/materia.2007-11-30.4143275408/view>. Acesso em: 4 nov. 2008. 
tivas de áudio e de vídeo e também vai mostrar com base naquilo que é feito nos outros estados, nas outras emissoras públicas, tanto emissoras educativas quanto emissoras universitárias, emissoras comunitárias, enfim; a gente quer que esse campo tenha na EBC um lugar pra mostrar o material que produz e mostrar o Brasil de um jeito que hoje em dia ele não é visto. (TV BRASIL..., 2007)

O telejornal é apresentado em duas edições diárias, uma às $8 \mathrm{~h}$ da manhã e outra às 21 horas. A primeira edição é apresentada direto de Brasília. A segunda, até 14 de abril, foi ancorada de Brasília e do Rio de Janeiro, as duas praças principais. A partir dessa data, passou a ser apresentado também de São Paulo para que a cidade tivesse mais destaque no noticiário. (DIAS, 2008) A nossa escolha foi analisar somente a edição noturna², das 21 horas, visto que essa é a edição do horário nobre e oferece melhores elementos para a análise, como a apresentação a partir de três praças, por exemplo, que não acontece na edição matutina, apresentada apenas de Brasília.

A proposta do Repórter Brasil, ainda segundo Eduardo Castro, em entrevista cedida a Soalheiro (2007), é fazer um jornalismo mais atento ao que interfere diretamente na vida do telespectador. A nossa intenção aqui é analisar de que modo o jornalismo público da TV Brasil se apresenta no Repórter Brasile de que modo ele se endereça a seu público. Qual a noção de cidadão e cidadania inscrita nele? O que ele sugere para um novo modo de fazer jornalismo no Brasil? O que lhe é próprio enquanto produto jornalístico televisivo? Qual pacto sobre o papel do jornalismo estabelece com seu público?

Os cenários são simples, compostos por bancada de madeira com tampo prateado, tela de $\mathrm{LCD}^{3}$ e um espaço destinado às entrevistas - no estúdio do Rio, a própria bancada abriga o eventual entrevistado que ocupa um espaço idêntico ao do entrevistador, ao lado dele. Em Brasília e São Paulo, o apresentador recebe entrevistados em uma sala de estar com

2 A análise apresentada neste capítulo é referente às edições dos dias 12 de agosto a 13 de setembro de 2008, com exceção das edições dos dias 22 e 28 de agosto.

3 Monitor de cristal líquido, do inglês: Liquid Cristal Display. 
poltronas e outra tela de LCD. Os dois espaços sugerem uma proximidade entre quem pergunta e quem responde, e, ao menos espacialmente, uma relação de igualdade.

Os três apresentadores titulares do Repórter Brasil são Lincoln Macário, em Brasília, Luciana Barreto, no Rio, e Florestan Fernandes Júnior, em São Paulo, mas apesar de esta ser a equipe que consta no site do noticiário, outros apresentadores são frequentes no comando no telejornal. Aos sábados, o programa é geralmente apresentado de Brasília, por Fernanda Isidoro ou Natália Pereira ${ }^{4}$, mas pode ser transmitido também dos estúdios de São Paulo ou Rio. Cristina de Lamônica (Brasília), Carla Ramos (Rio de Janeiro), Ana Luísa Médici (São Paulo e Brasília) e José Donizete são apresentadoras ocasionais do noticiário. Todos têm passagens anteriores por emissoras públicas, estatais ou educativas, como TV Justiça, TVE Rio ou TV Nacional. No período da nossa análise, a jornalista e atleta Carla Maia foi convidada para integrar a equipe do telejornal como apresentadora das notícias das Paraolimpíadas de Pequim.

De todos os nomes, o de maior destaque é, sem dúvida, o do jornalista Florestan Fernandes Júnior, filho do sociólogo Florestan Fernandes - militante de causas públicas como a educação gratuita e universal, as políticas afirmativas, a reforma agrária. Júnior formou-se em jornalismo em 1977 e foi apresentador da TV Nacional antes de assumir o cargo de diretor do departamento de Jornalismo da TV Brasil. O jornalista foi também repórter dos jornais Folha de S. Paulo e Jornal da Tarde, repórter da TV Cultura, da TV Globo e da TV Manchete, além de editor do Jornal da Gazeta. Mesmo com um currículo considerável e o nome notório que herdou do pai, o jornalista não é muito conhecido na televisão, não é uma estrela. A sua presença confere credibilidade ao telejornal, mas, assim como os outros apresentadores, ele pode ser substituído, inclusive no meio da semana. A substituição de nenhum dos apresentadores precisa ser justificada. No período analisado, a praça que teve maior número de apresentadores foi Brasília, com quatro, enquanto São Paulo teve três e o Rio apenas dois.

4 As edições de sábado têm menor duração e costumam ser mais “leves”, com poucas notícias de economia e política e mais matérias sobre arte, esportes, lazer. 
Já na escalada, três apresentadores dividem a narração das matérias. Na edição de 04 de setembro, Luciana Barreto, Florestan Fernandes e Lincoln Macário apresentam os destaques do dia. As falas, em off, são acompanhadas de imagens de cada uma das notícias: o novo "caveirão", a revolta de populares em Buenos Aires, o Ministro da Saúde discursando no Supremo Tribunal Federal. Após essa sequência, surge uma montagem de três pequenas telas dispostas sobre um fundo azul com o logotipo do noticiário no canto inferior direito. Embaixo de cada uma das pequenas telas, os caracteres indicam o nome da cidade onde está o apresentador que nela aparece. Esse esquema é repetido por todo o noticiário: as matérias apresentadas são chamadas, cada uma por um apresentador assuntos de Brasília, Rio de Janeiro e São Paulo são sempre apresentados do estúdio da cidade (ou Estado) em questão; as outras regiões aparecem geralmente através de produções de emissoras regionais, nem sempre citadas pelos apresentadores, embora no interior das matérias seja possível perceber de quem é a produção pela identificação na corola do microfone ou pelos créditos de imagem.

Embora a proposta declarada do Repórter Brasil seja fazer um jornalismo "nacional de fato, como não encontramos nos telejornais hoje", o enfoque predominante do noticiário é o do eixo Rio-São Paulo-Brasília, não só porque a apresentação do telejornal é feita destas três cidades, mas, sobretudo, porque as matérias de âmbito "nacional" são geralmente elaboradas a partir de um exemplo generalizado original destes centros simbólicos. Isso poderia se explicar, em parte, pelo fato de que a estrutura técnica da emissora está montada nestas três cidades, mas, considerando que a TV Brasil tem um centro de produção também em São Luís do Maranhão e a incidência do Estado no noticiário é mínima ${ }^{5}$, acreditamos que a escolha por privilegiar este eixo tem a ver com o fato de que estas três cidades são consideradas centros de decisão política, econômica e cultural do país. As matérias de âmbito nacional, por exemplo, são todas produzidas por essas três praças, fundadas em um discurso sobre

5 Durante o período analisado, a cidade de São Luís do Maranhão apareceu apenas uma vez, através de uma notícia sobre um temporal que alagou as ruas da cidade em 18 de agosto. 
o cidadão que é afetado pelas decisões do Congresso e pelas oscilações da economia, esteja no Acre ou em São Paulo.

As matérias das emissoras afiliadas, produzidas em diversos Estados do país, geralmente aparecem no telejornal para apresentar uma situação particular ou para particularizar um tema que esteja na agenda do Repórter Brasil. Assim, quando o jornal discutia a "crise" nos transplantes de órgãos, no Rio de Janeiro, motivado pela denúncia de um esquema de compra de órgãos, as matérias factuais sobre queda do número de doações e a morte de D. Vanda, que há cinco anos esperava por um transplante de fígado, se opõe à matéria produzida pela TV Ceará, que mostra o sucesso da implantação de uma comissão para cuidar de transplantes, no Hospital de Mecejana, em três de setembro. Ou, ainda, matérias sobre as plantações de morango e mexerica, em Minas Gerais, e o desenvolvimento de uma técnica para plantar bambus em laboratório, no Acre, ganham espaço a partir da divulgação dos bons indicadores para o crescimento da economia do país atrelada à produção de alimentos. Fora esta condição, as matérias das afiliadas costumam aparecer dando conta de fatos ocasionais - como o aparecimento de uma baleia morta em uma praia em Aracaju, Sergipe - ou através de matéria sobre turismo e meio ambiente, raramente para tratar de assuntos de âmbito nacional de forma mais geral.

O discurso do Repórter Brasil baseia-se fundamentalmente na ideia da cidadania. Assim, as decisões do Congresso afetam diretamente a sua vida, os gastos do Governo saem do seu bolso. Na edição de treze de agosto, Cristina de Lamônica chama a repórter Karine Melo ao vivo, de Brasília:

CABEÇA - Aprovações no Congresso que mexem com a vida de cada um. Foi criado o micro empreendedor e a licença maternidade ganha mais tempo. A repórter Karine Melo acompanhou as votações e tem os detalhes ${ }^{6}$.

6 Cristina de Lamônica. Programa Repórter Brasil, exibido em 13 de agosto de 2008. 
As entradas ao vivo de Brasília são corriqueiras, mas a tendência dessas entradas não é noticiar primordialmente o jogo e as disputas políticas - embora essas disputas também tenham espaço -, mas atualizar notícias sobre a tramitação de projetos ou decisões de Governo que tenham influência direta na vida do cidadão, como no caso citado acima. A política, que parece sempre externa ao cotidiano das pessoas, é apresentada como parte dele - "aprovações que mexem com a vida de cada um". No entanto, o cidadão continua passivo diante destas decisões, recebendo o resultado do que a instituição Estado resolveu. A matéria apresentada em 13 de agosto sobre a licença maternidade leva o telespectador a "entender" a nova regra, como afirma imperativamente o texto da escalada do programa. A cidadã mãe será simplesmente uma beneficiária da nova Lei:

CABEÇA - Para valer, falta o Presidente Lula assinar o projeto que o Congresso aprovou. A licença maternidade passa de quatro para seis meses. Na Lei aprovada, as funcionárias públicas ganham o benefício imediatamente ${ }^{7}$.

Apenas mulheres aparecem desde a cabeça até o fechamento da matéria no estúdio (notapé). Essa construção contribui no sentido de criar laços de identificação - quem fala é alguém que faz parte do mesmo mundo da telespectadora, é um igual -, pois são todas protagonistas da mesma cena. A fala da deputada federal Rita Camata, no final da matéria, funciona como uma garantia do legislativo, de que essa Lei não trará nenhum prejuízo à vida profissional da mulher, questão muito debatida à época.

A deputada é uma fonte oficial, que transmite credibilidade ao programa pelo recurso da voz autorizada. De modo geral, esse é o tipo de fonte privilegiada pelo Repórter Brasil - o especialista, a autoridade, o representante de uma instituição. Na edição de dezoito de agosto, o início do Horário Eleitoral Gratuito, que aconteceria no dia seguinte, mereceu destaque - uma matéria falava da importância que ele tem para o processo eleitoral e para o fortalecimento da democracia, mas chamava

7 Cristina de Lamônica. Programa Repórter Brasil, exibido em 13 de agosto de 2007. 
a atenção, sobretudo, para o porquê da gratuidade. À matéria, seguiu-se uma entrevista realizada no estúdio do Rio de Janeiro, por Luciana Barreto, com Carlos Eduardo Caputo Bastos, Ministro do Tribunal Superior Eleitoral (TSE). Tanto na matéria, quanto na entrevista, a voz é dada às fontes oficias, sejam representantes do governo, de instituições de ensino, especialistas em direito. Na construção da matéria, o telejornal contextualiza a questão e depois abre espaço para as vozes autorizadas convocadas a ampliar o olhar sobre a questão. Assim, o Repórter Brasil recorre ao advogado e ex-ministro do TSE, Fernando Neves, ao professor de comunicação da UNB, Paulo José Cunha, e ao Procurador Eleitoral do Pará, Ubiratan Gazetta, que falam sobre a importância do horário eleitoral para o fortalecimento da democracia, alertam os eleitores sobre as artimanhas usadas pelos candidatos para atraí-los, lembram que ataques muito fortes à honra do adversário pode chegar a ser crime. E é nesse contexto que o cidadão é visto como um agente social, pela participação institucionalizada através do voto, pela eleição de representantes.

$\mathrm{Na}$ tentativa de construir uma suposta imparcialidade, o Repórter Brasil recorre quase sempre às fontes institucionais ou especializadas. O cidadão é, geralmente, fonte ilustrativa. O Presidente da República, pelo cargo que ocupa, tem espaço assegurado, ainda que seja para falar de futebol$^{8}$. Depois dele, os ocupantes de cargos institucionais do Congresso e do Senado e os Ministros são usados como fontes, por representarem as Casas e os Ministérios. Fora isso, os políticos têm voz enquanto relatores de processos ou envolvidos em casos de destaque. Em matéria de 05 de setembro sobre as escutas telefônicas realizadas pela Agência Brasileira de Inteligência (ABIN), por exemplo, as três sonoras são divididas entre um procurador da república, o presidente do senado, Garibaldi Alves, e o senador Demóstenes Torres, que teve telefones grampeados na operação da ABIN.

As entrevistas também dão lugar às vozes autorizadas. É o entrevistado, por sua especialidade e autoridade, quem dá um parecer, emite sua

8 No dia 5 de agosto, o presidente Lula criticou a atuação da seleção brasileira e elogiou o desempenho de Messi, jogador da Argentina. O comentário causou irritação entre a equipe brasileira e foi tema de uma matéria no Repórter Brasil. 
opinião, geralmente técnica, "independente" da opinião do programa, que não se manifesta declaradamente. O apresentador não questiona incisivamente, não faz um papel de investigador, ele é um mero mediador entre o público e o entrevistado, ele está ali como ponte. Em algumas ocasiões a população é convocada a perguntar. A edição de uma matéria sobre nepotismo é seguida por uma entrevista com Cláudio José Montesso - presidente da Associação Nacional dos Magistrados do Trabalho (ANAMATRA). Depois de fazer duas perguntas ao entrevistado, Cristina de Lamônica anuncia a participação:

Cristina de Lamônica - "Nós temos uma pergunta da população".

Rafael Cairo - estudante: "Eu queria saber se eu passasse em algum concurso público, se algum parente meu até terceiro grau, se eu podia assumir?"

As entrevistas, dentro do programa, funcionam como complementos a matérias que merecem destaque dentro da edição, como a que trata do Horário Eleitoral Gratuito, por exemplo. Nesse caso, Luciana Barreto recebe, nos estúdio do Rio de Janeiro, o Ministro do Tribunal Superior Eleitoral, Carlos Eduardo Caputo Bastos, e questiona:

Luciana Barreto - “A propaganda eleitoral gratuita no rádio e na tevê realmente bem aproveitada fortalece a democracia, como nós vimos na reportagem?"

Aqui também, o posicionamento do apresentador como alguém que tem questões apenas, e nenhuma dúvida, a partir do que o entrevistado fala, opera no sentido de construir uma suposta imparcialidade. Mesmo quando a entrevista é realizada no estúdio, com representantes de pontos de vista distintos, as perguntas são feitas a um entrevistado de cada vez, e cada um responde a seu turno - ainda que a pergunta seja endereçada aos dois entrevistados, cada um responde de acordo com o ponto de vista que defende, mas sem que haja um confronto entre as ideias, sem que eles tenham qualquer tipo de diálogo. Essa estratégia coloca a fonte, o entrevistado, como detentor de um conhecimento absoluto, verdadeiro, ainda que de acordo com um ponto de vista. E o telejornal, que media a relação entre entrevistado e público, numa perspectiva didática. Nesse sentido, a existência de um quadro intitulado Repórter Brasil Expli- 
ca é emblemática. Nas edições analisadas, o quadro apareceu três vezes - para explicar a origem do nepotismo na edição de 21 de agosto, em 26 do mesmo mês, para explicar o que é anencefalia e, em 02 de setembro, para explicar onde fica a camada pré-sal. O quadro faz uso de infográficos (como se distribuem as camadas de sal, por exemplo), recorre a especialistas, faz resumos históricos para "explicar" essas questões. Por duas vezes, o tema do quadro foi também motivo para entrevistas em estúdio.

A fala do cidadão fica restrita a espaços bem demarcados dentro do noticiário, como, por exemplo, nas enquetes realizadas pelo programa e exibidas ao final de cada bloco. O Repórter Brasil quer saber e o cidadão comum responde. Ali é este quem fala, emite opinião, diz o que pensa ser certo ou errado, mas, exceto o fato de se referirem ao "tema do dia", as enquetes não fazem parte do programa organicamente, não são comentadas, nem dão origem a qualquer tipo de discussão. Sua função é muito mais de reconhecimento do cidadão, que se vê na tela, do que de tribuna ${ }^{9}$, mesmo que a maior parte dos temas em questão seja de influência direta na vida da população. Entre os dias 12 e 16 de agosto, por exemplo, as enquetes apresentadas foram:

Dia 12 - "O que você considera na hora de escolher seu candidato?"

Dia 13 - "Por que você acha que tem tanto advogado no Brasil?"

Dia 14 - "Você confia no medicamento genérico tanto quanto no remédio de marca?"

Dia 15 - "Você sabe onde fica a camada pré-sal?"

Dia 16 - "1914 - 2008 (em referência à morte de Dorival Caymmi)"

Embora o usual seja que o povo responda a perguntas propostas pelo programa nas enquetes, o quadro pode ser usado com outros objetivos. Na edição de 16 de agosto, por exemplo, populares cantavam trechos de músicas do compositor baiano Dorival Caymmi, ou o saudavam com palavras de despedida em referência à sua morte na manhã daquele dia. O destaque do tema, aqui, se justifica pela importância da obra de Caymmi para o desenvolvimento e difusão da música e cultura brasileiras. Assim, as perguntas referem-se ao legado de Caymmi para a cultura, os

9 Desde a antiguidade, a Tribuna, ou púlpito, é o lugar elevado de onde falam os oradores. 
filhos e o povo brasileiro. Nesse sentido, as mortes de Waldick Soriano, Fernando Torres e Mestre Salu também são noticiadas. No caso de Mestre Salu, artista regional, a última fala na reportagem, que é sua, faz o papel de universalizar a música e, portanto, ele próprio.

SONORA de arquivo - Mestre Salu: "A música tem que ser universal, ela tem que permitir passar, andar, rolar o mundo com ela e ela vai, com certeza, só vai dar beleza aos que assistem”.

Há uma tendência no Repórter Brasil, inegavelmente uma herança da tradição das tevês educativas, de pensar a arte como instrumento pedagógico, com potencial transformador do ser humano. Assim, o enquadramento dado à Bienal do Livro de São Paulo é o da importância da formação de uma nação de leitores e do incentivo à leitura infantil. A arte é vista também como transformadora da realidade social, como na exposição de fotografias de parentes de vítimas da violência nas fachadas das casas de uma favela no Rio. É interessante notar que matérias sobre arte e cultura têm pouco espaço no telejornal, além de serem sempre veiculadas nos últimos blocos. Não há um enfoque sobre a diversidade cultural do Brasil, embora ela apareça timidamente ligada a outros temas. Na edição do dia 23 de agosto, uma matéria sobre a Lei que torna o ensino de música obrigatório no ensino básico do país traz uma entrevista com o músico popular Zé do Pífano, que dá a sua opinião sobre o tema, mas o enfoque primordial em nenhum momento privilegia a diversidade musical do país, mas dá ênfase ao poder da música como instrumento que leva o aluno a ter mais concentração, por exemplo.

A cobertura de eventos artísticos nacionais é também uma herança das televisões educativas. Durante o período analisado, o Festival de Cinema de Gramado ganha cobertura especial, com entrada ao vivo da repórter Glauce Tolomei, entrevistando cineastas e críticos do Palácio dos Festivais, e matérias sobre os filmes de baixo orçamento, sobre os concorrentes aos prêmios etc. Sem dúvida, o espaço dado pelo Repórter Brasil ao evento é maior que aquele dado por qualquer emissora comercial do país, contudo, embora o texto em off da matéria que encerra a cobertura dê destaque ao público, mais uma vez, a voz privilegiada é a do especialista. O filme que o público mais gostou não é apontado por ele próprio, 
mas pelo especialista, o crítico de cinema Luiz Carlos Merten: "Juventude foi o filme mais aplaudido desse festival, o que o público pelo visto mais gostou, e eu acho que os três, são encantadores"10. Embora o telejornal chegue a citar os filmes de baixo orçamento que fazem parte do Festival, a desigualdade de acesso aos meios de produção no cinema - que mesmo sendo cada vez mais acessível através das novas tecnologias de produção, continua sendo uma arte cara -, ou as formas de democratização desse acesso não é uma questão para ele.

A organização das editorias dentro do Repórter Brasil é bem definida: o primeiro bloco é geralmente composto por notícias de economia, o segundo traz as novidades da política nacional e internacional, no terceiro e quarto blocos notícias de segurança, arte, educação, esporte. Matérias de destaque, contudo, podem ganhar espaço no primeiro bloco, como a posse de Fernando Lugo, Presidente do Paraguai, em 14 de agosto de 2008.

No período analisado, essa organização foi quebrada para que as notícias sobre as Olimpíadas da China se distribuíssem pelos quatro blocos, com entradas diretas de Lincoln Macário, que apresentou o jornal direto de Pequim, ampliando o número de apresentadores nesse período para quatro.

As matérias de economia, como as de política, privilegiam o enfoque na vida do cidadão comum - o resultado da inflação na compra do mês, a educação financeira nas escolas, o perfil das mulheres como consumidoras - apesar de ganhar menos, elas gastam mais. Na edição de 03 de setembro, o assunto era o endividamento dos paulistanos e outra vez, o público recebe uma instrução do especialista, que reforça a necessidade de prestar atenção nos juros, de se preocupar. A sua fala é meramente ilustrativa da situação exemplar:

SONORA (sem identificação) - “Agora a gente tem que acertar, né? O déficit. Ter crédito, que tem que ter o nome limpo pra poder você comprar as coisas, ter crédito na praça”.

Na cobertura internacional, o grande destaque fica para a inclusão de notícias sobre lugares até então pouco vistos nos telejornais nacionais das

10 Entrevista ao programa Repórter Brasil, em 15 de agosto de 2008. 
redes comerciais, como América Latina e África, agora privilegiadas nas políticas de relações exteriores do presidente Lula. Em 05 de setembro, a emissora levou ao ar a primeira participação do correspondente Carlos Alberto Júnior, direto de Angola. Luciana Barreto, a única apresentadora negra do programa, é enquadrada em plano geral seguido de $z 00 m$-in ${ }^{11} \mathrm{e}$, em tom solene, anuncia:

O Repórter Brasil de hoje apresenta o primeiro correspondente da tevê brasileira na África. Carlos Alberto Júnior vai mostrar, a partir de Angola, como é este continente que desperta para o crescimento econômico e onde estão parte das nossas raízes culturais e raciais. E estréia em um dia muito importante para os angolanos - dia da primeira eleição depois de dezesseis anos. A última provocou o reinício da guerra civil ${ }^{12}$.

À apresentação da repórter segue-se a primeira matéria produzida pelo correspondente sobre as eleições no país e o sentimento do povo por poder votar outra vez. A construção retórica do lugar da África na nossa cultura é forte e muito simbólica. O Repórter Brasil assume o compromisso de mostrar ao Brasil, como é o lugar de onde muito do que somos veio. Contudo, a presença deste e de qualquer outro país no noticiário é sempre por um enquadramento institucional, seja de relações diplomáticas e econômicas, seja por causa de conflitos no país. O cotidiano das pessoas não é tema de matérias internacionais. "Os laços" que guardamos com a África se resumem à presença de brasileiros como voluntários nas eleições de Angola; Bolívia e Brasil têm interesses comuns em relação a fronteiras e gás, especialmente quando o país chefiado por Evo Morales passa por uma crise de autonomia. Nesse contexto, o preço de um almoço com algum dos presidentes da América Latina em Nova York, por ocasião de uma reunião do Conselho das Américas, passa a ser mais importante do que a pauta da reunião ou o que vai ser feito com a renda desse evento. A política, além de institucionalizada, é personalista, centrada na figura do presidente Lula.

11 Aproximação da câmara.

12 Luciana Barreto. Programa Repórter Brasil, exibido em 5 de setembro de 2007. 
A mesma institucionalização acontece com as questões das minorias. Durante o período analisado, a união estável entre casais homossexuais, a demarcação de terras indígenas e as prostitutas foram pauta do Repórter Brasil, mas somente as prostitutas não foram atreladas a uma questão em debate no Congresso, em Brasília. De fato, a rap reportagem de Fábio Féter extrapola o enquadramento habitual dado pelo telejornal às questões da cidadania, como discutiremos um pouco mais adiante.

É, sem dúvida, significativo que as minorias nem sempre representadas nas emissoras comercias, que geralmente acabam optando por manter temas polêmicos e de difícil aceitação por parte da audiência no âmbito da ficção, ganhem algum espaço no noticiário da TV Brasil. Mas é essencial que se amplie o debate a respeito delas, que as questões apresentadas sejam anteriores ao que já está decidido e, de certa forma, se estabelecendo. No caso da cobertura do julgamento da demarcação das terras da Reserva Raposa Serra do Sol, em nenhum momento o telejornal promove o debate sobre a questão indígena de forma mais aprofundada, mas apenas no âmbito do que está na pauta do Congresso e, portanto, na pauta das emissoras comerciais também, até porque esta foi uma questão grande que envolvia diversos interesses, especialmente econômicos.

\section{QUANDO A EBC É NOTÍCIA}

No final da primeira edição considerada nesta análise, de 12 de agosto, o Repórter Brasil anuncia o resultado do relatório produzido pela comissão corregedora que analisou a denúncia de Luiz Lobo, de que haveria ingerência do governo na TV Brasil. Através de uma nota coberta, o parecer é anunciado: CABEÇA - "O conselho curador da Empresa Brasil de Comunicação, gestora da TV Brasil reuniu-se hoje em Brasília e aprovou, por unanimidade, o jornalismo exibido no Repórter Brasil" ${ }^{13}$.

OFF - O conselho curador da EBC é uma entidade independente, composta por representantes dos mais variados estratos da sociedade e de todas as regiões do país. Foi examinada uma denúncia feita por um ex-funcionário de que o jornalismo da TV Brasil seria

13 Cristiana Lamônica. Programa Repórter Brasil, exibido em de 12 agosto de 2007. 
manipulado em favor do governo. A acusação foi considerada sem fundamento. Uma comissão avaliou o conteúdo de vinte edições do Repórter Brasil exibidas entre março e abril deste ano. O relatório elogia o equilíbrio adotado na apresentação dos assuntos e diz que o telejornal Repórter Brasil é tecnicamente correto e jornalisticamente isento ${ }^{14}$.

O jornal é o palco da prestação de contas, reivindica credibilidade e dá a "prova" de que a merece. Pelo compromisso da emissora pública com o cidadão, ele deve apresentar justificativas para suas posturas e decisões, sejam editoriais, sejam administrativas. A nota serve para mostrar o trabalho do conselho curador, apresentar ao público o funcionamento do sistema de controle que ele exerce sobre a emissora e dar garantias ao público de que ele pode confiar no jornalismo exibido ali.

Mas, de fato, a nota não explica como o relatório foi feito, não fala sequer quem são os membros do Conselho Curador que, se depender desta nota, continua sendo estranho ao público. Se a função do Conselho é representar a sociedade, ainda que não tenha sido eleito por ela, é necessário que haja uma identificação de um com o outro, mas o Conselho Curador acaba sendo apresentado como mais externo à vida das pessoas que a própria política institucional, é tão ou mais institucionalizado quanto ela pelo jornal.

A tentativa de construção da imparcialidade da nota é toda baseada no que o Conselho apresentou como parecer e na sua credibilidade, mas isso não é construído na matéria, é dado como certo. Nenhum instrumento de interatividade é convocado, nenhuma fala vem do público, ainda que pela voz de um representante do Conselho.

A "prestação de contas" que a TV Brasil faz ao seu público em nada difere do que faz qualquer emissora comercial. A denúncia que motivou a investigação sequer é citada; quem a fez, quem foi diretamente atingido por ela ou quem julgou a questão não aparecem na construção da notí-

14 Programa Repórter Brasil, exibido em 12 de agosto de 2007. Com imagens da reunião do Conselho. 
cia. O compromisso com o interesse público é prejudicado pela falta de transparência.

\section{OLIMPÍADAS NA CHINA}

Durante o período de análise, a equipe do Repórter Brasil noticiou as Olimpíadas da China e o desempenho dos atletas brasileiros na competição. Com entradas ao vivo, de Pequim, Lincoln Macário ancorava a aprsentação do telejornal também da cidade chinesa. A cobertura esportiva foi feita nos moldes tradicionais do telejornalismo brasileiro - notas cobertas anunciando resultados do dia, apresentação de quadros de medalhas e próximas competições, matérias sobre preparação e treinamento dos atletas ou sobre vitórias e derrotas dos brasileiros. Durante o nosso período de análise, é justamente na cobertura das Olimpíadas que se desenvolve melhor um discurso sobre o nacional.

O resultado final das competições suscita um debate sobre o investimento do país no Esporte e boa parte das matérias é construída no sentido de justificar o investimento - são apresentados números de investimento nos últimos anos, falas de Lula, do Ministro dos Esportes, de ex-atletas. Tudo isso acontece depois de uma psicóloga ser convidada para responder por que às vezes colhemos decepções ao invés de vitórias. O Repórter Brasil recorre aos laços de identificação cultural entre torcedores e atletas para tratar da questão - embora Florestan Fernandes anuncie a entrevista dizendo que isso é a "Síndrome de Vira Lata”, definida por Nelson Rodrigues, a psicóloga desmente tal informação, dizendo que o brasileiro hoje é muito confiante em si. Os traços culturais são importantes também na construção da série Lá e Cá, que explora semelhanças e diferenças entre Brasil e China. Na edição de 13 de agosto, a matéria da série fala da culinária nos dois países.

CABEÇA - Por mais exóticas que possam parecer as comidas da China, a base é quase a mesma do Brasil, o arroz. Para saber quais são as outras semelhanças e diferenças no cardápio a repórter Fenanda Isidoro foi a um supermercado aqui em Brasília e o repórter Lincoln Macário em outro, lá em Pequim ${ }^{15}$.

15 Cristina Lamônica. Programa Repórter Brasil, exibido em 13 de agosto de 2008. 
A matéria é guiada pela curiosidade. Já na cabeça, a culinária chinesa é apresentada como exótica e a fala dos repórteres e dos populares reforça a visão do outro como alguém estranho - "Vamos aproveitar o troco para comprar algo diferente", "Isso, pra mim, é comida de passarinho"16. Os produtos da China são citados por Fernanda Isidoro, mas em nenhum momento o estereótipo da China como um lugar longínquo e estranho é desconstruído, não se fala da cultura do povo como algo cotidiano, assim como a nossa.

Com o fim das Olimpíadas, Lincoln volta para o Brasil, mas o telejornal mantém uma equipe com repórteres na cidade e manda mais três repórteres para acompanhar as paraolimpíadas. No estúdio de Brasília, a atleta e jornalista Carla Maia, cadeirante, é incorporada à equipe do programa para apresentar as notícias paraolímpicas. Infelizmente não poderemos aqui fazer uma análise mais aprofundada desta questão, visto que as Paraolimpíadas começaram na última edição do corpus desta análise. De todo modo, o que observamos nas edições anteriores ao início dos jogos paraolímpicos e na edição de seis de setembro foi uma cobertura semelhante à dos Jogos Olímpicos, com matérias sobre a preparação e as expectativas dos atletas, antes do início dos jogos e, a partir do dia seis, com entradas ao vivo de Pequim da repórter Gilslene Nogueira, notas com resumos dos resultados, matérias sobre o desempenho das equipes, quadro de competições e de medalhas.

\section{OUTRO OLHAR}

A promessa da TV Brasil de abrir maior espaço para a participação do cidadão na sua programação e a obrigação, registrada em Lei, de estimular e exibir produção independente no horário noturno estão na origem do quadro Outro Olhar ${ }^{17}$, exibido no Repórter Brasil, sem regularidade

16 Reportagem de Fernanda Isidoro e Lincoln Macário para o programa Repórter Brasil, edição de 13 de agosto de 2008.

17 É possível assistir aos vídeos produzidos para este quadro no site do telejornal: <http://www. ebc.tv.br/ reporterbrasil/>. 
definida $^{18}$. O quadro é uma experiência de jornalismo participativo ${ }^{19}$ na tevê, e exibe vídeos produzidos pela população e selecionados pela equipe do jornal:

O OUTRO OLHAR é o espaço da sociedade no telejornal Repórter Brasil. Se você produz conteúdo informativo, como reportagens, entrevistas ou imagens que mostram a sua realidade, faça contato com nossa produção e envie seu vídeo. Mostre as histórias da sua redondeza, os assuntos que mexem com a sua vida. Participe da TV Brasil com a sua visão dos fatos sobre os mais variados temas. Por exemplo: uma reportagem sobre o desemprego na sua cidade, sobre a educação na escola do seu filho ou uma imagem sobre a saúde no posto de seu bairro. (EMPRESA BRASIL DE COMUNICAÇÃO, 2007)

O jornalismo participativo encontra sua maior expressão com o advento das mídias digitais, que tendem a descentralizar o polo emissor. Como afirmam Fonseca e Lindemann (2007, p. 87) “[... ] a idéia de participação é, justamente, descentralizar a emissão, oportunizando que mais vozes tenham vez no espaço público". A facilidade de acesso da população a telefones celulares com câmeras digitais ou mesmo o barateamento de filmadoras e a popularização de programas de edição caseiros, como o Windows Movie Maker ${ }^{20}$, possibilitam que também a TV abra espaço para a participação do cidadão no telejornal. O jornalismo participativo pode ser uma manifestação de insatisfação com as mídias tradicionais, ou uma expressão da vontade do cidadão de ser ver como notícia. Falando sobre jornalismo participativo na internet, Fonseca e Lindemann (2007, p. 6) chamam a atenção para o papel do repórter nesses casos:

18 No período que corresponde ao corpus deste trabalho, o Outro Olhar foi ao ar apenas duas vezes, a primeira em uma sexta-feira e depois, na segunda-feira seguinte, dias 15 e 18 de agosto, respectivamente.

19 O jornalismo participativo - também conhecido como jornalismo cidadão, jornalismo colaborativo ou jornalismo open source - é uma ideia de jornalismo na qual o conteúdo (texto+ imagem + som + vídeo) é produzido por cidadãos sem formação jornalística, em colaboração com jornalistas profissionais.

20 Windows Movie Maker - software de edição de vídeo bastante simples criado pela Microsoft para integrar alguns pacotes do sistema operacional Microsoft Windows. 
Por mais que haja jornalistas atuando como moderadores (o que ocorre em alguns casos, como no Ohmynews, vc repórter e FotoRepórter), o trabalho é limitado à revisão e edição do material que lhes é enviado, deixando de lado as tarefas corriqueiras que envolvem cultura profissional e enriquecem a produção jornalística. Além disso, pode-se questionar: onde fica a relevância de critérios como interesse público, veracidade, objetividade, clareza, exatidão, linguagem adequada? Tem-se uma situação em que todos esses pressupostos parecem diluir-se de tal forma que o jornalismo torna-se, pelo menos numa análise preliminar, simplista, superfcial, pouco sério.

Ao contrário do espaço destinado ao cidadão, nas enquetes propostas pelo Repórter Brasil, ao menos retoricamente, o povo ocupa o lugar máximo de protagonismo do discurso - o Outro Olhar é a visão do homem comum, sobre o mundo que o cerca, os problemas que o afligem. Na edição de 18 de agosto, Cristiana de Lamônica anuncia o vídeo da ONG Rede Rua:

CABEÇA-Ooutroolhardehojevailembraramortedemoradoresderua nocentro deSão Paulo, há quatroanos, equeatéhoje, os culpados não foram punidos. Amanhã, uma manifestação vai lembrar as vítimas. A produção das imagens é da ONG Rede Rua ${ }^{21}$.

O Repórter Brasil aceita produções em formato digital, inclusive de celulares e máquinas fotográficas digitais, mas alerta que pode exibir ou não, em seus telejornais, o material recebido. É aqui que entra o papel do jornalista - de produtor da informação, ele assume o papel de selecionador de material produzido:

[...] uma equipe fará a análise e seleção do material recebido, que poderá ser utilizado, ou não, nos telejornais. Vamos avaliar se a reportagem dá voz a todos os lados envolvidos, se precisa de auxílio da redação da TV Brasil para ouvir alguma parte, se o texto é de fácil compreensão para todos os telespectadores. (EMPRESA BRASIL DE COMUNICAÇÃO, 2007)

21 Cristina Lamônica. Programa Repórter Brasil, exibido em 13 de agosto de 2008. 
Embora reduzida, a função do jornalista acaba se tornando fundamental. Os valores profissionais são chamados a campo para regular o trabalho do cidadão comum, que é construído como o outro já no título do quadro. Além disso, a exibição dos vídeos produzidos por não-jornalistas é sempre indicada por um selo no canto superior direito do vídeo que traz a marca do quadro, o seu título. O selo no canto do vídeo, que identifica o quadro, indica que embora esteja no meio da edição do telejornal, ele não se mistura com ela.

Esse quadro, que não é de responsabilidade exclusiva da TV Brasil, acaba sendo o espaço de maior experimentação dentro do telejornal, seja na linguagem do telejornalismo, no uso de recursos tecnológicos ou na construção estética. Há, por exemplo, um uso mais livre da música como trilha de reportagens, o que rendeu à emissora, inclusive, o seu primeiro prêmio jornalístico - o Prêmio Caixa de Jornalismo Social, pela rap reportagem Favela Toma Conta, produzida por Fábio Féter, exibida no Outro Olhar, um quadro do programa. A experiência foi interessante a ponto de a diretora de jornalismo da EBC, Helena Chagas, declarar que deveria ser ampliada: "Já estamos procurando um repentista em outra cidade para esse espaço do Repórter Brasil" 22.

$\mathrm{E}$, de fato, a rap reportagem ganhou espaço no telejornal. Na edição de 26 de agosto, o "rap repórter" Fábio Féter produziu rap reportagem sobre um desfile da Daspu ${ }^{23}$, em São Paulo. O texto ritmado e cantado só é cortado por sonoras, especialmente da prostituta Jeane Eloy. A matéria é encerrada com a incidência do refrão da música "Um por amor, dois por dinheiro” do grupo de rap Racionais Mc's (2007), que diz: “um por amor dois por dinheiro/ na selva é assim e você vale o que tem / vale o que tem na mão, na mão." Vale ressaltar que o rap é um gênero musical ligado à periferia e em sua origem tratava assuntos como violência e política nas favelas de Kingstone, na Jamaica. O rap é, portanto, um gênero

22 TV Brasil ganha primeiro prêmio de jornalismo com rap-reportagem. Disponível em: <http:// www.tvbrasil.org.br/saladeimprensa/release_064.asp>. Acesso em: 4 nov. 2008.

23 Grife criada no Rio de Janeiro por prostitutas ligadas à ONG Davida. 
historicamente ligado ao protesto social, à voz do cidadão comum sobre questões que afetam diretamente a sua vida.

A matéria é a última da edição, espaço geralmente destinado a assuntos mais amenos, de menor importância ou a notícias de última hora. Como, de fato, esta não é uma notícia factual e urgente, ela é certamente colocada no lugar do ameno pelo formato pouco usual. O enquadramento da questão das prostitutas é o mais desatrelado das questões institucionais, ainda que tenha sido motivado pela iniciativa de uma organização não governamental. O aparecimento desse formato efetivamente dentro do telejornal é um primeiro indicativo de que as linguagens experimentadas pelas produções da população podem dar origem a novas formas de fazer jornalismo na TV Brasil.

É preciso reconhecer que, ainda que uma televisão pública possa ser um lugar privilegiado para a experimentação e o desenvolvimento de novos formatos, isso precisa dialogar com a história de audiência televisiva do país. Desse modo, o Repórter Brasil se utiliza de marcas consagradas no telejornalismo nacional para sugerir reconhecimento e até mesmo credibilidade. O cenário, os formatos das notícias, o tempo das matérias, a organização das editorias, o modo discreto de se comportar e se vestir dos apresentadores funcionam como um indicativo de que aquilo, efetivamente, é um telejornal. Nesse sentido, o programa reproduz estratégias textuais e discursivas já fortemente codificadas no telejornalismo brasileiro. Contudo, na tentativa de fazer um telejornal que aparente seriedade, imparcialidade e credibilidade, a TV Brasil acaba por produzir um telejornal que evolui muito pouco, tanto em relação à linguagem como em relação à inclusão do cidadão. O lugar do cidadão no telejornal é retórico, limitado à enquete ou ao quadro Outro Olhar, que sequer chegam a fazer parte do programa organicamente.

Com relação aos quatro operadores aqui analisados, observamos que a postura dos mediadores sugere imparcialidade e distanciamento da notícia pela não emissão declarada de opinião, o figurino discreto, os movimentos contidos. A isso se soma o contexto comunicativo ambientado por um cenário que mais distancia que aproxima emissor e receptor, 
embora sugira um ambiente acolhedor aos entrevistados - a bancada, por exemplo, pode marcar a diferença entre o espaço de quem produz a notícia e de quem a recebe simplesmente.

A organização das editorias privilegia o âmbito da política institucionalizada e da economia de governo, das balanças comerciais, dos incentivos à produção interna. A temática da diversidade praticamente não aparece, o cotidiano é visto como banal, ameno, relegado aos blocos finais do noticiário.

Do ponto de vista do pacto sobre o papel do jornalismo, as falas no Repórter Brasil são quase sempre declaratórias e dão conta de aspectos já legitimados das decisões de governo, das mudanças na economia, das relações internacionais e até mesmo de questões relativas às minorias. $\mathrm{O}$ cidadão não faz parte da construção da notícia, senão como exemplo de quem é afetado pelos fatos, como se estes fossem dados e regulados por decisões político-legislativas e não construídos pela engrenagem lenta e plural do cotidiano. O telejornal como espaço para a produção da opinião pública não favorece o debate e os pontos de vista apresentados ali, geralmente institucionais, não dialogam entre si, não são questionados, não há uma evidência do dissenso, da discordância ou a problematização das questões.

O caso da notícia acerca do relatório do conselho curador sobre a denúncia de Luiz Lobo exemplifica a falta de transparência e a superficialidade do Repórter Brasil na construção da notícia. É preciso considerar que a denúncia do ex-funcionário diz respeito justamente à independência da TV Brasil em relação ao governo, mas a prestação de contas da emissora para o seu público se resume a uma nota que sequer diz quem é o conselho ou com base em que dados a denúncia foi analisada. As noções de interesse público e responsabilidade social ficam certamente prejudicadas nesse contexto. A TV Brasil não vai além do que fazem as emissoras comerciais embora a sua natureza pressuponha que ela deve transparência ao público porque pertence a ele.

Iniciativas como ter um correspondente em Angola, por exemplo, pela importância dos laços históricos e culturais guardados entre Brasil e África e mesmo as relações diplomáticas que os dois países sustentam agora; 
ou noticiar matérias de interesse das minorias como no caso da união estável entre homossexuais, são certamente importantes e marcam novas possibilidades de diálogo na televisão, mas a partir do momento em que essas questões são reduzidas ao nível institucional da política feita nos gabinetes, aspectos importantes da cidadania e do cotidiano deixam de ser discutidos. Falar de cinema ou música nas escolas e não discutir as diferenças sociais e de acesso da população aos meios de produção em relação à diversidade cultural significa reproduzir sistemas hegemônicos calcados em velhas instituições, as mesmas que têm direito à fala. Não promover o debate público das questões que interessam o cidadão, sejam elas decisões de governo, ou o movimento da população em torno de uma questão, dando voz às discordâncias e possibilitando que diferentes pontos de vista sejam efetivamente apresentados, significa não reconhecer o caráter argumentativo, multicultural e plural da esfera pública contemporânea. Mesmo a construção do nacional é retórica e reproduz a tendência de tomar São Paulo, Rio de Janeiro e Brasília como exemplo genérico do que seja o Brasil, embora a maior promessa da TV Brasil fosse justamente fazer um telejornalismo nacional de fato, especialmente no telejornal de rede.

O Repórter Brasil transita entre as tentativas possíveis de reproduzir o padrão do telejornalismo comercial com um discurso sobre o cidadão que não consegue se desvincular das instituições legitimadas e legitimadoras da sua construção; e de reproduzir a visão didática própria das televisões educativas como se desenvolveram no Brasil. Entre estes dois polos, as iniciativas de ruptura e experimentação são ainda muito tímidas, não chegando a se configurar como características do jornalismo ali produzido.

O lugar do cidadão é retórico - ele não é o sujeito do discurso, mas o personagem deste. É na tentativa de transitar entre essas possibilidades que o Repórter Brasil constrói o seu modo de endereçamento, o seu estilo, convocando um público que quer se ver na tevê, mas que ainda está muito acostumado aos modos tradicionais de fazer jornalismo no Brasil, recorrendo às fontes autorizadas, construindo imparcialidade e veracidade nos formatos de apresentação da notícia, na postura do jornalista que "não opina", por exemplo. Considerando que a esfera 
pública contemporânea já não opera nos termos habermasianos - segundo os quais as mídias distraem o público da ação política -, é necessário pensá-la como um lugar de participação do público, das vozes dissidentes. As noções de esfera pública, jornalismo e interesse público pressupostos aqui não dialogam de fato com as possibilidades de uma televisão efetivamente pública.

\section{REFERÊNCIAS}

ALBUQUERQUE, Afonso de. A identidade jornalística no Brasil: algumas questões teóricas e metodológicas. E-Compós: Revista da Associação Nacional dos Programas de Pós-Graduação em Comunicação, v. 1, p. 1-14, 2004.

MARTÍN-BARBERO, Jesús. Televisão pública, televisão cultural: entre a renovação e a invenção. In: RINCÓN, Omar (Org.). Televisão pública: do consumidor ao cidadão. São Paulo: Friedrich Ebert Stiftung, 2002. p. 41-79.

BRASIL. Medida provisória n. 398, de 10 de outubro de 2007. Institui os princípios e objetivos dos serviços de radiodifusão pública explorados pelo Poder Executivo ou outorgados a entidades de sua administração indireta, autoriza o Poder Executivo a constituir a Empresa Brasil de Comunicação - EBC, e dá outras providências. Disponível em: <http://www.planalto. gov.br/ccivil_03/_Ato2007-2010/2007/Mpv/398impressao. htm> Acesso em: 01 out. 2008.

DIAS, Marina. Florestan Fernandes Jr. estréia no comando de “Repórter Brasil”. Portal Imprensa, 11 abr. 2008. Disponível em: <http://portalimprensa.uol.com.br/portal/ ultimas noticias/2008/04/11/imprensal8592.shtml>. Acesso em: 30 set. 2008.

EMPRESA BRASIL DE COMUNICAÇÃO. Outro olhar: o jornalismo feito pelo cidadão na TV Brasil. Disponível em: http://www.tvbrasil.org.br/reporterbrasil/outroolhar.asp. Acesso em: 25 out. 2008. 
FONSECA, Virgínia; LINDEMANN, Cristiane. Webjornalismo participativo: repensando algumas questões técnicas e teóricas. Revista FAMECOS, Porto Alegre, n. 34, p. 86-94, dez. 2007. GOMES, Wilson. Esfera pública política e mídia: com Habermas: contra Habermas. In: RUBIM, A.; BENTZ, I.; PINTO, M. (Org.). Produção e recepção dos sentidos mediáticos. Petrópolis: Vozes, 1998. p. 155-185.

LIVINGSTONE, Sonia M.; LUNT, Peter. Talk on television: audience participation and public debate. London; New York: Routledge, 1994.

MACEDO, Danilo. Franklin Martins elegia proposta de recursos para a EBC. Agência Brasil, 26 fev. 2008. Disponível em: <http://www.agenciabrasil.gov.br/noticias/2008/02/ 26/ materia.2008-02-26.4751322415/view >. Acesso em: 01 out. 2008.

MACEDO, Danilo. Cidadão vai poder opinar sobre a programação da TV Brasil. Agência Brasil, 02 dez. 2007. Disponível em: <http: / /agenciabrasil.ebc.com.br/arquivo/ node/341861? page=1>. Acesso em: 10 fev. 2011.

MARTÍN-BARBERO, Jesús ,ORTIZ, Renato. A moderna tradição brasileira: cultura brasileira e indústria cultural. São Paulo: Brasiliense, 2006.

RACIONAIS MC's. 1 por amor, 2 por dinheiro. In: .100 trutas, sem tretas. São Paulo: RDS Fonográfica, p2006. 1 DVD, faixa 10 .

SOALHEIRO, Marco Antônio. Repórter Brasil inaugura jornalismo unificado da TV Brasil. Agência Brasil, 03 dez. 2007. Disponível em: <http://www.agenciabrasil.gov.br/ noticias/2007/11/30/materia.2007-11-30.4143275408/view>. Acesso em: 03 nov. 2008. 
TV BRASIL: preparação do novo jornal, 2007. Disponível em: <http:/ / br.youtube.com/watch? v=M-YorpsQ3kU>. Acesso em: 20 out. 2008. 



\title{
O grito da cidade: Balanço Geral, qualidade e modos de endereçamento
}

Janira Borja

\author{
Discutir televisão hoje no Brasil significa tratar \\ de nada menos que o próprio espaço público. \\ É dessa forma que a pergunta 'Por que falar de televisão?' \\ deve começar a ser respondida
}

Eugênio Bucci

\section{INTRODUÇÃO}

Imagens do caos urbano, criminalidade e o descaso dos serviços públicos inundam o telejornalismo do horário do meio-dia. Por todo o Brasil, programas de grande apelo popular, anunciam a "voz do povo" e prometem olho vivo para os problemas vividos pela parcela mais pobre da população. O Balanço Geral veiculado pela TV Itapoan (retransmissora da TV Record na Bahia) às 11h45min, de segunda a sexta-feira, é um exemplo desse tipo de telejornal. No seu site, ele é descrito como

[...] o programa (que) mostra a realidade e a opinião dos baianos na TV, além das principais notícias do dia em todo o estado. Com um forte compromisso com a comunidade local, o Balanço Geral expressa e faz valer a voz do povo. A verdade. Doa a quem doer. (BALANÇO GERAL, [20--?])

Geralmente, a análise desses programas baseia-se em critérios éticos, morais e políticos, versando sobre a tendência a adotar um discurso simplista e conservador, a superficialidade da sua cobertura, ou sua atuação como mídia-tribunal, sentenciando fatos e pessoas que ainda não foram julgados pelos trâmites legais. Mas poucos estudiosos dedicam-se a compreender a construção interna desses programas e como eles estabelecem sua relação com o espectador. Dessa forma, o 
mecanismo de funcionamento (e, às vezes, de sucesso) desses programas continua desconhecido para a maioria dos pesquisadores de comunicação.

Autores como Freire Filho (2004), Cunha (2005) e Machado (2000) apontam para uma carência de análises de televisão baseadas em critérios que sejam inerentes à lógica da própria mídia, constituindo estudos que se voltem realmente para a produção televisiva contemporânea. Dessa forma, os operadores de análise construídos pelo Grupo de Pesquisa Análise de Telejornalismo funcionam como importante ferramenta analítica que nos permite olhar para a produção jornalística efetiva, possibilitando a construção de critérios, vocabulários e categorias de pesquisa intrínsecos à televisão.

\section{É POSSÍVEL FALAR DE UMA QUALIDADE INTERNA \\ DO PRODUTO TELEVISIVO?}

Com a análise do Jornal do SBT ${ }^{1}$ pelo Grupo de Pesquisa Análise de Telejornalismo, aplicando os operadores e discutindo os resultados nas reuniões da equipe, chegou-se à conclusão que o telejornal sofria de uma espécie de "desajuste dos modos de endereçamento". Não havia um encaixe entre a proposta do Jornal do SBT e sua configuração interna. O resultado era um programa que, para além das propostas éticas ou políticas, não funcionava internamente.

Daí abriu-se a possibilidade de análise da qualidade de um programa jornalístico a partir do exame dos modos de endereçamento, utilizando os operadores desenvolvidos no Grupo. Esse artigo é um exercício de verificação da funcionalidade desses operadores para o estudo da qualidade de programas televisivos. A proposta desta análise não é discutir a qualidade ética ou política do Balanço Geral. Buscamos certo ‘ajuste’ interno, perceber se o telejornal funciona a partir das categorias do próprio programa em relação ao que se propõe. Discutir sua qualidade como produto desta linguagem, sem precisar recorrer a critérios externos ao suporte televisivo.

1 Resultados dessa análise foram apresentados no artigo de Gomes e outros (2004). 
A análise dos modos de endereçamento permite examinar o 'estilo', que diz respeito à forma como cada programa articula e combina os elementos do gênero para constituir uma marca própria e instaurar sua relação com a audiência. Se os modos de endereçamento operam com os elementos do gênero, uma análise deles implica numa análise interna do produto, embora elementos extratextuais que sejam importantes para o entendimento do programa possam ser levados em conta ao longo do percurso analítico. Apesar da análise de modos de endereçamento possibilitar essa ida fora do texto, é importante ressaltar que nos interessa o texto em si, o programa, sua configuração e estruturação interna. E é justamente nessa opção que reside a principal contribuição desse trabalho, ajudando a pensar televisão a partir de suas próprias pistas, critérios e linguagem. A análise da qualidade a partir dos modos de endereçamento responderá a perguntas como: o telejornal consegue ajustar sua proposta com a conformação interna dos elementos de modo a estabelecer relação com seu telespectador? Os modos de endereçamento, que dizem dessa relação com a audiência, funcionam de modo satisfatório, ou seja, ele consegue utilizar corretamente os elementos da linguagem televisiva e do gênero jornalístico a fim de atrair esse telespectador?

O termo qualidade pode ser utilizado para uma grande variedade de acepções, que vão desde abordagens técnicas à defesa de valores moralistas na televisão (inclusive como querem muitos movimentos da sociedade civil). Geoff Mulgan (1990 apud MACHADO, 2000) enumera sete diferentes sentidos para a palavra qualidade: 1) capacidade de usar os recursos expressivos do meio; 2) capacidade de satisfazer necessidades da audiência e da sociedade; 3) competência para usar os recursos de linguagem de uma forma inovadora; 4) promoção de valores morais e modelos edificantes e construtivos de conduta; 5) capacidade de gerar mobilização e participação nacional em torno de grandes temas de interesse coletivo; 6) promoção de uma programação que valorize as diferenças, as minorias e as individualidades; 7) diversidade, capacidade de abrigar a maior quantidade de experiências diferenciadas. Todas essas acepções estão corretas e se prestam aos mais diferentes contextos. Por exemplo, os políticos costumam abordar qualidade de TV como a ca- 
pacidade de gerar comoção nacional (5), enquanto que a abordagem dos estrategistas de marketing sobre o que seria 'qualidade' na TV é, principalmente, a capacidade do meio de detectar as demandas da população e transformá-las em produto (2). Por isso, Machado (2000, p. 25) propõe que o conceito de qualidade utilizado para a televisão deve ser elástico e complexo de modo que

[.... permita valorizar trabalhos nos quais os constrangimentos industriais (velocidade e estandardização da produção) não sejam esmagadoramente conflitantes com a inovação e a criação de alternativas diferenciadas, nos quais a liberdade de expressão dos criadores não seja totalmente avessa às demandas da audiência.

Sendo uma instituição social (WILLIAMS, 1997), o jornalismo é resultado de possibilidades técnicas e de uma conjunção histórica, econômica, social e cultural particular. Dessa forma, a noção de qualidade telejornalística também muda com as diferentes sociedades e culturas. Por isso, essas assunções sobre a qualidade de um telejornal devem sempre levar em conta para qual público se dirige, em qual sociedade atua, qual o papel do jornalismo implicado no programa e, principalmente, devem estar sempre relacionadas a critérios expressos.

Existirão tantos jornalismos quantas são as culturas, as sociedades e os tempos históricos em que ele é praticado e o trabalho do analista é encontrar as marcas da sua heterogeneidade constitutiva. (GOMES; GUTMANN; SANTOS 2008, p. 4)

O GRITO DA CIDADE NO BALANÇO GERAL

É o pedido de socorro. É o grito da cidade. É o Balanço Geral Raimundo Varela

Foram analisadas 10 edições do telejornal, de 12 a 23 de setembro de 2003. Cada uma delas tem cerca de 1h15min de duração, divididas em quatro blocos. As matérias são alternadas com leituras de fax e e- mails enviados pelos telespectadores, e comentários do apresentador. 
O programa de sexta-feira tem uma estrutura um pouco diferenciada, com presença de um auditório formado por alunos da rede pública de ensino, que participam "ao vivo", fazendo perguntas ao entrevistado. Podem participar também grupos de música, como convidados do programa.

Os nove operadores de análise - mediador; pacto sobre o papel do jornalismo; temática, organização das editorias e proximidade com a audiência; contexto comunicativo; texto verbal; recursos técnicos a serviço do jornalismo; recursos da linguagem televisiva; formatos de apresentação da notícia; relação com as fontes de informação - foram utilizados, nesse trabalho, de forma articulada e não separadamente. O objetivo era permitir que o próprio programa desenhasse uma hierarquia de importância dos operadores para a análise, resultando numa aplicação específica da proposta metodológica. No nosso estudo, cinco operadores tiveram atuação destacada para o entendimento do programa analisado e, a partir desses, todos os outros foram se articulando. São eles: o mediador, o contexto comunicativo, o texto verbal, temática, organização das editorias e proximidade com a audiência e o pacto sobre o papel do jornalismo.

"CÂMERA EM MIM AGORA..."

- O PAPEL DO MEDIADOR NO BALANÇO GERAL

O mediador foi o principal elemento de análise, já que é a partir dele que o programa se estrutura. Raimundo Varela atua como condutor do telejornal, é na sua figura e no que ele tem a dizer que está a principal característica do programa. O apresentador determina, muitas vezes verbalmente, durante o programa, para qual câmera quer falar, que notícia quer veicular primeiro, demonstrando sua posição destacada na condução do telejornal. Mais do que expor os fatos, Varela seleciona, diz quando o espectador deve prestar atenção, valora e julga as notícias veiculadas.

A utilização dos cartões vermelho e verde, uma das marcas do programa, é uma forma de classificar as notícias veiculadas entre boas e ruins, apresentando a opinião do apresentador sobre os fatos, elemento central de caracterização do Balanço Geral. 
Popularmente, o telejornal é conhecido como Programa do Varela. $\mathrm{O}$ apresentador reforça esse destaque, ao utilizar sempre a primeira pessoa do singular para se referir ao programa, e ao explicitar verbalmente sua condição de fio condutor, ao determinar, no ar, qual notícia vai ser veiculada primeiro, para qual câmera quer falar: "Eu quero ouvir o povo, Edmundo!"2; "Por favor, por favor, eu quero a matéria de Severino, por favor. Eu preciso colocar essa matéria pro povo entender a gravidade disso"3. "Me mostra imagens, por favor, do Iguatemi, é possível? Cadê o Edmundo? Edmundo já está OK? Não, Iguatemi, eu quero do Iguatemi."”, "Daqui a pouco eu quero falar com Edmundo Filho, quando ele tiver OK me avisa, hein?" 5 .

O envolvimento emocional de Varela com os fatos noticiados é uma importante estratégia de construção de identificação com o telespectador. Ironia, raiva, indignação, alegria são constantemente expressados pelo apresentador durante suas opiniões, através tanto do texto verbal, quanto da modalização da voz, gestos faciais e expressão corporal. A atitude enérgica, materializada no tom de voz alto e forte, no gesto de bater na mesa e na expressão clara dos sentimentos de Varela potencializam o efeito emocional do seu discurso, humanizando-o e aproximando-o do telespectador.

"Você vai ler jornal, toma cada susto! Você já viu um canal de drenagem custar 13 milhões? 13 milhões de reais! (aumenta tom de voz) Sabe o que é isso? 13 milhões!!". Sobre aumento da gasolina, Varela se indigna: "Tem posto na Bahia vendendo a 2,80 o litro já (bate 3 vezes na mesa, sobe música) Que ganância é essa? (bate mais uma vez) Ah, mas os preços não são controlados. E daí metem a mão!??? ${ }^{6}$. O discurso do apresentador já nos leva à análise de outro operador, o texto verbal. No programa analisado, esse operador é importante elemento de caracteri-

2 Programa exibido em 21 de setembro de 2005.

3 Programa exibido em 22 de setembro de 2005.

4 Programa exibido em 16 de setembro de 2005.

5 Programa exibido em 19 de setembro de 2005.

6 Programa exibido em 12 de setembro de 2005. 
zação, já que a opinião e a fala do apresentador possuem tanto destaque. O discurso do mediador se caracteriza, em linhas gerais, como opinativo, valorativo e orientador. Ele seleciona os fatos, aponta e julga. Elementos do discurso populista ${ }^{7}$ também caracterizam, de forma generalizada, a fala do mediador: conservadorismo, maniqueísmo, paternalismo e apelo emocional. Varela se apropria e manuseia de forma competente e proveitosa esses elementos, que funcionam como ganchos para atrair e conquistar esse telespectador. A simplificação do mundo em dois polos (bom VS. maus, justos VS. injustos, certo VS. errado) e a escolha clara por um deles (o bom, justo, certo) está sempre conectada a uma divisão social entre ricos VS. pobres. Aos primeiros, sempre é relegado o papel do mau, explorador e desonesto. Varela se coloca estrategicamente do lado "bom" (e faz isso de forma pedagógica), do pobre, que é o telespectador-textual do seu programa. E deixa clara a opção do programa verbalmente: "Na avenida Garibaldi o tratamento é um, o povo na periferia é outro. Mas esse é um programa popular, de participação popular. Olha, me deixe, viu. Me deixe!”8, "A gente tem que priorizar o povo, hein?”9.

"Mas garanto que o filho dela e o filho do rico não ficam sem professor" 10 - Varela se refere à Secretária de Educação, depois de denúncia de falta de professor em escola.

Os cartões verde e vermelho, que Raimundo Varela utiliza para parabenizar ou criticar determinada notícia, autoridade ou fato, funcionam como uma materialização desse discurso maniqueísta.

7 O populismo, no Brasil, está relacionado com as mudanças políticas e econômicas acontecidas no país no período que se estende de 1930 a 1946. Com a queda de poder das oligarquias, não havia nenhuma força social capaz de sustentar uma nova estrutura do Estado. "Nessa situação, a única fonte de legitimidade dessa nova estrutura serão as massas populares urbanas". (MELO, 1981, p. 18) No populismo, questões essencialmente políticas e sociais são avaliadas em termos de valores éticos e o poder confunde-se com o chefe que o exerce, assumindo uma forma 'pessoal'. (MELO, 1981) Para angariar o apoio e a legitimação das classes populares, o discurso dos chefes políticos considerados populistas reunia alguns elementos similares, que acabaram por configurar certo 'discurso populista', caracterizado, principalmente, pelo paternalismo, o apelo emocional, o maniqueísmo e a busca de identificação popular.

8 Programa exibido em 21 de setembro de 2005.

9 Programa exibido em 19 de setembro de 2005.

10 Programa exibido em 12 de setembro de 2005. 
Expressões como "fique ligado"11, "não mexa no televisor"12, "Daqui a pouco a vovó simpatia, heim! Você não pode perder!"13 são utilizadas para acionar a atenção do telespectador, reforçando essa relação com a audiência. Muitas vezes, Varela dirige-se diretamente a um telespectador, respondendo a um fax ou e-mail: "Esse é o meu time, viu, George, para nunca mais você ter dúvidas"14.

Eliseo Verón (1983) classifica os apresentadores em "apresentador-ventríloquo" e "apresentador moderno" ou "meta-enunciador", baseado na gestualidade e no posicionamento diante das câmeras. O "apresentador-ventríloquo" é aquele que funciona como ponto de passagem do discurso, caracterizado pelo factual e pelo descritivo. Seus gestos são mínimos e o olhar é a única forma de contato com o telespectador. Já com o "meta-enunciador", expande-se a dimensão corporal e todo o corpo é mediatizado na relação com o telespectador. Parece claro que Varela não se encaixa na primeira categoria, todo o seu "corpo visível” participa do enunciado e ajuda na construção do sentido do que é dito. Além dos gestos, o apresentador modaliza o discurso também através da entonação da voz.

Mas ele também não se enquadra na segunda categoria, porque apesar de todo o gestual empregado, os enquadramentos são bastante tradicionais. Varela é mostrado sempre num Plano Americano (PA), dos cotovelos para cima, mostrando parte da bancada na qual se apoia. Toda a dimensão corporal está restrita aos braços, mãos e rosto. No caso do meta-enunciador, Verón diz que a expansão do "corpo mediatizado" (VERÓN, 1983, p. 13) vem acompanhada de uma expansão do cenário, que ganha profundidade e arquitetura e uma maior variedade de movimentos de câmera.

Devido à inexistência de modelos adequados, propomos o "apresentador ator". Este se situaria entre o "apresentador intérprete" (GOMES

11 Programa exibido em 12 de setembro de 2005.

12 Programa exibido em 15 de setembro de 2005.

13 Programa exibido em 13 de setembro de 2005.

14 Programa exibido em 13 de setembro de 2005. 
et al., 2005), categoria criada pelo Grupo de Pesquisa Análise de Telejornalismo para designar aquele mediador que interpreta o texto através de gestos faciais e modalização da voz de forma discreta (exemplo desse modelo é o casal de apresentadores do Jornal Nacional: Fátima Bernardes e William Bonner) e "meta-enunciador". No caso do "apresentador ator", o corpo participa mais da interpretação da fala, embora essa dimensão não se expanda com a multiplicação de cenários e enquadramentos.

Na edição de 15 de setembro de 2005, depois de ler um fax de um morador de Itaparica, reclamando da situação da ilha, Varela comenta:

Quem tem sua dor é que geme, viu, amigo [bate na mesa]. Agora no palanque [aponta o dedo para trás], tinha até Bel do Chiclete [simula que está tocando uma guitarra com as mãos e balança o corpo]. Taran-ran-tan-tan-tam-taram [simula a 'música']. [Bate na mesa e gira a mão direita]. Mil promessas e nada faz um gesto de 'banana' com o braço direito]. Nada pro povo.

"AO LADO DO POVO..."

- APROXIMAÇÕES E DISTANCIAMENTOS NO DISCURSO DE VARELA

Raimundo Varela constrói para si um lugar de enunciação que o situa "ao lado do povo", como dito anteriormente, numa tentativa de identificá-lo com o telespectador. No seu discurso, ele se coloca como um cidadão comum, sofredor das mazelas urbanas e revoltado com os escândalos políticos.

Raimundo Varela - Eu tenho raiva quando eu recebo uma conta atrasada. Esse mês passado eu recebi uma conta pra pagar no dia 5, chegou na minha casa no dia 5 de manha. Peraê! Aí foi o Correio que atrasou. Agora, estamos em greve nos correios. E agora? Como é que a carta vai chegar? Não é? Imagine que situação! ${ }^{15}$

Raimundo Varela - "A gente já 'tá' cansado disso. O povo já não aguenta mais"16.

15 Balanço Gral, programa exibido em 16 de setembro de 2005.

16 Balanço Gral, programa exibido em 16 de setembro de 2005. 
Essa identificação muitas vezes é reforçada através da forma de falar. Raimundo Varela utiliza uma linguagem coloquial recheada de expressões populares e tenta sempre criar um clima de despojamento no seu discurso. Dessa forma, o comentário soa mais naturalizado, inserido no mundo do telespectador:

Raimundo Varela - Pergunta se o povo sabe disso!! Ninguém sabe, só os deputados. E ficam lá fingindo que não sabem! Oh, me deixe, viu! Me deixe, viu! 'Tô' ficando careca! Ó minha cabeça ó (mostra as entradas na cabeça sem cabelo), 'tá' ficando careca!17

Porém, ao mesmo tempo em que Varela simula essa dimensão de compartilhamento com o público, outras estratégias apontam para um distanciamento que o autoriza a selecionar, classificar e valorar os acontecimentos do mundo. Seu discurso é marcado por um jogo de aproximações e distanciamentos, que lhe permite colocar-se ao lado do povo em determinados momentos e acima dele, quando necessário. Cabe ao programa o papel de oferecer esse espaço de contato entre o público e o poder. Sendo assim, já não mais se localiza ao lado do povo, mas acima dele. Preocupado com as questões populares, mas com poder suficiente para acionar as instituições públicas, retratadas sempre como distanciadas da parcela mais pobre da população. Nesse momento o programa adquire um cunho paternalista. É Raimundo Varela que nos mostra as pistas para entender o contexto comunicativo proposto pelo programa:

Raimundo Varela - O Balanço Geral não faz nada não. Agora, nós queremos ser o que? Nós queremos ser o elo de ligação, o elo de ligação entre você e o poder. Calabetão. Olha a situação da rua, heim. É o pedido de socorro. É o grito da cidade. É o Balanço Geral [...]. São os bairros da periferia pedindo socorro através do Balanço Geral $^{18}$.

Esse distanciamento é materializado também por uma postura pedagógica do apresentador, que se apresenta como aquele que traz e explica

17 Balanço Geral, programa exibido em 23 de setembro de 2005.

18 Balanço Geral, programa exibido em 13 de setembro de 2005. 
as informações do mundo para o cotidiano da população. Fatos do mundo político e do poder são "traduzidos" para o idioma popular, além de veiculados sempre a partir do ponto de vista das consequências no dia a dia do cidadão. Raimundo Varela atua como aquele que oferece o espaço, explica as notícias e orienta a população. Operadores didáticos como a repetição da informação são constantemente utilizados para simplificar a mensagem e facilitar o entendimento por parte do telespectador.

Raimundo Varela - Você deve procurar a corregedoria da polícia, a ouvidoria da polícia e fazer uma queixa. A cor-re-ge-do-ria (fala de forma mais devagar, dando ênfase nas sílabas) de polícia é o órgão que fiscaliza a ação praticada por policiais, como tem a cor-re-ge-do-ria de justiça, que fiscaliza as ações dos juízes. Imagine! Então cabe às famílias se unirem e irem até a ouvidoria e corregedoria da polícia e colocar essa situação para que chegue ao conhecimento das autoridades ${ }^{19}$.

Essa postura assumida pelo apresentador (e pelo programa como um todo) no sentido de diferenciá-lo do telespectador, adotando uma posição superior de quem ensina e orienta, fica explícita também quando Varela conduz o programa de modo a guiar a audiência, dizendo em quais momentos o telespectador deve prestar mais atenção, quando deve se indignar, quais notícias são chocantes. Para isso, ele utiliza muitos operadores de interpelação e verbos no imperativo: "Observem. O trânsito parou aqui em frente, hein, no viaduto Raul Seixas. Observem”20.

Raimundo Varela - Rapaz, eu não sei nem por onde começar. Preste atenção, viu, Ricardo. A pergunta que eu vou fazer agora eu quero você de casa atento ao que eu vou dizer: onde está o limite da violência no Brasil? Não tem. Ultrapassamos ontem o limite. Eu confesso que eu já tenho 30 anos no rádio e na televisão, eu nunca vi um negócio desses que nós vamos ver agora. Foi o maior crime que eu já vi na televisão. [...] $]^{21}$.

19 Balanço Geral, programa exibido em 13 de setembro de 2005.

20 Balanço Geral, programa exibido em 12 de setembro de 2005.

21 Balanço Geral, programa exibido em 12 de setembro de 2005. 
Há um lastro simbólico no qual o discurso de Varela se sustenta, construído durante todo o seu trajeto no campo jornalístico, reconhecido pelo telespectador. Além disso, essa trajetória é sempre citada na sua fala, como forma de inseri-la textualmente no programa, além de autorizar e credibilizar as opiniões emitidas.

A vestimenta do apresentador, que sempre está de terno e gravata, emprestam seriedade à sua figura, ajudando a reforçar a sua imagem como aquele autorizado a orientar e representar o telespectador.

"VOCÊ DE CARA COM A VERDADE..."

- O TELESPECTADOR TEXTUAL NO BALANÇO GERAL

Se o programa, em especial seu apresentador (que é a encarnação física das características pretendidas pelo Balanço Geral), constrói para si esse lugar ambíguo que se desloca do lado do cidadão, num patamar de igualdade, para aquele lugar de porta-voz dos anseios do povo, orientando, explicando e guiando o telespectador, ele constrói também um lugar para esse telespectador. No Balanço Geral, a audiência (e aqui já falamos do operador contexto comunicativo) está caracterizada como aquele cidadão pobre, desassistido, morador da região periférica da cidade ("cidade simbólica” construída pelos programas), que sofre com problemas como falta de infraestrutura urbana e carência de serviços públicos. Esse telespectador é retratado como distanciado do poder público, necessitando do programa (que assume o lugar de porta-voz) para atingi-lo. Destituído do seu poder de ação, a população estaria à mercê das autoridades públicas para a resolução dos seus problemas e, em boa medida, dos telejornais, já que esses atuam como o elo entre essas duas instâncias.

O Pátio do Povo, quadro no qual a população entra "ao vivo" no programa para fazer suas reclamações e apelos, é um dos melhores exemplos desse lugar oferecido ao telespectador no contexto comunicativo proposto pelo programa.

Repórter - Varela, olha só a expressão de D. Jacira [...] Ela vai ser encaminhada aqui através Balanço Geral para a delegacia porque estava muito nervosa e depois do roubo não conseguiu registrar queixa e pede que você, através do Balanço Geral, peça com maior 
brevidade a solução desse problema. O nome dela é Jacira das Virgens Ramos, ela foi roubada ${ }^{22}$.

No Balanço Geral, todo esse universo excluído (e aqui já falamos também de temática, organização das editorias e proximidade com a audiência) para o qual o programa se dirige está presente no programa, desde os assuntos tratados, abordagens das matérias, territórios acionados. O telejornal aciona uma determinada cidade simbólica constituída pela periferia da cidade, palco das maiorias das notícias veiculadas. Assuntos ligados a esse sentido de localidade (e principalmente a essa cidade) como buracos nas ruas, bandidos presos, aumento de tarifa dos transportes, falta de professor na escola são os mais característicos da cobertura feita pelo telejornal.

"É O GRITO DA CIDADE!" - JORNALISMO E POVO NO BALANÇO GERAL

A presença da audiência no programa, seja fisicamente ou como estratégia textual, e a forte ligação do jornalismo com certo sentido de vigilância e localidade são outras importantes características do Balanço Geral.

Existe um telefone específico para denúncias, o Disque-denúncia, e todos os dias um quadro especial coloca no ar a reclamação de um cidadão, geralmente no início do segundo bloco. A denúncia e a abertura do espaço para o povo estruturam e caracterizam o programa Balanço Geral. Durante todo o telejornal, Varela lê fax e e-mails enviados por telespectadores de todo o Estado fazendo reclamações sobre assuntos relacionados aos poderes públicos e ao dia a dia de uma cidade: infraestrutura urbana, saúde, educação, segurança pública, emprego.

O "povo fala”, estratégia utilizada para autenticar a cobertura de um assunto e servir de ponto de identificação para o receptor, está presente em todo o programa. Além das formas de contato com o telejornal: telefone, fax e e-mail, o programa traz também o Pátio do Povo. O segundo bloco sempre inicia com o quadro Disque denúncia com as denúncias apuradas através do telefone e o terceiro bloco com o quadro Me deixe, viu!, 
espaço onde o povo pode fazer uma queixa ou reclamação de uma forma mais divertida terminando com o bordão "Me deixe, viu!", expressão tipicamente soteropolitana. Além disso, a abordagem preferencial das matérias é sobre as consequências do fato noticiado para a vida do cidadão comum.

O pacto sobre o papel do jornalismo que melhor funciona aqui é o da vigilância, que determina um jornalismo sempre alerta para descobrir e noticiar fatos contrários aos interesses do povo. Essa opção é constantemente reiterada no programa como estratégia de credibilidade.

A cobertura do Balanço Geral é essencialmente local (Salvador): tarifa de ônibus, ruas esburacadas, falta de iluminação pública etc. Fatos da cidade são a principal matéria-prima do programa. Quando entram matérias nacionais, estas dizem respeito, principalmente, a acontecimentos políticos que interferem na vida de todo o país, como no caso da matéria sobre a cassação de Severino Cavalcanti, ex-presidente da Câmara Federall $^{23}$, e que trazem repercussões para o cidadão baiano.

A cidade que pede socorro, excluída da esfera de ação do poder público é matéria-prima do jornal que sempre afirma mostrar a "verdade nua e crua", de pobreza, miséria e necessidade do povo baiano. Assim, o pacto sobre o papel do jornalismo é reforçado como aquele que, além de vigiar e denunciar todos os fatos contrários aos interesses da população e intervir a favor do povo, traz à tona notícias normalmente postas de lado pela imprensa tradicional ou veiculadas somente nas páginas policiais.

Edmundo Filho - Ao lado do povo, Varela, para mostrar a vida como ela é. Sem retoques e sem maquiagem (câmera faz movimento de zoom in e se aproxima do repórter, focalizando-o num close) você de cara com a verdade no Balanço Geral ${ }^{24}$.

No Balanço Geral, essa vigilância é estendida aos poderes públicos, instituições e políticos, sempre na mira dos comentários de Raimundo Varela.

23 Balanço geral, programa exibido em 22 de outubro de 2005.

24 Balanço Geral, programa exibido em 13 de setembro de 2005. 
Raimundo Varela - Outra coisa que eu queria cobrar do prefeito João Henrique, aproveitando a audiência do Balanço Geral. O prefeito João Henrique em campanha, todo mundo sabe que ele prometeu o vale transporte do trabalhador desempregado. Cadê? Cadê? $\left[\ldots . .{ }^{25}\right.$.

Essa vocação popular pretendida e divulgada pelo programa é materializada não só pela presença física do cidadão no programa através dos canais de comunicação disponíveis e dos inúmeros quadros onde a população tem espaço para falar, como também pela forma como esse cidadão é mostrado, sempre identificado com nome e sobrenome.

Os entrevistados são constantes no programa, participando de todas as edições do período analisado, exceto no dia 21 de setembro de 2005. A maioria dos convidados tem relação com os poderes públicos e geralmente é abordada sob duas perspectivas: a da vigilância ("o que a instituição anda fazendo?”) e do jornalismo de serviço (informações úteis para o dia a dia do povo).

A análise dos operadores como recursos técnicos a serviço do jornalismo e recursos da linguagem televisiva é importante para perceber como eles são usados na configuração de outros operadores como o pacto sobre o papel do jornalismo, caracterização do mediador e texto verbal.

Os dois recursos mais importantes no programa são os efeitos sonoros e o "ao vivo". Os primeiros são constantemente utilizados durante o programa e ajudam na construção de sentido do discurso do mediador, intensificando o clima de denúncia, ou revolta, ironia etc. Exemplo disso é a edição de 22 de setembro. Depois de veicular matéria sobre a confusão durante ato de renúncia de Severino Cavalcanti, ex-presidente da Câmara, Varela faz o seguinte comentário, em tom irônico: "Continuar assim, eu vou lançar o nosso Popó deputado federal (entra efeito de risadas no fundo, bate na mesa). É o nosso campeão mundial de boxe para deputado”.

O "ao vivo" é outro recurso da linguagem televisiva bastante explorado pelo Balanço Geral. Todo o programa é veiculado "ao vivo", o que empresta um sentido de verdade e credibilidade ao que é noticiado, já que pode ser atestado com imagens. Além disso, a sensação de ausência

25 Balanço Geral, programa exibido em 12 de setembro de 2005. 
de mediação também ajuda a tornar o discurso mais credível. O apresentador reforça o clima do "ao vivo" ao pedir matérias, referir-se à sua produção no ar, desnudando a produção noticiosa para o telespectador: "Cadê o Duda? O Duda já chegou? Já tem o Duda? Já posso chamar o Duda Mendonça? Chamo logo essa?”26. "Daqui a pouco eu quero falar com Edmundo Filho, quando ele tiver OK me avisa, hein! A gente tem que priorizar o povo, hein! A gente tem que priorizar o povo, hein! Já 'tá' OK Edmundo?" 27 .

O "ao vivo" é tão importante no Balanço Geral que algumas matérias tentam criar esse efeito, ao acompanhar a ação do Grupo Especial de Repressão a Roubos em Coletivos da Polícia na edição de 12 de setembro de 2005 e da Operação Visão Noturna, grupo especial da Polícia Civil para combate a furtos e roubos de veículos, na edição de 22 de setembro. Nas duas matérias, a câmera acompanha o carro da polícia, da perspectiva do motorista, colocando o telespectador como mais um naquela expedição. Durante a matéria, podemos ouvir o som ambiente, o rádio de transmissão, com o som da polícia descrevendo os suspeitos, elementos que criam um sentido de falta de mediação, como se estivéssemos acompanhando todos os passos dos policiais.

\section{(IN)CONCLUSÕES}

Nesse momento parece oportuno retomar as discussões sobre televisão e qualidade levantadas no início desse artigo. Machado (2000) cita a questão do desconhecimento da televisão devido à falta de análises da sua produção televisiva e propõe um "repertório fundamental”, um conjunto de programas que serviriam de exemplo de qualidade televisiva. Uma importante questão para Machado é o combate à ideia de que o meio televisivo por sua natureza industrial e massificadora não comporta conteúdos de qualidade estética e artística. Para tanto, ele aponta seu "repertório fundamental". O problema aqui está no fato de que os programas que constituem esse repertório são completamente deslocados

26 Balanço Geral, programa exibido em 14 de setembro de 2005.

27 Balanço Geral, programa exibido em 19 de setembro de 2005. 
da realidade televisiva contemporânea. O resultado é que caímos mais uma vez numa perspectiva do tipo "o que a TV poderia ser em termos de estética...", além de analisarmos a real produção televisiva (como havia sido a proposta do livro de Machado).

Para Freire Filho (2004) e Cunha (2005) o problema da discussão de qualidade na TV está na conformação de um conjunto de critérios internos de análise, ou seja, que estejam baseados na própria linguagem televisiva. A proposta aqui é abandonar as análises qualitativas baseadas em critérios externos (como moral, ética, política etc.), e buscar no próprio programa os referenciais para sua crítica. Além disso, a variabilidade de acepções a que se presta o conceito de qualidade (que é um valor determinado por referências sociais) implica em análises baseadas em critérios expressos e determinados.

A proposta de utilização do conceito de modos de endereçamento para análise da qualidade televisiva mostrou-se proveitosa exatamente para dar conta dessa necessidade de constituição de critérios de análise internos à lógica televisiva. A utilização do conceito de modos de endereçamento na perspectiva do "estilo" ajuda a pensar como os programas se conformam internamente, como "funcionam".

Além disso, como a proposta metodológica utilizada por esse trabalho volta-se para os produtos televisivos (no caso específico, os programas jornalísticos), pensamos a televisão "[...] como o conjunto de trabalhos audiovisuais (variados, desiguais, contraditórios) que a constituem". (MACHADO, 2000, p. 19)

Porém, apesar dos ganhos possibilitados pela análise da qualidade baseada no conceito de modos de endereçamento, essa escolha implica também limitações e problemas encontrados no percurso analítico.

A primeira e mais importante dessas limitações tem a ver com a questão: que tipo de qualidade é possível pensar a partir dos modos de endereçamento? Vamos retomar Geoff Mulgan (1990 apud MACHADO, 2000), para enumerar os sete diferentes sentidos para a palavra qualidade: 1) capacidade de usar os recursos expressivos do meio; 2) capacidade de satisfazer necessidades da audiência e da sociedade; 3) competência para usar os recursos de linguagem de uma forma inovadora; 4) promoção de 
valores morais e modelos edificantes e construtivos de conduta; 5) capacidade de gerar mobilização e participação nacional em torno de grandes temas de interesse coletivo; 6) promoção de uma programação que valorize as diferenças, as minorias e as individualidades; 7) diversidade, capacidade de abrigar a maior quantidade de experiências diferenciadas.

Sob o ponto de vista da concepção 3, por exemplo, que diz da competência para usar os recursos de linguagem de uma forma inovadora, a análise do Balanço Geral aponta para uma classificação do telejornal como tradicional no uso dos recursos da linguagem televisiva (enquadramentos repetitivos e padronizados, por exemplo). Sob o ponto de vista dos valores éticos, existe uma forte tendência em classificá-lo também como ruim, pela adoção de um discurso simplista e conservador, atuando como mídia-tribunal, sentenciando fatos e pessoas que ainda não foram julgados pelos trâmites legais.

Portanto, é necessário deixar claras as limitações de uma análise de qualidade desse tipo, já que essa é uma palavra que se presta a acepções tão variadas e conceitos tão elásticos. Interessa-nos aqui uma qualidade específica, aquela que diz respeito à forma como um programa utiliza os elementos do gênero para conformar seu estilo e estabelecer relação com seu telespectador.

Ao adotar o ponto de vista dos modos de endereçamento para pensar a qualidade, corremos o risco de cair numa perspectiva de qualidade baseada em princípios como "tudo que nós (audiência) gostamos é válido" ou "tudo que nos é proposto vale". Numa análise desse tipo, se o programa funciona, ou seja, se ele sabe para qual público se dirige e como utilizar as estratégias para capturar esse público, já pode ser considerado um programa de qualidade, ainda que seja completamente desprezível sob outros aspectos (moral, ético, político, ideológico etc.). Por isso a necessidade de ressaltar a importância de outras perspectivas para a análise da qualidade televisiva e ainda um possível cruzamento de análises que possibilite afirmações mais abrangentes sobre a qualidade de um programa.

Durante a análise dos programas, em especial dos mediadores, percebemos que um ponto chave estava na sua atuação dentro do programa, além das estratégias argumentativas: forma como encarna seu persona- 
gem, quais são e como utiliza as estratégias para ser credível (para realmente parecer indignado, revoltado, triste, alegre, preocupado com o aumento da gasolina etc.). Estratégias que têm a ver com a entonação da voz, a utilização das expressões faciais e gestos para a construção desse personagem. Nesse momento, percebemos nossa limitação na análise de dados como esse. A proposta metodológica do Grupo de Pesquisa Análise de Telejornalismo ainda não nos habilita a analisar esses elementos do comportamento e atuação dos mediadores.

Outra limitação do trabalho é o seu sentido de exercício. Vale aqui muito mais a conformação e o amadurecimento de uma nova proposta metodológica e as pistas apontadas pelo percurso analítico do que respostas e conclusões que possam ser elencadas. Os resultados desta análise apontam para o funcionamento do conceito de modos de endereçamento para a análise da qualidade televisiva (no que se refere à utilização dos recursos do meio), e para a necessidade de análise de outros telejornais para a determinação de resultados precisos.

\section{REFERÊNCIAS}

BALANÇO GERAL, [20--?]. Disponível em: <http://www. itapoanonline.com/main/balancogeral/ default.aspx $>$. Acesso em: 15 maio 2009.

CUNHA, Piedra Magnani da. A questão do popular na TV: interlocuções entre programas populares e telespectadores. 2005. Dissertação (Mestrado em Comunicação) - Faculdade Filosofia e Ciências Humanas, Universidade Federal de Minas Gerais, Belo Horizonte.

FREIRE FILHO, João. Notas históricas sobre o conceito de qualidade na crítica televisual brasileira. Galáxia, São Paulo, v. n. 7, p. 85-110, abr. 2004.

GOMES, Itania; GUTMANN, Juliana F.; SANTOS, Thiago E. F. Eles estão à solta, mas nós estamos correndo atrás - jornalismo e entretenimento no custe o que custar. E-compós, Brasília, v. 11, n. 2, maio/ago. 2008. 
et al. Quem o jornal do SBT pensa que somos? Modos de endereçamento no telejornalismo show. Revista da FAMECOS, Porto Alegre, v. 26, p. 85-98, 2004.

Modo de endereçamento no telejornalismo do horário nobre brasileiro: o Jornal Nacional, da Rede Globo de Televisão. In: CONGRESSO INTERCOM, 5., 2005, Rio de Janeiro. Anais... Rio de Janeiro: UERJ, 2005. v. 1, p. 54-72.

MACHADO, Arlindo. A televisão levada a sério. São Paulo: Ed. Senac, 2000.

MELO, José Marques de. Populismo e comunicação. São Paulo: Cortez, 1981.

VERÓN, Eliseo. Esta ahí, lo veo, me habla. Tradução Maria Rosa Del Coto. Enunciacion et cinema: Revista Comunicativa, Paris, n. 38, 1983.

WILLIAMS, Raymond. Television: technology and cultural form. 2. ed. London: Routledge, 1997. 


\title{
Jornal da Massa: \\ jornalismo ou programa de humor?
}

\author{
Mirella Santos Freitas
}

\begin{abstract}
Boa noite, Brasil, estamos começando neste sábado mais um Jornal da Massa pra todo o Brasil. O que é que o Jornal da Massa é? Mostramos um montão de coisas e fazemos um resumo do que foi importante na semana. É assim que funciona o Jornal da Massa. A gente põe o nome de jornal, mas não é jornal. É uma mistura de nada com coisa nenhuma, entendeu?
\end{abstract}

É isso aí...

Carlos Massa, Jornal da Massa, 11 de agosto de 2007.

\section{INTRODUÇÃO}

O Jornal da Massa foi inicialmente exibido de segunda a sexta-feira, às 21h45min, com meia hora de duração. Em maio de 2007, passou a ser apresentado apenas aos sábados com $1 \mathrm{~h}$ de duração, porém mantendo a mesma proposta inicial, de ser um telejornal irreverente, com características variadas, que trata de temas diversos, como saúde, educação, cotidiano, trânsito etc. e está sempre a serviço do telespectador, conforme anuncia o site oficial do programa ${ }^{1}$.

O programa é apresentado por Carlos Massa, conhecido popularmente como Ratinho. O apresentador foi contratado pelo SBT no final dos anos 90, para dirigir, inicialmente, o Programa do Ratinho ${ }^{2}$, representando para a emissora um considerável aumento de audiência no horário. Este pro-

1 SBT. Jornal da Massa. Site oficial do programa. Disponível em: <http://www.sbt.com.br/ jornalismo/jornaldamassa>. Acesso em: 28 dez. 2008.

2 O Programa Ratinho Livre estreou na TV Record em 1977, chegando a alcançar picos de audiência de 50 pontos no IBOPE. Os principais assuntos abortados no programa envolviam brigas familiares, testes de paternidade (DNA), casos de adultério, entre outros. Em 1998, o programa passou a ser exibido no SBT, recebeu o nome Programa do Ratinho e conservou a mesma estrutura do anterior, explorando os mesmos temas e competindo com as telenovelas da Rede Globo. (AMARAL, 2006, p. 46) 
grama pautava-se nos dramas do homem comum, explorando a estética do grotesco, a partir da criação de uma tensão entre os participantes com um apelo de tornar o trágico algo risível. (SODRÉ; PAIVA, 2002, p. 28)

Apesar da alta audiência do programa, as críticas de grupos e entidades que se preocupam com a ética na comunicação ${ }^{3}$ contribuíram para que o programa saísse do ar em agosto de 2006. Cinco meses depois, em janeiro de 2007, estreia o Jornal da Massa, um programa dividido em dois blocos e construído em torno de pautas que se limitam, basicamente, aos acontecimentos do Estado de São Paulo e versam sobre política, fatos do cotidiano e curiosidades, sendo a abordagem humorística um traço marcante em todas as suas editorias.

Os quadros que compõem o programa são: Vamos Girar, No Mundo das Celebridades, Tá Maluco?, Presidente, Notícias da Semana e Território Selvagem. Este último é produzido pela veterinária e jornalista Emanuela Hochmann que, a cada reportagem, traz curiosidades sobre um animal diferente, relatando acerca de seu habitat e características.

Além destes quadros, existem algumas entrevistas no estúdio, com cantores e artistas, principalmente. Neste ponto, o programa traz um formato interessante, o ator convidado está sempre representando seu(s) personagem(s) enquanto é entrevistado por Carlos Massa. Alguns chegam a fazer parte da programação semanal, como a atriz Daniela Calabresa, a "Pedrina", que vestida de servente aparece no programa limpando a mesa do apresentador e se anuncia como "caixinha de banheiro" do SBT.

Pedrina - “Tudo bom seu Ratinho, aquele menino alí ó (aponta para alguém) mandou eu entrar pra passar um paninho, eu não sabia que as máquinas fotográfica tavam funcionando não”.

Ratinho - "Não é máquina fotográfica, é câmera [...]"

Pedrina - "Num tira foto minha não que eu num gosto [...]"

Ratinho - "Não é foto não. Você faz o quê?"

3 A campanha "Quem financia a Baixaria é contra a Cidadania", lançada em 2003, teve apoio de mais de 50 entidades da sociedade civil, o que acabou inviabilizando comercialmente o Programa do Ratinho devido à falta de anunciantes e à queda brutal de audiência. 
Pedrina - Eu sou caixinha de banheiro aqui do SBT. Eu sou, num sou artrística não gente. É que a pessoa faltou, aí eles mandaram eu entrar e sentar. É tudo improvisado, eu nem ganhei lanche, mas eles mandaram eu entrar... Darfine e Mariane você grave minha filha. Chame Maitê Melissa e mande apertar o REC pra vocês me ver na VHS depois ${ }^{4}$.

Dentro da brincadeira, que faz parte da construção do programa, o apresentador, após tecer um diálogo bem humorado com a atriz, anuncia a peça que está em cartaz em São Paulo.

Ratinho - "Eu tô aqui conversando com uma atriz maravilhosa que é a Daniela $[. .$.$] e essa personagem que você está fazendo agora comigo você$ faz no teatro não é?"

Alguns personagens são criados pela produção do programa para deixá-lo ainda mais descontraído e engraçado. Na edição do dia 14 de julho, antes que Carlos Massa desse o "Boa Noite" de abertura do programa, aparece uma voz dos bastidores chamando o apresentador para entregar-lhe uma encomenda. É o “seu Zé”, um ator contratado para fazer pequenas interrupções no programa, e provocar risos. Ele assume o papel de um funcionário do SBT, uma espécie de office-boy desajeitado que entra no meio da cena para entregar uma cesta de presente que enviaram para Carlos Massa. Após entregar a encomenda, seu Zé pega o cartão para ler e, como ele, aparentemente, ainda está sendo alfabetizado, sua leitura é soletrada trazendo um tom cômico à cena.

Seu Zé - “Tem um negócio aqui para lhe dar, é lá de Piráçu-pirá... é, é, c-o-co-co-p-1-e-comple-xo".

A forte presença do humor no programa aliado a alguns depoimentos divulgados na imprensa, bem como ao posicionamento do próprio apresentador Carlos Massa levantaram o questionamento central deste artigo: a definição do gênero.

$\mathrm{Na}$ edição do dia 09 de junho de 2007, o apresentador Carlos Massa encerra o jornal com a seguinte frase:

4 Jornal da Massa, programa exibido em 26 de maio de 2007. 
Ratinho - E o Jornal da Massa vai ficando por aqui, eu queria agradecer a audiência de vocês e espero que vocês continuem porque vem aí um jornal sensacional, vem aí um jornal de verdade mesmo, vem aí o SBT Brasil, jornal de verdade 5 .

Ao enfatizar que o programa a seguir é um jornal de verdade, Carlos Massa estaria questionando o seu próprio programa. Em edição posterior, do dia 11 de agosto do mesmo ano, o mediador deixa claro a ideia que tem do programa que apresenta.

Ratinho - O que é que o Jornal da Massa é? Mostramos um montão de coisa e fazemos um resumo do que foi importante na semana. É assim que funciona o Jornal da Massa. Agente põe o nome de jornal, mas não é jornal. É uma mistura de nada com coisa nenhuma, entendeu? É isso aí6.

De acordo com o diretor de jornalismo do SBT, Paulo Nicolau, em entrevista à Folha Online, em 10 de maio de 2007, o "Jornal da Massa é mais para a gente se divertir fazendo, entendeu? É muito divertido, a gente dá muita risada". (MUNIZ, 2007) Com essa afirmativa, o diretor destaca apenas o apelo humorístico do programa, o que aguça ainda mais a necessidade de uma análise que permita classificar o seu gênero.

Uma matéria publicada na Folha de São Paulo, em 03 de janeiro de 2007, pela jornalista Laura Mattos, faz uma crítica ao programa Jornal da Massa, classificando-o como "um programa trash" e considerando o que ele faz como um "pseudojornalismo" - para usar as palavras da jornalista. Esta mesma matéria traz um depoimento de Luiz Gonzaga Mineiro, diretor de jornalismo contratado em 2005 para reimplantar o jornalismo no SBT. Segundo a Folha, Luiz Gonzaga Mineiro admitiu que o Jornal da Massa não é um telejornal, embora carregue esse nome. (MATOS, 2007)

Partindo destes posicionamentos, este artigo propõe uma discussão sobre o gênero do programa, a partir da análise dos modos de endereçamento, observando a maneira como o Jornal da Massa dialoga com al-

5 Jornal da Massa, programa exibido em 9 de junho de 2007.

6 Jornal da Massa, programa exibido em 11 de agosto de 2007. 
gumas premissas básicas do jornalismo e o modo como estabelece uma relação com sua audiência. O artigo toma como corpus de análise nove edições do programa veiculadas durante cinco meses (março, abril, maio, junho e julho de 2007).

Gênero é aqui entendido como uma estratégia de comunicabilidade que funciona como um mediador do sistema produtivo e seus usos e, a partir dele, é possível indicar modos culturalmente estabelecidos e reconhecidos tanto pelo emissor como pelo receptor. Através dos códigos culturais contidos no gênero e conhecidos pela recepção, a audiência consegue, mesmo que de forma inconsciente, decodificar e incorporar o sentido daquilo que assiste. De acordo com Itania Gomes (2004, p. 238),

[...] os gêneros são formas reconhecidas socialmente a partir das quais se classifica um produto dos media [...] colocar a atenção nos gêneros implica reconhecer que o receptor orienta sua interação com o programa e com o meio de comunicação de acordo com as expectativas geradas pelo próprio reconhecimento do gênero.

Para compreender o gêenero, Martín Barbero (1997) propõe que se analise não aquilo que acontece no texto, mas o que se constrói pelo texto. Citando Itania Gomes (2004), “[...] os gêneros permitiriam entender o processo comunicativo não a partir das mensag'ens, mas a partir da 'interação"'. Dentro deste processo comunicativo é importante também considerar, para a análise do gênero, que a negociação entre emissores e receptores a partir das mediações está articulada a dimensões históricas de seu espaço de produção e apropriação de sentido. Assim, “[...] não podemos entender o sentido dos gêneros senão em termos de sua relação com as transformações culturais na história [...]." (BARBERO apud GOMES, 2004, p. 208)

Portanto, para iniciar uma análise do Jornal da Massa e desenvolver uma discussão sobre gênero, é interessante compreender a presença desse programa dentro da grade de programação da emissora, a partir de sua contextualização histórica. 


\section{CONTEXTUALIZAÇÃO HISTÓRICA DO SBT}

O Sistema Brasileiro de Televisão foi ao ar, pela primeira vez, em 19 de agosto de 1981, inaugurando sua programação com a transmissão da assinatura de contrato entre o empresário e radialista Senhor Abravanel, popularmente conhecido como Silvio Santos, o Governo Federal, representado pelo então presidente Ernesto Geisel, e o Ministro das Comunicações, Euclides Quandt de Oliveira. A programação incluía filmes, desenhos, um pouco de jornalismo, além de programas como Silvio Santos, Povo na TV, Moacyr Franco Show, dentre outros, que fizeram a emissora alcançar $24 \%$ de audiência no primeiro ano de operação. (HISTÓRIA..., 2009)

Desde o seu início percebe-se um forte direcionamento para o popular. Mas foi entre 1983 e 1987 que o SBT se consagrou como uma emissora genuinamente popular, ao exibir os programas de Flávio Cavalcanti, Lolita e Airton Rodrigues, e Hebe Camargo, bem como a série Joana, com Regina Duarte, e a minissérie Pássaros Feridos. Logo após este período, passaram a ser apresentados os programas Aqui Agora ${ }^{7}$ (1990), Programa Livre e A Praça é Nossa. Em 1993, estreia mais um programa popular Domingo Legal apresentado por Gugu Liberato. Em 1994, firma-se o núcleo de dramaturgia da emissora, com a novela Éramos Seis.

A contratação de profissionais como Boris Casoy, que comandava o TJ Brasil e que marcou sua passagem no jornalismo com o bordão "Isso é uma vergonha"; o humorista e escritor Jô Soares, Carlos Alberto de Nóbrega, Alberto Tamer e Hermano Henning, atual apresentador do Jornal do SBT - Edição Manhã, entre 1988 e 1990, sinalizou a preocupação da emissora em fortalecer o jornalismo. Ao longo da década de 80, quatro telejornais foram ao ar: Cidade 4, 24 horas, Noticentro e Últimas Notícias. Em 1991, o TJ Brasil ganha a sua $2^{a}$ edição, transmitida às 21h20min, pela jornalista Lílian Witte Fibe.

7 Este programa foi trazido do rádio e se tornou um marco no telejornalismo popular. O programa Aqui Agora, apresentado pelo radialista Gil Gomes, foi um dos programas populares de maior audiência na TV brasileira, chegando a ter duas edições em 1992 e permanecendo no ar até 1997. O sucesso desse programa inspirou outras emissoras a investirem em telejornais populares. 
A partir da década de 90, alguns telejornais populares estrearam nas outras emissoras de TV, promovendo um boom de programas do gênero na TV, como Repórter Cidadão (Rede TV), Cidade Alerta (Rede Record), Brasil Urgente (Rede Bandeirantes) e Linha Direta (Rede Globo). É nesse contexto que se justifica a contratação do apresentador Carlos Massa pelo SBT no final dos anos 90 para dirigir, inicialmente, o Programa do Ratinho (exibido até agosto de 2006). O retorno de Carlos Massa à TV, em janeiro de 2007 (cinco meses depois), para liderar o Jornal da Massa garantiu ao SBT recuperar a vice-liderança de audiência que há dois meses pertencia à Record. Logo no primeiro mês de estreia, o Jornal da Massa obteve média de 6,5 pontos contra 5,4 da Record, que exibia no horário o desenho animado Pica-pau. (MATOS, 2007) Ainda no primeiro mês de estreia, o Jornal da Massa chegou a marcar 9 pontos, com picos de 10 e 15\% de participação, ficando em terceiro lugar de audiência (Globo: 29 pontos; Record: 14 pontos; Rede TV: 4 pontos) ${ }^{8}$. Entretanto, esta posição não se manteve nos meses seguintes forçando a emissora - em maio do mesmo ano, três meses após sua estreia - a limitar a exibição do programa apenas aos sábados e, em menos de 1 ano de exibição, tirá-lo do ar.

A saída do Jornal da Massa da grade de programação do SBT, em menos de um ano de exibição, devido, principalmente, à baixa audiência que o programa vinha tendo, pode ser também pensada a partir da problemática gerada em torno do gênero e citada no início do texto. O desencontro de opiniões e posicionamentos por parte dos seus produtores acerca do gênero do programa pode ter comprometido a construção de uma relação de credibilidade entre o programa, enquanto telejornal, e a sua audiência.

A análise do modo de endereçamento do programa ajudará a compreender a relação estabelecida entre o Jornal da Massa e o telespectador, bem como fornecerá elementos importantes para entender a construção do gênero do programa.

8 Dados consultados no site <http://audiencia.uniblog.com.br/164789/jornal-da-massa-bem-no-ibope.html>. Acesso em: 28 dez. 2008. 


\section{O PAPEL DO MEDIADOR NO JORNAL DA MASSA}

O lugar do mediador é fundamental para a análise deste programa, visto que o apresentador Carlos Massa desempenha um papel determinante no endereçamento do programa. Popularmente conhecido como Ratinho, Carlos Roberto Massa ${ }^{9}$ assume uma postura contestadora e polêmica dentro do programa. Características já conhecidas pelo público a partir da história do apresentador dentro do campo midiático. É ele quem media a relação entre o programa, os telespectadores, os convidados, os repórteres e os demais profissionais envolvidos. Desse modo, o programa constrói-se na condição de posicionar o radialista e apresentador Carlos Massa como uma figura central dentro do Jornal da Massa; ele é aquele que conduz as entrevistas, as matérias, as intervenções humorísticas e quem primeiro estabelece um pacto ${ }^{10} \mathrm{com}$ a audiência. "Tem que falar, porque o povo tem que entender, tem que parar de falar conversa fiada... peraí eu tenho que falar pô, o homem fica aí falando bobagem!" Carlos Massa grita com gestos agressivos para a câmera e tenta transmitir para o telespectador que ele tem um compromisso com a verdade ${ }^{11}$. "Eu quero dizer ao Brasil que agora vamos resolver muito mais, que agora estou com autorização pra resolver muito mais pelo povo brasileiro" - posicionando-se como alguém que está do lado do povo para ajudar a resolver os problemas da população, seja delatando abusos e cobrando providências dos poderes púbicos, seja proporcionando ao povo esperança, ao tentar ajudar alguma família em situação difícil"12. "Vem cá dona de casa, aqui

9 Radialista e apresentador de televisão, Carlos Roberto Massa também foi deputado federal pelo PRN na década de 90. No SBT, foi apresentador do Programa do Ratinho, Show do Ratinho, Você é o Jurado e participou do especial humorístico SBT Palace Hotel. Na Rede Record, apresentou o Ratinho Livre e Ratinho Show. E na CNT conduziu o programa 190 Urgente. Disponível em: <http://pt.wikipedia.org/wiki/Carlos_Roberto_Massa〉. Acesso em: 04 jun. 2009

10 O pacto é estabelecido entre o programa e sua audiência, por meio de uma série de acordos tácitos que irão orientar o telespectador sobre o que ele pode esperar do programa. (GOMES, 2004) Esses acordos são construídos a partir de uma relação entre o gênero do programa jornalístico e com as especificidades de cada subgênero. No Jornal da Massa, são analisadas as relações que o programa estabelece com algumas premissas básicas do jornalismo (verdade, objetividade, relevância, serviço público, responsabilidade social etc.).

11 Jornal da Massa, programa transmitido em 12 de março de 2007.

12 Jornal da Massa, programa transmitido em 16 de junho de 2007. 
comigo, aqui comigo, dona de casa", interpela o apresentador enquanto a câmera se aproxima até focar o seu rosto. "Sabe quanto é que o Brasil vai gastar esse ano com as medalhas? Aquelas medalhas de honra ao mérito pra botar no cangote do povo aí? Gastou 30 milhões de reais, só com medalha e com a festa da medalha $[\ldots] " 13$.

O texto verbal do apresentador Carlos Massa interpela determinado perfil de público e indica quem o programa pensa ser sua audiência. Analisando o texto verbal do mediador é possível perceber que existe pouco cuidado com o uso do português correto, o emprego de gírias e a incorporação de termos e expressões como "cangote"14, "Hoje eu tô soltando fogo pela venta"15 "vai ser burro assim no inferno"; "o de lá ficou com o fiofó encostado"16, compõem um repertório direcionado para um público que está familiarizado com esse tipo de linguagem, considerada aqui como "popular". Além disso, sua fala possui mudanças bruscas de entonação, muitas vezes o apresentador grita, mostra irritação na voz e faz uso de gestos exagerados, levantando e abrindo os braços, balançando as mãos enquanto fala e apontando o dedo para a câmera, quando o assunto permite um tom mais incisivo. Esta postura de apresentação tem sido comum em programas que seguem a linha mais popular e que ganharam destaque na mídia brasileira, a partir da segunda metade da década de 90. Por programas populares considera-se,

um conjunto de programas distintos com características peculiares [...] todos esses programas se assemelham ainda por uma preocupação com índices de audiência a todo custo, o que significa alterar o que for necessário, interromper subitamente determinado quadro, trocar personagens, temas, formatos ou horários, etc. [...] voltados de forma primordial para a busca de popularidade. (ARAÚJO, 2006, p. 47, 49)

13 Jornal da Massa, programa transmitido em 26 de maio de 2007.

14 Jornal da Massa, programa transmitido em 26 de maio de 2007.

15 Jornal da Massa, programa transmitido em 12 de março de 2007.

16 Jornal da Massa, programa transmitido em 12 de março de 2007 - comentando um vídeo enviado pela internet. 
Ainda segundo o autor, a exploração da vida privada, como a intimidade de pessoas famosas (celebridades) ou de pessoas comuns, é também muito presente nos programas de característica popular ${ }^{17}$. E a presença deste último grupo (pessoas comuns) nos programas populares de TV é percebida a partir de cinco situações-modelo ${ }^{18}$ (ARAÚJO, 2006, p. 53, $55)$ :

O circo: a pessoa passa por uma situação engraçada ou constrangedora no ar, ou vai para exibir características físicas bizarras (doenças, anormalidades) [...]. Tribunal/divã: a pessoa leva seus problemas pessoais e os expõe no programa [...]. Máquina dos sonhos: a pessoa vai ao programa para ver se algum desejo é atendido[...]. Games: pessoas comuns participam de gincanas, torneios, disputas das mais variadas naturezas, com o objetivo de conseguir o prêmio oferecido ao vencedor [...] Vítimas: pessoas expressam seu sofrimento ou revolta em relação a casos de assassinato, estupro, seqüestro e outros atos praticados por criminosos, em depoimentos, muitas vezes, emocionados.

Na edição do dia 14 de março de 2007, o programa exibe o vídeo de uma mulher com problemas de obesidade andando numa esteira e vestida apenas de calcinha e sutiã. Na tela aparece a seguinte frase escrita: “será que tem jeito?”. Durante a exibição do vídeo, o apresentador, que está ao lado do cantor Genival Lacerta (entrevistado do programa), faz comentários pejorativos. Uma situação claramente identificada dentro da categoria de "circo", citada por Araújo.

Embora o mediador esteja na maior parte do tempo sentado atrás da bancada ${ }^{19}$ de onde apresenta o Jornal da Massa, ele se desloca, anda pelo

17 Araújo apropria-se das definições de Goffman para falar sobre fundo e fachada. Sendo fundo tudo aquilo que é sigiloso e fachada o que é exposto. No caso dos programas populares, o autor indica a preferência por expor o fundo ao invés da fachada.

18 Esta classificação feita por Araújo partiu da análise de 18 programas com características populares das quatro principais emissoras do País (Globo, SBT, Band e Record).

19 O cenário do Jornal da Massa é constituído por uma bancada e uma TV de plasma ao fundo, onde são exibidas as matérias. Esta estrutura de cenário corresponde à estética comumente usada em telejornais. 
estúdio e se aproxima da câmera, quando quer atribuir mais ênfase a algum assunto. Em alguns momentos, chega a apontar o dedo para a câmera e gritar no estúdio, mostrando para o telespectador sua indignação com determinadas situações. Envolve-se com os fatos noticiados e transmite para o telespectador seus sentimentos de raiva, tristeza e revolta, sofrendo com as mesmas angústias que atormentam o telespectador. Com esse posicionamento, o apresentador tenta mostrar que está do lado do povo e em busca de medidas que solucionem os problemas que afligem a sociedade. "Esse tipo de coisa me corta o coração [...] pra você que muitas vezes reclama de pouca coisa olha o sofrimento dessa mulher", apresenta a história de duas garotas gêmeas que se alimentam através de sondas. Após exibição da matéria, o apresentador com os olhos vermelhos e lacrimejados faz um apelo: "Prefeito, eu gostaria muito de chegar aqui segunda-feira e dizer aqui pro meu público que [...] o senhor arrumou uma ambulância pra levar”. (referindo-se à locomoção diária dessas duas garotas de casa para o hospital) ${ }^{20}$.

Na edição do dia 23 de março, é mostrada a discussão no congresso sobre o "apagão" aéreo. Após a exibição da matéria, o apresentador, em um tom de voz exaltado, tece comentários sobre a situação aeroportuária. Nesse momento, a câmera está focada no rosto de Carlos Massa, registrando sua expressão de indignação e revolta e convocando a atenção do público para o que está sendo dito.

Ratinho - Tá uma palhaçada esse negócio do apagão aéreo, tá uma palhaçada, viu?! Faz 300 anos que nós temos aviação aérea e agora que ficou ruim?! De um mês pra cá, dois meses pra cá que tão inventando essa história de apagão?! Tem que saber o que está acontecendo, o que está acontecendo! Como é que de repente, quando nunca teve problema, que o problema começou a ficar depois que caiu aquele avião com 150 pessoas... tem que ver o que está acontecendo. Tão com medo de quê?! Tão com medo da polícia descobrir pra onde vai o dinheiro da Infraero?! É isso que vocês tão com medo?! VAMO ABRIR A CAIXA PRETA! ${ }^{21}$

20 Programa transmitido em 14 de março de 2007.

21 Jornal da Massa, programa exibido em 23 de março de 2007. 
No dia 06 de março, o programa exibe uma matéria sobre a atuação da Força Nacional no combate aos traficantes que invadiram o Complexo do Alemão. A matéria chama a atenção para os armamentos usados pelos traficantes e para a situação dos moradores diante da troca de tiros com a polícia. Após a exibição da matéria, o apresentador comenta.

Ratinho - Até os traficantes tão tirando um sarrinho dessa Força Nacional que, aliás, tá virando uma piada. Essa 'forseca', essa 'forseca' realmente não resolveu. E eu falei desde o primeiro dia que isso era pra inglês ver, era pra jornal bater foto, é pra Globo colocar no Jornal Nacional, é pro SBT colocar no SBT Brasil, e eu não coloquei aqui porque eu não vou fazer esse papel, eu num vou fazer! Eu sabia que não ia dar certo, eu sabia. Querem 40 dias para treiná, pra entrar na favela, oi lá?! E o traficante ainda abusa: - vem 'forseca', vêm cá! Olha a arma dos traficantes! mostra aí. É pra derrubar helicóptero, ainda bem que a Força Nacional não tem helicóptero... e o Lulu? O nosso querido presidente finge que não é com ele. - Não é comigo. Esse negócio de segurança, não é comigo ${ }^{22}$.

O apelo retórico e argumentativo presente nos comentários do apresentador, associado à sua habilidade enquanto orador e ao uso de uma linguagem comum, popular e incisiva, aparece como uma estratégia de estabelecer uma relação de credibilidade com o telespectador. Além disso, Carlos Massa, em sua fala, posiciona-se ao lado do povo, preocupado em ajudar a resolver os problemas da maioria da população que não se vê assistida, nem ouvida. O mediador estaria se posicionando como um porta-voz do povo, disposto a intervir em nome da população. Esse posicionamento em prol do povo ajuda na construção de uma relação de empatia e confiança entre o mediador e o telespectador.

Quem tá perdendo com essa história toda é o povo [...] Quando é pobre e negro realmente o povo esquece muito mais rápido do que quando é branco e rico [...] nós temos que crescer o número de manifestação que é pra dizer: olha senhor presidente, nós estamos insatisfeitos!23

22 Jornal da Massa, programa exibido em 6 de março de 2007.

23 Jornal da Massa, programa transmitido em 12 de março de 2007. 
Carlos Massa grita para as câmeras, mostrando irritação e indignação à falta de segurança que levou à morte uma garota vítima de uma bala perdida num confronto entre a polícia e os bandidos no subúrbio de São Paulo.

O mediador assume o papel, não só de enunciar os VTs e matérias, mas também o de comentar todos os assuntos apresentados no programa. Esse discurso opinativo é acompanhado por uma linguagem sensacionalista e popular:

Ratinho - Vocês viram aí esse menino de 7 anos comprando cocaína e munição. Quer dizer, eu sempre tenho falado, quando você, quando o pai não cuida do filho e o Estado não tem tempo pra cuidar ou não liga pra cuidar, quem é que cuida? O traficante adota. Esse menino já foi adotado por algum bandido porque a mãe não cuida, o pai não cuida, a escola não cuida, o Estado não cuida... a obrigação primeira é da família cuidar ${ }^{24}$.

O mediador convoca a audiência através do uso da primeira pessoa do singular (eu) em seu texto verbal e, assim, fala diretamente com o público, estabelecendo uma maior aproximação com o telespectador. "Eu sempre tenho falado" 25; "faço aqui essa convocação mesmo, vamo ter que acabar com essa violência no Brasil, eu tô aqui fazendo essa guerra" 26 . "Vem cá dona de casa, aqui comigo, aqui comigo, dona de casa" 27 . "Vamo lá, vamo aqui... essa quem mandou foi o Felipe Camargo de Pernambuco, vamo encher a telona vai" - valorizando a participação da audiência no programa $^{28}$.

O apresentador também interage com os bastidores do programa e faz piadas com os câmeras e os auxiliares de estúdio, demonstrando grande intimidade com a equipe de produção: "você gosta de biscoito

24 Jornal da Massa, programa transmitido em 26 de maio de 2007

25 Jornal da Massa, programa transmitido em 12 de junho de 2007.

26 Jornal da Massa, programa transmitido em 14 de março de 2007.

27 Jornal da Massa, programa transmitido em 26 de maio de 2007.

28 Jornal da Massa, programa transmitido em 26 de maio de 2007. 
de polvilho?" 29 (para introduzir uma matéria que mostra como é feito o biscoito de polvilho); "como é que chama aquele treco que põe na canela Humberto? (falando com o operador de câmera no estúdio); "Como é que é o nome do galã aí do lado? Ô Valdeco é platina num é Valdeco?... Valdeco é o Valdecão nas horas vagas"30 (brinca com algum câmera ou auxiliar que está no estúdio, mas que não aparece na cena). Em alguns momentos, o apresentador solicita a presença de Pedrina, a atriz que faz o papel de caixinha de banheiro do SBT, chamando-a no estúdio para conversar sobre as matérias que serão veiculadas. O apresentador atribui um caráter informal e de improviso ao programa, transmitindo para o telespectador a ideia de que o programa é "ao vivo". "Pára, pára, pára, pára, tira esse negócio de ioiô. Quem quer saber de ioiô? Eu não quero saber de ioiô!" (interrompe o vídeo que acaba de exibir sobre o "rei do ioiô', um homem que faz truques com o brinquedo ${ }^{31}$.

\section{OUTROS ELEMENTOS PRESENTES NA CONSTRUÇÃO DO PROGRAMA}

O quadro Presidenciáveis apresenta elementos interessantes para a análise do programa. Neste quadro, a figura do presidente Lula é usada para satirizar a política e a atuação do governo, através de críticas ao atual sistema de educação ${ }^{32}$, à impunidade de Vavá, irmão do presidente, ${ }^{33}$ à declaração da ministra Marta Suplicy "Relaxe e goze, pois depois você esquece todos os transtornos" ${ }^{34}$, às acusações contra Renan Calheiros ${ }^{35}$, dentre outras. Um ator caracterizado como o presidente Lula e imitando a sua voz e o seu jeito de falar, comenta sobre algum tema.

Lula (ator) - Olha companheiros e companheiras, companheiro Ratinho, é preciso que se diga que nunca em nenhum governo fez

29 Jornal da Massa, programa transmitido em 23 de junho de 2007. 30 Jornal da Massa, programa transmitido em 12 de março de 2007. 31 Jornal da Massa, programa transmitido em 12 de março de 2007. 32 Jornal da Massa, programa transmitido em 14 de julho de 2007. 33 Jornal da Massa, programa transmitido em 16 de junho de 2007. 34 Jornal da Massa, programa transmitido em 16 de junho de 2007. 35 Jornal da Massa, programa transmitido em 23 de junho de 2007. 
tanto para esclarecer a venda de gado, a venda da carne de vaca, como o meu governo tá fazendo. E eu queria dizer que no meu governo, vou dar nome aos bois, vou dar apelido às vacas, vou dar sobrenome pros bezerros. Isso é um governo. E hoje vamos falar desse caso, se Renan perdeu as vacas, se vendeu o boi, se a vaca foi pro brejo, isso não importa. E olha só que bucho nós arrumamos na política, inclusive quero dizer que meu amigo senador complicado, ele está fazendo das tripas coração pra sair dessa encrenca ${ }^{36}$.

Lula (ator) - Companheiros e companheiras é preciso que se diga que nunca, nunca em nenhum governo se fez tanto pelos irmãos, primos, tios, pai, avós, como o meu governo está fazendo. Isso eu admito... companheiro irmão Vavá, eu tô muito chateado. Nunca nenhum outro governo ficou tão chateado como o meu ficou com o irmão Vavá. Vavá, que papo atravessado é esse Vavá, que você pediu dois mi?! ${ }^{37}$

Vavá (ator) - "Ô mano, eu falei dois mi, três pamonha, dois cuzcuz, um suco de milho verde, foi isso que eu falei. Mano, por mim você pode botar as mão no fogo mano" 38 .

Nota-se no trecho acima o uso de expressões populares, de adjetivações e de um tom irônico ao tratar dos assuntos políticos. A partir deste quadro, intitulado Presidenciáveis, percebe-se a sátira usada pelo programa ao abordar assuntos políticos. Este tipo de tratamento dado, entretanto, demanda um conhecimento prévio do telespectador, que só irá compreender a sátira se souber o que está acontecendo na esfera política.

Embora o Jornal da Massa paute seus assuntos em notícias da semana, não atualizando, necessariamente, com os últimos acontecimentos, o programa não deixa de negociar com a premissa da atualidade, uma vez que as discussões trazidas no Jornal da Massa fazem parte da agenda-setting, ou seja, estão em pauta na agenda dos media.

A vinheta de abertura do Jornal da Massa antecipa algumas promessas do programa. O encadeamento das imagens e o som da vinheta trazem a

36 Jornal da Massa, programa transmitido em 23 de junho de 2007.

37 Jornal da Massa, programa transmitido em 16 de junho de 2007.

38 Jornal da Massa, programa transmitido em 16 de junho de 2007. 
ideia de agilidade e a presença do povo nas ruas sugere que o programa está direcionado para a "massa", como o próprio nome anuncia, permitindo ainda um trocadilho com o sobrenome do mediador.

A utilização de som de hélice de helicóptero e de sirene de ambulância, bem como a velocidade com que a câmera sobrevoa as pessoas na vinheta de abertura do programa refletem um caráter de emergência e atribuem um ritmo acelerado ao programa. Na sequência de imagens, uma porta é aberta, como se estivesse abrindo caminho para o telespectador ansioso por assistir o referido jornal. Uma multidão está nas ruas dirigindo-se para o espaço onde está afixado um grande telão que exibirá o Jornal da Massa.

Este ritmo, sugerido pela vinheta de abertura e seguido pelo moderador, é também percebido nos quadros que preenchem a maior parte do programa, apresentando uma síntese dos principais acontecimentos do Brasil e do mundo. O noticiário é composto por curiosidades como o concurso de ioiô, o casamento do homem mais alto do mundo, a tradição de saltar um colchão com vários bebês recém-nascidos, notícias sobre celebridades, o casamento entre árvores, a comemoração do aniversário de um ano de um elefante etc. Em uma proporção consideravelmente menor, estes quadros incluem também resumos do que está acontecendo na política nacional e estrangeira.

Na edição do dia 30 de junho, é exibida uma matéria sobre um garoto que se acidenta na escola e é submetido a cirurgia. A música escolhida como fundo para a matéria tenta sensibilizar o telespectador. Em um depoimento emocionado, a mãe do garoto fala do presente que o filho pediu de aniversário e que ela não pôde dar. A diretora da escola e o médico também são ouvidos. De um lado, a família do garoto, sensibilizada com o ocorrido, e, do outro, a escola, local onde o acidente aconteceu. O texto da repórter alimentava a acusação da mãe contra a escola e a professora do menino. Na nota pé da matéria, a frase "A família quer saber a verdade" tentava trazer um sentimento de investigação e busca da verdade, ao mesmo tempo em que tratava o caso não como um acidente, mas como uma situação em que deveria haver um culpado. Além disso, no fechamento da matéria, a repórter tenta sensibilizar o médico e o teles- 
pectador ao perguntar se ele sabia que, naquele dia, era o aniversário do garoto, comprovando o apelo emotivo buscado desde o início.

Após exibição da matéria, o apresentador comenta:

Ratinho - Aqui ninguém tá acusando escola nenhuma. Eu não tô fazendo nenhuma acusação [...] mas o médico disse que não é um tombo comum, foi um tombo muito violento, e agora a escola tá falando que ele caiu de um muro alto?! Antes não era muro alto, agora já é muro alto. É engraçado isso, mas enfim, tá acontecendo uma investigação e o nosso programa vai acompanhar essa investigação pra dar o resultado aqui ${ }^{39}$.

Diante disso, seria oportuno questionar a relação que o Jornal da Massa estabelece com a verdade que se manifesta nos programas por meio da apuração da notícia e da exibição de imagens que mostram o que realmente aconteceu. Associa-se à busca da verdade, a clareza com que a notícia é apresentada ao público a partir de uma construção que considere a coerência textual. Na matéria do acidente na escola, o comentário que o apresentador Carlos Massa faz no estúdio (transcrito acima) indica uma preocupação com a apuração da notícia ao afirmar que o programa irá acompanhar a investigação. O texto da matéria, porém, favorece apenas uma interpretação, a de que existe algo que a escola ainda não revelou e que precisa ser investigado: Repórter - "Faz uma semana que dona Jucilene deixou o filho nessa escola municipal, mas o menino foi parar no hospital com traumatismo craniano. O que teria acontecido com o filho dela?" 40

O texto da repórter, as imagens e enquadramentos usados durante a matéria, bem como a trilha musical escolhida para trazer mais emotividade ao fato ocorrido, são posições que se colocam contrárias à postura objetiva ${ }^{41}$ que se espera da construção de uma notícia jornalística. Para ter

39 Jornal da Massa, programa exibido em 30 de junho de 2007.

40 Jornal da Massa, programa exibido em 30 de junho de 2007.

41 De acordo com Schudson (1978) o conceito de objetividade surgiu após a Primeira Guerra Mundial, no final do século XIX, como uma tentativa de resgatar a confiança da população na democracia. O autor explica que, neste período, havia um descrédito muito grande da população com relação à democracia e, especialmente, à política. Os jornalistas tinham perdido 
objetividade, o jornalismo deveria se ater aos fatos e evitar reportagens interpretativas e tendenciosas. Em 1969, o dono do Diário de Wall Street, Sydney Gruson, já declarava "a objetividade pura não poderia existir, mas você tem que se esforçar para isto de qualquer maneira”. (GRUSON apud SCHUDSON, 1978, p. 161)

\section{CONSIDERAÇÕES FINAIS}

Embora o Jornal da Massa não negocie de maneira uniforme com todas as premissas do jornalismo, ele apresenta características que permitem classificá-lo como um programa jornalístico que incorpora elementos próprios do gênero televisivo e possui um forte apelo popular. Esta configuração híbrida permite que o Jornal da Massa utilize estratégias de humor na construção da notícia, na tentativa de produzir um determinado efeito na audiência. A análise permite perceber a importância do papel do mediador, como o condutor principal do telejornal; as estratégias de aproximação com o público, através da interpelação direta ao telespectador; o uso da primeira pessoa do singular; o enquadramento fechado da câmera no apresentador etc., e a relação de credibilidade que se busca estabelecer com a audiência, a partir, principalmente, do texto verbal e do apelo retórico de Carlos Massa, que enfatiza sua preocupação em apurar os fatos (apesar das coberturas jornalísticas serem, em grande maioria, superficiais) e estabelecer um compromisso com a verdade.

Ainda que o programa aborde assuntos sobre política e de interesse público, predomina no Jornal da Massa notícias que servem mais para entreter do que para informar e toda a estrutura do programa é construída a partir de um posicionamento sensacionalista, característica comum entre os programas do gênero popular.

As opiniões da imprensa, bem como o posicionamento do apresentador Carlos Massa e do diretor de jornalismo do SBT, Paulo Nicolau, acerca do gênero do programa podem ter confundido a audiência, mas os códigos/símbolos usados pelo Jornal da Massa como estratégia de comuni-

credibilidade e eram vistos como profissionais não sérios. A objetividade surge nesse contexto, como um ideal a ser alcançado pelo jornalismo e como uma estratégia para recuperar a crença do povo. 
cabilidade são conhecidos pela recepção e reconhecidos como parte de um programa jornalístico que recebe grande interferência do gênero televisivo e que define seu estilo a partir de um forte apelo popular e uma expressiva abordagem de humor.

\section{REFERÊNCIAS}

ALBUQUERQUE, Afonso de. Um outro quarto poder: imprensa e compromisso político no Brasil. Revista Fronteiras - Estudos Midiáticos, v. 1. n. 1, p.07-37, dez. 1999.

AMARAL, Márcia Franz. Jornalismo popular. São Paulo: Comtexto, 2006.

ARAÚJO, Carlos Alberto Ávila. Dramas do cotidiano na programação popular da TV brasileira. In: FRANÇA, Vera (Org.). Narrativas televisivas: programas populares na TV. Belo Horizonte: Autêntica, 2006.

BRAGA, José Luis. "Lugar de fala” como conceito metodológico no estudo de produtos culturais e outras falas. REUNIÃO DA ASSOCIAÇÃO NACIONAL DOS PROGRAMAS DE PÓSGRADUAÇÃO EM COMUNICAÇÃO, 5 1996., São Paulo. Anuais... São Paulo: [s.n.], 1996.

DUARTE, Elizabeth Bastos. Televisão: ensaios metodológicos. São Paulo: Sulina, 2004.

FRANÇA, Vera. Narrativas televisivas: programas populares na TV. Belo Horizonte: Autêntica, 2006.

GOMES, Itania Maria Mota. Efeito e recepção. A interpretação do processo receptivo em duas tradições de investigação sobre os media Rio de Janeiro: E-papers, 2004.

HISTÓRIA da televisão brasileira: Sistema Brasileiro de Televisão - SBT. Disponível em <http://www.microfone.jor.br/hist_sbt. htm $>$. Acesso em: 20 de abril de 2009.

JOST, François. Seis lições sobre televisão. Porto Alegre: Sulina, 2004. 
MARTÍN-BARBERO, Jesús. Dos meios às mediações: comunicação, cultura e hegemonia. Rio de Janeiro: UFRJ, 1997.

MATOS, Laura. Ano começa mal na TV com o "novo" Ratinho. Folha Online, São Paulo, 03 de janeiro de 2007. Disponível em <http://www1.folha.uol.com.br/folha/ ilustrada/ult90u67288. shtml>. Acesso em: 20 abr. 2009.

MUNIZ, Diógenes. "Somos o anti-Jornal Nacional”, diz diretor de jornalismo do SBT. Folha Online, São Paulo, 10 maio 2007. Disponível em: <http://wwwl.folha.uol.com.br/folha/ ilustrada/ult90u70983.shtml $>$. Acesso em: 20 abr. 2009.

SCHUDSON, Michael. Discovering the news: a social history of American newspaper. New York: Basic Books, 1978.

SODRÉ, Muniz e PAIVA, Raquel. O império do grotesco. Rio de Janeiro: Mauad, 2002. 


\title{
É Fantástico! Gênero e modos de endereçamento no telejornalismo show
}

\author{
Luana Gomes
}

\section{INTRODUÇÃO}

Um velho conhecido dos telespectadores brasileiros, o programa Fantástico está no ar, nas noites de domingo, há 33 anos, pela Rede Globo de Televisão. De acordo com o site da emissora, o Fantástico atinge em média 30 pontos de audiência, o que totaliza cerca de 22 milhões de espectadores. O Fantástico é exibido logo após o Domingão do Faustão, em um horário que varia entre as 20h15min e 20h30min até as 22h30min/23h. No período de nossa análise, Sob Nova Direção era o programa humorístico que o sucedia, dentro de uma grade dominical tomada por programas de entretenimento, assim como nas demais emissoras de canal aberto nesse mesmo dia da semana.

Inserido nessa atmosfera de descontração, o Fantástico se utiliza, justamente, do entretenimento, aliado ao jornalismo, para se configurar como revista eletrônica - um gênero telejornalístico, cujas marcas tentaremos, aqui, explorar e definir melhor. Como afirma o site do programa, sua proposta inicial, que perdura até hoje, é "misturar jornalismo e entretenimento de forma dinâmica e acessível" ${ }^{1}$. Mas que jornalismo é esse? De que forma ele é exercido? E mais, como se configura o entretenimento ${ }^{2}$ proposto numa mescla com o jornalismo televisivo? O modo pelo qual se dá essa "mistura" e a configuração que dela resulta, é o que vamos buscar compreender no presente capítulo.

1 Linha do Tempo no site do programa - 1973: estreia com uma receita original. Disponível em: <http://fantastico.globo.com/Jornalismo/FANT/0,15615,00.html>. Acesso em: 13 abr. 2009.

2 Aqui, o entretenimento é visto como elemento indissociável de todas as produções televisivas, compondo uma das três funções clássicas da televisão, ao lado da instrução e da informação, seguindo a perspectiva adotada por Aronchi de Souza (2004). 
O corpus analisado contempla sete exibições do Fantástico, tomadas nas seguintes datas, referentes ao ano de 2006: 19 e 26 de março, 02, 09, 16 e 23 de abril e 07 de maio. Por tratar-se de uma transmissão semanal, acreditou-se que o número de gravações analisadas, aliada ao hábito de audiência da autora deste trabalho, seria o suficiente para dar conta, aqui, das características do programa, que configuram seu estilo particular.

\section{MEDIADORES}

O início de todas as edições analisadas é marcado pela narração do locutor e apresentador Cid Moreira. Sua voz é um dos elementos principais da familiaridade do público com o programa, uma vez que o mesmo está no Fantástico desde sua primeira exibição, em 05 de agosto de 1973. Além disso, o locutor esteve à frente da apresentação do Jornal Nacional o mais antigo telejornal em exibição e o de maior audiência da televisão brasileira (MAIA, 2005) - durante 27 anos, fato que confere a ele toda uma bagagem de credibilidade jornalística levada ao Fantástico. Assim, a voz inconfundível é a responsável, na maioria das edições analisadas, pela abertura do programa que, por sua vez, acontece normalmente sob duas formas.

A primeira delas consiste numa breve apresentação de uma das notícias da edição, que é seguida da vinheta de abertura do programa e da escalada. O programa a adota quando deseja dar destaque especial para alguma matéria. A segunda forma se dá apenas com a escalada, seguida da vinheta. Os dois tipos de abertura utilizados revelam a intenção do programa em enfatizar seu posicionamento jornalístico. Nas duas opções, é dado destaque às notícias que serão apresentadas sob o formato de reportagem (matéria completa com cabeça, off, passagem, sonoras e nota pé), enfatizando a centralidade que o próprio programa confere ao formato jornalístico de apresentação dos seus conteúdos. Ao optar por destacar as reportagens em suas aberturas, o programa revela, ainda, pistas sobre a tentativa de firmar, com sua audiência, um pacto sobre o papel do jornalismo voltado, supostamente, para enfoques completos e informações aprofundadas. 
No programa, a logomarca do Fantástico intercala as notícias na escalada, realizada, em ambos os casos descritos, com a narração de Cid Moreira, sobre imagens sucessivas, ao ritmo sonoro da vinheta da revista - uma bolha luminosa que se projeta do meio de um círculo de nuvens, em um céu azul- escuro, explodindo o nome do Fantástico, em grandes letras douradas, na perspectiva vertical em direção à tela da televisão. Além de estabelecer um pacto específico, que assume dominicalmente com a audiência no início do programa, a vinheta emprega um ritmo dinâmico condizente com a estrutura da revista eletrônica em ofertar conteúdos diversos. Os efeitos visuais e as cores empregadas, sobretudo o dourado, remetem à espetacularização, bem como evidenciam os recursos técnicos a serviço da televisão ali empreendidos, fornecendo pistas sobre o que se esperar do programa: entretenimento. Tais características remetem a um contexto comunicativo baseado nos sentidos de velocidade, rapidez e agilidade na apresentação dos conteúdos, reconhecidos socialmente como marcas do jornalismo. Aliás, a própria escalada é marca dos telejornais brasileiros, utilizada, sem exceção, por todos os jornais nacionais da Rede Globo, por exemplo.

Vale ressaltar que a locução de Cid Moreira traz entonações específicas, para cada tipo de matéria que o mesmo anuncia, numa clara performance vocal. Não há uma narração isenta, imparcial. O tom da voz traz implícito um julgamento sobre aquilo que é narrado, além de uma convocação ao envolvimento com o conteúdo apresentado. Assim, quando diz "crime e castigo! O que aconteceu com Suzane von Richthofen? E por que o jornalista que matou a namorada não quer falar com ninguém?/ O paraíso é aqui! O mar tem sete cores e todo mundo vive mais de cem anos!", há uma perceptível diferença nas entonações utilizadas. Ao tratar do caso de Suzane, a voz é séria, enfática e grave. Quando fala do paraíso, alegre e descontraída. Isso foi verificado em todo o corpus de análise e nos dá pistas da tentativa de condução interpretativa do telespectador, por parte do programa. O tom utilizado sugere à audiência uma predisposição para julgar as notícias, antes mesmo de apresentá-las.

Sete a oito blocos dividem o Fantástico, e ao final de cada um deles acontece a chamada para o bloco seguinte, realizada, quase sempre, pela locução de Cid. Neles, as reportagens trazidas pelo programa também 
aparecem com frequência. O destaque desse tipo de formato de apresentação das notícias é feito, assim, tanto na escalada quanto nas chamadas de bloco, mostrando - tendo em vista a variabilidade de formatos trazidos pelo Fantástico, condizente com o subgênero no qual o programa está inscrito (revista eletrônica) - que o mesmo tem a clara intenção de realçar seu trabalho jornalístico.

A narração de Cid Moreira também acontece em algumas matérias apresentadas ao longo dos programas analisados. Pudemos observar que Cid narra, em geral, notícias relacionadas à política (ex: 19 de março - matéria sobre o depoimento do publicitário Duda Mendonça à CPI dos Correios), ao próprio programa (ex: 16 de abril - lançamento de um novo livro que traz uma das séries apresentadas pelo Fantástico, Instinto Humano) e aquelas de caráter investigativo (ex: 07 de maio - assassinatos que ocorreram no mesmo dia em que o jornalista Pimenta Neves matou a ex-namorada, Sandra Gomide). Desta forma, sua credibilidade jornalística é aproveitada pelo Fantástico, que se fia na trajetória do apresentador dentro da emissora e do telejornalismo, junto aos telespectadores. Assim, toda a confiança que Cid Moreira inspira em função do seu reconhecido trabalho de narração da Bíblia em fascículos, num país marcadamente católico, e sua credibilidade jornalística, aliadas à familiaridade do público com sua voz, acumulada como ex-apresentador do Jornal Nacional, são utilizadas para conferir às matérias um caráter de seriedade e relevância.

Ao realizar a abertura do programa, ser o primeiro a dar "boa-noite" à audiência, dizer a ela quais as principais notícias da edição e dos próximos blocos, Cid Moreira exerce o papel de um coapresentador do Fantástico. "Co" porque não é ele quem está presente no estúdio, olhando para o receptor, apresentado as matérias durante a transmissão e finalizando o programa. Mas, ao mesmo tempo, é ele quem organiza o andamento do mesmo, abrindo as edições, citando as notícias daquele domingo, fechando os blocos e narrando algumas matérias - atividades típicas dos apresentadores.

São os jornalistas Glória Maria (GM) e Zeca Camargo (ZC), por sua vez, os apresentadores principais do Fantástico e a escolha deles para estar à frente das exibições parece refletir a promessa do programa em alinhar 
jornalismo e entretenimento em seu editorial. Glória Maria traz consigo a credibilidade jornalística de uma repórter que trabalhou em diversos telejornais da própria emissora (RJ TV, Jornal Hoje, Jornal Nacional e Globo Repórter), tendo sua história profissional voltada para reportagens especiais e cobertura de guerra. Realiza matérias no Fantástico imbuídas de um caráter de divertimento e descontração, onde mantém, contudo, a postura jornalística de acompanhar de perto as situações que noticia, muitas vezes as vivenciando. Já o editor-chefe, Zeca Camargo, transporta toda uma bagagem proveniente do canal Music Television (MTV), da revista Capricho e do programa Fanzine (TV Cultura), que o credita como um profissional alinhado às tendências culturais da juventude e do futuro e, por isso mesmo, capacitado para a realização de entrevistas com músicos, artistas, matérias sobre viagens pelo mundo, entre outras.

Pedro Bial também integra a equipe de mediadores do programa. É dele o livro sobre Roberto Marinho, além de crônicas realizadas no Jornal Nacional, como pudemos observar durante a Copa do Mundo (24 de junho a 05 de julho de 2006), e de sua presença na Caravana JN, durante a campanha presidencial de 2006. Esse status de seriedade, construído durante sua trajetória profissional, marcada por importantes coberturas, como a da queda do Muro de Berlim, aliado às apresentações do programa Big Brother Brasil, tornam sua carreira alinhada à proposta central da revista eletrônica em oferecer "infotenimento". Temos, ainda, Renata Ceribelli, que trabalhou durante seis anos no Vídeo Show e em 1999 entrou para a revista eletrônica sendo, portanto, já conhecida pelo público através de um programa diário de entretenimento.

Não podemos deixar de fora do grupo Eva Byte, a primeira apresentadora virtual da televisão brasileira, segundo o site do programa, o que justifica mesmo seu próprio nome. Ela foi criada em 2004 pelo Departamento de Arte e Jornalismo da Rede Globo e reflete a utilização dos recursos técnicos a serviço da televisão por parte do programa, sustentando certo pioneirismo tecnológico do Fantástico, o que busca evidenciar a habilidade técnica da equipe em lidar com os avanços da tecnologia e incorporá-los à revista. A seu cargo, ficam as matérias de linha científica, as quais Byte, por ser ela mesma uma criação tecnológica, parece ter 
autoridade sobre aquilo que fala. A apresentadora virtual traz, também, notícias descontraídas, cujas temáticas são leves e variadas - soft news -, onde funciona como um reforço do caráter de descontração dos temas e do contexto comunicativo do Fantástico. Sua semelhança com Fátima Bernardes, um das âncoras do Jornal Nacional, parece uma tentativa do programa em substituir sua falta de background jornalístico.

Glória Maria e Zeca Camargo encontram-se sempre bem vestidos e alinhados, de maneira diferenciada, no entanto, do tradicional modo de se vestir dos apresentadores de telejornais. Glória Maria normalmente usa roupas com brilho, sandálias altas, decotes e jóias. Zeca Camargo, sapatos alinhados, blazers abertos, camisas coloridas, enfim, ambos se enquadram em um visual moderno. A aposta da revista em vestimentas nesse estilo, fora dos moldes telejornalísticos, reflete uma das marcas do gênero no qual o programa está inscrito, revelando que, apesar de se aproximar do telejornal, o mesmo borra suas fronteiras, buscando caracterizar os apresentadores da mesma forma que busca caracterizar o jornalismo oferecido: "showrnalismo". (ARBEX JR, 2002)

Na condução do Fantástico, os apresentadores dão pequenos passos, posicionam-se em diferentes pontos do cenário durante o programa e fazem uso de um sistema gestual fino, restrito às expressões faciais e a pequenos movimentos com as mãos. Essa gestualidade, aliada às entonações de voz específicas que imprimem aos fatos narrados, fazem com que os apresentadores assumam a postura de "mediadores-intérpretes"3 das notícias. Os apresentadores também estabelecem com o telespectador uma dimensão de contato baseada no olhar, que colabora para a desficcionalizar o discurso. Com estes artifícios citados, a dupla também conduz a interpretação dos telespectadores com

3 Essa classificação dos mediadores é situada entre dois modelos traçados por Eliseo Véron (1998): apresentador ventríloquo (gestualidade nula, postura corporal rígida e expressão facial extremamente comedida) e apresentador moderno ou meta-enunciador (explora o espaço do cenário, utiliza complexo sistema gestual). Devido à natureza extremada dos modelos trazidos por Véron, o Grupo Análise de Telejornais buscou características que estivessem mais próximas dos programas jornalísticos atuais, elaborando assim a classificação apresentador intérprete - gestos resumidos a expressões fisionômicas e movimentos breves com as mãos, exploração do cenário, porém, não de forma ampla. 
relação àquilo que noticiam. Sustentando a posição opinativa dos apresentadores, as imagens garantem autenticidade aos textos verbais. Percebemos, assim, que a objetividade é substituída pela possibilidade da audiência verificar as imagens dos acontecimentos, diante de apresentações sutilmente parciais.

Com relação ao enquadramento dos apresentadores, é comum aparecerem de corpo inteiro na tela, ou seja, em plano médio, o que se diferencia dos enquadramentos habituais dos telejornais, embora também aconteçam os enquadramentos em primeiro plano, que denotam maior proximidade do mediador com a audiência (usados quando um dos apresentadores interpela o público), e em plano americano, que distancia o apresentador da tela, de modo a ratificar os lugares de fala dos sujeitos da enunciação. O enquadramento em plano médio permite uma exploração maior do espaço do estúdio e dos próprios movimentos corporais, estando diretamente ligado à postura dos mediadores como intérpretes. Além disso, possibilita uma maior visibilidade do cenário, procurando destacar os recursos tecnológicos ali empreendidos, que colaboram na conformação de um contexto comunicativo envolto por um espetáculo.

Os jornalistas costumam dividir a apresentação de uma mesma matéria, conferindo dinamicidade na exposição dos fatos noticiados. É comum trocarem olhares e sorrisos, o que contribui para um ambiente comunicativo de familiaridade e descontração, reforçado pelo modo como os mediadores se referem à audiência: "você" - que garante uma suposta familiaridade com o receptor e funciona como meio de individualizá-lo.

A condução do Fantástico pelos apresentadores acontece num cenário que abusa dos recursos tecnológicos a serviço da televisão, resultando numa atmosfera visualmente moderna e futurista, que colabora para seu caráter de entretenimento. Com exceção de duas poltronas alaranjadas iguais, pouco utilizadas pelos apresentadores em suas variações de posicionamento, todo o restante é elaborado por computação gráfica. Isto evidencia a preocupação com o caráter de entretenimento do programa, além de exibir, ainda mais, sua habilidade em lidar com os recursos tecnológicos disponíveis. 
As cores predominantes do cenário são o azul e o dourado, que também refletem a intenção do programa em relacionar de maneira tênue jornalismo com entretenimento. O azul é a cor padrão dos principais telejornais nacionais, como o Jornal Nacional e o Jornal da Band. O dourado, por sua vez, revela brilho, chama a atenção dos olhos, garante requinte ao espaço que traz o "show da vida". Essa mesma combinação de cores é acompanhada na própria logomarca do programa, enfatizando a mesma relação. A computação gráfica adotada permite, ainda, a mudança constante da visualidade do cenário, permitindo tanto uma contextualização específica às matérias veiculadas, quanto dinamicidade e variedade ao programa de longa duração.

A tecnologia empregada, os trajes dos apresentadores, as cores e a variação das imagens fazem do cenário virtual um verdadeiro palco de variedades que, justamente por isso, permite a apresentação de matérias jornalísticas, quadros de humor, entrevistas, musicais. Ou seja, o cenário mesmo já dá pistas da proposta do programa e auxilia na contextualização comunicativa do receptor. A ideia de palco é reforçada, tanto pelo desempenho vocal de Cid Moreira, que anuncia as consideradas grandes atrações, como também pela própria fala dos mediadores, que incluem em seus textos frases como "Com vocês, os Caçadores de Mitos" (Zeca Camargo, dia 19 de março). "Senhoras e senhores, Odair José!” (Glória Maria, dia 26 de março).

\section{QUADROS FIXOS, PERSONAGENS FANTÁSTICOS E \\ AUTORREFLEXIVIDADE}

Com relação àquilo que é noticiado, verificamos a recorrência de três temáticas predominantes: a exploração de personagens fantásticos, a autorreflexividade e o cotidiano tratado, sobretudo, em quadros fixos por tempo irregular. O programa faz uso intensivo de tais elementos para configurar suas edições e definir seus critérios de noticiabilidade, que garantem a importância e a preferência conferidas aos assuntos, pelo Fantástico. São estes três temas que constituem os principais valores-notícia da revista eletrônica, nos indicando seu compromisso informativo com o entretenimento. 
Com relação aos personagens fantásticos, o programa trabalha histórias inusitadas de pessoas desconhecidas, explorando o fait-diver ${ }^{4}$ e a espetacularização. São abordagens em estilo dramático, voltadas à descrição e à narração de fatos, com ênfase nas pessoas envolvidas, como o brasileiro que se tornou um guarda-costas famoso nos Estados Unidos e o garoto americano autista que virou celebridade (26 de março). Essa opção configura-se em um critério de noticiabilidade um tanto particular do Fantástico, que dá indícios, pois, do seu modo de endereçamento. A configuração de critérios sobre o que é noticiável está diretamente relacionada ao tipo de jornalismo por ele praticado.

A autorreflexividade, por sua vez, é uma intertextualidade através da qual o programa pauta a si mesmo e ao restante da grade da emissora, refletindo ele próprio e a Rede Globo nas matérias veiculadas. Segundo Elizabeth Bastos Duarte, "[...] a auto-reflexividade é um procedimento da ordem da incidência", que implica a presença de um sujeito "que faça de si próprio objeto do discurso por ele mesmo produzido". (DUARTE, 2004, p. 91) Desta forma, o Fantástico volta-se a todo o momento para si e para a Globo, numa autorreferência que demanda do telespectador o conhecimento sobre a grade da emissora, ao mesmo tempo em que o atualiza quanto aos programas da rede, convocando-o à acompanhá-los. Alguns exemplos: canção inédita de Tom Jobim, que iria embalar um dos personagens da novela Belíssima (26 de março); ensaio fotográfico de Cláudia Raia e Reinaldo Gianechini, par romântico também de Belíssima, e a nova série de reportagens especiais do Jornal Nacional sobre os jogadores da seleção brasileira (02 de abril).

Temos, ainda, a temática do cotidiano fortemente presente no produto analisado. Aqui, entendemos por cotidiano

[...] o ambiente espaço-temporal no qual as experiências que vivenciamos são próximas a nós tanto no espaço das nossas relações comuns (nossa casa, nosso trabalho, a rua pela qual costumeiramente nos deslocamos etc.) quanto no tempo em que fazemos as ações. (FRANCISCATO, 2003, p. 67)

4 Fatos sensacionais, de forte apelo emotivo. (GUERRA, 2003, p. 35) 
A opção por tratar deste tipo de assunto indica o investimento da revista eletrônica em tentar estabelecer com a audiência uma relação de proximidade, construindo, dentro de seus conteúdos, espaços para a identificação do público com os mesmos.

Para abordar este tema, o Fantástico opta por formatá-lo, normalmente, em quadros fixos por tempo irregular, que obedecem a um sistema de revezamento temporal aleatório - apesar de serem apresentados aos telespectadores quando estreiam, saem e retornam ao programa sem avisos prévios à audiência. Isto garante à revista eletrônica uma novidade contínua, baseada em quadros intercalados que colaboram na estruturação das edições em linguagem aproximada ao videoclipe, com o uso extenso de recursos visuais e sonoros, enfatizando, mais uma vez, a utilização de tais recursos com destreza pelo Fantástico e a centralidade dessa utilização para a configuração de seu estilo, reforçando seu contexto comunicativo de entretenimento.

A recorrência aos quadros, aliada à promessa da revista em misturar jornalismo e entretenimento, abrindo possibilidades de veiculação de temas variados, habilita o Fantástico como um espaço para programas- pilotos que, antes de serem efetivados ou não na grade, aparecem sob a forma de quadros na revista eletrônica. Aqui, o programa opera com valores-notícia potenciais, testando expectativas sociais e verificando a possibilidade de inclusão de novos atributos em sua seleção de conteúdos e, portanto, em sua redefinição sobre o jornalismo proposto. $\mathrm{Na}$ amostra, dois quadros funcionaram como testes para futuras apostas da Rede Globo: Minha Periferia e Profissão Repórter.

Apresentado por Regina Casé, o Minha Periferia foi a prévia do programa Central da Periferia, veiculado mensalmente nas tardes de sábado, durante o período de análise. Famosa por sua atuação no TV Pirata e pela apresentação dos programas Brasil Legal e Muvuca, onde entrevistava pessoas comuns num clima de descontração e familiaridade, Regina Casé transporta, ao quadro, esse mesmo traço de apresentação. No Minha Periferia, leva artistas famosos, que nasceram em bairros de baixa renda, de volta ao seu local de nascimento, ao passo que mostra o cotidiano das pessoas que vivem nestas localidades, explorando as tendências culturais 
do bairro. Como o Central da Periferia no período analisado foi transmitido mensalmente, quebrando o hábito de audiência do público, o quadro dominical reforçava a divulgação do programa.

Nele, a relação entre jornalismo e entretenimento também se faz presente. Quando o quadro entra em cena, a seguinte frase aparece no canto esquerdo da tela: "Regina Casé em", e logo à direita do vídeo a logomarca e o título Minha Periferia. A simples frase revela que a apresentadora representa papel fundamental no quadro e que a cada semana ela vivencia "novas aventuras". O próprio clichê "Fulano de tal em" é popularizado entre os telespectadores e desperta a familiaridade deles com relação ao personagem principal do quadro, Regina Casé. A estampa camuflada das roupas por ela utilizadas também indica esse caráter de aventura. Ao lado de toda essa espetacularização, a atriz faz uso de umas das ferramentas amplamente empregadas no jornalismo: a entrevista. Apesar de não ser de uso exclusivo do jornalismo e de não ter sido criada pela atividade, a entrevista é uma de suas marcas centrais no exercício da apuração das notícias e, no quadro, é o recurso acionado para caracterizá-lo jornalisticamente. A presença da apresentadora no local onde se desenvolve a matéria também pode ser considerada uma tentativa de gancho com o jornalismo televisivo brasileiro, já que a presença do repórter nos locais dos fatos é, também, uma marca registrada que procura enfatizar aos olhos do receptor a verdade e a objetividade da busca da informação.

O Profissão Repórter, por sua vez, estreou dia 07 de maio com a proposta de mostrar os bastidores do cotidiano da produção de notícias. Revelar os bastidores é uma proposta um tanto quanto semelhante à de programas como Vídeo Show (bastidores da televisão) e Big Brother Brasil (bastidores da vida privada). Caco Barcellos é o elemento jornalístico principal do quadro. Autor de livros famosos de jornalismo investigativo (Rota 66 e Abusado), ele empresta ao quadro sua credibilidade e seu compromisso com a verdade, firmado através de suas publicações, de premiações renomadas (Jabuti e Vladimir Herzog) e de sua atuação no jornalismo televisivo. Perseguido e ameaçado por conta de Rota 66, o jornalista permaneceu afastado do país como correspondente internacional da Globo em 
Londres, ficando conhecido, por isso, pelos seus trabalhos de apuração e investigação. É esta trajetória que o jornalista leva para o quadro.

Vejamos, agora, outros quadros que apareceram no corpus considerado, a fim de evidenciar a presença do cotidiano no programa e o "infotenimento" oferecido.

\section{Caçadores de mitos}

Original do canal fechado Discovery Channel (voltado para o entretenimento), o quadro é retransmitido pelo Fantástico, que introduz trechos gravados pelo próprio programa, retirando-o da condição de mera tradução. O ator Lúcio Mauro Filho é o apresentador e o responsável pela dublagem das falas dos dois protagonistas do quadro, que são os caçadores de mitos. A cada edição, a dupla escolhe uma crença popular para afirmá-la como verdadeira ou falsa. Com microfone em punho, Mauro Filho vai às ruas, colhe depoimentos sobre a veracidade ou não da história apresentada e grava cenas nos locais onde os tais mitos podem acontecer. Notamos uma tentativa de "abrasileirar" o quadro que, elaborado num outro contexto cultural, não traz crenças partilhadas de maneira universal. Além disso, o microfone, os depoimentos e a presença do ator no local onde podem acontecer as situações exploradas, são elementos muito arraigados no jornalismo brasileiro, sobretudo, no televisivo. Podemos interpretá-los como uma tentativa de hibridização do quadro, que partilha da sobreposição entre jornalismo e entretenimento. A escolha de um ator para exercer as funções de repórter, no quadro, deixa clara esta tentativa. A própria busca da verdade, que consiste no objetivo do Caçadores de Mitos, remete aos princípios primordiais do jornalismo.

\section{SITCOM.BR ${ }^{5}$}

Este quadro traz atores da Globo interpretando breves textos ficcionais, inspirados no cotidiano dos brasileiros, o que nos leva a crer que o "br” significa “do Brasil” ou "brasileiras”. A exploração de situações pe-

5 Os programas sob o formato de sitcom, estilo mais enraizado na cultura americana, trazem o humor e a teledramaturgia em sua configuração, apresentando, em situações cômicas, os costumes dos cidadãos comuns (SOUZA, 2004, p. 135) - como acontece no quadro em questão. 
las quais, supostamente, todos já passaram em algum momento, revela a tentativa de posicionar o telespectador dentro do quadro e gerar uma identificação do mesmo com aquilo que é transmitido. Em cada edição, traz um texto escrito e dirigido por profissionais diferentes, o que garante a variabilidade do quadro, tanto nas histórias como em suas formas de contá-las. Engrossando seu caráter de entreter, temos a participação de atores e a própria formatação do quadro: um misto de teleteatro e cinema, onde a interpretação em cenários limitados é o foco central da câmera. Constantemente, os atores olham diretamente para a câmera, para o telespectador, o interpelando pelo olhar como fazem os apresentadores, contribuindo para um contexto comunicativo dialógico. O quadro reflete a utilização da linguagem audiovisual pelo programa, mostrando sua capacidade em variar os recursos disponíveis.

\section{Repórter por 1 dia}

Neste quadro, a hibridização entre jornalismo e entretenimento mostra-se de maneira mais explícita. Nele, um ator da Rede Globo é convidado a exercer as funções de repórter, apresentando uma matéria normalmente relacionada a personagens atuais ou já interpretados. Os atores utilizam microfone, entrevistam fontes, realizam passagem e, ao final, se apresentam e informam o nome do quadro, modo semelhante ao que os repórteres de telejornais finalizam suas matérias: "Mariana Ximemes, repórter por 1 dia, para o Fantástico". Esses elementos fazem referência direta ao telejornalismo, transportando certa credibilidade ao que está sendo veiculado por atores e não por jornalistas. As temáticas e os atores escolhidos revelam, mais uma vez, a aposta do Fantástico na autorreferência com relação à grade de programação da emissora.

\section{Tá limpo}

Conhecido como Dr. Bactéria, o biomédico Roberto Figueiredo explica sobre germes e bactérias, os locais onde são encontrados e os cuidados que devem ser tomados para que se evitem contaminações. Aqui, o Fantástico procura reivindicar para si um dos deveres principais que regem a conduta, ao menos teoricamente, dos jornalistas: a de cães de guarda da 
sociedade. Mostrando os locais que vendem alimentos de maneira inapropriada e auxiliando os receptores a tomarem atitudes corretas para seu bem-estar e saúde, o quadro procura cumprir a função de vigilância social, informando a sociedade quanto às irregularidades sanitárias praticadas.

\section{Teste do INMETRO}

Neste quadro, o Fantástico segue a mesma linha do explicado acima, reivindicando a postura de vigilante social. A cada edição, um tipo de produto é escolhido e as diversas marcas que o fabricam têm a qualidade de produção testada pelo Inmetro - Instituto Nacional de Metrologia, Normalização e Qualidade Industrial. Além da credibilidade do Instituto, o quadro traz depoimentos informativos de profissionais gabaritados sobre o produto analisado. As marcas reprovadas no teste, de acordo com o quadro, são procuradas para dar explicações, o que reflete a tentativa do mesmo em se mostrar justo e democrático, respeitando o direito de resposta e dando voz ao outro lado da questão.

\section{TEMPORALIDADES E FORMATOS NO FANTÁSTICO}

Os quadros, matérias de autorreflexividade e exploração de personagens fantásticos, apesar de recorrentes e de ocuparem grande parte do espaço do Fantástico, não constituem a totalidade daquilo que é veiculado nas 2h30min de duração da revista eletrônica. Charge, entrevistas, entradas ao vivo, pautas frias, matérias de desdobramentos da semana, entre outras, também compõem o programa, que aposta tanto na variedade temática quanto na variedade de formatos de apresentação de seus conteúdos.

Veiculado nas noites de domingo, o Fantástico trabalha a maioria do seu conteúdo com um conceito de atualidade distinto daquele predominante nos telejornais. No ar de segunda a sábado, os noticiários trazem, em grande parte, informações que aconteceram no dia mesmo de suas exibições, com um sentido de atualidade estreitamente ligado ao tempo presente dos fatos. Já no Fantástico, a atualidade é considerada, muitas vezes, na perspectiva da revelação pública. O sentido de novidade, aqui, 
não é presentificado como nos jornais televisivos, mas baseado no ineditismo e na exclusividade. É esse sentido temporal que se aplica à maioria das entrevistas trazidas.

Outra maneira encontrada pelo programa semanal para lidar com a atualidade em seu conteúdo é a atemporalidade de pautas, que consiste na produção de matérias que podem ser exibidas em quaisquer edições, sem o risco permanente de desatualização. Esse tipo de matéria é conhecido pelos jornalistas como pautas frias ou matérias de gaveta, ou seja, não necessitam ser veiculadas hoje para fazer sentido e nem tampouco tratam de assuntos inéditos. Os quadros fixos, por exemplo, e a maioria das matérias referentes a personagens fantásticos são atemporais.

A atualidade também é explorada através de entrevistas e matérias relacionadas aos acontecimentos da semana de exibição do programa. Oferecendo desdobramentos dos assuntos que foram notícias, o Fantástico mostra-se conectado aos eventos do país e do mundo, não abandonando o sentido de atualidade ligado ao presente, mesmo que este presente, na verdade, seja o passado recente. A entrevista com Odair José, realizada no dia 23 de março, nos serve de exemplo. Um CD em homenagem ao cantor havia sido lançado naquela semana e o programa aproveitou o gancho para entrevistá-lo.

Já com relação às principais notícias do domingo, o Fantástico apresenta um resumo delas em pequenos quadros espalhados pelos blocos do programa, intitulados É Notícia. Esses breves quadros, presentes em todas as edições analisadas, trazem, na sua maioria, notas narradas pelos apresentadores do programa sobre os principais acontecimentos do dia. Uma opção da revista eletrônica para não se eximir de trabalhar com o referencial de temporalidade ligado ao seu dia de exibição, como fazem os telejornais.

O sentido de atualidade referente ao tempo presente acontece, ainda, com as entradas ao vivo da repórter Patrícia Poeta, de Nova Iorque. O "ao vivo" remete à temporalidade simultânea, ao agora, ao neste momento. No jornalismo, o tempo real é buscado como meio de suprimir o tempo do acontecimento do tempo de seu relato, na tentativa de informar o fato imediatamente ao receptor. Em estúdio próprio do Fantástico, no exte- 
rior, Poeta apresenta notícias realizadas nos Estados Unidos ou referentes ao país norte-americano. Aqui, notamos a tentativa do programa em revelar sua capacidade de cobertura mundial, além do seu poderio técnico. Com os lugares de fala transferidos, a correspondente internacional passa a comandar a apresentação do programa, diretamente do local onde as notícias a serem transmitidas foram produzidas. Portanto, mais uma vez temos a importância conferida ao repórter no local do acontecimento, o que, aliado às imagens mostradas, dá o tom de verdade e objetividade das matérias.

\section{CONSIDERAÇÕES FINAIS}

Trabalhando com as preponderâncias observadas, vemos que o Fantástico - é bom notar as pistas imbuídas no nome mesmo do programa, que já informa o estilo inusitado e espetacular de lidar com os assuntos - estabelece um pacto hibridizado sobre o papel do jornalismo que firma com sua audiência, voltado tanto para a conversação social quanto para o entretenimento. Seu caráter informativo de relatar os acontecimentos é conformado com o objetivo de alimentar a conversação cotidiana, com vistas à formação da opinião pública sobre a realidade social. Aqui, entram os elementos que promovem a condução interpretativa do telespectador, dentro dos conteúdos transmitidos, como a postura dos mediadores, a performance vocal de Cid Moreira e a objetividade substituída pela possibilidade de verificação dos fatos.

Em função da variabilidade de formatos trazidos e da variedade do conteúdo apresentado, dentro de um contexto comunicativo dialógico, marcado pela descontração e leveza, o compromisso com o entretenimento é constantemente verificado. A ampla utilização de recursos da linguagem audiovisual, que empreendem um ritmo dinâmico à estruturação da revista, o modo como se apresenta o cenário, a presença de Eva Byte, a própria vinheta do programa, enfim, colaboram na construção desse pacto, marcado, também, pela exploração de fait-divers. Aliás, a diversidade de apresentação do Fantástico revelou-se como a característica principal do gênero revista eletrônica, incidindo diretamente na configuração do seu estilo particular. 
Assim, procuramos mostrar em nosso percurso analítico a articulação entre jornalismo e entretenimento, que resultou, pois, num pacto híbrido, condizente com a proposta central da revista em oferecer "infotenimento". Esse "showrnalismo", configurado, sobretudo, na variabilidade de formatos que primam pelos recursos audiovisuais, busca também operar com uma gama diversificada de temas, onde o cotidiano espetacularizado - o "show da vida" - se mostra a linha de costura desse mosaico de atrações. É na tentativa de dar conta das mais diferentes situações do dia a dia, sob enfoques variados, que o Fantástico segue, então, o objetivo de abarcar uma ampla e variada audiência nacional.

\section{REFERÊNCIAS}

ARBEX JR., José. Showrnalismo, a notícia como espetáculo. São Paulo: Casa Amarela, 2002.

DUARTE, Elizabeth Bastos. Televisão: ensaios metodológicos. Porto Alegre: Sulina, 2004.

FRANCISCATO, Carlos Eduardo. A atualidade no jornalismo: bases para sua delimitação teórica. 2003. Tese (Doutorado em Comunicação e Cultura Contemporâneas) - Faculdade de Comunicação, Universidade Federal da Bahia, Salvador.

GOMES, Itania Maria Mota et. al. Quem o Jornal do SBT pensa que somos? Modos de endereçamento no telejornalismo show. Revista FAMECOS, Porto Alegre, n. 25, p. 85-98, dezembro 2004. GUERRA, Josenildo Luiz. O percurso interpretativo na produção da notícia. 2004. Tese (Doutorado em Comunicação e Cultura Contemporâneas) - Faculdade de Comunicação, Universidade Federal da Bahia. Salvador.

JOST, François. Seis lições sobre televisão. Porto Alegre: Sulina, 2004.

MAIA, Jussara Peixoto. Jornalismo temático televisivo no Brasil. 2005. Dissertação (Mestrado em Comunicação e Cultura 
Contemporâneas) - Faculdade de Comunicação, Universidade Federal da Bahia. Salvador.

SOUZA, José Carlos Aronchi de. Gêneros e formatos na televisão brasileira. São Paulo: Summus, 2004.

VERON, Eliseo. La semiosis sociale. Barcelona: Editorial Gedisa, 1998. 


\section{Sobre os autores}

DANNILO DUARTE OLIVEIRA é mestre em Comunicação e Cultura Contemporâneas pela Universidade Federal da Bahia (UFBA) e professor assistente do curso de Comunicação Social da Universidade Estadual do Sudoeste da Bahia (UESB). Coordena o grupo de pesquisa em Telejornalismo e Novas Tecnologias. O artigo aqui publicado é resultado de sua dissertação de mestrado.

http: / /lattes.cnpq.br/7216357926129338

FERNANDA MAURICIO DA SILVA é doutora em Comunicação e Cultura Contemporâneas pela Universidade Federal da Bahia (UFBA). Possui graduação em Jornalismo e mestrado em Comunicação e Cultura Contemporâneas também pela UFBA. É pesquisadora associada do Grupo de Pesquisa em Análise de Telejornalismo através de bolsa de pós-doutorado (PNPD/CNPq) . O artigo aqui publicado é resultado de sua tese de doutorado.

http:/ / lattes.cnpq.br/7512426170492329

ITANIA MARIA MOTA GOMES coordena o Grupo de Pesquisa em Análise de Telejornalismo (www.telejornalismo.facom.ufba.br). É professora do Programa de Pós-Graduação em Comunicação e Cultura Contemporâneas/UFBA, pesquisadora do CNPq e presidente da Associação Nacional dos Programas de Pós-Graduação em Comunicação - Compós (2009/2011). É autora do livro Efeito e Recepção. A interpretação do processo receptivo em duas tradições de investigação sobre os media. Rio de Janeiro: E-Papers, 2004.

http:/ /lattes.cnpq.br/1249313747086140

JANIRA TRÍPODI BORJA é mestra em Relações Internacionais na Universidade de Brasília (UNB). Possui graduação em Comunicação com habilitação em Produção em Comunicação e Cultura pela Universidade 
Federal da Bahia (UFBA). O artigo aqui publicado é resultado de sua monografia de conclusão de curso. http: / / lattes.cnpq.br/1302374719866717

JULIANA FREIRE GUTMANN é doutoranda do Programa de Pós-Graduação em Comunicação e Cultura Contemporâneas pela Universidade Federal da Bahia (UFBA) e professora do curso de Jornalismo da Faculdade Social da Bahia. É pesquisadora do Grupo de Pesquisa Análise de Telejornalismo (www.telejornalismo.facom.ufba.br). O artigo aqui publicado é resultado de sua dissertação de mestrado. http:/ / lattes.cnpq.br/1713091767353588

JUSSARA MAIA é doutoranda do Programa de Pós-Graduação em Comunicação e Cultura Contemporâneas pela Universidade Federal da Bahia (UFBA) e professora do curso de Jornalismo da Faculdade Social da Bahia. É pesquisadora do Grupo de Pesquisa Análise de Telejornalismo (www.telejornalismo.facom.ufba.br). O artigo aqui publicado é resultado de sua dissertação de mestrado. http: / / lattes.cnpq.br/4258151127958330

LUANA GOMES é jornalista formada pela Universidade Federal da Bahia (UFBA) e pós-graduanda em Convergência Midiática pela Faculdade Social da Bahia. O artigo aqui publicado é resultado de sua monografia de conclusão de curso. http: / / lattes.cnpq.br/7178417351021872

MARÍLIA HUGHES GUERREIRO COSTA é mestre em Comunicação e Cultura Contemporâneas pela Universidade Federal da Bahia (UFBA) e graduada em Psicologia pela mesma instituição. Curadora da mostra competitiva de filmes do Panorama Internacional Coisa de Cinema. Dirigiu os curtas de ficção "Carreto" e "Nego Fugido" e os documentários “O Guarani”, “Imagens do Xaréu” e "Pelores”. O artigo aqui publicado é resultado de sua dissertação de mestrado. http: / / lattes.cnpq.br/0848087975545837

MIRELLA SANTOS FREITAS é graduada em relações públicas pela Universidade Salvador (UNIFACS) e mestre em Comunicação e Cultura Con- 
temporâneas pela Universidade Federal da Bahia (UFBA). O artigo aqui publicado é resultado de sua dissertação de mestrado.

http:/ /lattes.cnpq.br/1749689036107106

THIAGO EMANOEL FERREIRA DOS SANTOS é jornalista e atua como repórter do site Política Livre. Formou-se em Comunicação pela Universidade Federal da Bahia (UFBA) em 2009. É bolsista de apoio técnico/ CNPq do Grupo de Pesquisa em Análise de Telejornalismo (www.telejornalismo.facom.ufba.br). O artigo aqui publicado é resultado de sua monografia de conclusão de curso.

http: / / lattes.cnpq.br/2929683699605499

VALÉRIA VILAS BÔAS ARAÚJO formou-se em Comunicação Social pela Universidade Federal da Bahia (UFBA) em 2008. É mestranda em Comunicação e Cultura Contemporâneas também pela UFBA e pesquisadora do Grupo de Pesquisa Análise de Telejornalismo (www.telejornalismo.facom.ufba.br). O artigo aqui publicado é resultado de sua monografia de conclusão de curso.

http://lattes.cnpq.br/9201685938383434 


\begin{tabular}{r|l} 
Formato & COLOFÃO \\
Tipografia & Leitura $23 \mathrm{~cm}$ \\
Papel & $\begin{array}{l}\text { Alcalino } 75 \mathrm{~g} / \mathrm{m}^{2}(\mathrm{miolo}) \\
\left.\text { Cartão Supremo } 300 \mathrm{~g} / \mathrm{m}^{2} \text { (capa }\right)\end{array}$ \\
Impressão & $\begin{array}{l}\text { Setor de Reprografia da EDUFBA } \\
\text { Capa e Acabamento }\end{array}$ \\
Tigragem & 500
\end{tabular}

